\title{
ESTÉTICA Y BIOARTE
}

PASAJES DE LO MODERNO A LO CONTEMPORÁNEO EN TORNO A LAS NOCIONES DE OBRA, ARTISTA, ESPECTADOR Y EXPERIENCIA

Tesista:

MAG. NATALIA MATEWECKI

Directora:

DRA. ANALÍA MELAMED

UNIVERSIDAD NACIONAL DE LA PLATA

FACULTAD DE BELLAS ARTES DOCTORADO EN ARTES LA PLATA, ARGENTINA 
0. Algunas palabras para comenzar ...................................... 4

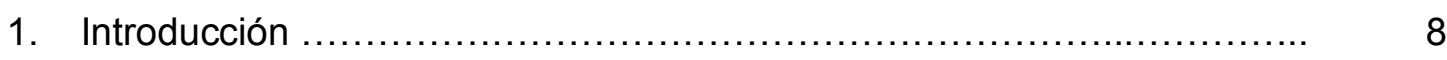

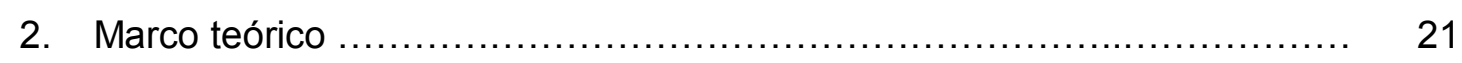

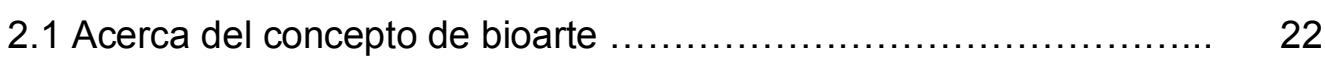

2.2. Ciencia, arte, filosofía. Hibridaciones, cruces, convergencias ........ 27

2.3. Acerca de la discusión estética sobre el bioarte .................... 39

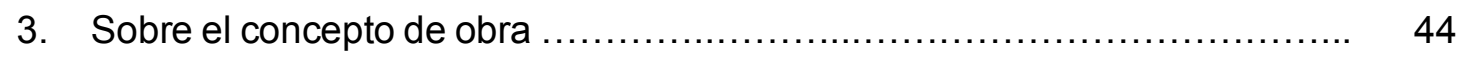

3.1 Obras modernas y contemporáneas ........................... 45

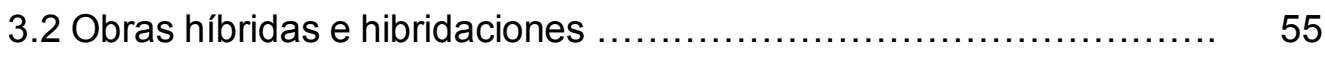

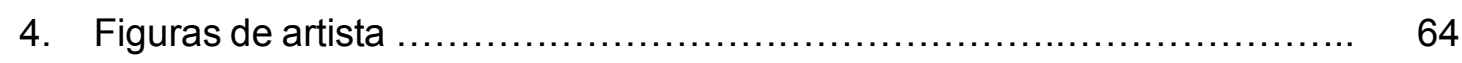

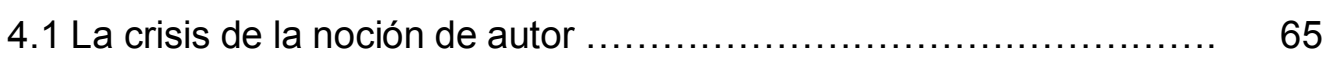

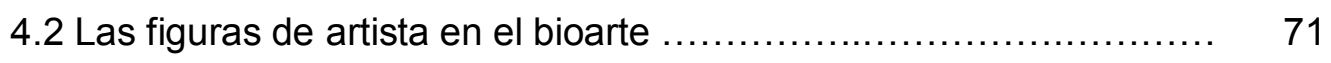

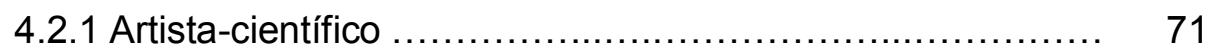

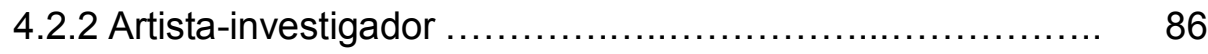

4.2.3 Artista-divulgador .................................... 94

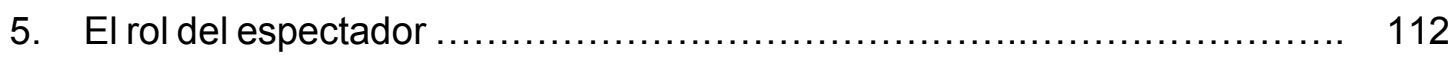

5.1 Espectador y bioarte. Roles, relaciones, negociaciones ............ 113

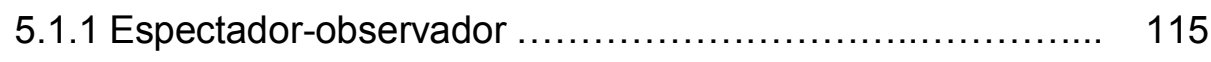

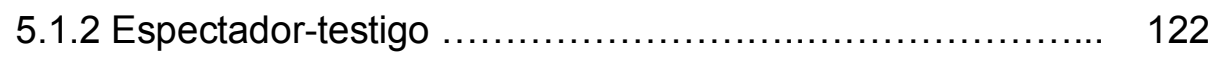

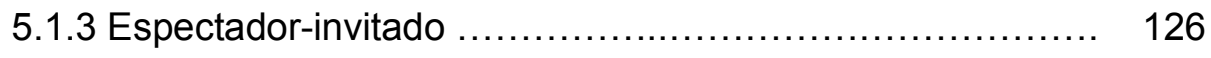

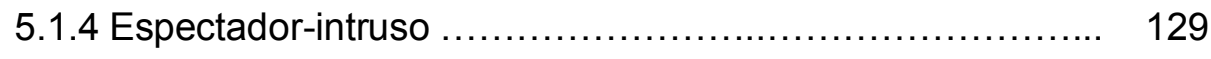




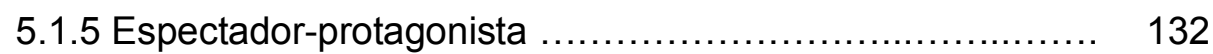

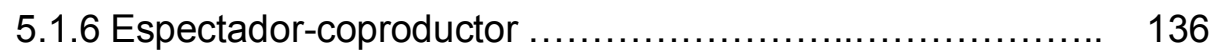

6. Bioarte como síntesis de la experiencia ................................... 144

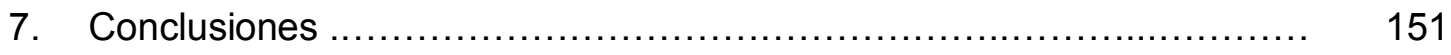

8. Bibliografía .................................................. 160

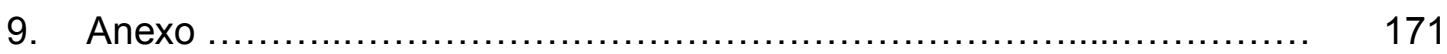


0. ALGUNAS PALABRAS PARA COMENZAR 
Hace unos años, un grupo de becarios de la universidad viajamos a un encuentro de jóvenes investigadores para exponer lo que cada uno estaba investigando en ese momento. Debido a una serie de infortunios el megaencuentro científico resultó ser un tanto caótico ya que no pudimos acceder a dar conferencias, nuestros trabajos nunca aparecieron en el libro de actas y sólo pudimos conseguir quedar ubicados en la sección "pósters".

Los pósters estaban separados por áreas (Producción Cultural, Biofísica, Ingeniería Agrícola, etc.) y debían ser evaluados por tres jueces idóneos. Todos esperábamos ansiosos el día de la evaluación para poder contar lo que hacíamos y que el tan largo viaje académico se justificara.

Miércoles a las nueve y media de la mañana fue el horario establecido por los organizadores para la evaluación. Diez minutos antes del horario pautado me encontraba en el aula de Producción Cultural esperando a los evaluadores. No éramos muchos en la sala pero cada uno esperaba al lado de su póster. Con cada persona que entraba pensaba si sería el evaluador, pero siempre terminaba siendo otro investigador del área de Producción Cultural o de otras áreas que recorrían las aulas mirando los pósters ajenos a sus disciplinas. Los minutos pasaban y no entraba ningún evaluador, allí me enteré que uno de ellos había pasado más temprano. Esperando al siguiente evaluador decidí salir del recinto y visitar otras áreas.

Luego de dos horas ingresó a nuestro recinto una señora con unos papeles en la mano, parecía ser evaluadora. Rápidamente entré y me ubiqué al lado de mi póster. 
La evaluadora se posaba frente a cada póster en silencio sin preguntar ni mirar al joven investigador. Cuando llegó mi turno le pregunté si quería que le comentara el trabajo, "No es necesario" me respondió fríamente. Anotó unas cosas en una planilla y se fue. Me quedé esperando al tercer evaluador que nunca apareció. Ya pasado el mediodía decidí ir a almorzar con el resto del grupo y después salir a recorrer la ciudad para olvidarme de ese fallido día.

A la vuelta del viaje la sensación era extraña, el tan ansiado intercambio de conocimientos entre investigadores no se produjo, sólo me quedaba un certificado como recuerdo de mi participación en aquel encuentro.

Sin embargo, unos días más tarde al recibir un e-mail la desazón desapareció:

----- Original Message -----

From:e.r.

To:Natalia Matewecki

Sent: Monday, October 31, 2011 11:18 AM

Subject: poster bioarte de AUGM

Hola Natalia, no nos conocemos, pero vi tu póster y como no logré ubicarte en el aula para charlar, hoy te escribo. Yo estaba en el núcleo de agroalimentos porque soy licenciada en química, pero anduve mirando otras áreas, como producción artística. No había escuchado nunca hablar de bioarte y leí atentamente tu trabajo,por lo que quería hacerte una crítica constructiva.

En la sección "discusión" hablás de seres vivos, y de seres semivivos. No existen seres semivivos, por lo que es un error clasificar a cultivos celulares, tisulares y virales como semivivos. Sería bueno que si trabajás en bioarte, algo interdisciplinar, y desconocés ciertas cosas, consultaras gente de distintas disciplinas, porque corrés estos riesgos.

Espero te sirva mi aporte, saludos.

E.

Curiosamente esta crítica hacia mi trabajo me alegró enormemente. En ese momento me di cuenta que aquel viaje había logrado tener algún sentido, alguien se había interesado por mi investigación y había encontrado un punto de inflexión conflictivo y provocador dado por la ambigüedad que planteaba la obra de bioarte. Mi respuesta no 
tardó en llegar y brevemente traté de esbozar una suerte de explicación a los cuestionamientos realizados. No obstante, aquella devolución requería de la explicitación de un marco teórico que en pocas líneas no podía desarrollar, necesitaba una mayor extensión de escritura para poder hacerlo y que mi postura quedase clara y bien justificada. Podría decirse que ese incidente fue el punto de partida de la presente tesis. 


\section{INTRODUCCIÓN}


Luego de varios años de estudio sobre lo que sucedía en el "interior" del bioarte, -sus propiedades constitutivas, aquello que definía a una obra como parte de este géneroencontramos que las preguntas y comentarios de colegas, alumnos y público en general estaban dirigidas principalmente a resaltar un único aspecto: la novedad del género, y con ello, el carácter transgresor y rupturista. Ese interés no puede ser separado de un contexto general de crisis de fundamentos del arte.

En efecto, es una consecuencia de estas propuestas sin duda provocativas del bioarte -así como también las del conceptualismo, videoarte, arte digital, entre otras- el hecho de que resulte necesario repensar la teoría estética tradicional y sus principales categorías: obra de arte, belleza, autor, experiencia estética, receptor. Al mismo tiempo, la estetización de la vida social y política desvanece aún más las fronteras de lo artístico por lo que encontramos serias dificultades de definición y de identificación del campo artístico. Según el crítico Harold Rosenberg, en las últimas décadas del siglo XX, ocurren simultáneamente un proceso de desestetización del objeto artístico y una desdefinición del arte $^{1}$. Es así que proliferan las declaraciones sobre la declinación o muerte del arte. Por ejemplo, Gianni Vattimo, en una línea nietzscheana y heideggeriana, diagnostica la muerte del arte como consecuencia principalmente de la mencionada estetización de la existencia: "La muerte del arte significa dos cosas: en un sentido fuerte y utópico, el fin del arte como hecho específico y separado del resto de la experiencia en una existencia rescatada y reintegrada; en un sentido débil o real,

\footnotetext{
${ }^{1}$ Michaud, Y. (2007). El arte en estado gaseoso. Ensayo sobre el triunfo de la estética. México: Fondo de Cultura Económica.
} 
la estetización como extensión del dominio de los medios de comunicación de masas." ${ }^{2}$ Desde una perspectiva analítica Arthur Danto, a la luz de la imposibilidad de discernir perceptualmente una obra de arte de un objeto de uso cotidiano en las obras del pop art, en particular de Warhol, plantea "el inevitable vacío de las definiciones tradicionales de arte" ${ }^{3}$, de lo que se sigue el fin de las narrativas sobre el arte y con ello el fin de la historia del arte. Por su parte Yves Michaud en El arte en estado gaseoso sostiene que en la época actual de estetización generalizada se verifica una suerte de volatilización de los objetos artísticos. En un contexto donde lo artístico se expande y colorea todo, del mundo del diseño y la publicidad, a los medios de comunicación y las nuevas tecnologías, las obras de arte, dice, han sido reemplazadas por dispositivos y procedimientos que funcionarían como obras y que a su vez,

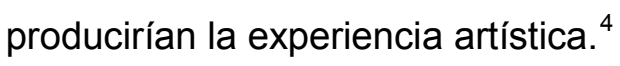

Los cuestionamientos hacia el bioarte, en el marco de la crisis de la teoría estética dieron lugar a interrogantes a los que esta tesis pretende responder, si bien de manera no concluyente. ¿Realmente el bioarte es una práctica novedosa? ¿Rompe con toda la tradición artística? ¿Pone en crisis las categorías estéticas? Si bien no podemos dar respuestas terminantes afirmativas o negativas, proponemos algunos intentos de respuesta ateniéndonos a la especificidad de la práctica artística y la producción del bioarte.

En cuanto a un carácter novedoso del bioarte, podría encontrarse en la relación estrecha que establece con la ciencia. Podríamos decir que éste hace un uso poético del lenguaje y la práctica científica, sin embargo también lo hacían los pintores del Renacimiento cuando utilizaban fórmulas matemáticas para componer sus obras o,

\footnotetext{
${ }^{2}$ Vattimo, G. (1990). "Muerte o crepúsculo del arte". El fin de la modernidad. Nihilismo y hermeneútica en la cultura posmoderna. Barcelona: Gedisa.

${ }^{3}$ Danto, A. (2002). La transfiguración del lugar común. Una filosofía del arte. Barcelona: Paidós.

${ }^{4}$ Michaud, Y. Op. cit.
} 
más cerca en el tiempo, los artistas del Op Art cuando apelaban a ciertos conocimientos de la física para desarrollar sus trabajos. No obstante, es posible hallar un carácter de novedad en que se basa en una ciencia relativamente joven. La biotecnología no pudo existir antes de que fuera descubierta la estructura del ADN en 1953, y más aún, no se puede hablar de obras de bioarte antes de finales de la década del setenta que es cuando se fundan las ciencias biotecnológicas. Por consiguiente, obras como el Fitotrón (1972) de Luis Benedit o las Analogías (desde 1970) de Victor Grippo no pueden ser consideradas bioarte ya que temporalmente no es posible incluirlas dentro de este género, pero sí pueden ser analizadas como sus antecedentes. Estrictamente el carácter de novedad consistiría en una particular perspectiva estética sobre las ciencias biotecnológicas dado que estas suponen una concepción de ciencia interdisciplinaria y en estrecha vinculación con la tecnología, la sistematización científica de conocimientos es inseparable de un conjunto de prácticas y de dispositivos técnicos. Asimismo su lenguaje comprende un amplio espectro de lenguajes, desde el lenguaje natural hasta los más diversos lenguajes artificiales. En ese sentido se podría afirmar que el lenguaje del bioarte está constituido por esos lenguajes, prácticas y dispositivos, que dejan de ser tomados en su carácter meramente instrumental o cognoscitivo para ser investidos de un sentido poético.

En cuanto a si esto significa una ruptura con todo el arte anterior, nuestra hipótesis es que no, pero sí que tiene el efecto de desestabilizar o provocar si se lo evalúa a la luz de criterios estéticos más o menos establecidos. Sostenemos que el bioarte profundiza la crisis acerca de los conceptos de creación, obra, artista y espectador, que con variaciones proceden fundamentalmente de la modernidad, y que atañe no solo al bioarte sino a aquellas producciones que se enmarcan dentro del arte contemporáneo. 
De modo tal que, como se mencionó al comienzo, tensiona los límites del arte, del mismo modo que la mayoría de las producciones artísticas contemporáneas.

Dar cuenta de que el bioarte pone en crisis la tradición artística tampoco resuelve el problema porque ¿en qué sentido se puede decir que el bioarte cuestiona o transforma categorías estéticas tales como las de obra, artista y espectador?

Esto nos lleva a intentar establecer desde qué perspectiva cada una de estas categorías resulta cuestionada: ¿El surgimiento del bioarte supone una ruptura con la dimensión productiva artística de la modernidad? ¿Qué estatuto adquiere el concepto de "autotransformación" de la obra en el marco de las condiciones de producción por parte del artista? ¿Están previstas las autotransformaciones de la obra como parte de la dimensión productiva y el hecho estético? Por su parte, desde la perspectiva de la noción de artista es posible preguntar ¿Cuáles son los aspectos singulares del rol que asume el artista en el bioarte? ¿El artista se autodefine o identifica con una identidad específica que vincula arte y ciencia? ¿El artista está previsto en la obra misma? En cuanto al receptor de la obra de bioarte, ¿Requiere un espectador con competencias específicas y en ese sentido introduce un nuevo concepto de recepción artística aún no desarrollado por la reflexión estética? ¿Es un receptor pasivo, activo, expectante de la obra? ¿Prevé un receptor "especializado"?

Como hipótesis de este trabajo se plantea: a) la existencia de un quiebre con la permanencia-continuidad de la obra tradicional a través de obras que presentan un ciclo de vida mutable y finito; b)la figura de artista -que proviene fundamentalmente del romanticismo- entra en tensión ante la emergencia de otras figuras como artistacientífico, artista-investigador o artista-divulgador; y c) el estatuto de espectador varía de un contemplador pasivo a un testigo, invitado, protagonista o coproductor. 
Una última hipótesis refiere a la reducción epistemológica moderna del concepto de experiencia que separa la experiencia científica de la experiencia artística. En este sentido se considera que el bioarte concilia las dos concepciones de experiencia escindidas por la modernidad. En consecuencia, se sostiene que el bioarte como práctica artística novedosa abre un campo de reflexión y discusión en el campo de la estética.

Por lo tanto en cuanto al tema de estudio, el propósito de esta tesis es el de determinar las especificidades estéticas del bioarte a partir de la estrecha relación que mantiene con el lenguaje y las prácticas científicas. En ese marco, se propone establecer su puesta en crisis con ciertas categorías estéticas que derivan de la modernidad tales como la de creación, obra, artista, espectador y experiencia, que da lugar a las nuevas reconfiguraciones que propicia el arte contemporáneo.

Como objetivos específicos se intentará describir los modos en que el bioarte hace uso del discurso científico, caracterizar el quiebre con las obras de arte tradicional que se presentan de forma continua y permanente, identificar los criterios clasificatorios vinculados a los nuevos comportamientos espectatoriales, tipologizar las figuras de artista emergentes del bioarte y reflexionar acerca del concepto de experiencia en la modernidad.

Respecto del marco conceptual que está en la base de nuestra tesis, el bioarte es un concepto amplio que ha variado en el tiempo y que por tanto puede involucrar a una gran cantidad de obras, o por el contrario, referir a una porción acotada. Sobre la base del marco teórico estudiado, se entiende que el bioarte incluye a obras que utilizan los recursos de la biotecnología para manipular organismos vivos a niveles discretos. El resultado es la realización de producciones artísticas que presentan organismos elaborados mediante transferencia genética, clonación o ingeniería tisular, entre otros. 
Esta producción biotecnológica es llevada a cabo en laboratorios fijos establecidos en universidades, compañías privadas e instituciones públicas, o en laboratorios móviles a través de kits portátiles y cuartos asépticos transportables. Además, las obras suelen acompañarse de artefactos robóticos o tecnológicos para asegurar el mantenimiento de los organismos vivos.

En consecuencia, lo que excluye esta tesis son aquellas obras que trabajan con entornos virtuales o artificiales que simulan los procesos biológicos como la vida artificial, el arte genético (basado en algoritmos genéticos), el arte evolutivo (basado en algoritmos evolutivos) o el arte robótico. Tampoco comprende obras que trabajen con organismos vivos no modificados genéticamente, ni manipulados en condiciones in vitro, como el arte ecológico y el land art. La utilización de plantas naturales sin ningún tipo de manipulación unidas a dispositivos electrónicos o robóticos como por ejemplo Breathing y Equilibrium del brasilero Guto Nóbrega o Pulsu(m) Plantae de la mexicana Leslie García no serán consideradas parte del corpus, aunque sí es importante destacar los desarrollos tecnológicos que producen en open source posibles de ser utilizados en obras de bioarte.

El resultado es una clara tendencia hacia la caracterización del bioarte como un arte viviente que ha pasado por el ámbito de laboratorio para su manipulación, ya sea a nivel genético (modificación o alteración de material genético nuclear o mitocondrial) o a nivel celular (cultivo, reproducción y propagación celular o tisular in vitro). Esta definición específica que algunos autores denominan "hard" ${ }^{5}$ permite delimitar el corpus de obras y artistas a número razonable para su análisis en profundidad.

\footnotetext{
5Joaquín Fargas considera que hay dos clases de bioarte, uno "soft" que es más abarcativo y que incluye toda aquella obra que tenga algo vivo en su estructura, y otro "hard" que remite exclusivamente al trabajo con biotecnología. Por su parte, Jens Hauser señala que el bioarte pasó de ser un arte basado en la inmaterialidad del software (como por ejemplo la simulación de los cruzamientos hereditarios) a otro centrado en la materialidad del hardware, una materialidad física, tangible, formada por átomos y genes donde los cruzamientos hereditarios ya no son simulados en una computadora sino realizados sobre material genético en el laboratorio.
} 
Cronológicamente, esta investigación circunscribe el período comprendido entre 1980 y 2012. La fecha de inicio está dada por la periodización que realizan Daniel López del Rincón y Lourdes Cirlot $^{6}$, quienes señalan que a partir de 1980 surge la primera generación de bioartistas con autores como George Gessert y Joe Davis.

Por ser un arte actual, la producción de obras es constante y permanente por ello se decidió dar como fecha de cierre el año 2012 para poder trabajar con cierta perspectiva temporal en el análisis de los casos.

Dado que el conjunto de problemas que abarca esta investigación refiere a una problemática más general propia de las reconfiguraciones del arte contemporáneo, no se han establecido límites geográficos para la selección de los casos. Por otro lado, a causa del carácter global de este género artístico y los intercambios que se producen entre artistas, laboratorios y universidades de todo el mundo, se ha decidido no acotar la unidad de análisis al campo estrictamente latinoamericano que es la línea de investigación propuesta por el Doctorado en Artes de la Facultad de Bellas Artes de la Universidad Nacional de La Plata.

Así como las problemáticas estéticas analizadas son cuestionamientos a nivel global, las obras de bioarte también trabajan -con excepciones- problemas generales que disuelven la identidad local y específica de una cultura. Salvo algunos casos que se

\footnotetext{
${ }^{6}$ López del Rincón y Cirlot contemplan cuatro fases en la historia de la confluencia entre arte, biología y tecnología: $1^{\circ}$ fase (1920-1985): Los precursores. $2^{\circ}$ fase (1980-1992): La primera generación de bioartistas. $3^{\circ}$ fase (1993-2001): De la hegemonía del arte genético a la heterogeneidad del arte biotecnológico. $4^{\circ}$ fase (2002-actualidad): La consolidación del bioarte como movimiento artístico. López del Rincón, D. y Cirlot, L. (2013, noviembre). "Historiando el bioarte o los retos metodológicos de la Historia del Arte (de los medios)". Artnodes, (13), 62-71.

Otra periodización relevante, es la que realiza Robert Mitchell en su texto BioArt and the Vitality of Media, quien identifica tres etapas en el desarrollo del bioarte. La primera (1930-1940) está basada en el uso de las leyes de la herencia de Mendel. La segunda (1970-1990) se corresponde con la superación del "silencio" en genética como consecuencia de la política nazi sobre la idea de raza; en este período se incorporan nuevas técnicas de biología molecular a la intervención genética y surgen las primeras obras a través de artistas como George Gessert, Joe Davis y Eduardo Kac. La tercera etapa (desde 2004) está basada en la relación entre bioarte y bioterrorismo tomando como inicio el procesamiento legal que recibió Steve Kurtz del Crititcal Art Ensemeble. Mitchell, R. (2010). Bioart and the vitality of the media. Seattle: University of Washington Press.

Por lo tanto, estos tres autores señalan que los primeros artistas interesados en el trabajo con genética y ADN fueron George Gessert y Joe Davis, cuyas producciones bioartísticas se iniciaron en la década del ochenta, coincidiendo con los albores del desarrollo de las ciencias biotecnológicas.
} 
vinculan con la crítica a ciertos aspectos políticos o sociales nacionales, como las obras de Steve Kurtz contra la política tecnocientífica norteamericana o los trabajos de Daniel Álvarez Olmedo que exponen la realidad social argentina mediante el uso de estadísticas oficiales; el interés de esta tesis no es estudiar cuestiones de identidad del arte regional sino problemas que atañen al arte contemporáneo en general.

Por lo antedicho, debido al carácter global del bioarte, se han tomado referentes de todo el mundo que pueden ser agrupados en cuatro polos principales de producción artística. El primero es América del Sur a través de los artistas participantes del Laboratorio Argentino de Bioarte, también se incluye a la rosarina Luciana Paoletti, al brasilero Eduardo Kac (que reside en Estados Unidos) y al chileno Allan Jeffs (que reside en Ecuador). El segundo polo es América del Norte a través de artistas que trabajan tanto independientemente como bajo la tutela de universidades de México, Estados Unidos y Canadá, algunos casos son Gilberto Esparza (independiente, trabaja en colaboración con diversas universidades de México), Tagny Duff (Concordia University, Canadá), Steve Kurtz (University at Buffalo, Estados Unidos), Paul Vanouse (University at Buffalo, Estados Unidos) y Adam Zaretsky (independiente, trabaja en Estados Unidos). El tercer polo es Europa mediante artistas que se desplazan por distintos laboratorios de bioarte y centros de ciencia de Portugal, España, Finlandia, Gran Bretaña u Holanda tales como Marta de Menezes y Andy Gracie, entre otros. Finalmente, el cuarto polo es Oceanía a través del laboratorio SymbioticA ubicado en Australia cuyos principales referentes son Oron Catts, Ionat Zurr y Guy Ben-Ary.

Las obras y artistas seleccionados surgen de estos cuatro polos de producción y se destacan por haber sido presentados en galerías, museos, festivales y sitios reconocidos por la comunidad artística. 
En cuanto a la metodología empleada se determinó que las unidades de análisis son de dos tipos: obras de bioarte y bioartistas. En la mayoría de los casos el acceso a las mismas es a través de los textos de referencia como:

- Textos de artistas: manifiestos, artículos de divulgación, textos explicativos o de referencia, biografías.

- Textos críticos: artículos en los medios como críticas, reseñas, entrevistas.

- Textos académicos: tesis de investigación, artículos de divulgación, ensayos, ponencias.

- Textos de estudios artísticos: textos de historia del arte, teoría del arte, estética, catálogos.

Por lo tanto, dado el carácter estético de este estudio, procederemos de manera hipotética, complementando la descripción, el análisis, la interpretación de los hechos artísticos que nos ocupan con la demostración argumentativa de nuestras hipótesis. Nuestra perspectiva, a la vez crítica y metacrítica, no pretende llegar a verdades concluyentes sino a respuestas provisorias que permitan formular nuevos interrogantes así como realizar un aporte a la reflexión y comprensión estética del bioarte.

Sobre la estructura de la tesis:

Esta tesis se inicia con Algunas palabras para comenzar, el relato de una anécdota que tiene por objeto presentar el tema a través de una historia que pone en evidencia la complejidad del bioarte, haciendo necesario e inminente su estudio con el fin de intentar comprender algunos de estos problemas que atañen al arte contemporáneo. Luego de la Introducción, el cuerpo de la tesis, consta de dos partes diferenciadas: una primera, a modo de preámbulo de la segunda que abordará de lleno el objeto de 
estudio. La primera parte incluye el Marco teórico donde se define la terminología y los límites conceptuales del término bioarte. Además, se indagan las relaciones entre arte, ciencia y filosofía; cómo abordan el tema de la vida cada una de estas categorías, la vida como lenguaje, la obra como metáfora de la vida. El bioarte pone en primer plano la pregunta sobre qué es la vida más que plantear una respuesta, en este sentido, refuerza la pregunta por lo viviente permitiendo reflexionar sobre ello de manera crítica. Por último, se describe el estado de la cuestión al plantear la discusión estética sobre el bioarte, dando cuenta de una serie de nudos problemáticos que se trabajarán posteriormente.

Una vez introducido en el tema de estudio, la segunda parte del cuerpo de la tesis se inicia con el capítulo Sobre el concepto de obra, donde se pretende caracterizar algunas de las transformaciones que el arte contemporáneo opera sobre las concepciones más tradicionales de obra, derivadas fundamentalmente de estéticas modernas. Así, se verá como la introducción en la contemporaneidad de nuevos materiales y dispositivos como la performance o la instalación posibilitan el pasaje de una obra continua, permanente, con un tiempo y espacio determinado hacia una obra efímera, móvil, híbrida, con tiempos y espacios variables. Se estudiará un caso particular de bioarte que se llevó a cabo en el Museo de Arte Moderno de Nueva York. En el siguiente capítulo, Figuras de artista, pretende mostrar el modo como el bioarte pone en crisis e introduce transformaciones en las nociones de creación y de artista. En este sentido, se retomará la idea contemporánea de la "muerte de autor" -que cuestiona la figura de artista derivada del renacimiento y sobre todo del romanticismovinculada a la emergencia de nuevas figuras de artista propiciadas por el arte contemporáneo y el bioarte. A través del análisis de los textos de artista constituidos principalmente por reportajes mediáticos, entrevistas personales, datos biográficos y 
escritos de autor, se establecerán lo que podríamos denominar tres figuras de artista en relación al rol que desempeña: a) el artista-científico; b) el artista-investigador; c) el artista-divulgador. Esta distinción se realiza atendiendo más bien a lo que se podría llamar la fase productiva del bioarte, a partir de los siguientes indicadores: a) si la obra es desarrollada por el propio artista en el laboratorio siguiendo los protocolos y metodologías de las ciencias biotecnológicas; b) si el artista conoce el resultado al que quiere llegar pero terceriza o transfiere el trabajo técnico de laboratorio a científicos especializados; c) si el artista intenta con su obra acercar el conocimiento científico a un público no especializado.

El capítulo que continúa, El rol del espectador, se enfoca en el aspecto receptivo para determinar las modificaciones introducidas en el papel del receptor. Al describir los distintos roles que asume el espectador según el lugar que le asigna cada obra de bioarte, vemos el modo como el bioarte profundiza la tendencia del arte contemporáneo a enfatizar el papel del receptor. En efecto, a partir del corpus de obras estudiadas se establecerán seis roles de espectador a) espectador-observador; b) espectador-invitado; c) espectador-testigo; d) espectador-intruso; e) espectadorprotagonista y f) espectador-coproductor. Estas distinciones están elaboradas sobre la base de los siguientes indicadores: a) si la obra plantea una mínima participación del espectador; b) si las obras son performativas y convierten al espectador en quien da fe de la acción que ocurre en vivo; c) si las obras son interactivas y requieren de un espectador para ayudar en su funcionamiento; d) si el espectador interfiere en el desarrollo regular de la obra, irrumpiendo de algún modo la evolución normal del ciclo de vida del objeto artístico; e) si la obra requiere de la participación activa de un solo receptor; f) si el espectador trabaja conjuntamente con el artista en la producción y desarrollo de la obra. 
El último capítulo, Bioarte como síntesis de la experiencia, es una reflexión acerca de las diversas nociones de experiencia: una derivada de las concepciones modernas del conocimiento y la ciencia que la entiende como recepción de información sensorial y la vincula a la experimentación científica con sus pretensiones de verificación y objetividad; otra, derivada del arte y la reflexión estética, la vincula a la disposición humana para experimentar el placer estético. Así, sostendremos que el bioarte en tanto género artístico contemporáneo que se nutre de las investigaciones y desarrollos en biotecnología, pretende conciliar esas dos concepciones de experiencia.

A continuación, en las Conclusiones se plasman algunas de las ideas principales abordadas en la tesis para dar un panorama general del tema analizado y exponer las conclusiones que, como se dijo, continúan siendo hipotéticas y provisorias.

En cuanto a la Bibliografía, se halla citado el material que constituye el marco teórico de referencia para este análisis, se ha separado en bibliografía general y bibliografía específica que refiere al bioarte. Finamente, el apartado Apéndicese divide en dos tipos, uno gráfico incluido al final de este escrito y otro electrónico en soporte CD. En el primero se adjuntan las imágenes de las obras y en el segundo los videos y material extra de las producciones que se desarrollan en el tiempo. Ambas instancias constituyen una referencia necesaria para salvar la novedad de las obras, así como también para ilustrar su análisis. 
2. MARCO TEÓRICO 


\subsection{Acerca del concepto de bioarte ${ }^{7}$}

El término bioarte fue propuesto por Eduardo Kac por primera vez en 1997 para describir las características de un grupo de obras basadas en técnicas de manipulación genética:

El arte está siempre cambiando. En el 97 propuse el término de bioarte. Es un principio amplio de manipulación de la vida, que implica trabajar con el proceso vital, con lo que ocurre cuando la vida se desarrolla. ${ }^{8}$

Más tarde, el término fue utilizado para designar a otros grupos de obras, no solamente las que producía Eduardo Kac, estableciendo así las bases de un nuevo género que se inscribía en el marco de los desarrollos interdisciplinarios que combinan arte, ciencia y tecnología. La novedad que imprimió el bioarte a diferencia de otras prácticas interdisciplinarias de este tipo (como las tradicionales arte óptico, arte cinético, arte de los medios, y otras más recientes, como el arte genético o el arte evolutivo) es que el ámbito de investigación, experimentación y producción de las obras se da en laboratorios de biotecnología lo que implica la utilización de técnicas, metodologías y protocolos específicos de las ciencias biológicas.

Algunas de las discusiones más interesantes sobre la conceptualización del bioarte se generaron en el ámbito de la web. Los foros y listas de discusión fueron el lugar propicio para que personalidades destacadas de todo el mundo discutieran al mismo

\footnotetext{
7 Algunas ideas vertidas en este capítulo han sido desarrolladas para la tesis de Magíster “Aproximaciones al Bioarte: concepto - cuerpo - género", FBA-UNLP, La Plata, 2009.

${ }^{8}$ Entrevista a Eduardo Kac de Espinosa Vera, C. H. (julio de 2006). "Eduardo Kac: en realidad, todos somos transgénicos". Escáner cultural, año 8, (85).
} 
tiempo sobre el tema. En el año 2006, Julien Knebusch, moderadora de la lista de discusión YASMIN ${ }^{9}$ invitó a nueve personalidades ${ }^{10}$ ligadas a la curaduría, la filosofía, la crítica y la práctica artística a debatir durante 10 días sobre los aspectos exhibitivos del bioarte. El 27 de febrero de 2006, Mónica Bello escribió el primer mensaje donde señalaba diferentes cuestiones acerca de la exhibición de obras de bioarte

En el desarrollo de mi propia exhibición "Organismos: esto es vida" Ilevada a cabo en La Casa Encendida en Madrid, en el insoportablemente caluroso verano de 2004, tuve la oportunidad de identificar algunas cuestiones relativas a la exhibición de arte con sistemas vivos (...) ¿La duración de una exhibición de bioarte está limitada al tiempo de vida de la obra? (...) ¿Es igual de efectivo exhibir la obra de bioarte como residuo, como presentación o como documentación? (...) ¿Las obras deberían ser museables, comprensibles, claras y transparentes para que el público, los medios y las instituciones las acepten $?^{11}$

Las respuestas a este mensaje y a sus preguntas no tardaron en llegar pero estuvieron dirigidas principalmente a cuestionar, no tanto las problemáticas exhibitivas, sino aquello que Bello consideraba bioarte, es decir, una práctica artística ligada exclusivamente al trabajo con medio orgánico vivo (células, tejido orgánico, plantas, peces, insectos, mamíferos, etc.). Roger Malina ${ }^{12}$ fue el primero en hacerle ese tipo de observación al señalarle dos problemas, el primero tenía que ver con el cuestionamiento sobre el arte como residuo o documentación, un problema que no era nuevo pues también afectaba al arte conceptual y al arte performativo. El segundo, es que existían otras clases de bioarte aparte del que incluía obras con organismos vivos,

\footnotetext{
${ }^{9}$ YASMIN (Your Arts Science Mediterranean International Network) es una lista de discusión moderada creada para debatir cuestiones relacionadas con las intersecciones entre arte, ciencia y tecnología en la región del Mediterráneo.

${ }_{10}$ Las nueve personalidades invitadas fueron: Annick Bureaud (París, Francia), Pier Luigi Capucci (Bolonia, Italia), Nina Czegledy (Montreal, Francia), Pau David Alsina Gonzalez (Barcelona, España), Jens Hauser (París, Francia), Anna Hatziyiannaki (Atenas, Grecia), Beral Marda (Estambul, Turquía), Tomislav Medak (Zagreb, Croacia) y Polona Tratnik (Liubliana, Eslovenia). Sin embargo, la lista estaba abierta a la participación de otros miembros.

${ }_{11}$ Mónica Bello Bugallo, mensaje publicado el 27/02/2006 en YASMIN, http://www.media.uoa.gr/yasmin/viewtopic.php?t=775, en línea 5 de enero de 2009. La traducción es mía. ${ }_{12}$ Roger Malina, mensaje publicado el 01/03/2006 en YASMIN, http://www.media.uoa.gr/yasmin/viewtopic.php?t=775, en línea 5 de enero de 2009.
} 
como por ejemplo la línea que trabajaba con Vida Artificial: "La Vida-A es definida como la biología de la vida 'que podría ser', por lo tanto desde mi punto de vista las obras de bioarte necesitan incluir el arte de vida-a." ${ }^{13}$

Esta idea de Malina fue avalada por los mensajes de Ana Leonor Madeira Rodrigues y Pier Luigi Capucci ${ }^{14}$, entre otros, quienes también entendían que el campo de acción del bioarte era más amplio e incluía el uso de técnicas digitales que permitían simular los mecanismos, procesos y transformaciones de la vida a través de la Inteligencia Artificial o la Vida-A.

En este punto, Mónica Bello envió un mensaje explicitando su marco teórico basado principalmente en el pensamiento de Jens Hauser y Eduardo Kac, el cual le permitía entender al bioarte como un "arte de transformación en vivo que manipula materiales a niveles discretos (por ejemplo células individuales, proteínas, genes, nucleotidos) y crea dispositivos que permiten a la audiencia participar de ello tanto emocional como cognitivamente". ${ }^{15}$ En este sentido, Bello considera que los artistas que abordan el bioarte están más interesados en el trabajo con los procesos y las transformaciones físicas, reales, de los organismos vivos que en la simulación virtual de los mismos. Y que su idea era dirigir la discusión hacia ese enfoque.

El conflicto protagonizado principalmente entre Bello y Malina, pone de manifiesto el problema que refiere a la sistematización de las distintas conceptualizaciones sobre bioarte. La dificultad de acotar terminológicamente este concepto y definir sus propiedades constitutivas se debe a que, en palabras de Jens Hauser, el bioarte está

\footnotetext{
13 Roger Malina, mensaje publicado el 01/03/2006 en YASMIN, http://www.media.uoa.gr/yasmin/viewtopic.php?t=775, en línea 5 de enero de 2009. 14 Ana Leonor M. Madeira Rodrigues y Pier Luigi Capucci, mensajes publicados el 02/03/2006 en YASMIN, http://www.media.uoa.gr/yasmin/viewtopic.php?t=775, en línea 5 de enero de 2009.

15 Citado por Mónica Bello Bugallo, mensajes publicados el 04/03/2006 en YASMIN, http://www.media.uoa.gr/yasmin/viewtopic.php?t=775, en línea 5 de enero de 2009.
} 
en constante cambio ${ }^{16}$ ya que en los últimos años su estatus se redefinió y pasó de una concepción inmaterial dada por la simulación digital de los procesos biológicos a una concepción material que se funda en el trabajo con componentes orgánicos vivos. Según explica Hauser, en un principio el bioarte se vinculaba con las producciones digitales de arte genético ${ }^{17}$ y vida artificial que contemplaban la realización de una clase de arte basado en los estudios de las ciencias biológicas. Posteriormente fue adquiriendo cada vez más el estatus de un arte viviente como consecuencia de la incorporación de la práctica y los productos de la biología húmeda. ${ }^{18}$ Por otra parte, si bien en el origen se lo relacionó con las artes digitales, la mayoría de los artistas involucrados provenían del campo del body art y la performance, por cuanto los modos de producción y exhibición del bioarte se vinculaban más con el arte performativo y conceptual que con las artes electrónicas. Todos estos cambios en las propiedades que definen y constituyen al bioarte son explicados por Hauser a través de cuatro operaciones: simulación, rematerialización, performance y conceptualización.

Las operaciones descriptas por Hauser manifiestan el pasaje del bioarte, primero como un arte inmaterial, y luego, como un arte material y vivo. En este sentido Kac menciona tres rasgos característicos del bioarte que permiten diferenciarlo, además, de otras prácticas que incluyen la presencia de organismos vivos como el land art, el arte ecológico o el body art: 1) la transformación de biomateriales en formas o comportamientos específicos; 2) la utilización subversiva o inusual de los procesos y

\footnotetext{
${ }^{16}$ Hauser, J. (2005). "Bio Art - Taxonomy of an etymological monster". En C. Schöpf y G. Stocker (Eds.), Hybrid, living in paradox. Austria: Hatje Cantz, p. 182.

${ }_{17}$ El arte genético fue desarrollado por Karl Sims en los años noventa a partir de la utilización de algoritmos genéticos para la creación de obras artísticas. Matewecki, N. (2007). "Arte genético / Arte transgénico. ¿Arte o Ciencia?”. B, año 1, (1), 117-121.

${ }^{18}$ Del inglés wet biology, también conocida como biología experimental, refiere a las investigaciones y desarrollos en ciencia biológicas que se basan en el uso de unidades discretas como células, genes, proteínas, etc.
} 
las herramientas de la biotecnología y 3) la invención o transformación de organismos vivos con o sin integración ambiental o social (desde una célula hasta un mamífero). ${ }^{19}$ Para Hauser ${ }^{20}$ existe indudablemente una problemática etimológica pero que, si bien algunos de los términos utilizados son más específicos y otros más generales, cada uno de los protagonistas que trabajan en este campo coinciden aproximadamente en los términos utilizados: Vivo Arts, Moist Media Art, Life Science Art, Biotech Art, Live Art, Wet Art, Transgenic Art, Genetic Art, Bio Art. Todos y cada uno de estos términos describen una práctica artística que involucra métodos de manipulación de los sistemas vivos que permiten describir los procesos de transformación in vivo o in vitro. Por otra parte, Hauser advierte que intentar definir al bioarte aludiendo únicamente a una cuestión temática -la representación de los sistemas biológicos- es caer en un grave riesgo teórico

(...) nadie actualmente podría pensar en categorizar las pinturas conceptuales de Miltos Maneta que representan joysticks, mouse de computadoras y marañas de cables como arte cibernético o media $\operatorname{art}(\ldots)^{21}$

El bioarte es un concepto que ha variado a través del tiempo pero que conserva cierta especificidad que va más allá de una cuestión temática ligada a la naturaleza o a la biología. Una obra no puede ser inscripta dentro de este género basándose simplemente en el contenido que representa porque entonces, ejemplifica Hauser, las pinturas impresionistas de Claude Monet que representan a la naturaleza también serían bioarte.

A partir de las problemáticas manifiestas en torno a la acotación terminológica, se puede afirmar que el bioarte es un género artístico que se vincula con los procesos

\footnotetext{
${ }^{19}$ Kac, E. (2007). "Introduction" en Signs of life. Bioart and beyond. London: MIT Press, p. 18.

20 Jens Hauser, mensaje enviado el 07/03/2008 a Synapse elist.

${ }^{21}$ La traducción es mía. "(...) nobody today would even think of categorizing Miltos Maneta's conceptual oil paintings depicting joysticks, computer mice and tangled thickets of cables and wires as computer art o media art (...). Hauser, J. Op. cit., p.182.
} 
vitales. Al principio, el término estuvo vinculado con las producciones artísticas que utilizaban Inteligencia Artificial y Vida-A para simular el desarrollo de los procesos biológicos como el nacimiento, el crecimiento, la reproducción y la muerte. Más tarde, la incorporación de la biología húmeda a la práctica artística posibilitó el estudio de esos procesos vitales a nivel molecular.

De este modo, las obras que incluyen ingeniería tisular, trabajo con virus u organismos transgénicos, se enfrentan con dos cuestiones, la primera, el carácter efímero de su producción cuyo tiempo de vida es acotado; y la segunda, la focalización en el aspecto conceptual que surge como consecuencia del trabajo con manipulación genética o celular (cuestionamientos éticos, estéticos, políticos). Por este motivo, el bioarte se acerca más a los modos de producción, exhibición y registro del arte conceptual o del arte performativo, que a las prácticas artísticas electrónicas y digitales.

\subsection{Ciencia, arte, filosofía. Hibridaciones, cruces, convergencias}

A partir de la modernidad, y en diversas concepciones epistemológicas, se propusieron criterios de distinción entre las ciencias (entre ellas las ciencias biológicas) la filosofía y el arte. ${ }^{22} E n$ este sentido, en los tres campos suele plantearse la pregunta por la vida que es abordada de distintos modos, a veces desde la divergencia y en otros desde la convergencia de lenguajes, métodos y saberes. La combinación de aspectos científicos, filosóficos y artísticos que presenta el bioarte lo ubica como un ejemplo de cruces, hibridaciones y mixturas cuya producción y reflexión comprende la cuestión de lo viviente. Así, el bioarte explora tanto lo vivo como lo no vivo y se anima a introducir una nueva y conflictiva categoría, la de lo semi-vivo.

${ }^{22}$ Cf. Ayer, A. (Ed.). (1965). El positivismo lógico. Madrid: FCE. Popper, K. (1979). "Tres concepciones sobre el conocimiento científico". El desarrollo del conocimiento científico. Conjeturas y refutaciones. Buenos Aires: Paidós. Bunge, M. (eds. vs.). La investigación científica. Barcelona: Ariel. 
El estudio de lo vivo, de la vida y de los seres vivientes es el campo de acción específico de la biología. Esta disciplina se apoya en otras ciencias, principalmente la física y la química, pero también en las matemáticas para comprender el origen, funcionamiento y desarrollo del estrato biológico, es decir, de todo aquello vinculado a lo viviente.

Los compuestos químicos complejos presentan funciones específicas que dan fundamento a una serie de procesos vitales como el crecimiento, la organización, el metabolismo, la absorción, la asimilación, la secreción, la excreción, el movimiento, la reproducción, la irritabilidad, la conductibilidad y la adaptación. ${ }^{23}$ Este compuesto de moléculas que conforma a los seres vivos presenta algo que le es propio y que lo diferencia de la materia inerte: la vida; Mario Vestfrid señala que "querer explicar que es la vida es tan o más difícil que tratar de caracterizar a la materia viva" ${ }^{24}$.

El mecanicismo se basa en las leyes de la física y la química para interpretar y explicar los procesos vitales. Existe una diferencia gradual entre el mundo inorgánico de la materia inerte y el mundo orgánico de los seres vivos, por ello los mecanicistas analizan los procesos vitales del mismo modo que investigan la materia inanimada, utilizando los métodos propios de la física y de la química.

En el siglo XVIII surge dentro de la biología un enfoque diferente al mecanicismo conocido como vitalismo que considera insuficientes a las leyes de la física y de la química para explicar la totalidad de los procesos vitales. Retomando algunos aspectos de Platón y Plotino, el vitalismo considera que existe una diferencia en el mundo de lo inorgánico y el de los seres vivos que estaría dado por una fuerza extraña, misteriosa y divina inherente exclusivamente al organismo vivo: "según el vitalismo en todo organismo vivo, sobre el factor material actuaría otro factor de índole

\footnotetext{
${ }^{23}$ Vestfried, M. (1988). Filosofía Biológica. Buenos Aires: Celcius, pp 89-90.

${ }^{24}$ Ibid., p.89.
} 
supranatural" 25 , una "fuerza vital" que se encarga de dirigir los procesos que se efectúan en los organismos vivientes.

Tanto el mecanicismo como el vitalismo pugnaban por imponer sus ideas y teorías sobre el origen de la vida en el campo de la biología, sin embargo a mediados del siglo XIX una nueva corriente llamada evolucionismo se fue afianzando e imponiendo sus teorías dentro de la biología para resolver el problema del origen de la vida.

En Destinos personales Remo Bodei propone un recorrido para hablar sobre el individuo y la construcción del sujeto que va de la citología a la filosofía. Esta relación entre biología y filosofía existe debido a una serie de cuestionamientos que son comunes a ambas disciplinas: cuándo y cómo se originó la vida, qué es un ser vivo, a qué denominar sujeto, qué es un individuo. Este autor parte de los análisis microscópicos de Schleiden y Schwann ${ }^{26}$ que señalan a la célula como la unidad fundamental de todo organismo vegetal y animal, confirmando así la existencia de una estructura elemental común a todos los seres vivientes. Estos desarrollos permitieron dar una explicación de los fenómenos de la vida, primero, y después poder interpretar los procesos psíquicos, sociales y filosóficos. ${ }^{27}$

La célula entendida como unidad mínima de un organismo guarda, para muchos autores, las respuestas a los interrogantes sobre el origen de la vida y los seres vivos. Ante las preguntas ¿Qué sucedió cuando se originó la vida? ¿Qué comenzó al comenzar la vida de modo que se pueda decir que la vida comienza en ese momento ${ }^{28}$ Maturana y Varela desarrollan una teoría tanto científica como filosófica

\footnotetext{
${ }^{25}$ Ibid., p.91.

${ }^{26}$ Schwann, T. (1839) "hay un principio general de construcción para todas las producciones orgánicas y este principio de construcción es la formación de la célula."

${ }_{27}$ Bodei, R. (2006). Destinos personales. La era de la colonización de las conciencias. Buenos Aires: EI cuenco de plata, pp.81-82.

${ }^{28}$ Maturana, H. y Varela, F. (1972/2003). De máquinas y seres vivos: autopoiesis, la organización de lo vivo. Buenos Aires: Lumen, p.10.
} 
acerca de lo viviente para explicar y describir cómo se constituye y opera el ser vivo en el nivel más discreto de la biología, el nivel molecular.

El ser vivo es y existe como ente molecular autónomo sólo en tanto permanece en la conservación de su organización. Esta organización que denominan autopoiesis, consiste en un proceso de relaciones e interacciones cerrado en sí mismo, cerrado en la propia dinámica del ente molecular (de una célula o de una neurona). Existen distintos sistemas autopoiéticos como la cultura, la familia o la sociedad que son entendidos como espacios de relaciones, de comunicaciones, de conversaciones pero que no son de modo alguno seres vivos.

La teoría de lo viviente explicita que el ser vivo no depende de una dinámica de organización circular para vivir, sino que el ser vivo es esa dinámica, es un sistema de organización relacional y cerrado. El ser vivo es un ser viviente por este modo particular de organización que exponen los autores:

a) que el ser vivo es, como ente, una dinámica molecular, no un conjunto de moléculas; b) que el vivir es la realización, sin interrupción, de esa dinámica en una configuración de relaciones que conserva en una continuo flujo molecular; y c) que en tanto el vivir es y existe como una dinámica molecular, no es que el ser vivo use esa dinámica para ser, producirse o regenerarse a sí mismo, sino que es esa dinámica lo que de hecho lo constituye como ente vivo en la autonomía de su vivir. ${ }^{29}$

La explicación de lo viviente se debe dar, primero, en el nivel molecular -pues sólo en ese nivel opera el ser vivo autónomamente- y segundo, en su modo de organización circular y cerrado -ya que ser vivo y sistema autopoiético son lo mismo. ${ }^{30}$

Lo que describen Maturana y Varela, en definitiva, es la caracterización de la célula como ente molecular autónomo. Es interesante y necesario por tanto reflexionar acerca de la relación que pudiera existir entre la autonomía de la célula y las nociones

\footnotetext{
${ }^{29}$ Ibid., pp. 15-16.

${ }^{30}$ Ibid., p. 18.
} 
de individuo, sujeto y ser. El uso del término "célula" fue acuñado en 1667 por Robert Hooke por el parecido que hallaba con la estructura de celdas que conforma las colmenas. Este ejemplo plantea una serie de complejidades asociadas a la idea de individualidad y comunidad ya que una colmena puede entenderse como un organismo compuesto de abejas individuales que se comportan autónomamente de modo similar al comportamiento de un ente celular. Esta visión de la abeja como individuo independiente de la estructura de la colmena es comparable con el estudio de las células en condiciones de laboratorio que son sacadas de su contexto de origen, apartadas de su cuerpo y aisladas en una cápsula de Petri. ${ }^{31}$ Esta fragmentación del cuerpo en células individuales que pueden mantenerse vivas y comportarse de manera autónoma fuera de su cuerpo original y de su complejo sistema inmune conduce a Huxley, Wells y Wells a señalar que
Podríamos comparar el cuerpo con una comunidad, y las células con los individuos de los cuales se compone esta vasta población organizada. Es muy importante darse cuenta de que esta comparación no es meramente alegórica. Es una afirmación de un hecho, ya que -recurrimos aquí al énfasis en la cursiva- las células individuales se pueden aislar del resto del cuerpo y permanecer vivas. ${ }^{32}$

Por lo tanto, si el cuerpo es una comunidad de células ¿Cómo nos podemos referir a la colección de células que crecen fuera de ese cuerpo? ¿Cuál sería la "comunidad" a la que pertenecen $?^{33}$. Cuando las células y los tejidos son extraídos del cuerpo de origen para mantenerlos vivos bajo condiciones experimentales de laboratorio (más precisamente en entornos tecnológicos donde se controla el oxígeno, el pH, la temperatura, la humedad y se los alimenta artificialmente) también se los despoja de otros muchos aspectos concernientes a un individuo vivo como el tamaño, la textura,

\footnotetext{
${ }^{31}$ Catts, O. y Zurr, I. (noviembre de 2006). "Hacia una nueva clase de ser. El cuerpo extendido". Artnodes, (6), 3-12.

${ }_{32}^{32}$ Huxley, Wells y Wells en Catts, O. y Zurr, I. Ibid., p. 6.

${ }^{33}$ Ibid., p. 6.
} 
el vínculo con otras especies, la relación con el tiempo y espacio. Resulta evidente, indican Oron Catts y lonat Zurr, que cualquier tipo de célula y tejido disociado ya sea humano, animal o vegetal, comparten un común denominador: están vivos y necesitan ayuda tecnológica para poder coexistir. El conjunto de estos entes moleculares alejados de su cuerpo huésped y conviviendo en un nuevo espacio-tiempo dan lugar a la conformación de una nueva clase de comunidad que

(...) no se ajusta a las clasificaciones biológicas y culturales comunes y presenta un reto tanto ontológico como epistemológico: ontológico porque pone en duda la definición de ser de un modo muy básico y fundamental; y epistemológico porque cuestiona nuestra producción de conocimiento desde la perspectiva de una colección fuera de contexto y fragmentada de seres "más-o-menos-vivos" ${ }^{4}$

Este conjunto de células y tejidos disgregados viviendo en un entorno tecnológico que actúa de cuerpo sustituto forma parte de una noción general que desarrollaron Catts y Zurr y que se denomina "cuerpo extendido":

El cuerpo extendido es un constructo que puede permitirnos cuestionar la clasificación del mundo según humanos / animales / entidades no vivas y mirar a los semivivos que se encuentran entre humano y animal (células de humanos y animales fusionadas juntas), objeto y humano (un constructo de tejido modificado formado por células humanas), objeto y animal (un constructo de tejido modificado formado por células animales), etc. ${ }^{35}$

El cuerpo extendido abarca todas las células y tejidos que se extraen de sus cuerpos huésped, son células, tejidos y órganos sin un cuerpo natural que conviven, se desarrollan, multiplican e inclusive fusionan dentro de un cuerpo tecnocientífico (por ejemplo un biorreactor). La flexibilidad que manifiesta el cuerpo extendido, es decir, la capacidad que presenta esta comunidad de fragmentos extraídos de hibridarse sin tener en cuenta la especie, raza, sexo o edad del cuerpo de origen, da lugar al

\footnotetext{
${ }^{34}$ Ibid., p. 6.

${ }^{35}$ Ibid., p. 8.
} 
nacimiento de nuevas clases de seres -o como denominan Catts y Zurr- "semi-seres". ¿Pero por qué les llaman semi-seres y no simplemente seres vivos? Para estos autores son semi-seres por varias razones: primero, porque los fragmentos de células y tejidos son extraídos de un cuerpo con un sistema inmune determinado e introducidos dentro de un nuevo cuerpo que no rechaza ningún agente externo que quiera pasar a formar parte de él, de modo que este nuevo cuerpo vulnerable aún no es definido como un ser específico. Segundo, la extracción de fragmentos puede considerarse como un acto violento, las células son arrancadas de su contexto de origen e introducidas en una nueva dimensión espaciotemporal cuyo resultado es, entre otras cosas, la pérdida de "vivacidad". Tercero, la mediación humana y tecnológica que debe existir para que los cuerpos extendidos puedan sobrevivir manifiesta una disminución en la capacidad autónoma de vivir que le confería el cuerpo de origen a cada uno de esos fragmentos.

Como parte del colectivo artístico The Tissue Culture and Art Project (TC\&A), el objetivo de Catts y Zurr respecto del cuerpo extendido es examinar las nuevas taxonomías y relaciones con el mundo de lo vivo y lo semi-vivo. A partir de sus obras desean construir un enfoque no antropocéntrico para comprender mejor los procesos y necesidades de estas entidades complejas que no son humano, ni no-humano, sino más bien seres semi-vivos. Esta propuesta implica una cantidad de cuestionamientos de orden ontológico que los autores enuncian de la siguiente manera

¿Tiene la vida un valor intrínseco diferente del valor de la novida? ¿Es la vida diferente de la no-vida en el sentido de que un sujeto es más que un objeto? (...) ¿Dónde se pueden colocar la vida parcial y los semi-vivos en las listas ontológicas y taxonómicas? ¿Tienen todavía los fragmentos de un individuo, aun estando en otros sitios geográficos, la esencia de ese individuo? ¿o son todos fragmentos de una misma 
especie? ¿Es el soporte tecnocientífico el que hace de los fragmentos "un cuerpo/comunidad" y un "ser"? ${ }^{36}$

Una de las obras que mejor representa el concepto de cuerpo extendido es NoArk (No Arca) de TC\&A. ${ }^{37}$ Se trata de una instalación formada por una estructura giratoria de gran tamaño que alberga en su interior una colección de animales muertos disecados en contraste con un biorreactor donde crece una biomasa compuesta por tejidos y células vivas disociadas que conforman un neo-organismo, un semi-ser que no existe en los libros de taxonomía ni en las clasificaciones culturales [figuras 1 y 2]. NoArk representa una ruptura con la taxonomía de Linneo y con la sistematización molecular al exhibir un semi-ser compuesto por fragmentos de cuerpos de diferentes organismos y tejidos que desafían las jerarquías científicas y sociales. Este cuerpo extendido no representa de modo alguno un orden fijado científicamente sino más bien se trata de una visión dúctil, artística y conceptual de aquella vida que es mediada técnicamente. Por ejemplo, una de las líneas celulares que compone NoArk se denomina McCoy cuyo origen se creía humano pero resultó ser de ratón. ${ }^{38}$ Las células McCoy están diseminadas por los laboratorios de todo el mundo viviendo de forma independiente y externa a su cuerpo de origen animal a través de la mediación tecnológica (en incubadoras, estufas, biorreactores, freezers o criogenizadas). Actualmente estos semi-seres, como las células McCoy, están fuera de los laboratorios e incorporados al ámbito artístico para posibilitar la reflexión, el cuestionamiento y la reevaluación de las relaciones humanas con el mundo vivo.

\footnotetext{
${ }^{36}$ Ibid., p. 6.

37 Texto incluido en el video de presentación de la obra a los premios VIDA 10.0 de Fundación Telefónica http://www.fundacion.telefonica.com/es/at/vida/popUpPremiados/shtml/02 noark.shtml

${ }^{38}$ Para la obra exhibida en la Bienal de Artes Electrónicas de Perth en 2007, se cultivaron células McCoy sobre polímeros. Los científicos afirmaban en 1965 que el origen de esta línea celular era humano y se encontraba en el líquido sinovial de la rodilla de un paciente con artritis degenerativa. Sin embargo, otras investigaciones determinaron que era de origen animal porque poseía los cromosomas marcados característicos de los fibroblastos torcidos del ratón L.
} 
Con un enfoque similar al trabajo del TC\&A, se encuentra la artista Orlan con una obra desarrollada en la Universidad de Western Australia (UWA) llamada Harlequin Coat, que continúa la serie de obras basadas en la transformación, mutación e hibridación de la identidad de la artista.

Desde la década del sesenta Orlan trabaja con su cuerpo para dar a conocer las ideas y opiniones que tiene respecto del arte, la sociedad y la cultura. En 1994 comenzó con una serie fotográfica llamada Self-hybridization (Autohibridación) que luego llevó a la escultura y la instalación. En la primera serie de fotos manipuladas digitalmente denominada Self-Hybridizations In-between ${ }^{39}$ se observa el rostro de Orlan mezclado con el rostro de algunas obras pradigmáticas de la historia del arte como el rostro de La Gioconda o de la Venus de Boticelli. En 1998 creó la serie Self-Hybridizations PreColumbian donde tomó algunos objetos cerámicos y escultóricos de América precolombina y los combinó con su rostro. En el 2000 realizó un grupo de esculturas que parodiaban su propio cuerpo, lo representó de color negro, con tres senos, tatuajes y marcas en su piel que provenían de comunidades africanas. Esta temática la continuó entre el 2002 y el 2003 con el trabajo fotográfico Self-Hybridizations Africancuyo rostro fue manipulado digitalmente para ser mezclado con los rostros típicos de distintas etnias del África. De igual modo, las primeras comunidades indígenas de América del Norte son retratadas desde el 2005 hasta el 2008 en SelfHybridizations American-Indian [ver Orlan antecedentes].

Todas estas mezclas de culturas, épocas y razas llevadas a cabo de manera virtual se volvieron reales en 2007 cuando la artista decidió hacer uso de la biotecnología para crear sus seres hibridados. Con ayuda del laboratorio de artes biológicas SymbioticA

\footnotetext{
${ }^{39}$ Self-Hybridizations In-Between es el nombre de la serie fotográfica en inglés y Self-Hybridation Entredeux es el título en francés. Tanto el término in-between como entre-deux no tienen traducción exacta al castellano, se refiere a algo que no es ni una cosa ni la otra, que está en el medio, entremedio de, intermedio.
} 
produjo Harlequin Coat (Traje de Arlequin), un cuerpo extendido formado por la combinación de células epiteliales provenientes de donantes de distinto origen, edad, sexo y color de piel. En un acto performativo que remitía a la "Reencarnación de Santa Orlan" ${ }^{40}$, la artista se sometió en una de las salas de cirugía de la UWA a la extracción de células de su piel [figura 3] para que fueran cultivadas in vitro junto al resto de las células donadas. Mientras realizaban la biopsia, Orlan leía pasajes del texto "Laïcité" de Michel Serres quien toma a la figura del arlequín como metáfora de hibridación, mestizaje y multiculturalismo [figura 4]. Según Serres, la túnica del arlequín es una yuxtaposición de retazos de distintos tamaños, colores, edades y procedencias que es posible trasladar al conjunto de la sociedad que se define, por esencia, como mestiza a partir de las mezclas genéticas, lingüísticas y culturales.

Durante más de cuatro décadas las performances, instalaciones, esculturas, fotografías y poesías de Orlan han cuestionado los aspectos que definen al ser humano: el género, la etnia, la religión, la belleza o la fisonomía. La artista aparece en sus trabajos de manera voluntaria disolviendo y volviendo a configurar su identidad en obras que mutan y cambian de manera permanente.

El desarrollo de Harlequin Coat apunta a reflexionar sobre las propiedades y capacidades tanto del ser como del semi-ser, algunas preguntas que se desprenden de esta obra son ¿Se pueden cultivar las células provenientes de pieles de distinto color? ¿Las propiedades de uno mismo continúan existiendo en un nivel fragmentado?

\footnotetext{
40 Entre 1990 y 1993, Orlan se sometió a siete operaciones de rostro para producir La obra maestra absoluta: la reencarnación de Santa Orlan. Cada operación, comenta Mark Dery, constituyó una performance: "la paciente, el cirujano y las enfermeras llevan trajes de alta costura, diseñados en algún caso por Paco Rabanne, y la sala de operaciones está adornada con un crucifijo, frutas de plástico y enormes carteles con los nombres de los patrocinadores de la operación (...). El comportamiento de Orlan, que se encuentra solamente bajo anestesia local, se parece más al de una directora en un plató de cine que al de una paciente". Dery, M. (1998). Velocidad de escape. Madrid: Siruela, p. 265.
} 
¿Cómo se perciben estas cuestiones en los diferentes países, y en especial, en el marco de una perspectiva no occidental ${ }^{41}$

El semi-ser de Harlequin Coat [figuras 5 y 6] compuesto de fragmentos de cuerpos propios y ajenos a la artista- alude explícitamente a la mezcla de razas, sexos y culturas, una idea que intenta desestabilizar por un lado las clasificaciones que rigen en el mundo actual de la biología y la cultura, y por el otro, promover en la sociedad la aceptación de una integración híbrida [ver ].

La obra Inmortalidad de Joaquín Fargas cumple el deseo de trascender la existencia humana al abolir el proceso de envejecimiento y muerte. Basada en la ambición del hombre por proyectarse hacia al futuro hasta superar su propia finitud, el artista generó un conjunto orgánico que se convierte metafóricamente en un corazón cuyo objetivo es permanecer latiendo indefinidamente.

Para la realización del cultivo celular que compone Inmortalidad se estudiaron distintos tipos de células, algunas cancerígenas consideradas "inmortales" por carecer de la información genética necesaria para envejecer y morir; otras provenientes de corazón de vizcacha, animal que presenta poliovulación y neo-oogénesis ${ }^{42}$ a edad adulta que simboliza la concepción de vida continuamente en contraposición a la muerte; y otras denominadas mioblastos procedentes del miocardio de embrión de rata que exhibe la propiedad de latir continuamente. Finalmente, los miocardiobalstos de rata fueron las células elegidas por su cualidad de latir y sincronizarse entre sí sin necesidad de intervención externa ya que es una propiedad intrínseca de las mismas [figuras 7 y 8].

El proyecto original consta de tres partes: cultivo celular, biorreactor y sistemas multimediales-espaciales. La combinación de las mismas permite generar un sistema

41 Extraído del catálogo de la Bienal de Artes Electrónicas de Perth, BEAP 2007, "Stillness", Perth, Australia.

${ }^{42}$ Formación de un óvulo. 
orgánico complejo, un semi-ser que late indefinidamente. Hasta el momento se han desarrollado parcialmente las dos primeras partes, por tal motivo la obra exhibida en 2008 en el Centro Cultural Recoleta se tituló Inmortalidad - Fase 1 [figura 9].

NoArk, Harlequin Coat e Inmortalidad reflexionan sobre los mismos temas que la ciencia y la filosofía: el ser vivo, la vida, la muerte, pero lo hacen de manera diferente. Esto es posible, según Nelson Goodman, porque no existe un solo modo -un único mundo- de acceso al estudio y conocimiento de las cosas, sino varios mundos que se hacen por medio de la verdad literal y también a través de lo que se dice metafóricamente:

En un tratado científico, la verdad literal tiene un papel máximo, pero en un poema o en una novela pueden pesar más la verdad metafórica o alegórica, ya que incluso un enunciado literalmente falso puede ser metafóricamente cierto. ${ }^{43}$

Quizás lo que la ciencia y la filosofía no pueden acceder por la vía de la razón teórica, la obra de arte sí puede hacerlo al poseer la capacidad de construir realidades ficcionales y aludir a verdades metafóricas. En este sentido Kant considera que algunos temas metafísicos como la muerte, el tiempo o Dios son inaccesibles para la razón teórica, sin embargo la ficción puede proporcionar un camino hacia ellos y ser soporte para la especulación filosófica.

El bioarte en tanto práctica artística en cruce con la biología y la filosofía explora la cuestión del ser, el individuo, lo vivo, lo no vivo y se anima a introducir una nueva categoría: la de lo semi-vivo, es decir, la construcción de un semi-ser, un ser disgregado, un cuerpo extendido y tecnocientífico que permite vincularse, pero al mismo tiempo discutir con la práctica científica y la reflexión filosófica.

${ }^{43}$ Goodman, N. (1978/1990). Maneras de hacer mundos. Madrid: La balsa de la medusa, p.39. 


\subsection{Acerca de la discusión estética sobre el bioarte}

Hasta aquí hemos caracterizado al bioarte como un arte viviente, esto implica la producción y exhibición de obras que presentan organismos vivos manipulados a nivel nuclear o celular. Este uso de técnicas y métodos científicos basados en la biotecnología genera una inestabilidad discursiva que pone en crisis no sólo los límites entre arte y ciencia, sino también el estatuto de obra, la figura de autor y el horizonte de expectativas del espectador que ahora se enfrenta a una obra de arte contemporáneo.

Es importante determinar las especificidades estéticas del bioarte a partir de la estrecha relación que mantiene con la ciencia, puesto que retoma el discurso y las prácticas científicas pero no con un fin cognoscitivo o utilitario sino artístico. Sin embargo, podríamos preguntarnos ¿Cómo se comunica el discurso científico, qué elementos de las ciencias biotecnológicas son transformados, qué funciones científicas originales se pierden a raíz del bioarte? Estos cuestionamientos que apuntan a la noción de creación de la obra se vinculan con otras problemáticas que refieren a la materialidad de la obra, es decir, a la utilización de seres vivientes. Es en este sentido que el bioarte establece una profundización de la crisis de la estética tradicional al proponer obras que no son continuas ni permanentes, por el contrario, plantean una autotransformación y una temporalidad variable dada por los ciclos de vida de los organismos y por los distintos momentos en que transcurre la obra. Autores como Arthur Danto, Gérard Wajcman, Georges Didi-Huberman, Nicolas Bourriaud, Nelson Goodman, Terry Smith y Marc Jiménez destacan la importancia del carácter conceptual, experiencial y procesual de la obra contemporánea.

La obra ya no puede ser definida, por sus cualidades materiales (colores, pigmentos, formatos, empastes) ni por su duración continua en el tiempo. En este sentido, la 
estrecha relación entre bioarte y ciencias biotecnológicas puede ser analizada desde la perspectiva de Danto en La transfiguración del lugar común sobre los cuestionamientos que plantea a la reflexión estética el carácter indiscernible de la obra contemporánea respecto de un objeto común, en este caso sería respecto de la práctica llevada a cabo por un investigador científico. Por su parte, Marc Jiménez destaca que los múltiples vínculos que mantiene el arte actual con las nuevas tecnologías, tales como la informática y la tecnociencia, llevan a la supresión de las fronteras entre disciplinas tornando difícil la especificación de la actividad artística. ${ }^{44}$ La obra contemporánea, y en especial la obra de bioarte, se presenta como experiencia, como acontecimiento efímero que va más allá de su materialidad. El carácter artístico parece estar dado por las relaciones que establece con los lugares de exhibición, las críticas, las reseñas, los manifiestos, los textos de artistas; más que por la propia materialidad de la obra que, dado su carácter vital, se vuelve efímera.

A esta clase se la denomina "art in progress" o arte procesual, como señala Bourriaud se trata de un arte que está más interesado en exponer los procesos o situaciones que en buscar un resultado final acabado: "Si observamos las prácticas artísticas contemporáneas, más que las 'formas', deberíamos hablar de 'formaciones', lo opuesto a un objeto cerrado sobre sí mismo por un estilo o una firma." ${ }^{45}$ De este modo, las obras que se presentan en etapas o fases a través de instalaciones y performances generan una dialéctica con el espectador que se basa no sólo en la mirada sino en la experiencia del que mira la obra y en lo que la obra le devuelve. Didi-Huberman, nombra a esta relación de copresencia entre espectadores y obras "lo que vemos, lo que nos mira" ${ }^{46}$, donde la obra se nutre de la experiencia del espectador que es mucho

\footnotetext{
${ }^{44}$ Jiménez, M. (2005/2010). La querella del arte contemporáneo. Buenos Aires: Amorrortu, p. 257.

${ }^{45}$ Bourriaud, N. (2006). Estética relacional. Buenos Aires: Adriana Hidalgo, p. 22.

${ }^{46}$ Didi-Huberman sostiene que las imágenes auténticas son aquellas que son dialécticas: son imágenes que critican a la imagen que se está mirando, que ponen en crisis las maneras de verla, que nos obliga a
} 
más activo pues ya no se posiciona frente o alrededor de esta sino por el contrario se sitúa en y dentro dela obra, desde lo intelectual hasta lo corporal.

Esto no puede dejar de vincularse con el giro hacia el receptor de las estéticas del siglo XX y la noción de obra como obra abierta. Las concepciones de la recepción entendida como contemplación de un absoluto que se manifiesta en la obra (por ejemplo en concepciones románticas como la de Schopenhauer o en la concepción hegeliana) resultan cuestionadas en gran parte como consecuencia del giro de la hermeneútica de Heidegger, así como por las perspectivas de W. Benjamin y Sartre, entre otros. Autores como Gadamer y luego Ingarden, Jauss o Eco, pueden inscribirse dentro de lo que se denomina estéticas de la recepción. En líneas generales esto significa el paso del ideal substancialista de la obra como portadora de verdad, a la idea de que la obra no es nada sin la recepción, esto es, lo que hay son concretizaciones de sentidos dados en cada caso por el encuentro entre una estructura previa propuesta por la obra y la interpretación del receptor. ${ }^{47}$

Gran parte de la producción artística contemporánea, entonces, se basa en un intercambio o encuentro y por tanto requiere de la participación del público que puede ejercer diversos roles como testigo, invitado, intruso, protagonista, coproductor.

En general el arte contemporáneo también pone en crisis la figura de artista o autor, ligada a una noción moderna de subjetividad, esto es, a un sujeto concebido como dueño de sí y de la naturaleza. Desde el punto de vista filosófico la crítica más fuerte a ese modelo moderno de subjetividad proviene de Heidegger ${ }^{48}$, sin embargo también fue cuestionado por autores como Marx, Freud y Nietzsche. En el siglo XX los

mirarnos para volver a mirar nuevamente la imagen de otro modo. Las imágenes auténticas son las que devuelven la mirada. Didi-Huberman, G. (1992/1997). Lo que vemos, lo que nos mira. Buenos Aires: Manantial.

${ }^{47}$ Cf. Presas, M. (2001). "La recepción estética”. En D. Sobrevilla y J. Xirau (Ed.), Estética en Enciclopedia Iberoamericana de Filosofía. Madrid: Instituto de Investigaciones Filosóficas. Consejo Nacional de Investigaciones Científicas.

${ }^{48}$ Heidegger, M. (1938/2000). Caminos del bosque.Madrid: Alianza. 
estructuralistas y postestructuralistas como Saussure, Jakobson, Foucault, Kristeva y Barthes, coinciden en desestimar la existencia de un sujeto autónomo o un sujeto que se construye a sí mismo, sino que más bien las formas de subjetividad están determinadas por una estructura, una trama que lo precede. Por lo tanto, los estudios estructuralistas no se centran en el sujeto sino en aquello que crea esas formas de subjetividad. Ello conlleva a declarar, en ciertos casos como Foucault ${ }^{49}$ y Barthes $^{50}$, y en referencia a la literatura, la muerte del autor.

A esta muerte le acompañan otras producidas en el seno de las artes visuales tradicionales como la muerte de la pintura, la muerte del plano y hasta la muerte misma del arte. Daniela Koldobsky señala que en ese momento especial dado por las "muertes de" cae también la noción de obra y con ella la noción de artista vinculada principalmente al romanticismo. Cuando las condiciones de producción se transformaron hacia la década del sesenta debido a la influencia del dadaísmo y al abandono de dispositivos y soportes tradicionales como la pintura y la escultura, se modifica también la figura de artista que comienza a cumplir diversas funciones dentro de la obra como escribano, maestro de ceremonias o estrella del espectáculo, entre otros $^{51}$.

En el caso del bioarte, la estrecha relación que mantienen los artistas con los métodos y procedimientos de las ciencias biotecnológicas provoca la emergencia de nuevas figuras tal es el caso del artista-científico, el artista-investigador o el artista-divulgador. Como se sostuvo anteriormente, en un contexto general de crisis de fundamentos del arte, las fronteras de lo artístico se desvanecen y se vuelven sumamente problemáticas todas las distinciones o definiciones. En suma, las reconfiguraciones

\footnotetext{
${ }^{49}$ Foucault, M. (abril 1998). “¿Qué es un autor?”. Traducción: Silvio Mattoni. Título Original: Qu’est-ce qu'un auteur?. Conferencia en la Sociedad Francesa de Filosofía, publicada en el Bulletin de la S.F.P. julio-septiembre, 1969.

${ }^{50}$ Barthes, R. (1968/2009). "La muerte del autor" en El susurro del lenguaje. Barcelona: Paidós.

${ }^{51}$ Koldobsky, D. (2003). "La figura de artista cuando se anuncia su muerte", inédito.
} 
que propone el bioarte en contraposición a categorías desarrolladas por las estéticas ligadas a la modernidad y a cierto arte moderno, son la razón principal para el desarrollo de esta tesis. 
3. SOBRE EL CONCEPTO DE OBRA 


\subsection{Obras modernas y contemporáneas}

La obra de arte moderna no es igual a la obra de arte contemporánea. ${ }^{52}$ Aunque se asemeje visualmente con aquella o exponga los mismos temas, no lo hace de igual manera. La obra de arte moderna, sobre todo la pictórica, es netamente local, materialista y opaca, deja a un lado la mimesis y la representación para evidenciar los materiales (pigmentos, empastes, formas) que son el objeto de su representación. El arte moderno marca un estilo particular identificable con estos principios que posibilitan introducir la pregunta acerca de la propia ontología de la pintura "de cómo la pintura fue posible." ${ }^{53}$

La constante búsqueda y experimentación con materiales nuevos iniciada por los artistas de vanguardia, llevó a presionar cada vez más los límites que el mismo arte moderno había establecido, a punto tal que cualquier cosa podía ser considerada una obra de arte. Las obras podían ser imaginadas o producidas con objetos reales (objetos-comunes-cualquiera ${ }^{54}$ ) que no exigían estatus de arte, dando lugar a la

\footnotetext{
${ }^{52}$ Arthur Danto construye una periodización que divide a la Era Moderna en dos períodos, uno constituido por una narrativa premoderna en la cual "los pintores se dedicaban a la representación del mundo pintando personas, paisajes y eventos históricos tal como se les presentaban o hubieran presentado al ojo" (p. 29). Este período se corresponde con una narrativa mimética que se origina en el Renacimiento (siglo XV) culminando hacia 1880 con la aparición del post impresionismo. Por esta razón, Van Gogh y Gauguin son los primeros pintores modernos que dan inicio al período denominado narrativa moderna o no mimética y que culmina en 1960 con el inicio de la Era Poshistórica. Si bien para Danto entre 1970 y 1980 el arte contemporáneo determina su estructura de producción artística en contraposición a la resuelta por el arte moderno, la mayor parte de los cambios se originan hacia 1960 con la concepción de un tiempo y un espacio diferente en la obra, introducido por los happenings, las performances, las instalaciones y las ambientaciones. Danto, A. (1997/2009). Después del fin del arte. Buenos Aires: Paidós.

${ }^{53}$ Ibid., p. 29.

${ }^{54}$ Gérard Wajcman reflexiona acerca de los objetos comunes, útiles e industriales, utilizados en el mundo del arte. Cuando ello sucede, el objeto común no es expulsado sino que es vaciado, se le sustrae su uso y su significación desterrando así su ser de objeto-común-cualquiera. En este proceder, se establece el pasaje de los objetos al objeto, es decir se pasa de objetos genéricos, plurales y comunes (ruedas de
} 
indefinición a priori de las propiedades constitutivas de una obra de arte. No había imperativos previos sobre las propiedades visuales particulares que una obra debía tener, sino que cualquier cosa podía ser obra de arte. Cuando una obra pudo consistir en cualquier objeto legitimado como arte surgió irremediablemente en ese contexto la pregunta por la naturaleza del arte ¿Por qué esto o aquello es una obra de arte? Para Danto con esa pregunta se terminó la historia del arte moderno centrado puramente en la materialidad y dio paso al arte contemporáneo. Es decir, que el cuestionamiento ya no pasaba por la ontología de la pintura, por caracterizar su esencia y naturaleza, sino por reflexionar sobre la ontología misma del arte, sobre su modo de ser.

La obra de arte contemporánea difiere de la moderna no sólo por el tipo de preguntas que realiza (reflexiona y piensa filosóficamente sobre el arte) sino también por su dimensión espacial y temporal, señala Bourriaud que "El arte de hoy nos obliga a pensar de manera diferente las relaciones entre el espacio y el tiempo: es lo esencial, allí reside su mayor originalidad" ${ }^{55}$. A la obra moderna permanente, continua y estática construida a partir del factor material le sucede la obra contemporánea basada en el proceso, el cambio y la experiencia.

La forma de la obra contemporánea se extiende más allá de su forma material: es una amalgama, un principio aglutinante dinámico. Una obra de arte es un punto sobre una línea. (...) El arte actual muestra que sólo hay forma en el encuentro, en la relación dinámica que mantiene una propuesta artística con otras formaciones, artísticas o no. ${ }^{56}$

Para Julian Stallabrass el arte contemporáneo es incomprensiblemente complejo y diverso. La variedad de formas, técnicas y temas en arte es desconcertante. Los

bicicletas) a un objeto singular, particular y artístico ("Rueda de bicicleta”). Wajcman, G. (1998/2001). El objeto del siglo. Buenos Aires: Amorrortu.

${ }^{55}$ Bourriaud, N. Op. cit., p. 58.

${ }^{56}$ Ibid., pp. 21-22. 
soportes $^{57}$ tradicionales como la pintura, la escultura y el grabado han sido superpuestos por la instalación, los nuevos medios (que abarcan desde el arte online hasta ambientes sonoros controlados digitalmente) y la performance, formatos que se vinculan tanto con lo espacial como con lo temporal dado por lo efímero, lo actual y lo procesual. En el caso de la instalación, Stallabrass indica que por definición es un arte efímero que se resiste a la compra y a la venta. ${ }^{58}$ Nacida en los sesenta como environment art (arte ambiente) se convirtió en una nueva opción de creación en los espacios gestionados por los artistas. En la década del ochenta fue impulsada al mercado del arte como propuesta alternativa de producción artística para establecerse finalmente en los museos hacia la década de los noventa. Aunque es considerada un arte más espacial que temporal, la instalación incluye habitualmente aspectos temporales al incluir video, nuevos medios y elementos de la performance.

Bourriaud destaca como rasgo esencial de la obra de arte contemporánea su nodisponibilidad. A diferencia de las pinturas o esculturas modernas que se caracterizan por su disponibilidad permanente (más allá de imposibilidades evidentes como horarios de museos, distancias geográficas u otro tipo de restricción) este tipo de obras pueden ser vistas en cualquier momento "está a la vista, disponible para la curiosidad de un público teóricamente universal" ${ }^{59}$. La obra contemporánea es a menudo no-disponible, se muestra en un momento determinado y una vez que sucedió solo queda su documentación. El ejemplo más claro es la performance, que ya no se ofrece en el marco de un tiempo "monumental" ni está abierta para un público universal, sino que se lleva a cabo en un momento determinado para un público

\footnotetext{
${ }^{57}$ Según el caso, hacemos referencia a soportes, otras veces a dispositivos, y en otras a modos de exhibición. La diferencia varía según el autor abordado o si se atiende exclusivamente al aspecto técnico, a la mediación social o a la circulación de la obra.

${ }^{58} \mathrm{Sin}$ embargo, aclara el autor, hoy en día la instalación se mueve y se paga; además, es utilizada regularmente por artistas y marchands como cebo para vender productos más comercializables. Stallabras, J. (2004/2006). Contemporary Art. A very short introduction. New York: Oxford.

${ }^{59}$ Bourriaud, N. Op. cit., p. 32.
} 
invitado por el artista. ${ }^{60}$ La obra preformativa no está fija ni es permanente, establece horarios, da citas, propone encuentros: la obra administra su propia temporalidad.

Un último aspecto acerca de la complejidad de la obra contemporánea es la variabilidad e inestabilidad que propone específicamente la obra de bioarte al mutar permanentemente debido a sus condiciones biológicas. Como cualquier ser orgánico las obras de bioarte exigen un tiempo de gestación que suele hacerse en etapas o fases y que varía su duración de acuerdo a cada proyecto. Las investigaciones científicas que se necesitan para generar una obra pueden durar semanas, meses o años. Tagny Duff estuvo alrededor de un año trabajando en el laboratorio para conseguir que el retrovirus infecte al cultivo tisular para poder desarrollar Living Viral Tattoos; los científicos que asisten a Joaquín Fargas siguen probando células cardíacas de distintas especies para generar la autonomía de Inmortalidad; y Beatriz Da Costa realizó numerosos workshops intentando producir sensores de contaminación biológicos; en cambio Eduardo Kac solicita a los laboratorios a través de un e-mail sus cultivos transgénicos que son reenviados por correo postal en pocas semanas; o lonat Zurr y Oron Catts apelan a su colección de líneas celulares congeladas para ser replicadas y utilizadas inmediatamente si una obra lo requiere.

Por otra parte la duración de la obra dependerá fundamentalmente del tiempo de vida que variará según el organismo, las condiciones ambientales de temperatura, oxígeno y humedad, el cuidado y asistencia del personal, o la interacción con los espectadores. De este modo las obras de bioarte van cambiando, creciendo, evolucionando, e incluso, muriendo.

Algunos casos sobre cambio, mutación y duración del bioarte, son las obras de Luciana Paoletti quien trabaja con bacterias y hongos para realizar sus Pinturas [figura

\footnotetext{
${ }^{60}$ lbid., p. 32.
} 
10]. Para ello aísla los microorganismos, los selecciona, los reproduce y con estos dibuja sobre placas que contienen el medio de cultivo. Cuando las bacterias y los hongos crecen, aparece una imagen que la artista fotografía para luego exhibir, pues los microorganismos mueren al consumirse los nutrientes. ${ }^{61}$ Otro ejemplo es Plantas Nómadas de Gilberto Esparza, una obra compuesta por un sistema robótico programado para cada tipo de terreno y medioambiente, una planta vegetal orgánica y un conjunto de celdas de combustible microbianas y fotovoltaicas [figura 11]. Este organismo híbrido se nutre de agua contaminada que procesa en sus celdas de combustible a través de una colonia de bacterias autóctonas provenientes del mismo agua que transforma los nutrientes en electricidad y energía. En este proceso de biodegradación se mejora la calidad del agua que nutre a la planta orgánica y que, a su vez, también produce energía liberando oxígeno al planeta. Plantas Nómadas varía de acuerdo a las condiciones medioambientales a las que se exponga, se modifica según el lugar por donde transite y su ciclo de vida dependerá de las bacterias utilizadas así como de los procesos de biodegradación del agua que alimenta a la planta natural [ver ]. En Genesis de Eduardo Kac se presenta un cultivo celular retroproyectado sobre una pared donde se pueden observar puntos de color azul y amarillo que son las bacterias transgénicas [figura 12]. Los espectadores pulsan una luz ultravioleta para iluminar el cultivo lo que provoca la mutación de las bacterias de modo que la imagen proyectada nunca es estable, los puntos varían -a veces predominan los azules en otros los amarillos- crecen, decrecen, se yuxtaponen, se separan y cambian de forma. Otro caso de transformación de la obra es Workhorse Zoo de Adam Zaretsky, una performance de una semana de duración que incluye todo tipo de organismos utilizados en la investigación biotecnológica: bacterias (Escherichia

\footnotetext{
${ }^{61}$ Entrevista a la artista extraída del sitio http://ludion.com.ar
} 
coli), levaduras (Saccharomyces cerevisiae), plantas (Arabidopsis thaliana), gusanos (Caenorhabditis elegans), moscas (Drosophila melanogaster), peces (Danio rerio), ranas (Xenopus laevis) y ratones (Mus musculus). El artista se encerró en un cuarto aséptico transparente con todos estos organismos en el interior del Salina Art Center en Kansas y luego de una semana de convivencia algunos organismos se habían multiplicado, otros habían fallecido naturalmente y otros habían sido devorados por predadores o cocinados por el propio artista para alimentarse [figuras 13 a 16].

En este sentido, el bioarte establece una profundización de la crisis de la estética moderna al proponer obras que no son continuas ni permanentes, por el contrario, plantean una autotransformación y una temporalidad variable dada por los ciclos de vida de los organismos y por los distintos momentos en que transcurre la obra (fases de desarrollo, performance, instalación, registro). El problema de la inestabilidad de las obras de bioarte se traslada también al museo, un ámbito que nace del pensamiento moderno, al cuestionar los aspectos tradicionales de colección, conservación y exhibición.

TC\&A y el caso del MoMA

En 2008 la curadora del Museo de Arte Moderno de Nueva York (MoMA) Paola Antonelli realizó una muestra poco habitual para ese museo denominada Design and the Elastic Mind (Diseño y la Mente Elástica) donde se presentaban obras vinculadas al diseño y su intersección con otras áreas como la biología, la ingeniería o la arquitectura. La mayoría de los trabajos eran objetos realizados en coautoría o coparticipación entre diseñadores/artistas y científicos. El colectivo de artistas australianos TC\&A participó con dos obras Victimless Leather (Cuero sin Víctimas) y The Pig Wings Project (El Proyecto Alas de Cerdo). 
Victimless Leather es un pequeño tapado de piel realizado justamente a partir del cultivo tisular de células aisladas, es decir, que ningún organismo tuvo que ser sacrificado para dar origen a esta prenda sino que las células extraídas del animal fueron cultivadas sobre una matriz polimérica biodegradable hecha con la forma de un tapado [figura 17]. El biorreactor que mantenía vivo al cultivo fue inspirado en la bomba de perfusión de órganos originalmente diseñada por Alexis Carrely Charles Lindbergh. Se trataba de un sistema de goteo automático que gotea nutrientes en los polímeros y alimenta a las células que crecen tomando la forma de la prenda [figura 18].

El concepto artístico implicado en esta obra aborda cuestiones que van más allá de lo estético o lo visual, implica la confrontación de personas que están a favor o en contra del uso de animales muertos como indumento; el trato ético, moral y social del Otro; y el vínculo subjetivo con la manipulación de sistemas vivos. La idea del TC\&A no es realizar un producto de consumo sino plantear algunas preguntas sobre la explotación de los seres vivos y el efecto de estas nuevas formas en la percepción cultural sobre la vida ya que Victimless Leather sea, probablemente, la manifestación tangible de un futuro posible. Esta pieza representa irónicamente el precio de la tecnología, de cuánto deberá pagar una sociedad para lograr la utopía de tener tapados de piel sin víctimas. La obra transitó por un momento de tensión en el MoMA cuando el sistema de perfusión casi colapsa debido al rápido crecimiento de las células que obstruyeron los tubos de alimentación. El cultivo creció en forma más veloz de la que presuponía el museo provocando la caída de una de las mangas del tapado y el replanteo de mantener con vida la obra hasta el final de la exhibición. Luego de hablar con los artistas, la curadora decidió apagar el sistema automático para detener el flujo que alimentaba a la pieza. El diario The New York Times tituló este episodio "Museum Kills 
Live Exhibit” ${ }^{\prime 2}$ ya que el MoMA había matado a la única obra viva de la exhibición. La curadora admitió haberse sentido terriblemente cruel al desenchufar el sistema de alimentación pero no le quedó otra alternativa pues el museo no podía controlar el crecimiento de la obra.

La otra obra exhibida del colectivo artístico fue The Pig Wings Project ${ }^{63}$, una de las primeras en donde TC\&A experimentó con el cultivo de células sobre polímeros. El uso de células madre (embrionarias y progenitoras) aumenta el potencial de la ingeniería tisular para la fabricación de órganos complejos por fuera del cuerpo. El proceso de creación de esculturas realizadas a través de la ingeniería tisular comienza con la obtención de las células o tejidos deseados. Para Pig Wings Project los artistas recogieron células Mesenquimales (células madre de médula ósea) de cerdo $^{64}$ que aislaron por medios mecánicos y químicos [figuras 19 y 20]. Las células suspendidas crecieron en capas bidimensionales [figura 21] por cerca de cuatro meses para luego ser colocadas alrededor de las estructuras poliméricas con forma de alas [figura 22]. Otra técnica utilizada fue el cultivo de células dentro de cápsulas ubicadas en un biorreactor dinámico, es decir, un biorreactor giratorio que permite que las células se desarrollen en tres dimensiones. Los polímeros cultivados fueron alimentados durante seis meses dentro de cabinas de bioseguridad bajo condiciones estériles. A lo largo de ese tiempo el polímero fue degrado y reemplazado por el tejido vivo [figura 23].

La idea de trabajar con alas proviene de las quimeras que existieron a lo largo de la historia, cuerpos alados, cuerpos híbridos al igual que estas pequeñas esculturas vivas construidas con células provenientes de distintos orígenes. Los artistas diseñaron tres

62 Schwartz, J. (2008, 13 de mayo). "Museum Kills Live Exhibit". The New York Times. http://www.nytimes.com/2008/05/13/science/13coat.html? $r=0$

${ }_{63}$ El nombre original es Pig Wings Project pero en el catálogo del Moma figura como The Pig Wings Project.

64 Los tejidos primarios se obtienen exclusivamente de los restos de producción cárnica o de investigaciones científicas. 
pares de alas (que se corresponden con las tres soluciones para volar que tienen los vertebrados) las dos primeras tienen que ver con cargas simbólicas asignadas por la cultura como el bien y el mal, el bien vinculado a lo angelical y a las alas de los pájaros y el mal relacionado con lo satánico, lo vampiresco representado mediante alas de murciélago. El tercer par de alas carece de algún valor simbólico pero se eligió por pertenecer a uno de los primeros animales vertebrados en poder volar, el Pterosaurio. La primera exhibición de Pig Wings Project consistió en una instalación en proceso donde se podían observar varias cosas en simultáneo. En vitrinas transparentes [figura 24] se colocaron algunos elementos utilizados en la producción de las primeras alas de cerdo (batas, microscopios, frascos, pinzas, fotos del proceso de recolección celular, etc.), también había cultivos vivos que se estaban desarrollando en ese momento y que aparecían dentro de biorreactores comunes o dinámicos, además había una cabina de bioseguridad instalada en la sala donde trabajaban los artistas en el cultivo de células [figura 25]. La instalación se completaba con un microscopio digital que filmaba un cultivo que era proyectado en un monitor [figura 26], y el emplazamiento de tres tarimas que mostraban las cápsulas de petri con las estructuras aladas en su interior acompañadas por tres grandes fotografías enmarcadas [figura 27]. Las fotografías eran impresiones digitales de cada par de alas tomadas con un microscopio de fluorescencia. Este microscopio utiliza filtros especiales que permiten el paso de luz de una determinada longitud de onda a la vez que bloquea las longitudes no deseadas, de modo que se excitan los fluorcromos aplicados a cada cultivo y se obtienen así imágenes de color rojo, azul o verde.

En el marco de la muestra Design and the Elastic Mind presentada en el MoMA, el colectivo TC\&A presentó The Pig Wings Project. Pero lo que se exhibió exactamente no fue la realización de la performance donde se producían los cultivos en vivo, ni se 
expusieron los biorreactores con las estructuras aladas creciendo adentro, tampoco se montaron las tarimas con las cápsulas de petri que contenían a cada estructura alada semi-viva. Lo que el museo exhibió -y que luego adquirió para su acervo- fueron las tres fotografías enmarcadas [figura 28].

Este hecho se vincula con la crítica que realizó Terry Smith al MoMA en su intento de incluir al arte contemporáneo. Con motivo de la reapertura del museo en el 2004, los curadores del museo fueron extremadamente cautos a la hora de exhibir las obras de arte contemporáneo, la mayoría se correspondía con pinturas y esculturas, y en algunos pocos casos aparecían dibujos y películas.

El MoMA de 2004 no pudo hacer frente a la paradoja que de gran parte del arte contemporáneo más exitoso y resonante fuera conservador, carente de originalidad y seguro, por el hecho de limitarse a actualizar procedimientos y gustos modernistas de manera seductora, mientras que el arte contemporáneo de ruptura, original y desafiante, lo era precisamente por su capacidad de desafiar esos mismos procedimientos y gustos. En las exhibiciones programadas para su reinauguración, el MoMA eligió dar prioridad a aquellas obras contemporáneas que todavía eran modernas, al menos en estilo y apariencia. ${ }^{65}$

Smith continuó analizando las muestras de la sala contemporánea desde 2005 hasta el 2007 y la conclusión siempre es la misma: las exhibiciones que realiza el MoMA, las obras que elige, la forma de mostrarlas "sobre las paredes", pertenencen a un horizonte remodernista que implica que las obras se lean como contemporáneamente modernas o modernistas contemporáneas. ${ }^{66}$ El crítico Michael Kimmelman no fue menos severo en sus declaraciones y consideró a la muestra exhibida entre fines de 2006 y principios de 2007 "tan ortodoxa, tan fiel al acervo genético minimalistaconceptualista, tan leal al elenco familiar de artistas legitimados de antemano y tan

\footnotetext{
${ }^{65}$ Smith, T. (2009/2012). ¿Qué es el arte contemporáneo?. Buenos Aires: Siglo XXI, p. 46. ${ }^{66}$ Ibid., p. 56.
} 
adversa al riesgo, tan incapaz de aceptar la excentricidad, que hace que el arte parezca estático y aislado, como una liebre sorprendida por los faros de un auto." ${ }^{17}$ Pese a los intentos por exhibir obras contemporáneas, entre ellas obras vivientes, finalmente el MoMA no pudo hacerse cargo de la espontaneidad y el azar que genera la inclusión de obras que crecen, mutan y se transforman permanentemente. En el caso de Victimless Leather el museo decidió dar por concluida la obra al desconectarla del aparato que la mantenía con vida. En tanto que con The Pig Wings Project se decidió por lo seguro y tradicional al exhibir imágenes enmarcadas colgadas sobre la pared. Como señala Smith, si se desea ser considerado un museo contemporáneo debe abrirse espacio para todo tipo de eventos, debe ser un lugar preparado y listo para cualquier cosa que le ocurra. ${ }^{68}$

\subsection{Obras híbridas e hibridaciones}

La mayoría de las obras de bioarte son definidas como seres híbridos, mixtos o quimeras, gracias a la combinación de elementos naturales con otros de origen tecnológico, ubicándose en la intersección entre los sistemas biológicos reales y los sistemas tecno-artificiales. Lo interesante de estas producciones que manifiestan transacciones, intersecciones y diálogos entre disciplinas, es que el concepto mismo de hibridación se presenta como un fiel exponente de tal interdisciplinariedad.

Mieke Bal considera que los conceptos juegan un papel crucial en el tráfico entre disciplinas gracias a dos consecuencias inherentes a su capacidad de propagar, fundar y definir un campo de objetos: por una parte, fusionan la epistemología y la práctica científica al capturar la cientificidad de la metodología que sostienen; y en el

\footnotetext{
${ }^{67}$ Kimmelman en Smith, ibid., p. 54.

${ }^{68}$ Ibid. p. 55.
} 
sentido opuesto, consiguen "endurecer" la ciencia en cuestión, al determinar y restringir lo que cuenta como científico. ${ }^{69}$

La variación en el significado de los conceptos ocurre porque nunca están fijos, viajan en el tiempo y el espacio atravesando disciplinas, investigadores, comunidades académicas separadas geográficamente y períodos históricos diversos. ${ }^{70}$ En estos viajes el significado y el uso de los conceptos pueden cambiar radicalmente tal como ocurrió con el concepto de hibridación que ha estado fluctuando entre disciplinas y significados desde su origen en el siglo XIX donde apareció en las ciencias biológicas vinculado a un discurso totalitarista de fuertes connotaciones raciales; mientras que hoy en día se lo utiliza para designar la idealización de un estado postcolonial basado en la diversidad de culturas ${ }^{71}$.

Debido a los viajes interdisciplinarios, el concepto de hibridación se utiliza en este momento tanto en las ciencias biológicas como en las ciencias sociales. Con este término se hace referencia a pacientes trasplantados, comunidades culturales o nuevos medios de comunicación. En efecto, casi todas las áreas están atravesadas por algún tipo de hibridación, desde la política y la economía hasta la ecología, la tecnología o el arte presentan algún tipo de mixtura. Se puede considerar que las producciones de nuestra cultura no son puras, están plagadas de préstamos, apropiaciones, alusiones, citas y comentarios. Es una cultura del pastiche y del bricolage que mezcla, combina y fusiona elementos provenientes de distintos orígenes. Así se presenta y se celebra el concepto de hibridación en la contemporaneidad: como copresencia de elementos diversos que vuelven borrosa cualquier división.

\footnotetext{
${ }^{69}$ Bal, M. (enero 2006). "Conceptos viajeros en las humanidades”. Estudios Visuales, (3), 28-77, p. 44.

${ }^{70}$ Ibid., p. 31

${ }^{71}$ lbid., p. 31.
} 
En el campo del arte y los medios Manovich considera que las nuevas tecnologías basadas en el código numérico son las responsables de la revolución del híbrido. La informática vuelve virtual a las cosas sacándolas de su medio físico de origen para transformarlas en algoritmos, una vez ocurrido esto, es posible manipular, modificar y combinar los elementos a gusto generando un remix permanente. Lo que se remixa no es sólo el contenido de los distintos medios sino sus técnicas, métodos de trabajos, formas de representación y expresión, esto es lo que Manovich considera un remix profundo, la esencia de la revolución del híbrido. ${ }^{72}$ Es decir, la conversión de medios puros (fotografía, cinematografía, animación, gráfica 3D) en medios híbridos o metamedium: medios que usan una o todas las técnicas que antes pertenecían exclusivamente a cada uno de los medios puros.

Lo interesante de los medios actuales, señalan autores como Machado y Bellour, no está puesto en la individualidad y delimitación de cada uno (en su forma de actuar separada e independientemente de los otros) sino por el contrario en las conexiones, intersecciones y convergencias que existen entre medios "lo que hay de un medio en otro: qué hay de pintura en el cine, de cine en la literatura, de fotografía en la música, de televisión en el video."73 Las fronteras entre soportes, medios y lenguajes se disfuman generando así producciones híbridas, mestizas, compuestas de fuentes diversas. Algunas veces es posible determinar la naturaleza de cada una de estas en la medida en que los elementos constitutivos del híbrido se presentan de manera yuxtapuesta. Por el contrario, si los elementos se fusionan de manera profunda ya no es posible determinar el origen de las fuentes y las diferencias se vuelven invisibles.

\footnotetext{
72 Manovich, $\quad$ L. (2007). “Understanding Hybrid Media”. $\quad$ En http://www.manovich.net/DOCS/ae with artists.doc. Traducción: Eva Noriega y Melissa Mutchinick, FBAUNLP.

${ }^{73}$ Machado, A. (2006) “Convergencia y divergencia de los medios”. Revista Miradas. La Habana: EICTV.
} 
Sin embargo, la hibridación involucra algo más que la mezcla de elementos de manera visible o invisible, implica el encuentro de orígenes y naturalezas dispares reunidos de manera tal que sus diferencias se intersectan en algún punto; y es allí, en esa zona fronteriza en donde se ubica tanto el conflicto como la conciliación. ${ }^{74}$ Por eso la hibridación no deja de ser un aspecto tensionante dentro de la cultura contemporánea, ya sea promoviendo la integración o generando fricciones, oscilando entre la unicidad dada por la suma de las partes que generan algo totalmente nuevo, y la multiplicidad provocada por el apilamiento y la superposición visible de cada uno de sus elementos de origen, el híbrido se manifiesta de diversos modos.

Por esta razón, las obras de bioarte consideradas híbridas manifiestan esos modos en que es posible pensar a la hibridación en la actualidad, ya sea como integración, conflicto, yuxtaposición, fusión, multiplicidad o unicidad.

\section{Integración}

La obra Biological Bespoke de Amy Congdon representa una suerte de integración de las ciencias biotecnológicas con el arte del diseño textil. Para ello, la artista utilizó diferentes métodos y procedimientos científicos para diseñar sus piezas vivientes hechas "a medida" ${ }^{75}$ que se basan en técnicas tradicionales de bordado. Partiendo del cultivo de células y de procedimientos que se utilizan en medicina reconstructiva, Congdon diseñó unas matrices poliméricas biodegradables con formas ornamentales que luego serían degradas y reemplazadas por cultivos celulares, dando como resultado un bordado viviente [figuras 29 y 30 ].

En este caso la integración del arte con la ciencia pone a prueba el futuro del diseño de indumentaria en cuanto a la elección de materiales y en tanto al trabajo

\footnotetext{
${ }_{74}^{74}$ García Canclini, N. (2007, 1 de julio). "La Argentina tiene muchas zonas de fricción”. Infobae.

${ }^{75}$ Biological Bespoke significa biología hecha a medida, en alusión a la alta costura.
} 
interdisciplinario, generando la posibilidad de trabajar en el taller textil así como también en el laboratorio con el fin de combinar fibras textiles con cultivos celulares.

\section{Conflicto}

El colectivo Critical Art Ensemble (CAE) se caracteriza por desarrollar obras que cuestionan la falta de ética política y científica con la que se llevan a cabo ciertas investigaciones en el campo de la ingeniería genética. GenTerra es una performance abierta al público para explorar en vivo la variedad de discursos acerca de la transgénesis en relación con el riesgo ambiental y la política de salud humana.

El discurso político y la ética científica entran en conflicto cuando se interpone el mercado económico. Para el CAE la investigación científica en biotecnología está tomando una actitud corporativa, capitalista, al analizar primero los beneficios y más adelante los riesgos. De ello se desprende que ciertos valores éticos y morales entran en tensión cuando son dejados a un lado a medida que la rentabilidad económica supera los posibles daños ambientales o de salubridad.

\section{Yuxtaposición}

Ear on the Arm de Stelarc es un claro ejemplo de hibridación en donde se combina lo natural con lo artificial en el sentido en que se yuxtapone una oreja sintética y un brazo humano. El artista accedió a someterse a una intervención quirúrgica para que le injertaran una prótesis con forma de oreja en su antebrazo izquierdo [figuras 31 y 32]. La prótesis utilizada era una réplica de su propia oreja izquierda y posee las características de ser biocompatible, fomentar el crecimiento fibrovascular, acoplarse al brazo en el sitio insertado y no permitir ningún tipo de desplazamiento. 
El proyecto de Stelarc era aún más ambicioso ya que propuso que la oreja extra no solo escuchara sino también transmitiera. En una segunda cirugía se incorporó un micrófono en miniatura que posibilitaba la captación y transmisión de los sonidos ambientes. Desafortunadamente una infección provocó que se le extrajera el micrófono colocado para salvar la prótesis. El resultado final de esta obra performativa [figura 33] es un apilamiento de tejidos orgánicos e inorgánicos que conviven simultáneamente en un mismo ser.

\section{Fusión}

May the mice bite me if it is not true ${ }^{76}$ es una obra de Verena Kaminiarz que explora el mundo de los animales de laboratorio creados como modelos de enfermedades humanas. La artista propuso mejorar la calidad de vida de cuatro ratones del laboratorio a los que le otorgó una identidad y un lugar agradable para vivir.

Los ratones son "retratos experimentales" y representan el retrato vivo de cuatro personas reconocidas en el campo del arte y la filosofía que han muerto a causa de la misma enfermedad que lleva cada modelo de ratón en su genoma. Los retratos resultantes [figura 34] aluden a Franz Kafka muerto por tuberculosis, Felix GonzalezTorres muerto por tener comprometido el sistema inmunológico (HIV), Joseph Beuys muerto por causas naturales y Gilles Deleuze quien decide suicidarse por tener comprometido el sistema respiratorio debido a un cáncer de pulmón.

Por medio de técnicas científicas las enfermedades humanas se integraron al genoma del roedor, y mediante el uso de recursos artísticos las identidades de estas cuatro personalidades se asociaron a la vida de los ratones de laboratorio. En este sentido,

\footnotetext{
${ }^{76}$ La traducción del título es "Pueden morderme los ratones si no es verdad", y está tomado de un cuento popular germánico del libro Leyendas del Rin delautor Wilh Ruland.
} 
los ratones Franz, Felix, Joseph y Gilles son la manifestación real de la fusión entre arte y ciencia, entre ser humano y animal, entre persona y personaje.

\section{Multiplicidad}

Edenia de Proyecto Untitled es una instalación interactiva que representa un jardín futurista. La obra se despliega en una sala oscura repleta de cables que se enroscan en el piso y ascienden como raíces formando troncos. En cada uno de estos tecnotroncos se observa una planta iluminada puntualmente por una fuente externa que bien podría ser un sol sintético. Las plantas que pueblan Edenia son híbridos formados de partes orgánicas e inorgánicas, organismos compuestos de secciones biológicas y tecnológicas. Entre la variedad de plantas se encuentran unas orquídeas transgénicas provenientes de los laboratorios de la Universidad Maimónides que conviven con Floris lupus, una flor mecánica que interactúa con los espectadores abriendo y cerrando sus pétalos dependiendo de la proximidad de los mismos [figura 35].

En consecuencia, el jardín de Edenia representa la multiplicidad, la simultaneidad y la mixtura que se observa en la cultura contemporánea. Es un collage medioambiental en donde conviven todas las especies: naturales y artificiales.

Unicidad

Edunia es el resultado del cruce entre una planta y un ser humano, una nueva forma "plantanimal"77 que Eduardo Kac creó para la obra Natural Historia of the Enigma. Se trata de una petunia modificada genéticamente para expresar el ADN del artista en sus nervaduras. El gen humano utilizado proviene de la sangre del artista y produce una

\footnotetext{
${ }^{77}$ Kac, E. (2009) "Natural History of the Enigma”. Disponible en http://www.ekac.org/nat.hist.enig.html.
} 
proteína que posibilita su desarrollo únicamente en las nervaduras de la planta que presenta un color rojizo [figuras 36 y 37 ].

Este ser creado por la biotecnología no existía con anterioridad en la naturaleza, es único, y es una nueva expresión del cruce entre la ciencia y el arte contemporáneo que evoca la mezcla, el diálogo y la unión entre las diferentes especies de seres que habitan el ecosistema.

En síntesis, lo que hasta aquí se analizó es la tensión que produce el bioarte, en tanto práctica artística contemporánea, respecto del carácter material, local, continuo y permanente de la obra moderna. La obra de bioarte, además de cambiar y mutar invariablemente, es una obra híbrida que manifiesta las complejidades que este concepto representa.

Los dispositivos en que se presenta generalmente la obra de bioarte, como la instalación o las variantes de prácticas performativas, no son fijos ni permanentes, a menudo establecen horarios, fijan citas y proponen lugares de encuentro para acceder a las obras. De este modo se constituye su no-disponibilidad frente a la disponibilidad permanente de la obra moderna. Por otra parte, por sus características orgánicas, la obra de bioarte presenta una inestabilidad formal debido a sus condiciones biológicas. Como cualquier ser orgánico, las obras de bioarte poseen una duración que dependerá fundamentalmente del tiempo de vida que varía según: el organismo que se utilice, las condiciones ambientales y el cuidado del mismo.

El carácter inestable de las obras se convierte en un tema conflictivo cuando ingresa al museo, un ámbito tradicional creado para coleccionar, conservar y exhibir obras fijas, continuas y permanentes. La obra Victimless Leather exhibida en el Museo de Arte Moderno de Nueva York desbordó al personal del museo que no pudo contener ni 
manejar a la producción de bioarte. Las autoridades tomaron la decisión de sacrificarla al desconectar el suministro de alimentación dando por concluida la duración -y con ello- la obra misma.

Otra característica que presenta la obra de bioarte, es la manifestación de los distintos modos en que se revela el concepto de hibridación en la contemporaneidad. El híbrido designa un estado de cruces, mezclas e intercambios entre los distintos elementos que lo componen. De este modo, las obras híbridas de bioarte pueden apelar a un aspecto conciliatorio de integración, o por el contrario plantear un estado de crisis conflictivo. Las propiedades que constituyen las obras, y que provienen de mundos diferentes, algunas veces son visibles por estar yuxtapuestas, y en otros casos invisibles por estar fusionadas. En consecuencia, las obras pueden evidenciar la variedad, la heterogeneidad y la multiplicidad de elementos que conviven, o contrariamente, volverlos homogéneos en un único y nuevo elemento disponible.

Todas estas propiedades de la obra de bioarte que exhiben la inestabilidad, el dinamismo, el cambio y la mixtura, son también rasgos propios de la producción artística contemporánea. 
4. FIGURAS DE ARTISTA 


\subsection{La crisis de la noción de autor}

Puede decirse que el concepto de creación artística así como el papel del artista sufren transformaciones decisivas desde el renacimiento y particularmente con las transformaciones sociales, culturales y políticas que están ligadas al desarrollo del capitalismo. En ese contexto, puede vinculárselos con el desplazamiento que se produce en el campo de la filosofía hacia el sujeto como punto de partida de la reflexión, que también se liga al surgimiento mismo de la modernidad. Con el propósito de dar fundamento a la incipiente ciencia físico matemática, la filosofía moderna postula al yo como fundamento, a la vez que lo considera como una realidad completamente diferente de la naturaleza, es decir, irreductible a leyes cósmicas. Esto puede verse claramente en la obra de Descartes, considerado el primer filósofo moderno, quien distingue la conciencia como substancia pensante, plano de la voluntad libre, de la naturaleza considerada como substancia extensa y que funciona mecánicamente. De esta manera el orden humano comienza a obedecer a principios subjetivos que ya no dependen de Dios o de la naturaleza. El propio Hegel considera a la subjetividad como el principio de la modernidad. Desde su punto de vista el camino de la modernidad es un proceso de interiorización. ${ }^{78}$ Hegel entiende la subjetividad fundamentalmente como autoconciencia y libertad. Sobre esta base, el filósofo Charles

\footnotetext{
${ }^{78}$ Cf. Habermas, J. (2008). El discurso filosófico de la modernidad. Buenos Aires: Katz.
} 
Taylor sostiene que la modernidad es un proceso de interiorización de las fuentes de las reglas éticas, morales y políticas. ${ }^{79}$

En el campo del arte, Jean Galard ubica en el Renacimiento la primera aproximación a la idea de arte concebido como expresión de una subjetividad, cuando Ficino opone el privilegio del tema tratado a la nueva importancia de la forma personal, de la manera del artista "...la revelación del espíritu a sí mismo es el fin más elevado a que se puede tender, la idea de que el artista expresa su subjetividad se asocia inmediatamente a la creencia según la cual la actividad artística contiene en sí misma su propia finalidad."80 Este proceso hacia la autonomía del arte llevó más de dos siglos y coincidió con el fin de los encargos. De este modo se libera al arte del servicio de cualquier otra cosa que no sea él mismo y los artistas pueden sentirse libres de crear obras con toda independencia en el más absoluto aislamiento, si bien aparece el mercado como una nueva instancia de legitimación. ${ }^{81}$

En el plano de la teoría estética en general las concepciones modernas también hacen un giro hacia el sujeto y se centran en el estudio de lo que se denominará la experiencia estética y la fundamentación del "juicio de gusto". Posiblemente la expresión más acabada de ello se encuentre en la estética kantiana. Kant intenta, al examinar las características del juicio de gusto, conciliar lo subjetivo con la aspiración a la universalidad. Asimismo tiene un papel central la idea de genio, con la que no sólo trata el problema de la creación sino que explica el modo cómo se da el funcionamiento del campo artístico, que es autónomo respecto de cualquier otro.

(con) la noción de genio Kant trata el problema de la creación artística y, puesto que mediante el genio la naturaleza da la regla al arte, también el vínculo entre arte y naturaleza. Más aún, liga dos términos que parecen en principio irreconciliables: la regla y lo individual, lo universal y lo singular. La creación

\footnotetext{
${ }^{79}$ Cf. Taylor, C. (1989/2006). Fuentes del yo. Barcelona: Paidós.

${ }^{80}$ Galard, J. (1971/1973). Muerte de las bellas artes. Madrid: Fundamentos, p. 27.

${ }^{81}$ Ibidem., pp. 28-29.
} 
consiste en la producción de una obra original de un modo, podría decirse, infundado, que no encuentra precedentes en otros artistas, por lo que genera una ruptura dentro del arte e impone nuevos criterios. ${ }^{82}$

Ahora bien, desde fines del siglo XIX y sobre todo a partir del siglo XX los enfoques modernos y la preeminencia de una noción fuerte de sujeto -ese sujeto cartesiano que se pone en contacto con su interioridad, que pretende el autocontrol y el de la naturaleza- ha sido objeto de indagación filosófica y de las ciencias sociales. En el siglo XIX los "autores de la sospecha" como denominó Paul Ricoeur ${ }^{83}$ a Marx, Freud y Nietzsche, cuestionan desde perspectivas completamente diferentes la supuesta autonomía y transparencia del sujeto moderno.

Posiblemente sea la de Heidegger la crítica más profunda a la preeminencia moderna del sujeto ${ }^{84}$. Para este autor el interrogante por el ser constituye la principal tarea de la filosofía. ${ }^{85}$ Se trata de la pregunta ontológica originaria, que la metafísica occidental ha olvidado y sustituido por una interrogación por el ente. De tal modo para Heidegger la filosofía occidental es el resultado de un progresivo olvido de la pregunta por el ser, olvido que alcanza su mayor profundidad en la modernidad, con lo que denomina metafísica de la subjetividad. Si bien, según Heidegger, la tendencia hacia la subjetividad se encuentra ya en la filosofía platónica, es a partir de Descartes que logra su pleno florecimiento. En el giro moderno hacia la subjetividad el ser del ente consiste en ser "objeto", esto es, de enfrentarse con el sujeto que lo pone ante sí como objeto de conocimiento. Por eso Heidegger caracteriza a la modernidad como la época de la imagen del mundo ${ }^{86}$, el mundo deviene una representación para un sujeto.

\footnotetext{
82 Melamed, A. (noviembre de 2010). "La angustia entre creación e imitación: perspectivas contemporáneas sobre la teoría del genio". Revista figuraciones. Teoría y crítica de las artes, (7). Buenos Aires: Instituto Universitario Nacional del Arte.

${ }^{83}$ Ricoeur, P. (1965/1970). Freud: una interpretación de la cultura. México: Siglo XXI.

${ }^{84}$ Resulta sumamente complejo y ha sido largamente discutido el vínculo de esta crítica de Heidegger a la modernidad y su adhesión al nazismo.

${ }^{85}$ Cf. Heidegger, M. (1935/2001). Introducción a la metafísica. Barcelona: Gedisa.

${ }^{86}$ Cf. Heidegger, M. (1938/2000). Op. cit.
} 
Vinculado al surgimiento de la ciencia, la modernidad distorsiona la estructura originaria e inescindible hombre-mundo poniendo en su lugar la relación sujeto-objeto, es decir, una relación de conocimiento y de dominio. De allí que la modernidad sea para Heidegger la época del despliegue de la técnica. Y por técnica entiende no su representación instrumental sino un modo fundamental del moderno ser en el mundo. La técnica es un modo de pensar que consiste en calcular, medir, clasificar; es una actitud hacia la naturaleza, es decir, un estado de desocultamiento de la naturaleza según la cual ésta se ve reducida materia explotable, una fuente de energía que debe ser extraída y almacenada. La técnica moderna resulta un sistema, un conjunto de dispositivos, ajustes, engranajes, de dominación y explotación total. En este marco, la metafísica moderna de la subjetividad se convierte en un humanismo que enmascara la deshumanización. ${ }^{87}$

En el horizonte de la crítica de Heidegger, también cuestionan la noción de sujeto, los estructuralistas del siglo $X X$ como Saussure y Jakobson, y los llamados posestructuralistas como Foucault, Kristeva y Barthes. En líneas generales, para estos autores no es posible considerar un sujeto autónomo, o un sujeto que se construye a sí mismo, en todo caso la subjetividad sería efecto de una estructura, una trama que lo precede, de orden discursivo. Por lo tanto, los estudios estructuralistas y postestructuralistas no se centran en el sujeto sino en aquello que crea esas formas de subjetividad y ello conlleva a declarar, en ciertos casos, la muerte del sujeto.

En este sentido, Barthes sostiene que con la muerte del sujeto moderno también se da muerte al autor. ${ }^{88}$ Esta noción es una clara crítica a la concepción romántica que ubica al autor en un lugar central por sobre la obra, concibiendo entonces al creador como

\footnotetext{
${ }^{87}$ Cf. Melamed A., (agosto de 2014). "La pregunta por la técnica en el arte". IV Coloquio Internacional de Filosofía del Conocimiento, Facultad de Humanidades y Ciencias de la Educación, UNLP. La Plata, Argentina.

${ }^{88}$ Barthes, R. Op. cit., p. 68.
} 
genio divino que da forma a la inspiración mediante la configuración de una obra artística, y donde el espectador (en el caso de Barthes sería el lector) cumple la función de interpretar, o intentar entender, aquello que el autor quiso comunicar. Para Barthes el autor no es nada original, se limita a mezclar escrituras siempre anteriores, a explicar las palabras a través de otras palabras, su obra es un entretejido de citas, repeticiones y referencias a varias culturas cuyo resultado es la disolución del autor para pasar a ser simplemente lenguaje, una localización donde los intertextos se cruzan continuamente.

Por su parte, Foucault en el texto “¿Qué es un autor?" de 1969 distingue entre la persona real y el autor. La figura de autor tendría fundamentalmente una función clasificatoria, que permite clasificar, agrupar y distinguir textos.

En la escritura, no se trata de la manifestación o de la exaltación del gesto de escribir; no se trata de la sujeción de un sujeto a un lenguaje: se trata de la apertura de un espacio en donde el sujeto que escribe no deja de desaparecer [y agrega más adelante] esta relación de la escritura con la muerte se manifiesta también en la desaparición de los caracteres individuales del sujeto escritor; mediante todos los ardides que establece entre él y lo que escribe, el sujeto escritor desvía todos los signos de su individualidad particular; la marca del escritor ya no es más que la singularidad de su ausencia; tiene que representar el papel del muerto en el juego de la escritura. Todo esto es conocido; y hace mucho tiempo que la crítica y la Filosofía tomaron nota de esta desaparición o de esta muerte del autor. ${ }^{89}$

La discusión sobre la muerte del autor es amplia y ha sido estudiada por numerosos teóricos alrededor del mundo. En el ámbito local también se ha tratado la cuestión de la crisis o muerte del autor en diversos campos. Resultan de interés para nuestra investigación los trabajos de Daniela Koldobsky y María Noel Correbo que vinculan la

\footnotetext{
${ }^{89}$ Foucault, M. Op. cit.
} 
muerte del autor con el surgimiento de nuevas "figuras" o "roles" que encarna el artista contemporáneo.

En el caso de Koldobsky, considera que a esta muerte del autor le acompañan otras muertes producidas en el seno de las artes visuales tradicionales como la muerte de la pintura, la muerte del plano y hasta la muerte misma del arte:

La muerte del autor literario decretada por Barthes en su texto de 1968 convive en un espacio intertextual contemporáneo de anuncio de diversas muertes: del lenguaje pictórico, de ciertos elementos de ese lenguaje como el plano e incluso del arte en general, que en relación con las artes visuales se había comenzado a gestar ya desde el momento en que los dadaístas hablaban del anti-arte $\mathrm{y}$, fundamentalmente, exponían un objeto que no podía circunscribirse al concepto de obra, es decir, a la concreción de un objeto único creado por la mano del artista y consecuentemente portador de un aura. Son los objetos y las experiencias que tienen entre sus condiciones de producción al ready made de Duchamp, los que escenifican ese proceso de borramiento de una figura a la que se le decreta la muerte. ${ }^{90}$

En este movimiento cae la noción de obra y con ella la noción de artista vinculada principalmente al romanticismo que lo concibe como genio inspirado por las musas, creador de producciones únicas y singulares que deja en cada obra su impronta, su marca, su huella física.

En tanto que Correbo señala que las modificaciones operadas por las neovanguardias a mediados de siglo $\mathrm{XX}$ redefinieron en el sistema artístico, entre otras cosas, la figura de autor "tensionando su lugar y cuestionando su estatuto en la constante exploración de nuevos roles." ${ }^{91}$ De este modo, la figura de autor varía en la contemporaneidad dependiendo de la función que cumpla en la obra.

\footnotetext{
${ }^{90}$ Koldobsky, D. Op. cit.

${ }^{91}$ Correbo, M. N. "Algunas consideraciones sobre la figura del artista-científico". En Suárez Guerrini, F.; Gustavino, B.; Correbo, M. N. y Matewecki, N. Usos de la ciencia en el arte argentino contemporáneo. Buenos Aires: Papers, p.88.
} 


\subsection{Las figuras de artista en el bioarte}

Las distintas figuras de artista que ingresan al arte contemporáneo son consecuencia principalmente de la influencia del dadaísmo y del abandono de dispositivos y soportes tradicionales como la pintura y la escultura.

En el caso del bioarte, la estrecha relación que mantienen los artistas con los métodos y procedimientos de las ciencias biotecnológicas provoca variaciones y desplazamientos en la figura del autor. La determinación de cada uno de estos roles depende de la producción textual que refiere a los distintos autores y sus obras tales como críticas, reseñas, entrevistas, biografías, manifiestos, ponencias, etc. Del análisis de estos textos se desprenden distintas figuras de artista que proponemos caracterizar como artista-científico, artista-investigador y artista-divulgador.

\subsubsection{Artista-científico}

Las obras de bioarte se desarrollan, en su mayoría, en laboratorios de biotecnología dependientes de universidades o compañías. Los científicos siguen rigurosos protocolos técnicos para practicar el cultivo de tejidos y la manipulación de genes que van desde el comportamiento dentro del laboratorio respetando las normas de higiene, limpieza personal, limpieza de materiales, utilización de batas, guantes descartables y la precaución de no ingresar elementos del exterior que puedan provocar la contaminación de los cultivos; hasta la cantidad de nutrientes, tiempo de centrifugación y tiempo de incubación que requiere un cultivo.

Los artistas que deciden producir su trabajo bajo esta serie de normas y condiciones se los denomina artistas-científicos. Si bien muchos bioartistas pasan en algún momento por la experiencia del trabajo de laboratorio, los casos seleccionados 
demuestran que su implicancia en esta tarea es mucho más comprometida, trabajando a la par que un científico titulado e involucrándose no sólo con el aspecto técnicometodológico sino también con la investigación y la innovación científica.

Joe Davis fue uno de los primeros artistas en investigar y realizar tareas del laboratorio que incluían manipulación de ADN para desarrollar sus propuestas artísticas. En 1973 se graduó en Bellas Artes en el Mount Angel College de Oregon, en los Estados Unidos. En 1982 ingresó en el Center for Advanced Visual Studies ${ }^{92}$ del prestigioso MIT para enseñar a estudiantes de grado y posgrado diversas técnicas mixtas. Luego, en 1986 comenzó a contactarse con ingenieros y científicos de otros departamentos del MIT para empezar a producir sus obras artísticas interdisciplinarias. Finalmente, en 1990 fue nombrado Investigador Afiliado para trabajar en el Laboratorio de Bioquímica, Biofísica y Estructura Molecular del Doctor Alexander Rich, en el departamento de Biología del MIT, donde ha realizado una amplia labor de investigación en biología molecular y bioinformática para la producción de bases de datos genéticos y nuevas formas de arte biológico [figura 38].

El interés de su producción artístico-biológica se centra, sobre todo, en generar mensajes e imágenes de gran importancia que puedan ser decodificadas por futuras generaciones o por culturas extraterrestres. En este sentido, en 1986 crea Microvenus, una obra que surge de la traducción a lenguaje binario y luego a código genético de un signo germano antiguo que representa la vida y la Tierra femenina. La imagen fue convertida en una secuencia de nucleótidos con el fin de formar una molécula sintética de ADN para ser utilizada por primera vez en el campo del arte [figura 39].

\footnotetext{
92 ElCenter for Advanced Visual Studies (Centro de Estudios Visuales Avanzados) es un programa del MIT para el apoyo de nuevas producciones artísticas que se encuentren en la intersección entre arte y ciencia. A través de un laboratorio interdisciplinar, científicos, artistas, investigadores, alumnos y residentes intercambian ideas, opiniones e información para facilitar la práctica artística que se ubica en los bordes disciplinares. Este Centro fue fundado en 1967 por Gyorgy Kepes, conocido por defender la relación entre arte y tecnología y por su amistad con miembros de la Bauhaus como Laszlo Moholy-Nagy.
} 
La secuencia fue inicialmente sintetizada por Davis en la Escuela de Medicina de Harvard junto al científico Martin Bottfield. Luego, los oligonucleótidos sintéticos resultantes se purificaron en la Universidad de California con Dana Boyd (bióloga molecular y genetista que colaboró con el artista en una obra anterior llamada Poetica Vaginal), para finalmente introducir mediante transgénesis ${ }^{93}$ la secuencia genética dentro de bacterias E. coli. Esta tarea también fue llevada a cabo por Davis en colaboración con el personal del laboratorio de Alexander Rich en el departamento de Biología del MIT.

La idea de Davis para esta obra, era difundir las bacterias de Microvenus por el espacio para que las inteligencias extraterrestres las encuentren y puedan decodificar los mensajes que portaban en su interior. Sin embargo, este anhelo nunca fue llevado a cabo.

En 1994 creó Riddle of Life (Enigma de la vida), su segunda obra genética que fue exhibida por primera vez en el Festival Ars Electronica de Linz, Austria, en el año 2000. El proyecto comenzó cuando Davis se enteró de la rivalidad que existía, en la historia de la genética, entre el físico Max Delbrück y el biólogo George W. Beadle: "eso fue antes de que trabajaran en el código que unía 20 tripletes diferentes de nucleótidos de ADN a los 20 aminoácidos (...). Ellos ni siquiera sabían si había 'espacios' que separasen cada triplete," ${ }^{94}$ comentaba Davis en una entrevista. Delbrück creía que el ADN contenía espacios entre sus "palabras" y Beadle estaba en desacuerdo con esa teoría.

\footnotetext{
${ }^{93}$ Se utilizó la técnica de ligadura de una sola hebra, de extremo romo con pUC19 y vectores del plásmido pSK-M13+. Davis, J. (2004). "Monsters, maps, signals and codes". En D. Bulatov, D. (Ed.), BioMediale. Contemporary Society and Genome Culture. Russia: The National Center for Contemporary Arts/The National Publishing House, p. 344.

${ }^{94}$ La traducción es mía "This was back before they had worked out the code that matches 20 distinct triplets of DNA nucleotides to the 20 amino acids (...). They didn't even know whether there were "spaces" that separated each triplet." Gibbs, W. (2001, 17 de abril). Entrevista a Joe Davis: "Art as a form of life". Scientific American Magazine.http://www.scientificamerican.com/article.cfm?id=art-as-a-form-of-life.
} 
En 1958 Beadle fue galardonado con el Premio Nobel, como también Joshua Lederberg. Cuando Delbrück y sus compañeros de trabajo se enteraron de la noticia, le enviaron un telegrama codificado con una cadena de 229 bases de ADN. Al recibirlo, Beadle dedujo rápidamente que las cuatro letras simbolizaban las cuatro bases del ADN, así rompió el telegrama en tríos (o tripletes) y decodificó el mensaje que decía: "ROMPER ESTE CÓDIGO O DEVOLVER EL PREMIO NOBEL LEDERBERG VETE A CASA MAX MARKO STERLING." ${ }^{95}$ Al día siguiente, Beadle le envió a Delbrück un telegrama escrito en un código de cuatro letras, pero diferente, ya que carecía de espacios entre caracteres. Delbrück resolvió rápidamente el acertijo que decía "GWBTOMDIMSUREITSAFINEMESSAGEIFICOULDDOTHEFINALSTEP"96, sin embargo no lo dejaría quedarse con la última palabra. Cuando Beadle estaba recibiendo el Premio Nobel de manos del Rey de Suecia, un mensajero entró al reciento y le entregó una serie de palillos pintados con cuatro colores para que decodificase el mensaje en el lugar, entonces Beadle lo decodificó y leyó: "YO SOY EL ENIGMA DE LA VIDA, CONÓCEME Y TE CONOCERÁS A TI MISMO". ${ }^{97}$ Insipirado por esta historia, Davis realizó una secuencia genética artificial que representaba la cita leída por Beadle en la entrega de los Nobel. La secuencia fue transferida a bacterias E. coli que permanecen guardadas en el laboratorio del MIT. Para la exhibición de Riddley of life en Ars Electronica, no se enviaron los organismos transgénicos desde Estados Unidos sino que todo se desarrolló íntegramente, y desde el principio, en laboratorios de Europa.

\footnotetext{
${ }^{95}$ La traducción es mía: "BREAK THIS CODE OR GIVE BACK THE NOBEL PRIZE LEDERBERG GO HOME MAX MARKO STERLING". Ibidem.

${ }_{96}^{6}$ G. W. B. (George W. Beadle) a M. D. (Max Delbrück) estoy seguro que el mensaje está bien si pudiera dar el paso final.

${ }^{97}$ La traducción es mía: "I AM THE RIDDLE OF LIFE KNOW ME AND YOU WILL KNOW YOURSELF". Ibidem.
} 
Hacia el año 2000, Davis realizó una nueva obra llamada Milky Way DNA basándose en los dibujos de un amigo. Las imágenes describían la historia de un niño que no iba a hallar la felicidad hasta que encontrara un ratón que tuviera el mapa del mundo entero en su oreja. A partir de este relato, el artista comenzó a trabajar en la traducción de una imagen de la vía láctea a código genético. Consiguió una fotografía en alta definición tomada por el satélite COBE de la NASA que pasó primero a código binario, luego a código hexadecimal y finalmente a código genético. La gran definición que tenía la fotografía permitió generar una molécula de ADN de 3867 bases, la molécula sintética más grande realizada hasta entonces. Una vez conseguido esto, solo restaba transferirla al genoma de un ratón para que el mapa del mundo entero viviera en su oreja.

La síntesis de ADN generada para Milky Way DNA fue exhibida por primera vez en el 2002, en la muestra "Biología Como Arte" en Barcarena, Portugal.

Una de las últimas ideas de Joe Davis fue premiada con el Golden Nica ${ }^{98}$ en la categoría "Arte híbrido" del Festival Ars Electronica del 2012. Se trata del proyecto de una obra en proceso que consiste en una radio bacteriana o bioradio. Los circuitos eléctricos que integran esta radio son orgánicos, y se forman a partir de bacterias modificadas con genes que les confieren cualidades eléctricas. Las bacterias son clonadas con un gen específico que proviene de las esponjas marinas Tethya aurantia, y que permite remover circuitos electrónicos. Las bacterias son introducidas en los circuitos de la placa de la radio logrando así la transmisión de sonido.

La radio bacteriana representa la síntesis entre el desarrollo científico y la creación artística. Esto resulta así, porque para Davis las dos esferas son imposibles de separar

\footnotetext{
${ }^{98}$ Se denomina Golden Nica al premio mayor que otorga el festival Ars Electronica. Consiste en un trofeo de una Victoria de Samotracia enchapada en oro y dinero en efectivo.
} 
pues él habla ambos idiomas. ${ }^{99} \mathrm{Y}$ eso se observa, por ejemplo, en el campo del arte donde sus ideas abrieron camino para la producción estética de un arte viviente modificado genéticamente, como también en el campo de la ciencia, donde revolucionó con sus experimentos y desarrollos de genes sintéticos de gran cantidad de bases, que hasta pudieron terminar con la creación de un supervirus. ${ }^{100}$

Otro caso que representa la figura de artista-científico es el de Marta de Menezes [figura 40]. La artista portuguesa viajó a fines de los noventa hasta la Universidad de Leiden en Holanda con motivo de aprender una técnica denominada microcauterización que le permita modificar el diseño de las alas de las mariposas. La idea de este proyecto partió de un artículo que leyó sobre unos científicos que habían modificado los dibujos de las alas de unas mariposas para explorar cuestiones biológicas. La artista entró en contacto con el investigador principal Paul M. Brakefield de la Universidad de Leiden para tomar una residencia y pasar un tiempo en su laboratorio trabajando junto a los científicos. Así creó Nature? (¿Naturaleza?), utilizando una aguja fina unida a un generador de calor que le permitió modificar el diseño de una de las dos alas cuando las mariposas aún estaban creciendo dentro de su capullo [figuras 41 y 42 ]. Este procedimiento no perturbaba el desarrollo ni la vida normal de las mariposas, tan solo las modificaba visualmente [figura 43]. Las mariposas manipuladas fueron exhibidas vivas en Ars Electronica en el año 2000.

Ese mismo año la artista realizó otra residencia, esta vez en el laboratorio de la Dra. Ana Pombo en el Imperial College de Londres, Inglaterra, donde desarrolló NucleArt (NucleArte). Una serie de obras donde utilizaba moléculas de ADN acopladas a tintes

\footnotetext{
${ }^{99}$ Ferdinand, P. (2001, diciembre). "Art and Science: at MIT, Science Gives New Life to Art". Washington Post.

${ }^{100}$ En una entrevista, Davis comenta que a veces no se da cuenta de lo peligrosas que pueden llegar a ser sus ideas. Un día hablando con un científico genetista le comentó que quería hacer una secuencia de 200aminoácidos para introducirlos plegados en una cápsula altamente geométrica. El genetista le respondió que afortunadamente no lo hizo porque inadvertidamente estaba creando un supervirus. Gibbs, W., Op. cit.
} 
biológicos fluorescentes para pintar tanto cromosomas como genes ubicados en los núcleos de las células humanas [figura 44]. Con ayuda de un microscopio confocal laser, las imágenes de las células con sus núcleos pintados se reconstruyeron digitalmente en tres dimensiones conformando una suerte de "micro-esculturas" vivas que fueron filmadas y proyectadas en pantallas curvas translúcidas [figura 45].

Más tarde, con la idea de llevar adelante la creación de esculturas biológicas tridimensionales de manera real, asistió durante seis meses a una residencia en el laboratorio SymbioticA de la Universidad de Western Australia, donde aprendió junto al equipo del Dr. Giles Plant, las técnicas de cultivo tisular con el fin de aplicar este conocimiento al crecimiento de neuronas vivas sobre estructuras en tres dimensiones. Así creó Tree of Knowledge (Árbol del Conocimiento), una escultura con forma de árbol que construye mediante dos técnicas: por un lado utiliza una matriz donde aplica el cultivo neuronal que crece y degrada dicha matriz [figura 46], y por otro lado, rellena unos pequeños tubos de vidrio con las células neuronales [figura 47]. Las conexiones entre las neuronas que se multiplicaban fueron dando forma al árbol. La propia vitalidad de las células hizo que el árbol creciera, cambiara, estableciera nuevas conexiones y eliminara otras viejas.

El proyecto que está desarrollando de Menezes desde 2012 se denomina Leda e incluye varios aspectos mostrados en obras anteriores como la elección de mariposas, la noción de retrato, y por supuesto, el uso de cultivos celulares. Partiendo de un tipo específico de mariposa conocido como Leda Melanitis, esta mariposa nocturna de color marrón será intervenida para mezclarse con los genes de la artista griega Yiannis Melanitis. A través de la técnica de microinyección (frecuentemente utilizada en transgénesis), los genes humanos serán insertados al genoma del insecto que compartirá con la artista griega algo más que su apellido. 
Para Marta de Menezes su obra explora las posibilidades que la biotecnología como nuevo medio artístico le ofrece a los artistas. Su discurso artístico no es posible de llevar adelante con un medio que no sea ADN, proteínas y células. Los laboratorios de investigación biológicos son para de Menezes su atelier artístico, las metodologías y protocolos científicos que sigue en cada una de sus obras se convierten en las técnicas adecuadas para explorar nuevas formas de representación y comunicación. ${ }^{101}$

Otra artista que pasó varios meses alojada en los laboratorios de la UWA para realizar sus obras es Tagny Duff. Durante la primera residencia de doce meses de duración produjo Living Viral Tattos (Tatuajes Virales Vivos). Dos años más tarde realizó una segunda residencia de cinco meses para desarrollar Cryobooks archives (Archivos de criolibros), una obra que retoma los conocimientos científicos aplicados en la primera residencia. El uso de células huésped infectadas con virus y de protocolos para inmunohistotinción aplicados en Living Viral Tattoos fueron utilizados nuevamente para imprimir las páginas de los libros criogenizados realizados con piel humana y animal. Cryobooks archives es una instalación, una biblioteca portátil compuesta por libros cuyas tapas son de tejido viral humano-animal congelado. La obra reflexiona sobre la historia de las prácticas quirúrgicas tempranas en Europa que buscaban extender y preservar la vida útil de los tejidos humanos a través de la práctica de la bibliopegía antropodérmica, una técnica de encuadernación hecha con piel de cadáveres humanos.

Tradicionalmente los libros plantean ideas, transmiten información y documentan el conocimiento humano a través de la piel de los árboles y animales que dan forma a las páginas de papel y a las cubiertas de cuero. Basándose en esta noción, Duff decide

\footnotetext{
${ }^{101}$ Extraído del sitio oficial de la artista http://martademenezes.com
} 
hacer sus libros también con piel pero trabajada a nivel discreto mediante técnicas de biotecnología. Durante su segunda residencia en el laboratorio, Duff crea libros artístico-biológicos a través del uso de piel humana, piel de cerdo, suturas quirúrgicas, manchas inmunohistoquímicas y lentivirus biológico (un derivado no patógeno de la cepa HIV-1).

El protocolo utilizado para el proceso de tinción inmunohistoquímico fue desarrollado para Living Viral Tattoos por el Dr. Stuart Hodgetts quien colaboró en su adaptación para esta nueva obra. Acerca de los protocolos científicos, la artista señala que son una especie de receta o partitura que debe seguir para aprender una técnica específica; sin embargo, en tanto medio artístico, puede desviarlo ligeramente, alterarlo o modificarlo con un propósito crítico y reflexivo [figura 48]. ${ }^{102}$

Para la realización de esta obra, Duff debió seguir varios pasos dentro y fuera del laboratorio. En primer lugar debió realizar las gestiones necesarias para conseguir tanto la piel humana como la piel animal. Para utilizar la piel animal (en este caso cerdo) el procedimiento no revistió mayor complejidad pues es posible adquirirla en cualquier carnicería. En cambio, para utilizar la piel humana tuvo que contactarse con pacientes que se sometieran a una cirugía plástica y pedirles su consentimiento con el fin de utilizar los residuos de piel post-quirúrgica [figura 49]. Asimismo debió presentarle al cirujano plástico todos los avales de bioética y bioseguridad proporcionados por el laboratorio SymbioticA y por la Universidad de Western Australia para llevarse los restos de piel.

En segundo lugar tuvo que aprender las técnicas de sutura quirúrgica para unir las páginas de los libros, por cuanto tomó un curso y practicó con distintos tipos de agujas

\footnotetext{
${ }^{102}$ Extraído del sitio creado por la artista para esta obra http://cryobookarchives.wordpress.com
} 
e hilos biodegradables sintéticos y no sintéticos para hallar la unión más adecuada [figura 50].

Luego vendría todo el procedimiento de laboratorio que consistió en reproducir la línea celular HaCat a la que se le transfirió el lentivirus [figura 51]. Este cultivo fue posteriormente transplantado a la piel humana y de cerdo donde hizo su manifestación visible en el lugar donde la artista estampó un sello, allí la coloración de la piel cambió a un tono blancuzco [figuras 52 y 53 ]. ${ }^{103}$

Finalmente debía idear, diseñar y construir un gabinete criorefrigerado que preserve y exhiba la colección de libros. El proceso de la obra fue presentado en varios eventos y establecimientos artísticos a través de charlas, fotos y videos. No obstante, la primera vez que pudo exhibir la obra en vivo -y viva- fue en una galería científica, pues anteriormente no se lo habían permitido hacerlo en una galería artística. En una entrevista la artista comentó al respecto [ver ]:

(...) Exhibirla aquí en una galería científica es una experiencia maravillosa. Es muy alentador para la gente que está familiarizada con la ciencia y el arte. En realidad es muy poco común encontrar gente que esté trabajando con arte y ciencia, he tenido muchos desafíos en mi vida. Esta es la primera vez que el trabajo se exhibe, porque cuando intenté mostrarla anteriormente en un contexto artístico me encontré con una gran preocupación por parte del público y de los administradores. De hecho, la obra fue censurada hace un par de años porque la galería estaba muy preocupada con el tema de la salud y la seguridad; y, por supuesto, como ustedes pueden ver aquí la obra está sellada y contenida herméticamente. Yo creo que en realidad la tos siempre ha sido mucho más peligrosa que esta obra. ${ }^{104}$

\footnotetext{
${ }^{103}$ La idea original era que la mancha tome un color azulado, como en Living Viral Tattoos, pero un error de proporción en la mezcla química de la solución $4 \mathrm{CN}$ provocó que las manchas quedaran de color blanco.

${ }^{104}$ Extraído de la videoentrevista realizada por la galería en donde fue expuesta la obra. Science Gallery Dublin. (2011). "Tagny Duff. Cryobooks Archives". Disponible en https://www.youtube.com/watch?v=Bdnb4U7eP k
} 
Por otra parte la versión final del protocolo desarrollado para esta obra fue escrito en un documento técnico (comúnmente denominado paper) en coautoría con los científicos Jill Muhling; Maria Grade Godinho y Stuart Hodgetts, con el fin de ser publicado para darle difusión al experimento. Esto demuestra la estrecha relación que Tagny Duff mantiene con el ámbito de la ciencia por cuanto es posible caracterizarla como un artista-científico que combina en igual medida saberes del arte y saberes de la ciencia.

No se puede dejar de mencionar en este apartado a los artistas lonat Zurr y Oron Catts, directores y fundadores del laboratorio SymbioticA, el centro de artes biológicas más importante por donde pasaron la mayoría de los artistas-científicos para realizar sus residencias de investigación y producción.

En 1996 Catts y Zurr se vincularon con científicos del instituto oftalmológico de Perth, Lions Eye Institute, para desarrollar imágenes digitales basadas en capturas microscópicas. Allí se contactaron con algunos científicos que trabajaban en la School of Anatomy and Human Biology ${ }^{105}(\mathrm{ANHB})$ de la UWA donde crearon el grupo The Tissue Culture and Art Project. En el 2000 Catts se une a la biologista celular Miranda Grounds y al neurocientífico Stuart Bunt para fundar SymbioticA ${ }^{106}$, un laboratorio artístico dependiente de la UWA dedicado a la investigación y experimentación en ciencias de la vida. La idea principal de este centro fue desarrollar programas que permitieran a los artistas acceder a los laboratorios y a las técnicas normalmente reservadas a los científicos. Los programas incluían residencias, talleres, cursos académicos de grado y posgrado, conferencias, exposiciones, charlas públicas, etc.

\footnotetext{
${ }^{105}$ Se traduce como Escuela de Anatomía y Biología Humana, y se corresponde con lo que en Argentina se conoce como Facultad de Medicina. Actualmente la ANHB incorporó el área de fisiología cambiando su nombre por School of Anatomy, Phisiology and Human Biology (APHB).

${ }^{106}$ SymbioticA: con S mayúscula de science (ciencia) y A mayúscula de art (arte).
} 
En 2008, SymbioticA se convirtió en Centro de Excelencia en Artes Biológicas y en 2010 pasó a formar parte de los Centros de Investigación de la UWA.

El dato curioso es que los pasillos de la ANHB estaban cubiertos de obras del pintor y escultor Hans Arkeveld, quien trabajó durante tres décadas en dicha facultad. Sin embargo, no fue hasta que Catts y Zurr comenzaron a utilizar las herramientas de la investigación científica para producir sus obras que finalmente se pudo concretar un espacio interdisciplinario que relacionara verdaderamente a los artistas con los científicos de la universidad.

Una vez fundado SymbioticA, el TC\&A pasó a desarrollar sus obras en el marco de este laboratorio. A partir del aprendizaje de los métodos de reproducción de líneas celulares y el uso de matrices biodegradables, los artistas generaron una gran cantidad de obras para darle materialidad y forma a sus seres semi-vivos. Estas nuevas clases de vidas surgidas del uso de la tecnología tisular forman parte del pensamiento estético que propone el colectivo artístico para explorar las nociones de vida, identidad, y el lugar del ser humano en relación con los otros seres vivos y el medio ambiente. Las cuestiones éticas y epistemológicas en torno a las ciencias biológicas que rodean a este tipo de vida parcial, también se manifiestan en su producción escrita.

Una de las primeras obras llevadas a cabo en Symbiotica en el año 2000 fue The Semi-Living Worry Dolls (Las muñecas quitapenas semi-vivas) basada en las pequeñas muñecas originarias de Guatemala que miden entre 15 y 50 milímetros, hechas a mano y confeccionadas con madera, alambre y ropa de algodón. El TC\&A realizó unas muñecas similares, fabricadas a mano con un material polimérico degradable (PGA y P4HB) y suturas quirúrgicas. Primero se esterilizaron las muñecas poliméricas y luego se cultivaron con endotelio, músculo y células osteoblastos (piel, 
músculo y tejido óseo) dispuesto sobre los polímeros y entre los polímeros. La matriz se degradó a medida que el tejido crecía y tomó la forma de una muñeca parcialmente viva [figura 54].

Se confeccionaron siete muñecas a las que nombraron con las letras del alfabeto, cada letra correspondía a una preocupación propia de los artistas:

Muñeca $A$ : representa la preocupación de las verdades Absolutas, y de las personas que creen tenerlas.

Muñeca B: representa la preocupación de la Biotecnología, y las fuerzas que la impulsan (ver muñeca $\mathrm{C}$ ).

Muñeca C: equivale al Capitalismo, las Corporaciones.

Muñeca D: equivale a la Demagogia, y a la posible Destrucción.

Muñeca E: equivale a la Eugenesia, y a las personas que piensan que son los suficientemente superiores para practicarla.

Muñeca F: es el miedo al Miedo [Fear] mismo.

Muñeca G: no es una muñeca sino que los Genes están presentes en todas las muñecas semi-vivas.

Muñeca $\mathrm{H}$ : simboliza nuestro miedo a la Esperanza... $\left[\right.$ Hope...]. ${ }^{107}$

Pig Wings Project (Proyecto Alas de Cerdo) fue desarrollado durante una residencia entre los años 2000 y 2001, en el Laboratorio de Ingeniería de Tejidos y Fabricación de Órganos del Hospital General de Massachusetts perteneciente a la Facultad de Medicina de Harvard. Los tres pares de alas fueron realizados con células mesenquimales de cerdo (células madre de médula ósea) cultivadas sobre el mismo polímero biodegradable y bioabsorbible que la obra anterior. El tamaño de las alas era

\footnotetext{
${ }^{107}$ Extraído del sitio web de los artistas. Disponible en http://tcaproject.org/projects/worry-dolls. Doll $A=$ stands for the worry from Absolute truths, and of the people who think they hold them. Doll $B=$ represents the worry of Biotechnology, and the forces that drive it. (see doll C)

Doll $\mathrm{C}=$ stands for Capitalism, Corporations

Doll $\mathrm{D}=$ stands for Demagogy, and possible Destruction

Doll $E$ = stands for Eugenics and the people who think that they are superior enough to practice it.

Doll $F=$ is the fear of Fear itself.

Doll $G=$ is not a doll as the Genes are present in all semi-living dolls.

Doll $\mathrm{H}=$ symbolizes our fear of Hope...
} 
de aproximadamente $4 \mathrm{~cm} \times 2 \mathrm{~cm} \times 0,5 \mathrm{~cm}$, y se cultivaron durante nueve meses dentro de un biorreactor de cultivo celular giratorio.

En esa misma residencia realizaron pequeños filetes a partir del cultivo de células de ovejas prenatales recolectadas dentro del útero, es decir, que el filete de carne que cultivaron era de un animal que aún no había nacido. En el año 2003 exhibieron Disembodied Cuisine (Cocina Incorpórea) una instalación performativa donde desarrollaron filetes de rana semi-vivos partiendo del cultivo de células de músculo esquelético de rana y de la utilización de matrices poliméricas [figura 55]. Con esta obra TC\&A ofrece la posibilidad de crear una carne sin víctimas y de comer un filete sin matar animales, claro que esto es un acto irónico que proponen los artistas pues en más de una oportunidad explicitaron el uso de animales para la experimentación científica. Si bien el filete se formó a partir de células extraídas de una biopsia a un animal vivo que había sido proliferado in Vitro, los métodos para cultivar tejidos requieren del uso de productos derivados de animales para nutrir a las células. Esto parece pasar desapercibido porque los productos de origen animal para el cultivo tisular se presentan en forma "abstracta", en un nivel molecular, pero las víctimas siguen siendo tan reales como si se presentaran en su totalidad. ${ }^{108}$

Disembodied Cuisine pertenece a una serie de obras que se denominó The Victimless Utopia (La Utopía sin Víctimas) donde se encuentra también Victimless Leather (Cuero sin Víctimas), un cultivo tisular que crece degradando una matriz con forma de tapado. Con esta obra se intenta establecer un debate moral acerca del uso de pieles animales y de la explotación de otros seres vivos. Este tipo de planteo ético llevó a producir la obra DIY DVK01, un kit desvictimario que se creó para aliviar parte de la culpa que la

\footnotetext{
${ }^{108}$ En una charla con la bioartista Boo Chapple me comentaba sobre su trabajo que consistía en extraer el colágeno de las colas de los ratones. Me decía que las mujeres cuando se ponen una crema con colágeno no saben realmente de dónde proviene ni cuántos animales matan para ello. Aunque las colas que utilizó la artista provenían del material de descarte que los científicos dejaban, Chapple reconocía que una gran cantidad de ratones habían sido sacrificados para ello.
} 
gente siente cuando consume animales. Ya sea como alimento, por razones estéticas, por una causa accidental o por cualquier otra razón que la persona se sienta culpable de haber matado un animal, este kit puede mantener, y en algunos casos, proliferar y extender la vida de las partes de los cuerpos muertos, al menos hasta que la culpa retroceda [figura 56].

Para poner en uso este kit organizaron una instalación performativa en la que experimentaron junto al público traer de vuelta a la vida partes de animales con ayuda de un laboratorio básico de ingeniería tisular. En este caso la ingeniería pudo revertir los efectos destructivos de la "tecnología humana" al cultivar y nutrir fragmentos de tejido que pertenecían a animales ya fallecidos. La participación activa del público se traducía no solo en el empleo práctico del kit sino también en las decisiones éticas que tomaban respecto del destino final de estos fragmentos de tejido.

Los fragmentos de vida derivados del uso de ingeniería tisular provocaron la reflexión del TC\&A acerca de la crisis taxonómica que presenta la biología contemporánea. Los métodos clásicos de colección, categorización y exhibición que se ven en los museos de Historia Natural están siendo puestos en crisis por la biotecnología que trabaja en torno a la manipulación, mezcla e hibridación generando nuevas clases de seres mixtos. La obra NorArk (NoArca) es un gran contenedor/exhibidor diseñado para mantener y hacer crecer una masa de células y tejidos vivos que se originaron a partir de diferentes organismos. Este recipiente sirve como un cuerpo sustituto para una colección de fragmentos de vida o sub-organismos inclasificables.

Partiendo de los problemas taxonómicos que causan los nuevos fragmentos de vida, deciden crear Odd Neolifism (Neovida Extraña) [figura 57]. Esta obrae xplora los conflictos surgidos en las ciencias biológicas cuando los científicos Van Velen y Maiorana sugirieron que las células HeLa (unas de las más conocidas y utilizadas en 
la investigación científica) podrían constituir una nueva forma de vida o neolife. Eso mismo pensaron Catts y Zurr al encontrar una gran cantidad de rarezas en las líneas celulares que investigaban para producir sus diferentes obras: células que tenían tres organismos diferentes como sus orígenes, células de origen humano y ratón fusionados, células que creían provenir de origen humano y finalmente eran de animal. Estas nuevas formas de vida mixta están empezando lentamente a entrar en las colecciones de los museos catalogadas con números o nombres muy extraños, y forman parte del concepto Neolifism que involucra a los fragmentos de vida cultivados en los laboratorios.

En suma, Joe Davis, Marta de Menezes, Tagny Duff, lonat Zurr y Oron Catts representan el rol de artista-científico por disponer en sus obras -en igual forma y medida- los conocimientos adquiridos en el campo de la investigación científica con los conocimientos adquiridos en el campo de las artes. Por dicha razón, las obras de estos bioartistas se inscriben en esa zona híbrida que genera discusiones, tensiones y ambivalencias provocadas por la dificultad de discernir entre arte y ciencia.

\subsubsection{Artista-investigador}

Los artistas que trabajan en bioarte están involucrados casi indefectiblemente con la labor investigativa, aunque no sean quienes efectúen los experimentos científicos, deben interiorizarse en este campo para saber lo que les puede ofrecer. El artista que indaga, analiza y compara las distintas posibilidades que la ciencia le brinda para desarrollar su obra artística, pero terceriza o transfiere el trabajo técnico de laboratorio a científicos especializados, es considerado un artista-investigador. 
Uno de los casos más conocidos es el artista Eduardo Kac, que desde la década del ochenta trabaja en la intersección entre arte y tecnología [ver Kac antecedentes] al inventar una categoría conocida como "holopoesía" la cual refiere a la creación de poemas utilizando holografía. En 1986 organiza "Brasil High Tech" en la Galería Centro Empresarial de Río de Janeiro donde exhibe su primera obra telepresencial mediante un robot manejado a radiocontrol que permitía que el público se comunicara entre sí a la distancia. En 1989 presenta Ornitorrinco, un telerrobot que se movía activado por los espectadores a través de la red de telefonía. Continuando con los principios de distancia, conexión y comunicación presenta en 1994 Ornitorrinco in Eden (Ornitorrinco en el Edén) una obra que se exhibe simultáneamente en tres lugares diferentes (Chicago, Lexington y Seattle) a través de una conexión a Internet. Ese mismo año exhibe lo que considera su primera obra biológica Essay Concerning Human Understanding (Ensayo sobre el entendimiento humano) una pieza telecomunicacional concebida para un pájaro, una planta y un ser no humano. En 1996 continúa exhibiendo obras que pueden ser espectadas tanto por un público local como por un público remoto conectado a la red de Internet: Ornitorrinco in the Sahara (Ornitorrinco en el Sahara), Rara Avis y Teleporting An Unknown State (Teletransporte a un estado desconocido). Esta última obra tiene la particularidad de referir a una pieza viva, se trata de una planta ubicada en el centro de una sala oscura que es iluminada con la luz que emite un proyector cada vez que un usuario de Internet hace click en alguna ciudad del mundo donde sea de día en ese momento, de ese modo la planta puede efectuar una suerte de fotosíntesis para vivir y crecer en la oscuridad.

Luego de la controversial performance Time Capsule (Cápsula del tiempo) en 1997 donde el artista se implanta un microchip en su tobillo, vendría la reflexión más aguda respecto del cruce entre arte, ciencia y tecnología. En 1998 publica en la prestigiosa 
revista Leonardo Electronic Almanac un artículo titulado "El arte transgénico", donde expresa lo que estaba ocurriendo en ese momento en el campo de la ingeniería genética y su vínculo con el campo artístico:

Los desarrollos en paralelo de las tecnologías médicas, tales como la cirugía plástica y las neuroprótesis, en definitiva nos han permitido extender esta plasticidad inmaterial a cuerpos reales. La piel ya no es la barrera inmutable que contiene y define el cuerpo en el espacio. Por el contrario, se ha convertido en un lugar de transmutación continua. Además de intentar hacernos cargo de las asombrosas consecuencias de este proceso en marcha, también es urgente que nos planteemos la emergencia de biotecnologías que operan debajo de la piel (o dentro de cuerpos sin piel, como las bacterias) y que, por lo tanto, no son visibles. Más que hacer visible lo invisible, el arte tiene que despertar nuestra consciencia sobre aquello que está firmemente fuera de nuestro alcance visual pero que, sin embargo, nos afecta directamente. Dos de las tecnologías más prominentes que operan más allá de nuestra visión son los implantes digitales y la ingeniería genética, ambas destinadas a tener unas consecuencias profundas en el arte así como en la vida social, médica, política y económica del próximo siglo. ${ }^{109}$

El cruce entre la ciencia biológica molecular y el arte da forma a una nueva categoría que el artista denomina "arte transgénico"

Propongo que el arte transgénico sea una nueva forma de arte basada en el uso de las técnicas de ingeniería genética para transferir material de una especie a otra, o de crear unos singulares organismos vivientes con genes sintéticos. La genética molecular permite al artista construir el genoma de la planta y del animal para crear nuevas formas de vida. La naturaleza de este nuevo arte no sólo es definida por el nacimiento y el crecimiento de una nueva planta o un nuevo animal, sino sobretodo, por la naturaleza de relación entre el artista, el público y el organismo transgénico. El público puede llevarse a casa las obras de arte transgénicas para cultivarlas en el jardín o criarlas como animales domésticos. No hay arte transgénico sin un compromiso firme y la aceptación de la responsabilidad por la nueva forma de vida creada así. Las preocupaciones éticas son de capital importancia en cualquier obra artística y se hacen todavía más cruciales que nunca en el contexto del arte biológico, donde un ser vivo real es la propia obra de arte. ${ }^{110}$

\footnotetext{
${ }^{109}$ Kac, E. (Diciembre 1998). "Transgenic Art". Leonardo Electronic Almanac, vol. 6, (11).

${ }^{110}$ lbid.
} 
Kac había investigado acerca de la técnica de transgénesis y de las proteínas que debían utilizarse para poder ser transferidas de una especie viva a otra. En el artículo de 1998 menciona la GFP (Green Fluorescent Protein), una proteína verde fluorescente que se extrae de la medusa Aequorea Victoria del noroeste del Pacífico y que, transferida a organismos como células de mamíferos, insectos, plantas, col y levadura, se había expresado con éxito emitiendo una luz verde brillante. Su idea por entonces era transferir dicha proteína al genoma de un perro para crear la primera obra transgénica titulada GFP K-9. Kac reconocía que era un experimento ambicioso ya que nunca se había llevado a cabo en laboratorios, pero realmente era importante que su obra fuera un animal doméstico para que pudiera vivir con él, su familia y otros seres no transgénicos, entablando así una comunicación dialógica que expresara realmente lo que significa un arte interactivo.

Hacia fines de los noventa, el curador francés Louis Bec contactó a Eduardo Kac con Louis-Marie Houdebine y Patrick Prunet, un equipo de científicos del Institut National de la Recherche Agronomique-INRA (Instituto Nacional de la Investigación Agronómica) de Francia, para desarrollar el animal doméstico transgénico que anhelaba el artista. Kac estudió cuidadosamente los procedimientos científicos y consideró cualquier daño potencial que pudiera causarle al animal por nacer. Finalmente, luego de un procedimiento exitoso nació en febrero de 2000 una coneja transgénica a la que llamó Alba [figura 58]. Por dicha razón la obra recibiría otro nombre, en vez de GFP K-9 ahora se llamaría GFP Bunny, y contemplaría entre otras cosas la convivencia con la familia del artista en su casa de Chicago en Estados Unidos.

Kac había decidido presentar públicamente a Alba por primera vez en el Festival Avignon Numérique, sin embargo el director científico del INRA decidió no otorgarle la 
coneja causando un gran malestar al artista que consideró que los científicos franceses habían censurado su obra. A partir de allí surgió la serie Rabbit Remix (2000-2011) llevada a cabo en distintos soportes y dispositivos desde dibujos hasta, intervenciones urbanas, esculturas, cerámicas, fotografías digitales, libros de artista, grabados, arte interactivo y trabajos con google earth, ente otros [ver Kac Rabbit Remix].

Aparte de la técnica científica que implica la transferencia de genes entre especies existentes como ocurrió con Alba, en el artículo El arte transgénico, Kac habla de "genes de artista" para explicar la creación de genes sintéticos con fines estéticos:

(...) Además de la transferencia genética de los genes existentes de una especia a otra, también se puede hablar de los "genes de artista", i.e. los genes quiméricos o nueva información genética creada en su totalidad por el artista a través de las bases complementarias A (adenina) y $\mathrm{T}$ (timina) o C (citosina) y $\mathrm{G}$ (guanina). Esto significa que los artistas ahora pueden no sólo combinar genes de especies diferentes, sino que pueden escribir fácilmente una secuencia de ADN en sus procesadores de texto, enviarla por correo electrónico a una instalación comercial de síntesis y en menos de una semana reciben un tubo probeta con millones de moléculas de ADN con la secuencia prevista. ${ }^{111}$

Basado en esta idea crea Genesis, una instalación que presenta un gen sintético producido a partir de la traducción de la frase del Génesis "Que el hombre tenga dominio sobre los peces del mar, sobre los pájaros del aire y sobre todo ser viviente en esta tierra". La frase fue traducida primero a código Morse, una vez convertida en puntos, rayas y espacios se transformó posteriormente en $\mathrm{C}, \mathrm{G}, \mathrm{A}, \mathrm{T}$, los cuatro nucleótidos que forman la base de ADN del gen.

Al obtener la descripción de la secuencia genética envió un e-mail a una compañía especializada en síntesis de genes y dos semanas después, via FedEx, recibió el gen. El paso siguiente fue incorporarlo en una bacteria que se colocó en una placa de Petri

\footnotetext{
${ }^{111}$ /bid.
} 
junto a una cámara de microvideo flexible, una caja de luz ultravioleta y un microscopio iluminador [figura 59]. Estos dispositivos permitían a los espectadores poder efectuar cambios en la bacteria, tanto en la sala de exhibición como a través de Internet.

De manera similar, en Move 36 utiliza la frase de Descartes Cogito ergo sum para crear un gen sintético de cincuenta y dos bases. Una vez obtenida la secuencia genética tercerizó el trabajo para la producción de una planta transgénica [figura 60].

Cuando la obra fue exhibida en Buenos Aires en el 2006, Kac envió por mail la secuencia a un laboratorio de Arizona para realizar la síntesis. Por FedEx se mandó el gen sintético junto a otro gen que provocaba modificaciones en la planta a un laboratorio ubicado en North Dakota, allí se integraron ambos genes y se enviaron a California donde produjeron la semilla transgénica. Este último laboratorio mandó por correo la semilla a la casa del artista en Chicago y este la reenvió a la Facultad de Agronomía en Buenos Aires para que desarrollara la planta para la exhibición.

The Eighth Day (El Octavo Día) es otra obra del artista que consiste en un terrario coronado por una cúpula transparente de plexiglás que alberga una amplia variedad de criaturas transgénicas tales como plantas, amebas, ratones y peces junto a un robot biológico denominado biobot [figura 61]. Este robot posee un elemento biológico activo dentro de su cuerpo que es el responsable de su comportamiento, en este caso, una colonia de amebas que controlan sus movimientos. Los espectadores pueden observar el terrario desde dentro o fuera de la cúpula. Desde afuera, por ejemplo, asistiendo a la galería donde se ubicaba la instalación para mirar a través de la cúpula transparente [figura 62]. Y desde adentro, ingresando a un sitio web específico que se conectaba con una cámara ubicada en el biobot y que permitía ver la interacción de los organismos modificados genéticamente [figura 63]. 
En cuanto a la realización técnica y científica de The Eighth Day, Eduardo Kac hace mención en los créditos $^{112}$ a una larga lista de personas pertenecientes a diferentes instituciones científicas y académicas como Samuel Lunenfeld del Reasearch Institute de Toronto, Richard Firtel de la University of California de San Diego, Chi-Bin Chien de la University of Utah de Salt Lake City quienes estuvieron involucradas en la producción de esta compleja obra.

Otro grupo artístico que representa la figura de artista-investigador es Proyecto Untitled, este colectivo radicado en la Universidad Maimónides ha estado siempre en permanente contacto con los docentes-investigadores de las distintas carreras de la Facultad de Ciencias de la Salud (Bioquímica, Ciencias Biológicas, Farmacia, Ingeniería Biomédica y Medicina), e incluso, con investigadores de otras dependencias como la Universidad de Quilmes o científicos del Instituto del Quemado.

En un principio el grupo trabajaba con el material realizado por los científicos del Instituto Superior de Investigaciones de la Universidad Maimónides. A partir de un desarrollo científico determinado, el colectivo ideaba la producción de una obra artística, como sucedió con Incubaedro (2008-2009) [figuras 64 y 65], Invernadero Lúdico (2008) [figura 66] y Edenia (2010) [figura 67], en donde utilizaron las orquídeas selváticas (Oncidium biofolium, Epidendrum ibagüence) reproducidas por la Dra. Nora Mouso para presentarlas en tres instalaciones cuyo concepto artístico y morfología variaba de una obra a otra.

En el año 2010 se inscriben al Premio que otorga la Bienal Kosice cuyo tema era "Agua, luz y movimiento". Presentan el proyecto Late [figura 68] y ganan la Mención Especial a la Investigación Artística. Para poder llevar a cabo el proyecto se contactaron con la Dra. Marcela Barrios y la Dra. Silvia Galeano quienes los

\footnotetext{
${ }^{112}$ Kac, E. (2004). "El Octavo Día”. En Mungi, A., Elorza, C. y Billabeitia, I. (Eds.), Arte y pensamientos en la era tecnológica. Bilbao: Universidad del País Vasco.
} 
asesoraron acerca de la fertilización asistida y reproducción in vitro. Además colaboraron en la realización de imágenes y videos de pre-implantación embrionaria Florencia Nodar directora asociada del Centro de Estudios de Ginecología y Reproducción (CEGyR), y en la realización de las imágenes y videos de postimplantación embrionaria Noelia Leopardo del Centro de Estudios Biomédicos, Biotecnológicos, Ambientales y Diagnóstico (CEBBAD-Universidad Maimónides). A pesar de no tener injerencia en la manipulación de los embriones, Proyecto Untitled estuvo atento a cada uno de los protocolos, técnicas y desarrollos que fueron utilizados tanto en la pre-implantación como en la post-implantación, así como también participó en la captación de imágenes y videos dirigiendo a los científicos a cargo de las microfilmaciones [ver 回 ].

En el 2012 Proyecto Untitled idea .a priori, un proyecto presentado en la $2^{\circ}$ Bienal Kosice cuyo lema era "Ciudades hidroespaciales". A partir de una reflexión del colectivo artístico sobre cuál podría ser el habitante de esa ciudad, un habitante primigenio y resistente que perdure en el tiempo, pensaron en las bacterias como los primeros habitantes del planeta

Bacterias. Organismos unicelulares procariotas primitivos. De ellos venimos. $Y$ en ellos, que constituyen nuestro pasado y predicen nuestro futuro, estudiamos la forma y el camino de la supervivencia. La referencia original. La esencia, lo infinito de la existencia. La necesidad de volver al origen, de estudiar patrones de modelos primarios para evolucionar, para sobrevivir. ${ }^{113}$

Su idea era crear una ciudad formada por tubos de ensayo, cápsulas de Petri, buretas, matraces, balones, tubos refrigerantes y embudos Buchner que albergara a bacterias inocuas dispuestas en nutrientes que cambien de color a medida que la población bacterial creciera y se reprodujera [figura 69].

113 Proyecto Untitled. (2013). Catálogo "Proyecto Untitled. Arte, ciencia y tecnología". Buenos Aires: Escuela de Diseño y Comunicación Multimedial, Universidad Maimónides, p. 25. 
Con esta obra se buscó reinterpretar el comportamiento del ciclo de la vida, estudiar los patrones evolutivos de las bacterias y su supervivencia con el fin de extrapolarlos al ciclo vital de la sociedad para entender el presente y su futuro. Una manera metafórica de evidenciar una realidad a la que se dirige el ser humano como comunidad.

Para realizar .a priori se pusieron en contacto con bacteriólogos de la Universidad de Quilmes quienes les presentaron una serie de bacterias y sustratos de distintos colores. Proyecto Untitled seleccionó aquellos organismos y sustratos que les parecieron más adecuados para su obra y el equipo de bacteriólogos se encargó de fabricarlos e implantarlos dentro de las cápsulas que componían la instalación.

La obra se completaba con un contador de población que daba cuenta del crecimiento de las bacterias de acuerdo al cambio de las condiciones de cada cultivo [figura 70]. Mediante una pantalla ubicada en la instalación se podía observar en vivo la multiplicación de cada uno de los seis tipos de bacterias y también la cantidad total de población bacteriana.

A medida que pasó el tiempo, tanto Eduardo Kac como Proyecto Untitled se han ido implicando cada vez más con "el hacer" científico, involucrándose en la realización técnica y procedimental de los proyectos. Sin embargo, en estas primeras obras descriptas la tarea de laboratorio fue delegada a científicos especializados para su producción, desarrollo y puesta a punto. Por eso decimos que representan la figura de artista-investigador en cuanto asumen un rol de explorador, indagador y conocedor de las temáticas biocientíficas.

\subsubsection{Artista-divulgador}


El artista-divulgador cumple la función de acercar el conocimiento científico a un público no especializado, provocando la simetrización de los saberes específicos de la ciencia y los saberes habituales de los espectadores. En otros términos, busca establecer un diálogo entre el mundo de la ciencia y el mundo cotidiano a través de la figura de un comunicador no científico. ${ }^{114}$

Ya sea a través una performance donde el propio artista explica a los espectadores los objetivos de la obra (en general vinculados a concientizar o dar a conocer aspectos herméticos de la ciencia), o mediante una instalación donde el objeto instalado es acompañado de gráficos, fotografías, videos y textos que explican el mundo científico; la idea es romper con la jerarquía socialmente instalada entre el que posee conocimiento y aquel que no lo tiene a fin de construir un vínculo simétrico. Para los artistas-divulgadores del bioarte es sumamente importante que el espectador tome contacto y comprenda la incumbencia de la biotecnología en el desarrollo social, cultural, político, económico y medioambiental.

Un artista que ha venido trabajando desde hace tiempo en el área de la divulgación científica es Joaquín Fargas. Con formación en ingeniería industrial, Fargas arriba al campo del arte como consecuencia de la posibilidad de establecer un contacto directo con el público -un público general y no especializado- además de poder utilizar otros recursos, más poéticos, para dar a conocer los saberes que encierra el campo científico. Desde la década del ochenta, se vincula al área del diseño como Presidente del Centro de Diseño Industrial en Buenos Aires (1980-1990), a la música como Director de Studio Arte \& Música en Buenos Aires (1990-1994), al arte cinético como miembro de la KAO (Kinetic Art Organization) donde además obtuvo dos premios en 2003 y 2005, y a la popularización de la ciencia como miembro de la Red Pop-

114 Eliseo Verón distingue entre divulgadores científicos y divulgadores no-científicos (periodistas, presentadores de TV -y agregaríamos nosotros- artistas). Verón, E. (2013). "La autopoiésis productiva de la recepción". La semiosis social, 2. Buenos Aires: Paidós. 
UNESCO (Red para la Popularización de la ciencia y la Tecnología para América Latina y el Caribe) que preside desde 2010. Con estudios que van desde pintura hasta holografía, su vínculo con el arte fue permanente y comenzó a darse a conocer a través de sus primeras esculturas eólicas en donde explica aspectos de la física a partir de objetos artísticos (WindLight, WindCapture, I.F.O. Identified Flying Object). Más tarde comenzó a divulgar aspectos concernientes al cuidado del medio ambiente con Proyecto Biosfera [ver Fargas antecedentes], unas esferas de vidrio herméticamente cerradas que contienen en su interior un ecosistema que necesita de la energía solar para poder vivir y desarrollarse: "Las Biosferas se proponen así como representaciones vivas del planeta tierra. Reproducen los procesos básicos del funcionamiento de la vida". ${ }^{115}$ El énfasis de la obra está puesto en la noción de intercambio, en la interacción como modo de relación entre el artista, la obra y el espectador que recibe una biosfera y debe cuidarla atendiendo a las variables de luz y temperatura que determinan la supervivencia del ecosistema.

La inclusión de nuevas tecnologías dio lugar a obras como SunFlower y Crédito Ambiental/Biogame. Sunflower es una escultura robótica con forma de flor que posee seis pétalos con paneles solares que transforman la energía del sol en electricidad, indispensable para que la flor pueda moverse e iluminarse a sí misma durante la noche. El autor denomina a esta gran escultura centinela del cambio climático ya que permite registrar los cambios climatológicos que se producen en diferentes puntos de la Tierra, brindando esa información a las personas interesadas a través de Internet. La flor está actualmente emplazada en Ushuaia y se planea instalar varias flores en distintos puntos del planeta para relevar los datos climáticos de diferentes lugares.

\footnotetext{
${ }^{115}$ Extraído del sitio oficial del artista http://joaquinfargas.com.ar
} 
Con esta obra se propone generar una conciencia social y comunitaria acerca de la contaminación ambiental y el cambio climático.

Por otro lado, Crédito Ambiental/Biogame es una instalación interactiva que se presenta como ejercicio de reflexión acerca la sustentabilidad del planeta y los recursos que quedarán para las generaciones futuras. Crédito ambiental propone poner un límite al consumo por persona a través de un sistema de créditos limitados donde cada espectador elije que bienes o servicios consumir teniendo en cuenta el impacto irreversible que puede provocar en el planeta y la posibilidad de legar a generaciones futuras un ambiente habitable.

Biogame / Crédito ambiental $>$ Una tarjeta de crédito para comprar menos.

Biogame es un juego donde todos ganamos o todos perdemos, en la vida real lo jugamos casi sin darnos cuenta, llegó el momento de tomar conciencia. ${ }^{116}$

Las obras de Fargas vinculadas al medio ambiente y la ecología dan cuenta de la búsqueda constante por hacer entender al hombre los efectos de su incidencia en el ecosistema natural y la supervivencia de los seres vivos. Esta temática se profundizó y complejizó aún más cuando en 2008 funda junto a Alejandra Marinaro (directora ejecutiva) y Alfredo Vitullo (director científico) el primer Laboratorio Argentino de Bioarte con sede en la Universidad Maimónides. En su rol de director artístico, Fargas comenzó a trabajar con los científicos del área de biotecnología en la producción de nuevas obras que incluían seres semi-vivos constituidos por células cardíacas, epiteliales y neuronales (Inmortalidad, Biowear y Big Brain Project) [figura 71]. La aplicación de técnicas y protocolos de laboratorio en la creación de sus obras acercó al público hacia la nueva ecología del siglo XXI, un mundo de organismos separados

\footnotetext{
${ }^{116}$ Extraído del folleto de la obra.
} 
de su cuerpo de origen que viven de manera tecno-artificial al que resulta difícil acceder si el espectador no pertenece al ámbito de la investigación científica.

Sus obras de bioarte están acompañadas generalmente de un sitio web específico donde se amplía la información técnica, el concepto artístico y el funcionamiento de la obra, además de disponer de un espacio para consultas, preguntas o dudas que permite ampliar y divulgar -o como suele mencionar el artista- "popularizar" los conocimientos científicos.

En una línea similar de concientizar al espectador acerca de la incidencia del hombre en el planeta, Steve Kurtz es un activista que a través de sus obras expone los daños ambientales que se producen a partir de la política tecno-científica que reviste el gobierno norteamericano y que afecta no sólo a esa nación sino también al resto del planeta. Como miembro fundador del colectivo artístico Critical Art Ensemble (CAE), suele cuestionar la falta de ética política y científica con la que se llevan a cabo ciertas investigaciones en el campo de la ingeniería genética y la biotecnología respecto de la producción de alimentos, así como los experimentos militares que involucran armas biológicas.

EnContestational Biology, considerada tanto una obra como un manifiesto ideológico contestatario, propone interrumpir el desarrollo científico de los cultivos transgénicos. Junto a Beatriz da Costa y Claire Pentecost como parte del CAE, realizan una instalación compuesta por plantas transgénicas (Roundup Ready Canola, Roundup Ready Soja y Roundup Ready Maíz) [figura 72] a las que someten a un proceso químico no tóxico para dar marcha atrás a la modificación genética. El Roundup Ready (RR) es un herbicida que mata todo a su paso inclusive los cultivos, por eso la biotecnología desarrolló un procedimiento que modifica genéticamente a las plantas para que produzcan una enzima que las proteja de dicho herbicida. El objetivo de este grupo de 
artistas es desarrollar un producto químico que ponga en evidencia las plantas transgénicas tratadas con RR pero que no las mate, produciendo algún tipo de tinte especial que coloree las células que contienen enzimas activas del $R R$ y así manifestar un color no natural que permita reconocer a simple vista las plantas transgénicas utilizadas para alimentación.

El éxito de este proyecto, señala el CAE,no se reduce simplemente a la creación de un tinte sino que la puesta en acción de todo el concepto se manifiesta como una marca contestataria en el campo, el supermercado y el hogar. Con esto apuntan a convertir las problemáticas de la biotecnología y la transgénesis en una cuestión de dominio público $^{117}$. De este modo, el público general se convierte en el principal componente de las obras de Steve Kurtz y el CAE ya que apuntan en su mayoría a la divulgación, concientización y reflexión del discurso científico. A través de instalaciones, performances, videos o net.art, se intenta desmitificar la idea socialmente arraigada de que la ciencia es demasiado difícil de entender. En el libro The Molecular Invasion, Kurtz refiere a este enunciado y asegura que en un período corto de tiempo cualquier persona medianamente instruida puede aprender los fundamentos del estudio científico y sus principios éticos ${ }^{118}$. Para reforzar esta idea el autor da el siguiente ejemplo:

Los estudios deben obtener constantemente resultados similares. Si cada laboratorio muestra los mismos descubrimientos, entonces la hipótesis o teoría que guía los estudios se dice que es fiable. Fiabilidad es un indicador clave de la prueba de validación. Hasta que los estudios de fiabilidad no están concluidos, un resultado dado es sospechoso. Obviamente, uno no necesita ser un científico para entender que si un estudio no ha sido repetido por fuentes independientes, los datos son cuestionables. Si las únicas repeticiones fueron hechas por el laboratorio (generalmente el

\footnotetext{
117 Critical Art Ensemble; da Costa, B. y Pentecost, C. (2002). "Contestational Biology". Disponible en http://critical-art.net/Original/conbio.

${ }^{118}$ Critical Art Ensemble (2002). The Molecular Invasion el Critical Art Ensemble. New York: Autonomedia, p. 4.
} 
laboratorio es corporativo, pero los laboratorios académicos también son sospechosos) que se beneficiará financieramente, uno no necesita un Doctorado en ética para saber que esto viola los códigos científicos de conducta debido a un conflicto de intereses que podría torcer radicalmente la interpretación de los datos (o los datos en sí mismos). Actualmente, las corporaciones biotecnológicas son las primeras si no las únicas proveedoras de datos a la Agencia de Protección Ambiental y al Departamento de Agricultura de Estados Unidos para permisos de licencia comercial para organismos modificados genéticamente. [Aquí] el discurso amateur tiene claramente un lugar en los debates transgénicos desde que algunos niveles del estudio pueden ser revistos por personas no expertas. ${ }^{119}$

Continuando con los principios de desmitificación de la ciencia y la exposición pública de las políticas corporativistas globales sobre la manipulación genética, surge la obra Free Range Grain [figura 73] diseñada para concientizar al público europeo sobre las políticas económicas de la Unión Europea en relación a las regulaciones y los protocolos de prueba de la comida modificada genéticamente. A través de una instalación preformativa, el CAE acerca al público los procesos rutinarios de la ciencia para que los vean, analicen, practiquen y comprendan.

En Marching Plague divulgan los experimentos científicos en torno a las armas bacteriológicas que se llevaban a cabo en la Segunda Guerra Mundial, y que el gobierno norteamericano ha intentado revitalizar después de lo ocurrido el 11 de septiembre. La obra reúne fotografías y videos que muestran las experiencias del CAE con el uso de armas biológicas, imágenes de archivo de prácticas militares pasadas, y escritos que relatan y difunden todo lo concerniente a la investigación con este tipo de armamento.

El debate del CAE está puesto en el dinero que invierte el gobierno norteamericano en una práctica inútil que solo promueve en la sociedad el miedo irracional. El pánico al ántrax que se había generado durante el gobierno de Bush repercutió en la inversión

\footnotetext{
${ }^{119}$ Ibid., pp. 4 y 5 .
} 
asignada a programas militares, y no al desarrollo de programas de salud pública. La crítica se dirige, además, en que no hay pruebas de que el ántrax se pueda transmitir de un ser humano a otro ser humano. El ántrax es relativamente fácil de hacer y puede parecer bastante virulento, sin embargo los experimentos británicos indicaron una tasa de muertes muy alta en condiciones meteorológicas perfectas, es decir, en ambientes artificialmente controlados como los laboratorios; pero cuando las pruebas se realizan en ambientes normales, un leve movimiento del viento es indicativo para que el arma bacteriológica falle. Por lo tanto la guerra bacteorológica no es útil como tampoco su financiamiento.

Al CAE le parece que canalizar más fondos a la investigación y sobre preparación extrema de una guerra bacteorológica cuando solo existe una modesta posibilidad de un ataque bacteorológico, es un terrible desperdicio de fondos públicos. Estos fondos se utilizarían mejor para tratar de combatir enfermedades como la malaria y el VIH que ponen fin prematuramente a la vida de millones de personas cada año. ${ }^{120}$

En octubre de 2005 Steve Kurtz llevó adelante uno de los experimentos realizados por los militares británicos a mediados de siglo XX para comprobar la inutilidad de financiar el bioterrorismo y la guerra bacteorológica. La "Operación Cauldron" en la que participaron tanto científicos como militares, se llevó a cabo en 1952 en la Isla de Lewis, Escocia, donde se intentó infectar animales (monos y cobayos) liberando gérmenes y bacterias con una bomba ubicada a una distancia considerable. Kurtz llevó a su equipo a la misma isla [figura 74]para recrear la experiencia con treinta cobayos y un cultivo bacteorológico totalmente inofensivo (Bacilus Subtilis) [figuras 75 y 76]. Desde una plataforma ubicada a un kilómetro y medio del bote que albergaba a los

\footnotetext{
${ }^{120}$ La traducción es mía. "It appears to CAE that funneling more funds into germ warfare research and extreme overpreparedness when there is only the modest chance of a germ attack is a terrible waste of public funds. These funds would be better used trying to defeat diseases such as malaria and HIV that prematurely end the lives of millions of people every year." Critical Art Ensemble. (2006). Marching Plague: Germ Warfare \& Global Public Health. New York: Autonomedia, p. 40.
} 
cobayos, se lanzaron bombas con el cultivo bacteorológico mediante un dispositivo de pulverización [figura 77]. Una vez recuperados los cobayos se les tomaron muestras de rastros de Subtilis cuyo resultado fue "tan decepcionante como el experimento original", indicó Kurtz, "demostrando una vez más que las armas bacteorológicas no son sólo una idea estúpida sino también poco práctica."121

Los distintos experimentos y experiencias de Kurtz descriptos a través de sus obras y libros, intentan acercar el conocimiento científico al público no especializado y develar, sobre todo, los mitos, relatos falsos y leyendas que se producen por desconocimiento y que se difunden a través de un discurso hegemónico mediatizado.

Otro caso es el del artista Paul Vanouse quien trabaja sobre la noción popularmente (y mediáticamente) arraigada del $A D N$ como huella dactilar (en inglés DNA Fingerprinting), a través de la cual se puede identificar exclusivamente a un individuo. A lo largo de sus trabajos donde manipula ADN para alterar el resultado visual y gráfico, da cuenta de lo poco fiable que puede ser este procedimiento científico cuando se trata de atrapar, por ejemplo, a un sospechoso. Desde la década del noventa este artista utiliza la tecno-ciencia como medio para realizar obras que incluyen experimentos genéticos que socavan las construcciones científicas acerca de las nociones de raza e identidad.

En la instalación Latent Figure Protocol realiza un experimento en vivo con muestras de ADN para crear imágenes representativas, simbólicas y conocidas por el público general [figura 78]. Para ello utiliza un método científico conocido como electroforésis en gel que utiliza un gel reactivo y corriente eléctrica para separar moléculas y moverlas a diferentes velocidades basándose en su tamaño, forma o $\mathrm{pH}$. El revelado y la

\footnotetext{
${ }^{121}$ La traducción es mía. "Proving yet again that germ weaponry is not only a stupid idea, it is also impractical. No Guinea Pigs are hurt or unnerved during the experiment." Además se aclara que ningún cobayo fue herido durante el experimento.
} 
visualización de este método analítico se realiza mediante la aplicación de colorantes específicos que permiten hacer visibles las distintas moléculas (de ADN, ARN, ribonucleótidos o proteínas). Cuando se mezclan los distintos colorantes se producen separaciones paralelas denominadas "calles", cada calle muestra distintas bandas correspondientes a cada componente de la mezcla, cuando las bandas de diferentes calles se encuentran a la misma altura significa que las moléculas han atravesado el gel a la misma velocidad.

Basado en el conocimiento profundo de esta técnica Vanouse invierte el procedimiento, es decir que, mientras los científicos utilizan técnicas de imagen para determinar la secuencia genética de un organismo, el artista utiliza secuencias conocidas en bases de datos en Internet para producir imágenes "planificadas".

El punto de partida de la obra es una imagen a la que el artista desea arribar, para ello selecciona el tamaño de ADN para cada banda con el fin de moverlo a la velocidad adecuada y así formar la imagen deseada. En Latent Figure Protocol recreó el símbolo de derecho de autor (@) [figura 79], una imagen que para el artista pone en tensión cuestiones éticas vinculadas a la propiedad de los organismos vivos y a la situación cambiante de la vida orgánica a partir de la biotecnología.

Otro caso es Ocular Revision, una variación de la obra anterior en la que el artista diseña y construye la plataforma donde se analiza y visualiza el ADN. Comúnmente el ADN se visualiza en una plataforma rectangular que contiene al gel poroso que es atravesado por el campo eléctrico y que permite desplazar a las moléculas. En este caso Vanouse realiza una plataforma circular [figura 80] para visualizar las bandas de ADN que darán forma a un mapa hemisférico del mundo como imagen simbólica elegida por el autor [figura 81]. Con esta obra intenta cuestionar la idea mundialmente 
establecida de entender el ADN simplemente como un código lineal cuando en realidad se trata de una sustancia biológica altamente manipulable.

Pero donde manifiesta más evidentemente su interés por dar a conocer al público general los aspectos desconocidos del ADN y su análisis científico, es en Suspect Inversion Center, allí trabaja sobre la idea de que el ADN no es como la huella dactilar de una persona sino que su análisis puede variar en muchas formas (sobre todo visualmente), según los diferentes procedimientos utilizados. La idea es poner en evidencia este hecho en lo que respecta a la investigación forense tan difundida mediáticamente por programas como CSI, Bones o Criminal Minds, entre otros. Para ello monta un laboratorio en la Ernst Schering Foundation de Berlin donde el artista y sus colaboradores se dedican a realizar copias de las imágenes del ADN de O.J. Simpson [figura 82] tomadas en vivo de la sala de audiencias del juicio por asesinato a su esposa. Vanouse utiliza su propio ADN y distintas técnicas (algunas utilizadas en obras anteriores) para recrear la misma imagen que produjo el análisis de ADN de Simpson [figura 83].

Suspect Inversion Center invita al público a observar cada paso del proceso de laboratorio e interactuar con el artista y sus colaboradores [figura 84]. De esta manera, se intenta desmitificar la asociación de la imagen del ADN con su asignación a un único sujeto, ya que en realidad la imagen de ADN puede variar en función de cuál de las diferentes pruebas biológicas y enzimas son utilizadas por los laboratorios para fragmentar el ADN y producir el patrón de bandas. Al respecto Vanouse declara estar interesado en corregir el oscurantismo que reviste la práctica científica del estudio de ADN:

Deseo que la gente sea consciente de que el término "DNA Fingerprinting" (identificación por $\mathrm{ADN}$ ) es muy equívoco, ya que el proceso de creación de la imagen de ADN no es la 
marca directa de un individuo, más bien una imagen literalmente "construida" en un laboratorio, mediante procesos de laminado, troceado, ampliación y electroforesis de ADN obtenido de nuestras células. Es más, quiero que la gente comprenda lo discutible que es el poder discriminatorio de esas imágenes (su capacidad de distinguir a un individuo de otro). Esto se debe a que la típica imagen de ADN revela variaciones genéticas en una docena de tramos del genoma más o menos, compuestas por unos pocos miles de parejas de bases nitrogenadas, del ADN de una persona. Por lo tanto es un proceso muy diferente de, digamos, la "secuenciación del ADN" que describe los tres mil millones de parejas de bases nitrogenadas de un individuo. (...) Pero creo que hemos de poner en tela de juicio la manera en que se explica la imagen de ADN en su aplicación en la identificación y el procesamiento judicial de sospechosos. ${ }^{122}$

Para el artista los procesos utilizados por los laboratorios para la obtención de imágenes de ADN son con frecuencia opacos y por ello acerca al público, a través de sus obras, las innovaciones en experimentación genética de una forma más clara y amplia con el fin de cuestionar la forma tradicional de ver la imagen del ADN como algo esencial e inmutable que identifica a un único sujeto como la huella dactilar.

Otro ejemplo de la figura de artista-divulgador es Daniel Álvarez Olmedo quien junto al colectivo@Agua_Y_Aceite realizan obras robóticas para difundir datos estadísticos vinculados a la pobreza en Argentina en relación a la vivienda, la alimentación y la salud. La producción artística del grupo se puede enmarcar dentro de lo que se conoce como arte de base de datos, pues utilizan datos estadísticos provenientes de distintas fuentes (oficiales y extraoficiales) que son visualizados de distintos modos.

El problema de la vivienda se observa en Una de cal y una de arena a través de datos obtenidos del INDEC de la población de los años 1869, 1895, 1914, 1947, 1960, 1970 , 1980 y 1991 de la Villa 31 en Retiro. Estos datos manipulan una serie de servomotores que, mediante su programación, mueven una plataforma formada por tierra, cal y

\footnotetext{
122 Waelder, P. (2013, 19 de marzo). "Entrevista a Paul Vanouse". Fundación Telefónica. Disponible en http://vida.fundaciontelefonica.com/blog/entrevista-a-paul-vanouse.
} 
arena haciendo que estos componentes se mezclen a medida que varían los datos estadísticos.

Estados manipulados I, II y III son tres obras ${ }^{123}$ que permiten reflexionar sobre la confección de datos estadísticos y su uso tendencioso. En este caso la base de datos utilizada es la Encuesta Permanente de Hogares, un programa oficial que revela las características sociodemográficas y socioeconómicas de la población argentina. Esta encuesta permite determinar los grupos sociales que no tienen los recursos económicos mínimos para alcanzar una Canasta Básica de Alimentos (CBA) digna.

La información estadística de la CBA proviene del INDEC, del año 2010 al 2012, y de otros entes institucionales no oficiales durante el mismo período. Esta información activa una serie de robots que se mueven de manera diferente según la fuente estadística: cuando los datos provienen del INDEC el robot se desplaza lentamente simulando un estado de tranquilidad y bienestar; cuando la información proviene de las encuestas realizadas por entes independientes, el robot acelera sus movimientos manifestando un estado alterado, perturbado. La disparidad entre ambas fuentes de información influye en el movimiento contradictorio de los motores de los robots que fuerzan su accionar hasta llegar al límite de poder romperse. Esto pone de manifiesto la problemática existente entorno a los sondeos estadísticos en el país.

Para divulgar el estado del sistema de salud en Argentina, Álvarez Olmedo contó con el asesoramiento de los biólogos Javier Jamui y Alejandra Cahansky, el bioquímico Mauro Fernandez Toscano, y la colaboración del Laboratorio Argentino de Bioarte de la Universidad Maimónides para realizar las obras Generación de conciencia I y II.

\footnotetext{
${ }^{123}$ Daniel Álvarez Olmedo trabaja junto a Diego Diez y Guido Villar, además, recibe la colaboración de Daniel Escobar Vásquez (Colombia) para la producción de estas obras. Estados manipulados I/ y III aún son proyectos que están en proceso de desarrollo.
} 
Generación de conciencia I es una instalación robótica que representa un suero de hospital donde ha sido cambiada la solución fisiológica por un líquido de color rojo que simboliza la sangre de los muertos en Argentina durante los años 1980 a 2007 [figura 85]. El suero está conectado a un dispositivo de válvula de apertura y cierre que limita mediante un goteo el pasaje de líquido a un recipiente con agua que alberga bacterias vivas [figura 86]. Estos microorganismos se aglutinan alrededor de las gotas que caen devorando su composición. Su accionar se transmite a través de un microscopio que capta las imágenes y las proyecta a una pantalla de LCD [figura 87].

Cada gota que cae equivale a mil muertos según la Tasa de mortalidad de la población total del país de los años 1980, 1990, 2000, 2004, 2005, 2006 y 2007, información suministrada por el Ministerio de Salud de la Nación, Dirección de Estadística e Información de Salud [figura 88]. La instalación está dotada de cierta autonomía ya que realiza sus cálculos sobre la información proporcionada por la estadística provocando que en los años de mayor mortalidad el dispositivo goteara más que en los años de menor mortalidad.

Con esta obra se intenta difundir de manera poética el colapso del sistema público hospitalario: "La síntesis en una gota de sangre roja, tomado como identificador simbólico de miles de personas muertas por no contar con una buena atención médica, son gotas devoradas por el sistema de instituciones que solo quieren lucrar con la salud de la gente." 124

Generación de conciencia // es la continuación de la obra anterior e incluso utiliza los mismos datos estadísticos. Esta videoinstalación interactiva está compuesta por un cilindro blanco que alberga un contenedor de acrílico transparente (similar a una

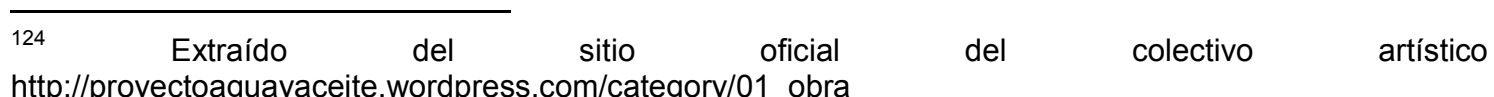


cápsula de Petri pero de mayor tamaño) en cuyo interior reposan los desechos orgánicos que dejan los microorganismos que devoran la composición del líquido goteado en Generación de conciencia I. Sobre el contendor acrílico se proyectan unos videos de microorganismos filmados previamente en el laboratorio y una serie de datos estadísticos activados por los espectadores [figura 89].

Cada vez que un espectador se acerca a la obra, su presencia es captada por un sensor ubicado en la parte cenital. A medida que el espectador avanza hacia el cilindro blanco pasa por encima de una proyección dirigida al piso que muestra tres círculos concéntricos con información que gira constantemente: el círculo exterior es la Zona Año, muestra los años en que se realizaron las estadísticas de la tasa de mortalidad nacional desde 1980 hasta el año 2007. El círculo del medio es la Zona Etaria, los muertos menores de un año, entre uno y cuatro años, de cinco a catorce años, de quince a veinticuatro años, de veinticinco a treinta y cuatro años, de treinta y cinco a cuarenta y cuatro años, de cuarenta y cinco a cincuenta y cuatro años, de cincuenta y cinco a sesenta y cuatro años, de sesenta y cinco a setenta y cuatro años, y mayores de setenta y cinco años. El círculo interno es la Zona Género y se divide en población masculina y población femenina.

Cuando el espectador se detiene en una porción de datos, los círculos dejan de girar y se proyecta sobre el contenedor acrílico el porcentaje por mil de los muertos acaecidos en el país que involucran las tres zonas (año, rango etario, género) [figura 90].

La información suministrada por la misma base de datos oficial, en Generación de conciencia I se visualiza de una manera más poética y metafórica a través del goteado de líquido coloreado, en cambio en Generación de conciencia // la información se presenta de manera literal y directa exponiendo en números la realidad del estado de salubridad en Argentina [figura 91]. 
Los artistas-divulgadores aquí analizados también investigan y, en ocasiones, practican las técnicas y procedimientos de la biotecnología; vale decir que pueden ser categorizados como artistas-investigadores o como artistas-científicos pero a diferencia de estos dos grupos su real preocupación, el motivo que los impulsa a crear esta serie de obras, está dado por el afán de comunicar y transferir al común de la gente los diversos conocimientos que encierra el campo científico. De ahí que buscan generar un diálogo, una simetría, entre el mundo de la ciencia y el mundo cotidiano del espectador. A diferencia del divulgador científico que mantiene una relación asimétrica y complementaria con el público, el rol del artista-divulgador es similar al rol del divulgador no científico, representado por el periodismo de divulgación, que intenta "presentar datos complejos en un lenguaje simple y atractivo" ${ }^{125}$.

Por otra parte, la distinción entre un científico, un periodista y un artista que divulga los saberes de la ciencia, no radicaría en el qué (dimensión temática) pues todos podrían estar hablando de lo mismo, sino en el cómo (dimensión retórica) en los modos en que se exponen esos contenidos científicos. En los casos aquí analizados se observó el uso de dispositivos, técnicas y lenguajes artísticos para dar cuenta de ciertos saberes acerca de la tasa de mortalidad en Argentina, el daño medioambiental, la utilización de transgénicos o el análisis de ADN para la identificación de personas. Todos ellos son temas altamente relevantes para la población general, pues si hay algo que destaca Verón acerca de la divulgación, es su papel fundamental en la sociedad.

(...) hay que hacer divulgación. Porque aun cuando uno no conozca nada, uno se da cuenta de que la ciencia tiene una gran influencia sobre nuestra sociedad, sobre nosotros mismos. Sería catastrófico si por un lado estuvieran los científicos encerrados en su cosa y por otro lado el público. ${ }^{126}$

\footnotetext{
${ }^{125}$ Verón, E. Op. cit., p. 377.

${ }^{126}$ Comentario de un espectador tomado por Eliseo Verón acerca de un estudio de programas televisivos sobre divulgación científica en Francia. Ibid., p. 378.
} 
Para los divulgadores lo importante es el acceso a los saberes científicos, ya sea a través de formas pedagógicas clásicas (libros, cursos, seminarios) o a través de otras formas, como es el caso del arte. El rol que asume el artista-divulgador es el de establecer un diálogo entre la biotecnología y el público no especializado mediante el uso poético del lenguaje científico.

En suma, hemos visto que la noción romántica de artista moderno, vinculado a la centralidad de un sujeto fundante, lo concibe como genio creador de obras únicas a las que deja su huella e impronta personal. En el siglo XX, los estudios estructuralistas y postestructuralistas plantean que no es posible seguir considerando al sujeto como algo autónomo ya que, en todo caso, la subjetividad sería efecto de una estructura que es del orden de lo discursivo. Desde este punto de vista, la noción moderna de artista centrada en el sujeto es desplazada por el surgimiento de "figuras" o "roles" de artista. La determinación de cada uno de estos roles dependen de la producción textual que refieren a los autores y sus obras (críticas, reseñas, entrevistas, biografías, manifiestos, entre otros).

En el caso del bioarte, los textos analizados dieron cuenta de tres figuras de artista que combinan aspectos provenientes del arte y de la ciencia, ellas son artistacientífico, artista-investigador y artista-divulgador.

Como ejemplos de artista-científico hemos visto a Joe Davis, Tagny Duff, Marta de Menezes y el colectivo TC\&A. Estos artistas han trabajado o realizado distintas residencias de investigación en universidades, laboratorios y hospitales de todo el mundo con el objetivo de aprender las técnicas y protocolos necesarios para producir por sí mismos cada una de sus obras. En ocasiones, el aprendizaje y la aplicación de 
saberes específicos colocaron a estos artistas al mismo nivel que un científico especializado.

Como artista-investigador hemos considerado a Eduardo Kac y el colectivo Proyecto Untitled. Son artistas que indagan, analizan y conocen las diversas posibilidades que les brinda la ciencia pero no intervienen en la experimentación científica, ya que tercerizan o transfieren el trabajo técnico de laboratorio para el desarrollo de sus obras.

Finalmente hemos ejemplificado el artista-divulgador con Joaquín Fargas, Steve Kurtz, Paul Vanouse y Daniel Alvarez Olmedo. Estos artistas vienen a cumplir la función de acercar el conocimiento científico a un público no especializado a través del uso de diversos recursos y dispositivos del arte contemporáneo. La idea es lograr un vínculo simétrico entre el científico y el espectador para que el saber no quede en manos de uno solo y sea difundido a toda la sociedad.

Puede apreciarse que ninguna de estas figuras coincide con el concepto tradicional de artista derivado de la modernidad. Si bien los pintores del Renacimiento utilizaban fórmulas matemáticas para componer sus obras o los artistas del Op Art apelaban a ciertos conocimientos de la física para desarrollar sus trabajos, aquí encontramos un vínculo mucho más estrecho con la investigación y la práctica científica en general. Puesto que se trata casi de una superposición del rol del artista con el del científico, del investigador o del divulgador científico, no se verificaría en sentido estricto una muerte o disolución del autor, sino de un desplazamiento hacía una figura mixta o múltiple. En ese sentido podríamos decir que la categoría de híbrido que utilizamos para caracterizar las obras de bioarte es aplicable también a sus propios artistas. 
5. EL ROL DEL ESPECTADOR 


\subsection{Espectador y bioarte. Roles, relaciones, negociaciones}

Las propiedades constitutivas de la obra de arte moderna hacen que las estrategias de expectación así como el rol del espectador fueran previsibles y predecibles. Las modificaciones que introduce el arte contemporáneo tanto en la producción de las obras como en su presentación al público, generan una serie de cuestionamientos e interrogantes dentro del campo de teórico que se dedica a analizar la recepción del arte: ¿De dónde provienen los malentendidos que rodean al arte contemporáneo? ¿Por qué las obras se vuelven confusas e ilegibles para los espectadores? ¿Qué sucede con la interpretación?

Nicholas Bourriaud considera que la mayoría de los críticos y filósofos se niegan a pensar las prácticas contemporáneas en su totalidad, razón por la cual permanecen ilegibles ya que no se puede percibir su originalidad ni su pertinencia si se las analiza partiendo de problemas y cuestionamientos anticuados, algunos incluso ya resueltos por las generaciones precedentes. Lo primero que hay que hacer, sugiere el autor, es reconstituir el juego complejo de problemas que enfrenta una época particular, y en ese sentido, el arte contemporáneo demanda otro tipo de interpretación que el arte moderno. Como señala Smith

La interpretación del arte en su contexto de aparición inmediato supuso siempre ciertas dificultades obvias, situación que el arte nuevo comparte con todos los demás fenómenos de reciente irrupción en el mundo: su carácter naciente, precipitado, inmaduro, incompleto y provisional. A esto se suman otras características relacionadas con aquello que lo diferencia del resto del arte: la novedad, la falta de familiaridad, su rareza y 
demás. Otras dificultades están relacionadas con su lugar de aparición, el modo en que aparece y ante quiénes: su legibilidad, su modo de presentarse, su accesibilidad o su disponibilidad. Se trata de escollos comunes que el trabajo de interpretación debe superar; y lo hace, si bien con distintos grados de éxito.

En el arte contemporáneo, y en especial en el bioarte, la obra rara vez se presenta sola, suele acompañarse con textos de artista algunos más conceptuales otros más divulgativos; textos que describen aspectos productivos como las metodologías y los protocolos científicos seguidos, los requerimientos tecnológicos, los aspectos procesuales de cambio y mutación de la obra; y textos explicativos que describen aspectos receptivos como los modos de funcionamiento y acceso a la obra. Esta complejidad textual a la que además se le añaden otros textos como críticos y curatoriales, completan el universo interpretativo del espectador.

No obstante, las obras de bioarte presentadas a través de dispositivos contemporáneos como instalaciones, intervenciones, ambientaciones, eventos participativos y performances requieren diversas demandas por parte del espectador, no sólo de visualización e interpretación sino también de negociación e intercambio. Esta clase de obras se presentan como una duración por experimentar, una apertura posible hacia un intercambio ilimitado entre el artista y el espectador en donde el artista le exige al espectador distintos grados de participación al negociar con él relaciones más o menos abiertas. ${ }^{127}$ De este modo, las obras de bioarte establecen nuevos espacios de negociación e intercambio constituyendo diversos modelos de relaciones sociales en donde el lugar asignado al espectador oscila entre observador, testigo, invitado, intruso, protagonista o coproductor de la obra.

${ }^{127}$ Bourriaud, N. Op. cit., pp. 14-ss 


\subsubsection{Espectador-observador}

La figura de espectador-observador es la más cercana al arte tradicional ya que plantea la menor participación del espectador con la obra. Sin embargo, las competencias que el bioarte exige al espectador para su comprensión dan cuenta de la problemática contemporánea sobre la interpretación y legibilidad de la obra.

Ejemplo de esto es la obra de Verena Kaminiarz May the mice bite me if it is not true (Pueden morderme los ratones si no es verdad) donde el espectador sólo puede observar el registro de un procedimiento experimental al que pudo acceder únicamente la artista y el grupo de científicos que ayudaron en el desarrollo.

La obra de Kaminiarz se basa en ciertas investigaciones científicas donde el objetivo es crear ratones que modelen sistemas humanos a través de la introducción de ADN humano en el genoma del animal para producir ratones transgénicos que reaccionen a los experimentos de una manera más humana. Con esta obra expone una crítica al mundo de los animales de laboratorio hechos "a medida" desde el seno mismo de la producción científica.

Las personas que estaban autorizadas a ingresar al recinto donde vivían los ratones debían cumplimentar severas normas de higiene y bioseguridad como usar cofia, botas, guardapolvo, guantes descartables, respetar el tiempo de apertura y cierre de las puertas de acceso, y no registrar a través de ningún medio o dispositivo el desarrollo del proceso (con excepción de la artista).

Durante tres meses la artista observó y cuidó de los ratones como parte de la obra: los alimentó, los ejercitó en cintas mecánicas y les construyó una casa con muebles, escaleras y ruedas giratorias [figuras 92 y 93] para que tuvieran una vida más digna a pesar del inevitable final que tienen todos los animales de laboratorio. La relación 
generada entre la artista y los ratones fue documentada diariamente por Kaminiarz en una bitácora que incluía fotografías, videos, dibujos y bocetos [figura 94].

Una vez que los ratones cumplieron su ciclo de vida en el marco experimental del laboratorio y fueron sometidos a un método de eutanasia, Kaminiarz tomó un molde de los cadáveres y produjo la obra Death Masks (mus musculus) (Máscaras mortuorias de ratón común) que acompaña a la obra anterior [figuras 95 y 96]. Creó setenta y ocho piezas escultóricas como forma de registro visual de la fisonomía individual de cada ratón, aspecto fundamental en la concepción de su trabajo pues considera que esta individualización rompe con la visión tradicional de considerar a los animales de experimentación como un número estadístico, un conjunto de herramientas inagotable en la investigación científica.

Los registros visuales y audiovisuales que componen la obra May the mice bite me if it is not true fueron exhibidos en la UWA desde 2008 hasta 2011 (tiempo de vida estimado de los ratones en condiciones normales). El público que visitaba la obra, entre ellos estudiantes, científicos, artistas, historiadores del arte, críticos, curadores y público general, solo se remitían a observar los documentos del proceso de vida de los ratones Félix, Joseph, Gilles y Franz. Su presencia no modificaba ni el tiempo ni el espacio de la obra pero creaba una situación que seguramente obligaba a preguntarse sobre las convenciones científicas, las prácticas artísticas biológicas y las implicaciones éticas y filosóficas del cruce entre disciplinas.

Otro trabajo que problematiza la intersección entre el arte y la ciencia es Move 36 (Movimiento 36) de Eduardo Kac. La obra se exhibe como una instalación que aborda una partida de ajedrez. En el centro de la sala se erige un tablero hecho de tierra para los casilleros negros y arena para los casilleros blancos, no hay ninguna pieza de ajedrez sobre el tablero, únicamente una planta de hojas rugosas ubicada en el 
casillero donde Deep Blue (la computadora que le ganó a Kasparov) hizo su movimiento 36 .

La planta que se exhibe es una planta transgénica creada a partir de lo que el artista denominó "gen Cartesiano", una secuencia genética artificial que transcribe la frase Cogito ergo sum de Descartes. Las letras que forman la palabra fueron pasadas primero a código ASCII (código binario) y luego a código genético ( $A, C, G, T)$. El resultado fue la constitución de un gen artificial que fue incorporado en la semilla de una planta de hojas planas junto a otro gen que provoca curvaturas. En aquellos lugares donde a simple vista se podía observar la ondulación de la planta se encontraba presente el gen Cartesiano. La instalación se completa con dos pantallas enfrentadas que simulan tableros de ajedrez cuyas casillas son loops animados digitales [figura 97].

Aquí el espectador no tiene posibilidad de participar en la partida, no es un jugador ni siquiera un fantasma de aquel, cada elemento dispuesto en la sala tiene una función está allí esperando que el espectador lo contemple, lo interprete y tal vez establezca un juicio crítico; pues para el artista esta obra provoca un "Jaque mate a las nociones tradicionales, la naturaleza se revela como un espacio para la producción de los conflictos ideológicos y las ciencias físicas como un lugar para la creación de ficciones científicas". ${ }^{128}$ El lugar del espectador no es el de Kasparov ni el de Deep Blue sino el de un observador que reflexiona acerca de los límites entre lo vivo (animales, vegetales, humanos) y lo no vivo (máquinas, redes), entre lo artístico y lo científico, entre lo real y lo ficcional.

Al igual que Eduardo Kac, George Gessert se interesó tempranamente en el trabajo con ADN para la producción artística. Comenzó a crear seres híbridos partiendo de

\footnotetext{
${ }^{128}$ Kac, E. (2004). "Move 36”. Disponible en http://www.ekac.org/move36.html
} 
técnicas que se aproximaban a una ingeniería genética pero de baja tecnología. Para Gessert, los cruces genéticos provocados por el hombre provienen de hace miles de años: la domesticación de mascotas, plantas, animales con fines deportivos o variedades vegetales con fines medicinales constituyen una suerte de "arte genético primitivo" ${ }^{129}$. El artista "domestica" y reproduce su propia variedad de plantas con fines estéticos desde 1982, momento en que empezó a hibridar variedades silvestres de lirios de la Costa Oeste del Pacífico de los Estados Unidos. La tarea consistía en cruzar y cultivar las semillas, esperar su crecimiento, florecimiento y observar detenidamente cada una de las flores con el objetivo de seleccionar solo las que presentaban colores brillantes en sus nervaduras y hojas con bordes lisos. Aquellas flores que no presentaban tales características eran desechadas y el resto se guardaban para nuevas cruzas. La decisión de conservar unas plantas por sobre otras se debía a una elección tanto estética como política, pues no solo producía plantas con colores atractivos sino que se trataba de una manera de reaccionar contra la industria de los criaderos de flores comerciales que buscaban reproducir pétalos ondulados en todas las especies florales.

En 1985 realizó su primera exhibición artística de los lirios hibridados y en 1988 hizo su primera presentación en San Francisco con una obra llamada Iris Project [figura 98]. Las plantas presentadas allí se basaban en las mezclas genéticas que realizaba el artista, una "selección estética" que afectaba a la evolución de la especie vegetal. En este sentido, Gessert se interesó en el trabajo de Darwin, especialmente, en el primer capítulo del Origen de las especies donde el científico reconocía a la estética como un factor evolutivo.

\footnotetext{
${ }^{129}$ Wilson, S. (2002). Information Arts. Intersections of Art, Science, and Technology. Londres: MIT Press, p. 96 .
} 
Con Iris Project, el artista había prometido a los organizadores de la muestra que exhibiría cuarenta y cinco plantas florecidas en vivo. Luego de llevar las macetas con los lirios a la galería New Langton Arts de San Francisco, una ola de calor azotó la región impulsando la temprana subida de la temperatura, esto provocó que las plantas florecieran antes del día de la inauguración. Como consecuencia de ese inesperado hecho, Gessert exhibió cuarenta y cinco macetas con tierra negra que presentaban unas largas hojas acintadas pero ninguna flor.

En cuanto a Tagny Duff, la artista estuvo alrededor de un año desarrollando en los laboratorios de la UWA Living Viral Tattoos (Tatuajes Virales Vivos) donde explora, por un lado, la práctica científica de marcar el tejido celular, y por el otro, la práctica cultural de marcar el cuerpo humano a través del tatuaje. En su obra propone materializar en forma de tatuajes virales vivos el movimiento y la interrelación entre retrovirus, tejido humano y tejido animal. Con esta obra se pone en evidencia las preocupaciones en torno a la naturaleza del material biológico y a la bioseguridad pública, los tatuajes virales vivos expresan la ansiedad y la tensión social que se manifiesta respecto de las pandemias, las infecciones y el contagio viral.

En este caso la artista utiliza un lentivirus que une a células primarias humanas y colorea con un antígeno. Por medio de la técnica de transfección introduce este material genético a un trozo de piel de cerdo que se exhibe dentro de un frasco transparente relleno de paraformaldheído [figura 99]. El desarrollo y la proliferación del virus se puede ver en la piel del cerdo gracias al tinte del antígeno que posibilita la manifestación de manchas de color rojo violáceo.

Otro artista que produjo sus organismos vivos en el marco de un programa científico es el chileno Allan Jeffs. En febrero de 2012 viajó a la estación Pevima en la Antártida para desarrollar el proyecto Ex-Sistencia que consistía en una instalación formada por 
esculturas ubicadas en ocho puntos de la Antártida y realizadas a partir del tejido producido por comunidades ecuatorianas. A través de la colaboración de los científicos del Instituto Antártico Ecuatoriano (INAE) la propuesta artística se amplió e incluyó el desarrollo de microorganismos vivos con un fin estético. Con ayuda del biólogo Javier Caravajal cultivaron microorganismos que viven en los glaciares y que presentan un interesante ciclo de vida debido a los sucesivos congelamientos y descongelamientos. Según los microbios utilizados se pasó por un proceso de incubación a determinadas temperaturas creando diferentes formas y colores en el medio nutritivo que los sustentaba [figura 100]. Por otra parte, con los científicos de la estación ecuatoriana Pedro Vicente Maldonado en la isla de Greenwich, Jeffs aprendió a extraer los microorganismos que viven en la superficie de la piel.

De regreso a Guayaquil, lugar donde reside habitualmente, decidió exhibir la instalación escultórica Ex-Sistencia, pero esta vez incorporando los conocimientos científicos aprendidos en la Antártida. Para ello volvió a visitar las comunas de artesanos ecuatorianos para extraer los microorganismos de la piel de doce mujeres, particularmente, aquellos que viven en las manos de estas tejedoras textiles. Los microorganismos fueron colocados dentro de placas de Petri e introducidos en una incubadora durante siete días para que crecieran y pudieran ser visibles. Los microorganismos fueron manipulados para producir formas, colores y letras que formaban la frase "Aquí estoy contenido, con mi piel en tus ojos siendo una trampa a tu mirada. Soy lo que esperas que sea? Estoy aquí?" [figura 101].

La instalación completa formada por las esculturas que viajaron a la Antártida, las cápsulas de Petri y las fotos de las doce mujeres que donaron sus microorganismos, fue exhibida en el Museo Antropológico de Arte Contemporáneo de Guayaquil [figuras 102 y 103$]$. 
El espectador-observador que se para frente a estas obras, o a lo sumo las rodea, se acerca, o se aleja, ve a simple vista unas imágenes de ratones, una planta en un tablero de ajedrez, unas macetas con plantas distribuidas en el piso, unos frascos con piel en su interior o unas cápsulas de Petri con palabras.

El simple hecho de mirar no alcanza aquí para comprender la obra, y no nos referimos a hallar una respuesta, buscar que la obra sea transparente para que refleje el mundo o sencillamente que le dé tranquilidad al espectador; sino que los objetos materiales presentados en la sala son solo una parte de la obra, la misma se completa con la idea que tuvo el artista para crearla, los motivos, objetivos, problemáticas que lo impulsaron a su producción, los aspectos técnicos y metodológicos implícitos, etc. Razón por la cual Javier de Lorenzo considera que es una exigencia de esta época que el espectador esté preparado para poder interpretar la obra.

...desde mi convicción, ciencia y arte se me presentan como
manifestaciones, praxis o haceres diferentes, aunque por ser
producciones de individuos de una misma especie en la que se
obtienen unos productos, muestran algo común: se hacen,
como todas las demás producciones y trabajos, con unas
finalidades. (...) Quiero decir: como haceres en sí, diferentes al
igual que los productos que en esas producciones se obtienen;
con finalidades específicas también diferentes. Pero son
producciones -como tantas otras- que siempre se realizan con
finalidades generales que, desde mi punto de vista, son
esencialmente pragmáticas y exigen, por supuesto, de alguien
a quien van dirigidos los productos correspondientes. Es decir,
son producciones que exigen espectadores que han de tener,
para ser auténticos espectadores, una preparación conveniente
que les posibilite "apreciar" el producto. ${ }^{130}$

Por ello, cuanto más informado y especializado sea el espectador que observa estas obras mayor serán los "mundos develados" que obtenga pero también los cuestionamientos y juicios críticos que le provoquen vinculados seguramente a la ética

\footnotetext{
${ }^{130}$ de Lorenzo, J. (2010). "La noción de estilo en matemática y arte". En S. Castro y A. Marcos (Eds.), Arte y Ciencia: mundos convergentes. Madrid: Plaza y Valdés editores, pp. 235-236.
} 
y bioética, a los límites entre lo artístico y lo científico, y a las prácticas sociales y culturales contemporáneas.

\subsubsection{Espectador-testigo}

Luego de que las vanguardias introdujeran nuevos elementos a la práctica artística los soportes tradicionales como la pintura o la escultura comenzaron a expandirse y a incorporar otros lenguajes tales como la danza, el teatro, la música y el video. Hacia fines de la década del cincuenta la materia de algunas obras era transformada en energía y movimiento dando origen a lo que se denominó arte como acción. ${ }^{131}$ La obra de Allan Kaprow 18 happenings en 6 partes fue el inicio de la incorporación de público general a los actos en vivo que los artistas solían hacer de manera privada para sus amigos. Kaprow consideraba que "ya era hora de aumentar la 'responsabilidad' del observador" ${ }^{132}$ y por ello decidió incluir al espectador en una nueva experiencia temporal, y sobre todo espacial, al expandir tanto la obra que la volvió inseparable de su entorno extra artístico ${ }^{133}$ tornando difuso el límite entre obra y no-obra. Esta nueva dimensión espaciotemporal de la obra performativa que incluye tanto al artista como al espectador es para Bourriaud la esencia del arte contemporáneo. ${ }^{134}$

Las artes performativas son ante todo artes del tiempo, artes efímeras que necesitan materializarse de alguna manera para poder perdurar. Los registros fotográficos y videográficos son el medio más usado para dar cuenta de la acción en vivo pero también la presencia del público en tanto espectador-testigo se convierte en una suerte de escribano que autentica y da fe de la acción que allí ocurre, su experiencia

\footnotetext{
131 Lippard, L. (2011). "La desmaterialización del arte”. En R. Alonso (Curador), Sistemas, acciones y procesos 1965-1975. Buenos Aires: Fundación Proa, p. 106.

132 Goldberg, R. (2002). Performance art. Barcelona: Destino, p. 128.

133 Lippard, L. Op. cit., p. 106.

134 Bourriaud, N. op. cit., pp. 57-58.
} 
real con la obra como testigo directo contribuye al reconocimiento y perdurabilidad de la obra a lo largo de la historia.

Por ejemplo, la obra Bio-Wear de Joaquín Fargas fue desarrollada en etapas. La primera consistió en una performance realizada en el hall del Teatro San Martín de la ciudad Buenos Aires donde el artista tomó una muestra de su propio tejido epitelial [figuras 104 y 105]. ${ }^{135}$ La acción en vivo realizada en la zona más transitada del teatro fue observada tanto por los espectadores que fueron especialmente a ver la obra como por aquellos otros que estaban de paso hacia otros lugares del teatro. De manera casual o informada, todos ellos participaron en la obra como testigos del doloroso proceso de incisión y extracción con bisturí de tejido epitelial del brazo del artista, además de presenciar el momento en que las células fueron colocadas en un recipiente estéril y transportadas rápidamente al Laboratorio Argentino de Bioarte para

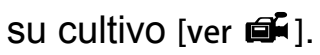

La siguiente etapa de la obra, aún en proceso, comprende la producción de una segunda piel, una metadermis desarrollada biotecnológicamente que reproduce y reelabora procesos del cuerpo como la exudación, respiración, secreción y regeneración. La idea del artista es devolverle a la piel la función de vestimenta natural, algo que conservan los animales pero que el hombre ha perdido a lo largo de miles años de evolución y aculturación.

La serie de performances Inthewrongplaceness (En la territorialidad equivocada) de Kira O'Reilly se desarrolla de modo inverso a Bio-Wear. La artista comenzó cultivando su propio tejido de piel junto al tejido de piel porcina durante una residencia de ocho

\footnotetext{
135 Otras performances similares son las cirugías realizadas por la artista Orlan para La reencarnación de Santa Orlan y Harlequin Coat, aunque en estos casos el público general no participa. También, Time capsule de Eduardo Kac fue una performance donde el artista se implantó un microchip, si bien había público invitado, la performance fue realizada casi con exclusividad para los medios masivos de comunicación que registraron y transmitieron en vivo la colocación del implante.
} 
meses en el laboratorio Symbiotica [figura 106] donde trabajó con cerdos recién muertos usados para la investigación médica. La artista manifestó una extraña sensación al abordar la biopsia para extraer las células de la piel del cerdo

Cuando corto el cerdo tengo el deseo de hurgar con las dos manos dentro de su vientre, de fundirme con su cálida carne, mi sangre y su sangre, por un momento la misma temperatura antes de que baje el cataclismo ${ }^{136}$

El trabajo con cadáveres de cerdo implicaba la disección, el cultivo, la nutrición y el mantenimiento de las células. La artista tomó algo que se sentía muerto y a partir de su cultivo y cuidado pudo dar vida a esos pequeños fragmentos celulares que ahora se manifestaban como organismos semi-vivos. La labor diaria con estos cultivos le provocaron a O’Reilly “(...) fantasías inesperadas de metamorfosis, combinación e interacción entre especies que comenzaron a parpadear en mi conciencia." 137 Así surgieron la serie de performances Inthewrongplaceness llevadas a cabo desde 2005 hasta 2009 donde la artista interactúa con un cerdo recién sacrificado.

En las performances O'Reilly se presenta desnuda, se mueve lento, camina, gira, parece bailar con el animal de piel pálida similar a ella [figura 107]. Introduce su cabeza dentro del cuerpo del cerdo, la sangre se mezcla con su sudor, los gérmenes de ambas especies se transportan de un cuerpo a otro. Los espectadores se ubican muy cerca de la acción, a menos de un metro, anulando prácticamente los límites entre el espacio ficcional de la performance y el espacio real del espectador. Aunque solamente observa la situación, el espectador queda involucrado en un encuentro íntimo al convertirse en testigo ocular de la relación entre especies.

\footnotetext{
${ }^{136}$ La traducción es mía. "When I cut pig I have an urge to delve both hands into the belly, to meld into her warm flesh, my blood and her blood, for a moment the same temperature before one lowers cataclysmically". O'Reilly, K. (2006). "Inthewrongplaceness". Disponible en http://www.artsurgery.org/Tract\%20live\%20art/Kira\%200\%27Reilly/Kira\%200\%27Reilly.html

${ }^{137}$ La traducción es mía. "(...) unexpected fantasies of mergence and interspecies metamorphoses began to flicker into my consciousness." Ibid.
} 
Otra obra de acción en vivo que involucra la relación entre ser humano y cuerpo animal es Disembodied Cuisine (Cocina incorpórea) de TC\&A, basada en la idea utópica de producir carne sin sacrificar a ningún animal. Los artistas montaron en la exhibición L'art Biotech de Francia un laboratorio ambulante para desarrollar pequeños filetes de carne de rana. El laboratorio se ubicaba dentro de una carpa iglú estéril que contenía unos vanos circulares por donde los espectadores podían ver la acción [figuras 108 y 109] que se ofrecía como una suerte de “(...) vista a los tableaux vivants de las operaciones del laboratorio" ${ }^{138}$ El procedimiento realizado en vivo en la galería consistía en la extracción de células de músculo de rana para ser cultivadas sobre una estructura polimérica que daría forma a los filetes de carne.

El cultivo tisular creció en la galería durante varias semanas alimentado por los artistas y alojado en un biorreactor giratorio que otorgaba volumen a las pequeñas "esculturas semi-vivas". Días antes del cierre de la exhibición, momento en el que se llevaría a cabo la performance final donde serían cocinados y comidos los filetes, los artistas asistieron al mercado local para invitar a los carniceros a presenciar el desarrollo de una carne alternativa que no sacrificaba animales [figura 110]. El folleto decía lo siguiente:

Domingo 4 de mayo de 2003. L'art Biotech' Nouvelle Cuisine. En ocasión del cierre de la exposición l'Art Biotech', los artistas australianos de SymbioticA / TC\&A tienen el honor de invitarlos a la degustación de un menú especialmente elaborado para el público francés: la última Nouvelle Cuisine. Pequeños polímeros rellenos de células de Xenopus y su aliño nord et sud a la Davis flambeados con calvados, rematados con pequeños trozos de cultivo tisular de ciboulette y hierbas variadas.

El chef cocinará a las 17 horas.

La cena se llevará a cabo alrededor de las 18 horas.

\footnotetext{
${ }^{138}$ La traducción es mía. "(...) view of the tableaux vivants of the lab's operation”. Hauser, J. op. cit., p. 186.
} 
El laboratorio iglú estaba conectado por un pasillo a un cuarto rectangular transparente donde estaba dispuesta la mesa para los comensales (artistas, científicos y curadores). El público que asistió al evento pudo observar todos y cada uno de los pasos de esta performance como la extracción del cultivo, la preparación de los filetes, la cocción, la cena y la liberación de las ranas en el jardín botánico cercano [figuras 111 y 112]. Una vez concluida la performance se dispuso como documentación un video tríptico titulado The remains of the disembodied cuisine (Lo que queda de la cocina incorpórea) [figura 113].

En estas tres obras, como en tantas otras obras preformativas y efímeras, aunque queden registros gráficos o videográficos de las acciones, la presencia real del espectador lo convierte en un testigo, en otras palabras, en un experto cualificado para dar testimonio de los hechos ya ocurridos.

\subsubsection{Espectador-invitado}

La participación de los espectadores en happenings, performances, ambientaciones, intervenciones, e incluso, instalaciones se ha vuelto una constante en la práctica artística contemporánea. Para Bourriaud ${ }^{139}$ cada vez son más las obras exhibidas en galerías, museos o bienales que presentan un contrato preciso con el espectador otorgándole una propuesta de participación "al que mira". El espacio de intervención del espectador en la obra de arte se resuelve dentro de una cultura de lo interactivo que va más allá del dominio del arte: "en todos los vectores de la comunicación la parte de la interactividad crece cuantitativamente" 140 debido principalmente al desarrollo de las nuevas tecnologías de la comunicación y la imagen, pero también por

\footnotetext{
${ }^{139}$ Bourriaud, N. Op. cit., p. 27.

${ }^{140}$ Ibid., p. 28.
} 
el deseo colectivo de crear otros espacios de sociabilidad e instaurar nuevos tipos de transacción frente a la obra. ${ }^{141}$ Para Graham Coulter-Smith ${ }^{142}$ tanto Estética Relacional de Bourriaud, como La muerte del autor de Barthes, Teoría de la vanguardia de Bürger o Installatation Art: A Critical History de Bishop, son todos textos que apuntan hacia la importancia de deconstruir la barrera entre el espectador y la obra de arte con el fin de lograr un antiguo objetivo vanguardista: el de incorporar el arte a la vida cotidiana.

Las instalaciones permiten romper la barrera entre el espectador y la obra de arte al invitar al espectador a transitarla, atravesarla, y en algunos casos, intervenirla, reforzando así el rol primordial que juega el espectador en la obra. Coulter-Smith señala que las instalaciones digitales interactivas son las que posibilitan realmente vincular al espectador con la obra de arte mediante interfaces o dispositivos de entrada de datos. De esta manera el espectador es invitado a interactuar con la obra, a ejercer formas de acción social comunicativas con las producciones artísticas del mismo modo que lo hace con otros sujetos o con otros textos. ${ }^{143}$ Interacción e interactividad son dos términos que para Gianfranco Bettetini implican un vínculo comunicativo que parte del sujeto, en el primer término, y que parte de la máquina, en el segundo. Por lo tanto, el espectador-invitado se involucra principalmente con obras tecnológicas interactivas que requieren de la cooperación del sujeto para su funcionamiento.

La obra Génesis de Eduardo Kac consiste en una instalación que presenta un gen sintético producido a partir de la frase bíblica del Génesis "Que el hombre tenga dominio sobre los peces del mar, sobre los pájaros del aire y sobre todo ser viviente en esta tierra". La frase fue traducida primero a Código Morse y luego convertida en la base de ADN de un gen. La bacteria portadora de ese gen sintético fue colocada en

\footnotetext{
${ }^{141}$ Ibid., p. 28.

${ }^{142}$ Coulter-Smith, G. (2009). Deconstruyendo las instalaciones. Madrid: Brumaria, p. 85.

${ }^{143}$ Bettetini, G. (1996). Las nuevas tecnologías de la comunicación. Buenos Aires: Paidós, pp. 16-17.
} 
una placa de Petri junto a una cámara de microvideo flexible, una caja de luz ultravioleta y un microscopio iluminador. Estos dispositivos permiten que los espectadores puedan efectuar cambios en la bacteria y observarlos seguidamente. El proceso se realiza a través de una conexión a internet que posibilita que tanto los espectadores que visitan la muestra (donde hay una computadora instalada en la sala) [figura 114] como aquellos usuarios remotos conectados a la página del artista puedan interactuar con la obra al hacer click en un link que permite encender la luz ultravioleta que logra la mutación de la bacteria [figura 115].

Cuando la muestra finaliza y se vuelven a traducir los diferentes códigos (del código genético al Morse y luego al alfabético), la frase original cambia producto de la intervención del espectador [figura 116].

La obra Invernadero lúdico del colectivo argentino Proyecto Untitled es una instalación interactiva que simboliza un ecosistema del siglo XXI: un invernadero biotecnológico formado por orquídeas cultivadas in vitro.

El espacio exhibitivo donde se emplazó la obra fue detrás de una gran vidriera transparente que permitía ver la instalación e interactuar con esta a través de un vidrio. Esta barrera cristalina recuerda a aquellas herramientas y materiales de laboratorio, como las cabinas de bioseguridad o las cápsulas de Pertri, que median y aislan de la contaminación a los objetos manipulados.

De este modo, sobre el vidrio que separaba el espacio interior de la obra con el espacio exterior donde se encontraba el público se colocaron tres sensores fotoeléctricos que se activaban cuando la mano del espectador bloqueaba la entrada de luz [figura 117]. Al detectar un nivel mínimo o nulo de luz, cada sensor disparaba una señal que accionaba: un ventilador cuya función era imitar el movimiento del viento; una bomba de agua que recreaba la caída de lluvia; y una roldana que sacaba de 
adentro de una semiesfera de acrílico una orquídea in vitro en alusión al nacimiento de un neo-organismo de diseño.

Esta propuesta de participación efectiva que tiene el visitante con Invernadero lúdico así como con Genesis, genera un vínculo entre el espectador y la naturaleza manipulada que apunta al interés por invitar al hombre a tomar conocimiento, reflexionar y participar en una nueva realidad transformada, propia del siglo XXI.

\subsubsection{Espectador-intruso}

El público que participa en obras procesuales o comportamentales pone en juego un sistema de intercambio que tiene que ver con las decisiones que debe tomar en relación a la obra. Las producciones artísticas se presentan como un lugar de cohabitación con el público donde se pone a prueba el comportamiento del espectador que debe ser conciente del contexto en el que se encuentra y de la propuesta de la obra. Jacques Rancière destaca la participación activa del nuevo espectador en contraposición al espectador clásico que sólo observa de manera voyeurista e inmóvil: la obra no debe volver pasivos a los espectadores pues entonces estaría traicionando su esencia comunitaria. ${ }^{144}$ Es así, que la obra contemporánea se compromete con el público desde lo físico hasta lo mental, generando la toma de decisiones que incumben en el accionar corporal e intelectual del espectador.

En este caso, las obras comprueban el comportamiento ético del espectador que actúa como un intruso al interferir en el desarrollo normal de la obra, ya sea porque con su intervención la hace desaparecer, detiene la evolución del ciclo vital de los organismos o provoca algún tipo de catástrofe.

${ }^{144}$ Rancière, J. (2008/2010). El espectador emancipado. Buenos Aires: Manantial, pp. 11-15. 
La obra Late del colectivo Proyecto Untitled es una instalación interactiva formada por nueve cubos de vidrio rellenos de agua en donde se proyecta el crecimiento y desarrollo de un embrión hasta la fase de feto. Las imágenes muestran unas nueve semanas de vida desde el momento en que se fertiliza artificialmente el óvulo hasta el avance de la gestación mediante filmaciones de embriones ${ }^{145}$ y animaciones 3D de ecografías prenatales. Las imágenes se complementan con el audio tomado de las ecografías correspondientes a cada uno de los períodos gestacionales que muestran los videos.

El desarrollo de la instalación es normal mientras no haya espectadores cerca: el embrión evoluciona, crece dentro de los cubos con agua que le otorgan un marco de protección ideal (en clara alusión al útero materno) y el sonido acompaña paulatinamente este proceso de embriogénesis. Sin embargo cuando un espectador se acerca demasiado a la obra los sensores de movimiento se disparan actuando como alarmas que tratan de disuadir a quien está acechando [figura 118]. La interferencia del visitante provoca la reversión del proceso, los embriones frenan su evolución decreciendo semana tras semana hasta alcanzar nuevamente el momento de la fertilización, su origen.

La obra interactiva necesita del espectador para su funcionamiento pero aquí el espectador es rechazado, su interacción es intrusiva y la obra responde reaccionando severamente ante tal intromisión. El visitante obstaculiza con su presencia el proceso natural de la evolución del embrión que, paradójicamente, ha sido gestado bajo circunstancias no naturales siguiendo los protocolos de un procedimiento artificial.

De esta manera, Late expresa el conflicto permanente que manifiesta lo natural cuando se combina con lo artificial sugiriendo que, así como el hombre y la tecnología

\footnotetext{
${ }^{145}$ Para la filmación de esta etapa gestacional se utilizaron embriones de vizcacha por su gran parecido con los embriones humanos.
} 
pueden dar origen a la vida de un ser también es el hombre y la tecnología los que pueden revertir este proceso.

El colectivo artístico Critical Art Ensemble (CAE) desarrolló GenTerra, una instalación performativa abierta al público creada para explorar en vivo la variedad de discursos acerca de la transgénesis en relación con el riesgo ambiental y las políticas de salud humana.

Los espectadores que asistían a la muestra debían accionar una máquina robótica denominada Transgenic Bacteria Release Machine (Máquina de Liberación de Bacterias Transgénicas) que contenía diez cápsulas de petri sobre una plataforma circular. Una de las cápsulas presentaba en su interior un cultivo transgénico de la bacteria E. coli, las nueve restantes contenían muestras de moho y bacterias recolectadas de los alrededores de la exhibición. Los espectadores interactuaban con la máquina al presionar un botón que accionaba el giro de la plataforma circular que se detenía de manera aleatoria luego de unos segundos. Una vez que frenaba el movimiento, el brazo mecánico de la máquina bajaba y abría la cápsula de petri correspondiente. La posibilidad de abrir la cápsula que contenía el cultivo transgénico era de uno en diez, cuando un espectador la abría se encendía una luz roja a modo de alerta, en cambio, cuando abría alguna de las otras cápsulas que contenían las muestras de bacterias silvestres se encendía una luz verde.

Frente a la máquina cada espectador debía tomar una decisión: accionarla o no accionarla; participar en la propuesta artística y enfrentar la responsabilidad del resultado; calcular la probabilidad que tiene de que el medio ambiente se contamine a causa de su propia participación; o evitar participar [figuras 119 y 120]. Accionar la máquina significa tener la posibilidad de interferir en el ecosistema, es una decisión 
ética de cada espectador que debe comprender y evaluar los riesgos que implica liberar el cultivo de la bacteria transgénica.

La obra contemporánea suele exigir la participación del espectador, pero en estos casos esa interacción provoca serias consecuencias que deben ser evaluadas. Bajo una forma aparentemente lúdica dada a partir de máquinas, interfaces y sensores interactivos, las obras Late y Transgenic Bacteria Release Machine plantean diferentes problemáticas éticas que ubican al espectador en una disyuntiva ya que su participación implica convertirse en un intruso, una entidad infractora, entrometida y hasta inoportuna que pone en riesgo al medio ambiente y a los seres vivos que habitan en él.

\subsubsection{Espectador-protagonista}

Las obras que se centran en recrear un vínculo con el espectador generan una forma de producción artística netamente contemporánea que se traduce en distintos modos de encuentros "los meetings, las citas, las manifestaciones, los diferentes tipos de colaboración entre dos personas, los juegos, las fiestas, los lugares, en fin, el conjunto de los modos de encontrarse y crear relaciones representa hoy objetos estéticos susceptibles de ser estudiados como tales..."146

El acceso a la obra y a su temporalidad está sujeto a un acuerdo entre las partes, un horario que se estipula, una duración que se prevé, un tiempo que depende de la audiencia que convoca el artista. En suma, la obra que suscita encuentros y da citas administra su propia temporalidad ${ }^{147}$ pues la experiencia de la obra procesual y performativa se hace necesariamente en el tiempo.

\footnotetext{
${ }_{146}^{146}$ Bourriaud, N. Op. cit,. pp. 31-32.

${ }^{147}$ Ibid., p. 32.
} 
En el caso de aquellas obras procesuales, comportamentales o preformativas que requieren de una recepción individual, pautada y activa le asignan al espectador el lugar de protagonista, se concentran en su experiencia, en el intercambio, y en la dialéctica intersubjetiva del que observa y de aquello que lo mira. ${ }^{148}$

El 27 de marzo de 2008 la artista Tagny Duff envió un e-mail invitando a formar parte de la performance in-situ (in-vitro?) donde realizaría maniobras de laboratorio en el Instituto de Arte Contemporáneo de Perth (PICA), Australia. Al igual que el turno que uno solicita con el médico, para asistir al evento se debía pedir una cita con la artista, aquellos que deseaban participar debían reservar un lugar en el horario de 13 a 16 del día sábado 29 o domingo 30 de marzo. De esta manera, Duff agendó a los espectadores que asistirían y los recibió en el horario pautado ataviada con una bata descartable y guantes de látex sentada detrás de una mesa donde reposaban materiales de laboratorio.

La performance consistía en el simulacro de un análisis de HIV donde los supuestos donantes eran los espectadores citados. La artista sugería a cada espectador protegerse con batas y guantes de látex e invitaba a sentarse en el lugar asignado. Mientras se desarrollaba la performance Duff explicaba las técnicas y procedimientos científicos utilizados para saber si una persona tenía sida. Para ello desplegó sobre la mesa una serie de materiales traídos del laboratorio como pipetas Pasteur, placas para cultivo de seis pocillos, tubos para muestras de $50 \mathrm{ml}$, tubos para cultivo, tacho de basura con bolsas para desechos peligrosos, etc.

La obra se basaba en un test denominado "Elisa" que tiene la particularidad de no detectar el virus del HIV sino a los anticuerpos que produce el sistema inmunológico contra el virus. La prueba constaba de siete pasos, siete pequeños tubos con un

${ }^{148}$ Didi-Huberman, G. Op. cit., p. 38. 
líquido transparente que debían manipular los espectadores a partir de las indicaciones de la artista [figura 121]. En cada uno de estos pasos se debía colocar con una mini pipeta una gota del tubo indicado en un papel que simulaba ser una placa para cultivo [figura 122]. El primer tubo correspondía al antígeno, el segundo y tercero correspondían a los sueros de control positivo y negativo, el cuarto y el quinto eran las supuestas muestras de sangre de los donantes (un espectador asumía la posición del donante número uno y otro la del donante número dos), finalmente el sexto y el séptimo tubo contenían los sustratos fluorogénicos que revelaban si los donantes eran reactivos (positivos) o no reactivos (negativos) [figura 123].

El espectador no solo asistía a una cita programada con la artista para hablar sobre ciertos aspectos de la práctica de laboratorio, sino que se convertía en el protagonista principal al ser el donante (ficticio) de un test científico que se llevaba a cabo en el marco de una performance artística.

La obra Meart - The Semi-Living Artist (Meart - El Artista Semi-Vivo) ${ }^{149}$ explora la relación entre arte, ciencia y tecnología al utilizar un microchip llamado MEA ${ }^{150}$ [figura 124] para captar las ondas cerebrales que emiten las neuronas y traducirlas a un lenguaje visual. Desarrollada en los laboratorios de la UWA, el grupo de artistas, biólogos e ingenieros involucrados generaron un par de brazos robóticos que se movían de acuerdo a las órdenes dadas por la actividad de un cultivo neuronal para producir una serie de dibujos (garabatos) que posteriormente se convertirían en el retrato de uno de los espectadores.

\footnotetext{
149 Douglas J. Bakkum, Zenas C. Chao, Phil Gamblen, Guy Ben-Ary, y Steve M. Potter

150 MEA son las siglas de Multi-Electrode Array (cadena de electrodos múltiples). El nombre de la obra proviene del juego de palabras en inglés que forma el nombre del chip MEA y el agregado final de las letras $\mathrm{R}$ y $\mathrm{T}$ que en conjunto se traduce como "Mi arte".
} 
Para desarrollar esta obra debieron tener en cuenta tres aspectos importantes en la construcción del robot: la implementación de un software en el brazo robótico, el entrenamiento de los algoritmos del software para que promuevan las transformaciones senso-motoras en el brazo y la crianza del cerebro biológico [ver 回的].

En una primera instancia la obra llamada Fish and chips ${ }^{151}$ fue exhibida en Ars Electronica, Austria, con todos sus componentes emplazados allí. Se montaron dos cabinas estériles que funcionaban como laboratorios donde se cultivaba, alimentaba y regeneraba permanentemente el cultivo neuronal que emitía las señales para mover a las válvulas de relé que desplazaban los brazos robóticos. La estructura robótica se ubicaba por fuera de las cabinas sobre una tarima negra y disponía de tres fibras de colores que iban haciendo un dibujo en una hoja blanca [figura 125].

En una segunda instancia la obra fue expuesta de manera disociada, el "cerebro" del artista semi-vivo estaba ubicado en Atlanta en el Laboratorio de Neuro-Ingeniería del Instituto de Tecnología de Georgia, Estados Unidos, mientras que el "cuerpo" estaba en el Instituto de Arte Contemporáneo de Perth, Australia. El cerebro y el cuerpo interactuaban entre sí a través de una conexión a Internet en tiempo real generando un loop cerrado, una doble vía de comunicación que recogía y procesaba la actividad neuronal tanto en Perth como en Atlanta.

La novedad en esta instancia fue que el cultivo montado en un sustrato de vidrio (MEA) contaba con sesenta electrodos de lectura de la actividad neuronal que era estimulado por un único espectador cada día. La captura de una imagen fotográfica de ese espectador era descompuesta en sesenta pixeles en correspondencia con los

\footnotetext{
${ }^{151}$ El título es otro juego de palabra en inglés. En un principio la obra utilizaba neuronas de peces y chips electrónicos que leían la actividad neuronal. "Fish and chips" se debe a la utilización de estos elementos, pero también, es una alusión paródica al plato tradicional de comida inglesa. El nombre fue cambiado posteriormente por Meart ya que no utilizaron neuronas de peces ni las cultivaron en obleas de silicio.
} 
sesenta electrodos de estimulación neuronal. La información de la imagen del espectador viajaba por Internet de Perth hacia Atlanta para incentivar y estimular la actividad neuronal. La respuesta de la actividad llegaba cada cuatro segundos en forma de datos capaces de ser procesados por el microcontrolador que regulaba el compresor de aire de las válvulas de relé que movía los brazos robóticos. De esta forma, el visitante fotografiado se convertía en el protagonista del dibujo que realizaban los brazos durante toda la jornada; una suerte de retrato individual que luego era expuesto en las paredes de la sala [figuras 126 y 127].

Podemos señalar que in-situ (in-vitro?) y Meart - The Semi-Living Artist son dos obras muy diferentes. Una es una acción preformativa y la otra una instalación robótica, sin embargo tienen en común el lugar protagónico que se le asigna espectador, un rol indispensable para que la obra llevada a cabo adquiera en cada oportunidad un sentido diferente, único, e irrepetible como cada sujeto participante.

\subsubsection{Espectador-coproductor}

Desde los happenings y las performances de principios de los sesenta que deciden incluir al espectador en el entramado de la obra, hasta la incorporación de los nuevos medios y redes informáticas que definen el vínculo comunicacional con el usuario de manera interactiva, cada vez se le está dando más lugar al espectador en la producción y desarrollo de la obra de arte contemporáneo.

Lourdes Cilleruelo observa como el net.art estableció un cambio sustancial en la manera de producir y recepcionar la obra de arte al depositar en el espectador gran parte de la responsabilidad de la creación artística

El arte no es más un proceso individual, es un proceso interactivo que requiere de la participación en la obra y con los artistas. El espectador 
debe ahora tomar decisiones que antes eran privativas del autor, aproximándose las funciones de ambos. ${ }^{152}$

El rol del espectador contemporáneo debe asumir una posición más participativa (en contraposición al espectador moderno), y en ocasiones, trabajar conjuntamente con el artista en la producción de la obra. Razón por la cual Henry Jenkins ${ }^{153}$ utiliza el término "prosumidor" (acrónimo de productor y consumidor) para dar cuenta del lugar actual que enfrenta el espectador de los nuevos medios al involucrarse tanto con la producción como con la recepción de contenidos. Esta clase de espectador-productor está inmerso en una cultura participativa que contrasta con nociones más antiguas ligadas a un "espectador mediático pasivo" por lo que no es posible para Jenkins hablar de productores y consumidores como si desempeñaran roles separado, por el contrario se pueden ver como participantes que interaccionan entre sí de acuerdo a un nuevo conjunto de reglas.

El espectador-coproductor del bioarte colabora en el desarrollo de la obra a partir de las indicaciones que el artista le proporciona resultando una obra colectiva y conjunta dada en un entorno relacional, es decir, que el artista se preocupa más por el diálogo y la participación del espectador para conformar la obra que por otras cuestiones vinculadas a la autoría o a la huella del artista dejada en la producción de la obra.

Esto ocurre en Free Range Grain (Grano de campo) ${ }^{154}$ una obra del Critical Art Ensemble con Beatriz da Costa y Shyh-shiun Shyu que expone algunos principios de la ciencia y de las políticas corporativistas globales sobre la manipulación genética. Llevada a cabo en Austria, esta obra fue diseñada para concientizar al público europeo sobre las políticas económicas de la Unión Europea (UE) en relación a las

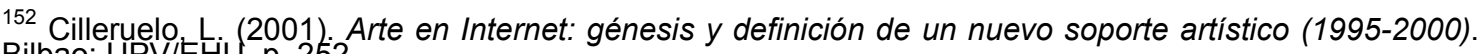
Bilbao: UPVIEHU, p. 252.

${ }^{153}$ Jenkins, H. (2008) Convergence culture. La cultura de la convergencia de los medios de comunicación. Barcelona: Paidós, p. 15.

${ }^{154}$ Free-range es un término que se utiliza en inglés para dar cuenta de la producción de cultivos o de animales que se desarrollan libremente, a campo abierto.
} 
regulaciones y los protocolos de prueba de la comida modificada genéticamente. Según describe el CAE, el primer objetivo de este proyecto artístico fue examinar la relación entre los límites y las materias primas en una economía global. La UE es entendida frecuentemente como una economía tanto abierta como cerrada, pero básicamente es una economía global. Debido a que productos como el trigo y la soja están siendo importados en grandes cantidades a Europa, el CAE desconfía de que la UE sea capaz de mantener los límites cerrados a las materias primas "contaminadas". El segundo objetivo era activar los procesos de desmitificación de la biotecnología por considerar que es un área plagada de mitos, fantasías, especulaciones erróneas y desinformación que conlleva a la mala interpretación de la producción científica.

De este modo, Free Range Grain hace partícipe al espectador que asiste a una acción performativa en vivo sobre los procesos rutinarios de la ciencia para que puedan verlos, practicarlos y comprenderlos de una forma más cercana. A través del montaje de un laboratorio portátil, los artistas invitan a los espectadores a traer alimentos que consideren sospechosos de ser manipulados genéticamente para ser testeados con pruebas de laboratorio. Luego de 72 horas de pruebas se puede corroborar si tales sospechas son justificadas [figuras 128 y 129].

La participación del espectador con el aporte de alimentos presumiblemente transgénicos y el testeo de los mismos permite lograr dos posibles resultados, que las pruebas indiquen que hay una gran probabilidad de que el alimento esté modificado genéticamente y eso permita llevar la discusión al ámbito público, o por el contrario, que no se encuentre ninguna alteración y eso dé credibilidad a las políticas alimentarias libre de contaminantes de la UE. En este sentido el espectador se involucra con la obra en todos los aspectos, desde la contribución del factor material con el aporte de alimentos hasta la posterior ejecución mediante pruebas de 
laboratorio y la reflexión final sobre los problemas éticos, políticos y de salubridad que provoca la modificación genética de comida.

Otro tipo de actividad que incluye al espectador en la producción conjunta de la obra son los denominados labworkshops o talleres laboratorio en donde los artistas brindan sus conocimientos teóricos y técnicos para la elaboración de productos biotecnológicos que pueden ser incluidos posteriormente en alguna exhibición artística. En el marco del ISEA 2006 (International Symposium on Electronic Art Simposio Internacional en Artes Electrónicas) se realizó Wetwarehackers (Aficionados a los componentes biológicos) una serie de talleres dictados por los artistas Beatriz da Costa, Oron Catts, Phil Ross, Paul Vanouse y Natalie Jeremijenko sobre la revolución biotecnológica en la industria farmacéutica, agraria y medicinal, y su impacto en la vida humana a partir de aspectos tales como la producción y consumo de alimentos modificados genéticamente, la reproducción animal y humana, los acuerdos comerciales mundiales, la preocupación medioambiental, la biodefensa, y la bioseguridad [figura 130]. Estas problemáticas emergen como consecuencia de las prácticas llevadas a cabo en laboratorios de biotecnología, lugares normalmente inaccesibles para el público general cuyos procedimientos con material biológico resultan ser la mayoría de las veces abstractos y opacos para el entendimiento del público aficionado. Por ello, Wetwarehackers propone una serie de talleres prácticos abiertos al público de ISEA para experimentar, jugar y explorar el potencial táctico de trabajar con componentes biológicos.

Beatriz da Costa en colaboración con los científicos Tau-Mu Yi y Christopher Kim propuso construir y probar un sensor de contaminación basado en el cultivo de levadura. Su workshop introducía a los participantes en las técnicas básicas de la 
biología sintética ${ }^{155}$ para construir un sensor de óxido nítrico en base a un cultivo de levadura al que introdujo un plásmido que contenía BFP (Blue Fluorescent Protein Proteína Fluorescente Azul) y que se activaba con la exposición al óxido nítrico otorgándole al cultivo un color azulado [figura 131]. Los resultados obtenidos de las prácticas de los participantes dieron lugar al año siguiente a la creación de la obra Experiments in Biosensing (Experimentos en Biosensado) en el que continuó desarrollando junto al público participante, a través de distintas performances y workshops, un sensor biológico experimental que captara la contaminación de dióxido de carbono del aire.

El colectivo artístico feminista subRosa combina arte, activismo y política para explorar y criticar los efectos de la biotecnología en el trabajo, la vida y los cuerpos de las mujeres. Mediante performances y workshops donde destacan el concepto DIY (Do-ityourself - Hágalo usted mismo) deciden enseñar a los espectadores los diversos aspectos de la biotecnología. En Epidermic! DIY Cell Lab (¡Epidérmico! Laboratorio Celular HUM) proponen realizar desde experimentos cotidianos como la preparación yogur hasta la visualización de procedimientos genéticos bacteriológicos y otros ligados a la clonación de células madre embrionarias y adultas [figura 132].

El workshop DIY Bodies Unlimited! ( Cuerpos ilimitados! HUM) consistió en un taller de ciencia amateur abierto al público general para la producción colectiva de conocimiento acerca de la biotecnología y el modo en que puede ser apropiada desde la práctica artística [figura 133]. En el taller los participantes aprendieron a manipular microscopios, cultivar bacterias en cápsulas de petri, extraer ADN de frutillas y mapear las huellas de la bioindustria en el entorno urbano con el fin de dialogar sobre biopoder y tácticas de resistencia. El registro de los distintos procedimientos desarrollados en el

\footnotetext{
${ }^{155}$ La biología sintética es una disciplina donde se investiga y trabaja en el diseño de sistemas biológicos moleculares artificiales que no existen en la naturaleza.
} 
laboratorio y las reflexiones generadas por parte de los participantes fueron exhibidos en el marco de la muestraSoft Power. Arte y tecnologías en la era del biopoder, promoviendo de este modo que las personas que participaron del workshop se convirtieran en los realizadores, coproductores junto a subRosa, de la muestra exhibida en la sala Rekalde de Bilbao [figura 134].

Hackteria es otro colectivo artístico internacional fundado en 2009 por el británico Andy Gracie, el suizo Marc Dusseiller y el hindú Yashas Shetty, cuya finalidad es la de desarrollar recursos para que el público pueda generar sus propias obras de bioarte. Para ello, suelen dictar seminarios y workshops por todo el mundo donde exponen sus conocimientos sobre biología DIY, open source (softwares de código abierto) y experimentación electrónica. Todos estos recursos son incluidos, además, en el sitio web hackteria.org donde es posible encontrar las instrucciones para realizar algunos de los siguientes elementos: DIY microscope, un microscopio basado en una cámara web; Pd_microscope, un programa de código abierto (aka Pure Data) que permite controlar el procesamiento gráfico del microscopio en tiempo real; DIY $\$ 25 \mathrm{Gel}$ Box, una manera económica y casera de realizar una matriz de gel para electroforesis; $D I Y$ handheld centrifuge y DIY tabletop centrifuge dos tipos de máquinas centrifugadoras que se utilizan para separar sólidos de líquidos de diferente densidad mediante una fuerza rotativa; DIY sterlisation hood, una cabina de esterilización en forma de caja transparente que mantiene el ambiente estéril dentro de ella; DIY incubator, una incubadora para el cultivo de bacterias; o GFP protocol Jugaad, el protocolo para realizar una bacteria transgénica que utiliza muchos de los dispositivos ya mencionados como la centrifugadora, la incubadora y la cabina de esterilización. 
La organización funciona como una comunidad que ofrece información, instrucción y reflexión crítica a través de reuniones, talleres y proyectos en curso en donde el público se involucra en primera persona con la práctica de bioarte.

Todos estos colectivos artísticos trabajan con los espectadores no sólo para desarrollar un objeto artístico sino también para abordar un concepto más general que refiere al conocimiento y concientización del campo biocientífico. De manera que artistas y espectadores colaboran y trabajan a la par persiguiendo un mismo objetivo.

Por lo expuesto, las características que asume el rol del espectador en el bioarte requiere reconsiderar su relación con la estética de la recepción. Según esta corriente el papel del receptor es decisivo en la obra. Así, ésta no puede ser comprendida prescindiendo de sus efectos, de modo que el análisis de la experiencia estética se centra en la conciencia que comprende y no en la obra en sí misma. Por lo tanto, y no sólo para el arte, la voluntad creadora es parcial e insuficiente para determinar el sentido de una obra por lo que resulta forzosa la conjunción con una instancia receptora.

Entre la intención y el efecto de una provocación, está en la vida política como en la historia de la ciencia, el imprevisible espacio de su recepción. El que una provocación tenga éxito, el que sirva de estímulo a un nuevo desarrollo o se incorpore a otras tendencias, o, por el contrario, se vaya disipando o caiga de nuevo en el olvido, es algo que no puede atribuirse solamente a su autor. ${ }^{156}$

Puesto que la obra no es nada sin su efecto, el sentido de un texto es producto de la convergencia entre el texto mismo y su recepción; la noción de obra alude al texto como estructura virtual que necesita ser concretada por la recepción del espectador.

\footnotetext{
156 Jauss, H. R. (1987). "El lector como instancia de una nueva literatura". En J. A. Mayoral (Comp.), Estética de la recepción. Madrid: Arco/libros, p. 60.
} 
Sin embargo, como señala Adolfo Sánchez Vázquez ${ }^{157}$, a partir de las manifestaciones artísticas de los años '60 la intervención del receptor no se vincula solamente con la interpretación, dotación de sentido o valoración de la obra, dimensiones abordadas por la estética de la recepción, sino también con su aspecto sensible, material. Puesto que el arte contemporáneo, sobre todo a partir de las nuevas tecnologías, amplía enormemente las posibilidades del espectador resulta necesario según Sánchez Vázquez desplazarse desde una estética de la recepción hacia una estética de la participación: "Estamos, por tanto, ante una participación del sujeto que no sólo afecta a la obra, o al proceso de su producción, sino también a él mismo en cuanto que se convierte en parte de la obra misma". ${ }^{158}$

Ligada a las transformaciones de la noción de obra y autor, se constata en el bioarte también una suerte de mutación de la categoría de espectador: de receptor a participante que se inserta en el proceso de creación o producción artística. Como se dijo, no sólo se trata entonces de visualización e interpretación por parte del espectador sino también de negociación e interacción con distintos grados de apertura: espectador-observador, espectador-testigo, espectador-invitado, espectadorintruso, espectador-protagonista y espectador-coproductor son las modalidades de inserción que hemos encontrado que el bioarte asigna al espectador. Al habilitar nuevos espacios de intercambio se constituyen diversos modelos de relaciones que tienen no sólo consecuencias estéticas. El extender la creación fuera del ámbito de los artistas, el ampliar los límites del conocimiento y concientización fuera del campo biocientífico también adquiere un valor social.

\footnotetext{
157 Sánchez Vázquez A. (2006). "De la estética de la recepción a la estética de la participación". En S. Marchan Fiz (Comp.), Real/virtual en la estética y la teoría de las artes. Barcelona: Paidós, pp. 17-28. ${ }^{158}$ Ibid., p. 25.
} 
6. BIOARTE COMO SÍNTESIS DE LA EXPERIENCIA 
Según el teórico Jean-Marie Schaeffer "una obra no puede jamás legitimarse estéticamente sino en su singularidad, para un receptor singular, en una experiencia singular. (...) Una relación viva con el arte sólo es posible en tanto, en ocasión de cada experiencia estética singular, la obra... se vuelve a poner en juego" ${ }^{\text {159 }}$. Esta noción de experiencia estética, central en la reflexión contemporánea sobre arte, como señala Jauss, es históricamente mutable, "desde siempre, el arte ha tenido, como función, la de descubrir o contraponer nuevas formas de experiencia en una realidad por sí cambiante". ${ }^{160}$ Sobre todo a partir de la modernidad se ha vinculado la experiencia estética con un sentimiento específico de placer tanto en el aspecto receptivo como en el productivo y se la ha contrapuesto a la experiencia entendida en un sentido epistemológico. Sin embargo, las transformaciones operadas por la tecnología en las formas de percepción han tenido su impacto sobre las características de la experiencia estética volviendo imprescindible una revisión de esta noción. En este punto, como veremos, el bioarte ha contribuido a poner en crisis las distinciones más o menos establecidas.

La Gran División moderna ${ }^{161}$ separa a la naturaleza de la sociedad de manera que, en un extremo se ubican los sujetos vinculados al mundo de los juegos del lenguaje mediante el cual construyen las reglas (racionales y universales) que rigen el campo de acción social y político; y en el otro extremo se encuentran los objetos, las cosas y

\footnotetext{
${ }^{159}$ Schaeffer, J. M. (2012). "La teoría especulativa del arte". Arte, objetos, ficción cuerpo. Cuatro ensayos sobre estética. Buenos Aires: Biblos, p. 45.

160 Jauss, H. R. (1986). Experiencia estética y hermeneútica literaria. Ensayos en el campo de la experiencia estética. Madrid: Taurus, p. 120.

${ }^{161}$ Latour, B. (1991/2007). Nunca fuimos modernos. Buenos Aires: Siglo XXI, p. 144 y ss.
} 
los animales, todo aquello que no es humano y que pertenece al mundo material y técnico de la naturaleza. Pero no es la única división establecida por los pensadores modernos, también separaron la esfera del arte de la esfera de la ciencia, y más aún, establecieron dos tipos de experiencias diferentes para cada una de estas.

René Descartes, al igual que otros pensadores de su época, deseaba lograr un saber cierto acerca del mundo revelado por la ciencia, por esto consideraba que la experiencia científica debía ser pública, reproducible y verificable mediante instrumentos objetivos. ${ }^{162}$ Abandona la concepción de conocimiento en términos de una realidad autorreveladora para dar lugar a un conocimiento científico representacional: conocer la realidad es poseer la representación correcta de las cosas a partir de las ideas que están dentro del sujeto. Para lograr ese conocimiento se debe desvincular al sujeto, separar el cuerpo del alma, con el fin de adoptar una postura crítica frente al cuerpo que lo objetive -lo vuelva objeto- y lo incluya en el mundo material para su comprensión.

El alma cartesiana no se libera obviando la experiencia, sino objetivando la experiencia encarnada. Se diría que el cuerpo es un objeto de inevitable atención para ella. Debe sostenerse en él para dar el salto que la liberará de él. ${ }^{163}$

El sujeto de la desvinculación y el control racional es una figura moderna, un modo de construirnos a nosotros mismos. Siguiendo la crítica heideggeriana a la modernidad, la desvinculación es siempre correlativa a la objetivación, en este sentido, objetivar significa neutralizar las normas y criterios que ejercen sobre el sujeto. La gran mecanización de la imagen científica del mundo a la que contribuyó Descartes en el siglo XVII fue una objetivación en este sentido. ${ }^{164}$

\footnotetext{
${ }^{162}$ Jay, M. (2009). Cantos de experiencia. Variaciones modernas sobre un tema universal. Buenos Aires: Paidós, p. 61.

${ }^{163}$ Taylor. C. Op. cit., p. 207.

${ }^{164}$ Ibid., p. 224.
} 
Locke toma de Descartes esta desvinculación del sujeto en tanto no es un modo de experiencia en primera persona sino que depende de una teoría objetivadora de la mente que proviene de su perspectiva mecanicista. La desvinculación exige dejar de vivir solamente en el cuerpo o en el seno de los hábitos y tradiciones para someterlos a un examen permanente que los convierta en objetos. ${ }^{165}$ Locke, con formación en fisiología, química y filosofía natural, “acompañó el surgimiento de la ciencia moderna como un modelo de experiencia 'en bruto' mejorada y corregida"166 en referencia a aquellas ciencias que se valían solo del razonamiento hipotético; en su ensayo De Arte Medica sostiene que una hipótesis que no pueda ser verificada experimentalmente no es una hipótesis válida. Desconfiaba tanto de las ideas innatas como del abuso de la razón deductiva y consideraba que el "método experimental" de Newton podía aplicarse a las ciencias naturales y también las ciencias morales.

El empirismo de Locke y Hume se basaba en el conocimiento sensible, por ejemplo, en la utilización del sentido de la vista para observar el objeto de estudio. Pero,
¿cómo podía el empirismo sostener su tesis de que el fundamento del saber probable o de la creencia razonable se hallaba en la observación cotidiana, cuando los objetos del saber científico eran cada vez más teóricos y contrarios a la intuición? Al ensancharse la brecha incluso entre las observaciones inferenciales y los objetos de la ciencia, generados teórica o matemáticamente, resultó cada vez más difícil recurrirá las impresiones sensoriales como la base para los criterios de verdad. ${ }^{167}$

En este marco surge la figura de Kant y su nueva teoría sobre el carácter trascendental de la experiencia cognitiva, que se enfoca menos en el objeto del conocimiento que en el sujeto "las entidades existen en el mundo, aun cuando no se las percibe; son objetos reales de los cuales es posible tener experiencia." ${ }^{168}$ Como

\footnotetext{
${ }^{165}$ ibid., p. 243.

166 Jay, M. Op. cit., p. 68.

${ }^{167}$ Ibid., p. 80.

${ }^{168}$ Ibid., p. 84.
} 
señala en la Crítica de la razón pura, la experiencia es el punto de partida del conocimiento humano.

En esta primera Crítica, Kant realiza una indagación trascendental (enfocando las condiciones de posibilidad del sujeto, la estructura a priori de la razón, que permiten la organización de la percepción sensible) para dar fundamento a la física así como para dar respuesta al problema sobre si la metafísica podría ser considerada una ciencia. En su siguiente obra Crítica de la razón práctica, elabora su teoría filosófica acerca de la ética y la moral en donde intenta hallar ciertos principios con el carácter de universalidad que posee la ciencia. Finalmente, en su tercera obra llamada Crítica del juicio establece las bases de la estética moderna al ocuparse del arte y el gusto. De este modo, Kant establece una clara diferencia entre lo concerniente a la ciencia, la moral y al arte. En la Crítica al juicio, el autor pone el acento en la facultad de juzgar, es decir, en la experiencia entendida según un modo más contemplativo y receptivo que creativo. Como se dijo en un capítulo anterior, Kant traslada la belleza asociada hasta ese momento a la obra hacia el sujeto como fuente del juicio estético, aquel que posee las facultades humanas para juzgar el gusto y experimentar el placer, por lo tanto, el placer de lo bello no se encontraría en el objeto sino en el juicio que produce el espectador, el artista o el crítico.

La estética kantiana fue tomada por los artistas románticos, especialmente por Schiller, para proclamar la soberanía del arte frente a los límites impuestos por la razón pura. La apreciación estética no tiene un fin utilitario ni un fin moral, el arte es "una finalidad $\sin$ un fin"169 afirma Kant, convirtiéndose así en el vehículo para trascender y superar la razón misma.

${ }^{169}$ Ibid., p. 173. 
Por su parte, en cuanto a la noción de experiencia, en las concepciones epistemológicas contemporáneas, sobre todo las distintas variaciones del positivismo -desde el positivismo lógico a Popper- subsiste una concepción de la experiencia reducida a experiencia científica.

Resulta de sumo interés examinar el bioarte a la luz de esta distinción que viene desde la modernidad entre, por un lado, la experiencia en un sentido epistemológico entendida como experimento científico, verificable y objetivo; y por el otro lado, la experiencia vinculada a lo subjetivo en cuanto capacidad del sujeto para experimentar el placer estético. En este sentido nuestra hipótesis es que el bioarte en tanto género artístico contemporáneo que se nutre de las investigaciones y desarrollos en biotecnología, concilia las dos concepciones de experiencia escindidas por la modernidad. El artista de bioarte, ya sea artista-científico, artista-investigador o artistadivulgador, manifiesta los dos tipos de experiencia al utilizar los experimentos científicos para producir su obra y al mismo tiempo superar los límites de la ciencia para celebrar la experiencia estética. Por consiguiente, la obra de bioarte ya no puede entenderse en el sentido moderno como un conjunto material, definido y estable que se exhibe en un museo, sino que plantea un entramado más complejo compuesto por el desarrollo de los experimentos de laboratorio, los registros parciales, las performances, las charlas divulgativas, etc. La obra de bioarte debería entenderse como un conglomerado de experiencias, es decir, la obra es la experiencia, es la capacidad de conjugar la experiencia artística y la experiencia en un sentido epistemológico.

Así, la obra de arte no es solo un objeto sino que da un giro hacia la centralidad de la experiencia: al entramado entre experiencia creadora, experiencia recreadora del espectador y experiencia del crítico. Según Martin Jay, el desplazamiento del arte 
desde el objeto hacia una experiencia más totalizadora es algo que viene ocurriendo en el arte desde las últimas décadas del siglo XX:

En casi todas esas obras -performativas antes que objetivadoras, efímeras antes que atemporales, enmarcadas en un contexto específico antes que descontextualizadas- el "aspecto cósico" del arte fue deliberadamente desechado. Si bien se abandonó a menudo la satisfacción desinteresada y se reemplazó la contemplación por la implicación kinestésica, el sujeto aún dominaba el objeto. La estimulación de experiencias cada vez más intensas en sujetos que reaccionaban con todos sus órganos sensoriales y no solo con el ojo contemplativo o con el oído desapasionado, pasó a ser la meta de buena parte del arte contemporáneo, cuyo crecimiento se fusionó con la industria del entretenimiento a la cual se había enfrentado antaño. ${ }^{170}$

A partir del bioarte, resulta interesante pensar que la ciencia ya no es algo opuesto al arte, ni se subordina uno al otro, sino que en este caso se complementan y tiene que suceder uno para que ocurra el otro; pues la obra en tanto experimento y experiencia ligada a la autorreflexión, la autocomprensión y el placer estético, intenta sintetizar dos formas de experiencia que desde la modernidad fueron separadas. También podría considerarse el bioarte como una autorreflexión científica y artística sobre los dispositivos técnicos, los alcances y posibilidades de la ciencia, sus potenciales peligros y su visión de la naturaleza como material explotable en el sentido heideggeriano de la técnica como lo propio del pensamiento contemporáneo y como una actitud hacia la naturaleza.

${ }^{170} /$ bid., p. 186. 
7. CONCLUSIONES 
En el marco de la crisis de legitimación del arte contemporáneo, hemos tratado de exponer los cuestionamientos que el bioarte introduce en la teoría estética tradicional. En este sentido, desarrollamos nuestra investigación en torno a la pregunta sobre si realmente el bioarte constituye una práctica novedosa, y en ese caso, si rompe con toda la tradición artística anterior al poner en crisis las categorías estéticas de obra de arte, artista, espectador y experiencia estética.

Teniendo en cuenta lo expuesto en esta tesis, podemos concluir que, como gran parte del arte contemporáneo, el bioarte plantea cuestionamientos referidos a la ontología del arte, esto es, interroga acerca de qué es lo que hace que algo pueda considerarse una manifestación artística y cómo distinguir al arte del no-arte. En este marco general, sostuvimos que el bioarte no establece una ruptura total con las categorías estéticas tradicionales, pero sí instaura desplazamientos y desestabilizaciones respecto de esas categorías.

I. En relación a la noción de obra de arte, se observó a) que se produce un quiebre con aspectos fundamentales de la obra moderna como su carácter material, local, continuo y permanente; b) pone en tensión los conceptos de colección, conservación y exhibición, de ahí que cuestiona a la propia institución museística y al mercado del arte; c) por su carácter híbrido pone en crisis todo intento por demarcar los límites de la propia obra así como de establecer distinciones disciplinares.

a) Uno de los rasgos esenciales de la obra de bioarte (teniendo en cuenta su filiación con el arte contemporáneo) es su no-disponibilidad. Por sus características orgánicas, 
la obra de bioarte es efímera, esto es, presenta una inestabilidad formal debido a sus condiciones biológicas. Como cualquier ser orgánico, las obras exigen un tiempo de gestación, desarrollo y deceso que varía de acuerdo a cada proyecto. Por otra parte, por la utilización de dispositivos contemporáneos como la instalación o las variantes de prácticas performativas (happenings, performances, meetings, etc.) que no están fijos ni son permanentes, se suelen establecer horarios, fijar citas y proponer lugares de encuentro para el acceso a la obra. En cambio, las pinturas y esculturas modernas se caracterizan por una constante disponibilidad debido a la perdurabilidad del material y a la posibilidad de acceder a través de muestras permanentes o colecciones estables. La obra de bioarte es a menudo no-disponible, se exhibe en un momento determinado y una vez que ello sucedió solo queda su documentación.

b) Estas características afectan también a los modos de circulación y exhibición, pues los espacios de exposición deben estar preparados para asistir a las obras de bioarte durante las 24 horas del día, atendiendo constantemente a sus necesidades orgánicas. Las instituciones deben ser conscientes de que no exhiben obras fijas e inalterables, por el contrario, presentan cambios, transformaciones, mutaciones y variaciones en sus dimensiones espaciales y en sus procesos temporales. En este sentido, Terry Smith sostiene que una institución que pretenda exhibir arte contemporáneo debe estar preparada para cualquier eventualidad que ocurriera, abriendo el espacio para todo tipo de eventos y dimensiones, y siendo capaz de enfrentarse con tiempos y espacios variables debido a su carácter efímero, móvil y procesual. También, como consecuencia de su fugacidad, las obras de bioarte se resisten a ser consideradas como mercancía. Este aspecto es fundamental pues pone en crisis los circuitos de circulación y acumulación propios del mercado del arte 
c) Otro aspecto problemático respecto del arte tradicional, es la cualidad híbrida de las obras de bioarte. La división establecida por concepciones modernas entre la esfera del arte y la esfera de la ciencia, y el tipo de experiencia que supusieron para cada una, supone una tensión con el bioarte por manifestar la combinación de ambas esferas y experiencias. Por dicha razón, ya no es tan evidente como en la modernidad conocer a priori las cualidades de una obra de arte, pues aquí las obras presentan una inestabilidad tanto formal (cambios de dimensión y duración) como discursiva (pertenencia al arte o la ciencia) dificultando así la especificidad de la actividad artística. Según Marc Jiménez, en los últimos años hubo una proliferación de trabajos que presentan una condición híbrida al ser al mismo tiempo obras de arte, investigaciones tecnológicas y experimentaciones científicas. Este aspecto es esencial pues constituye el carácter ambiguo y complejo de la obra de bioarte, al cual hacíamos referencia en la historia que diera apertura a esta tesis.

II. En relación al artista, mostramos que en el bioarte no es posible afirmar la desaparición de la figura del artista, pero sí desplazamientos y cierta inestabilidad sobre todo en cuanto a su función. Se trata de una figura híbrida que conjuga los saberes, la práctica y la experiencia científica con los saberes, la práctica y la experiencia artística. Por lo tanto, el bioarte confronta con las teorías modernas especialmente aquellas vinculadas al romanticismo- que conciben al autor como un genio creador, individual y subjetivo, que da forma a la inspiración mediante la configuración de una obra artística. Estas concepciones ubican al autor (el sujeto que crea) en un lugar central, a menudo por sobre la obra misma. El bioarte, como gran parte de la producción teórica y las manifestaciones artísticas a lo largo del siglo XX, pone en crisis la centralidad del artista. 
En ese contexto, determinamos figuras de artista en el bioarte a partir del análisis de la producción textual que refiere a los distintos autores y sus obras. De allí desprendimos tres figuras de artista que caracterizamos como: a) artista-científico, b) artistainvestigador y c) artista-divulgador.

a) Como ejemplos de artista-científico hemos visto a Joe Davis, Tagny Duff, Marta de Menezes y el colectivo TC\&A, quienes se involucran con las tareas de laboratorio para trabajar al mismo nivel que un científico especializado. Estos artistas han realizado distintas residencias de investigación en universidades, laboratorios y hospitales de todo el mundo con el objetivo de aprender las técnicas y los protocolos necesarios para producir por sí mismos cada una de sus obras. Inclusive, en algunos casos los métodos aprendidos son solo el puntapié inicial para realizar nuevas búsquedas e innovaciones en el campo científico a fin de aplicarlas al ámbito artístico.

b) Como artista-investigador hemos considerado a Eduardo Kac y el colectivo Proyecto Untitled, por indagar, analizar y conocer las diversas posibilidades que le brinda la ciencia pero no intervenir en la experimentación científica. Estos artistas tercerizan o transfieren el trabajo técnico de laboratorio necesario para desarrollar sus obras. Su relación con las tareas de laboratorio, en general, es para corroborar o dirigir la viabilidad de la obra.

c) Por último hemos ejemplificado el artista-divulgador con Joaquín Fargas, Steve Kurtz, Paul Vanouse y Daniel Alvarez Olmedo, por cumplir la función de acercar el conocimiento científico a un público no especializado utilizando diversos recursos y dispositivos del arte contemporáneo. Estos artistas dan a conocer aspectos científicos a los efectos de ayudar a popularizar los saberes herméticos de la ciencia para construir un vínculo simétrico con el espectador que desconoce esos saberes específicos. 
La figura de autor en el bioarte, como dijimos, es una figura híbrida que sintetiza los saberes, las prácticas y las experiencias científicas y artísticas. Es una figura múltiple que representa la interdisciplinariedad manifiesta en cada obra.

III. En cuanto al espectador, mostramos que en el bioarte participa activamente en el proceso de producción. Los dispositivos en que se presentan las obras como instalaciones, intervenciones, ambientaciones, eventos participativos y performances, requieren diversas demandas de negociación e intercambio por parte del espectador, en donde los grados de participación varían y también los modelos de relaciones sociales que asumen. En este marco establecimos que el rol del espectador oscila entre: a) observador, b) testigo, c) invitado, d) intruso, e) protagonista y f) coproductor de la obra.

a) El espectador-observador mantiene el rol más cercano al arte tradicional, pues plantea el menor grado de participación con la obra. No obstante, las competencias que el bioarte exige al espectador para comprender la complejidad de obras tales comolris Project de George Gessert, May the mice bite me if it is not true de Verena Kaminiarz, Move 36 de Eduardo Kac, Living Viral Tattoos de Tagny Duff o Ex-Sistencia de Allan Jeffs, dan cuenta de la problemática contemporánea sobre la interpretación y legibilidad de la obra de arte.

b) El espectador-testigo suele presenciar obras que responden a la categoría arte de acción. La performance es, ante todo, arte del tiempo, es un arte efímero que necesita materializarse de alguna manera para poder perpetuarse. Es por eso que la presencia del espectador no solo contribuye al reconocimiento y perdurabilidad de la obra a lo largo de la historia, sino que cumple un rol determinante al convertirse en testigo directo que autentica y da fe de la acción ocurrida. 
c) El espectador-invitado participa de la cultura de lo interactivo debido, principalmente, al desarrollo de las nuevas tecnologías de la comunicación y la imagen, pero también, por el deseo colectivo de crear otros espacios de sociabilidad e instaurar nuevos tipos de transacciones frente a la obra de arte. Las instalaciones digitales interactivas son las que posibilitan vincular al espectador con la obra mediante interfaces y dispositivos de entrada de datos. El espectador es invitado a participar, involucrarse y cooperar con la obra para su funcionamiento.

d) El espectador-intruso pone en juego un sistema de intercambio que tiene que ver con las decisiones que debe tomar en relación a la obra. En este caso, las obras se presentan como un lugar de cohabitación con el público donde se intenta probar el comportamiento del espectador que debe ser consciente del contexto en el que se encuentra y de la propuesta que puede implicar, desde provocar alguna catástrofe e interferir en el ciclo de vida de los organismos, hasta la desaparición misma de la obra. e) El espectador-protagonista suele participar en obras que se centran en recrear un vínculo único con el visitante a través de distintos modos de encuentros como meetings, citas, juegos, fiestas y lugares de reunión. La cita privada con Tagny Duff en in-situ (in-vitro?) o la asistencia a primera hora a Meart - The Semi-Living Artist, establecen un modo de encuentro particular al requerir una recepción individual, pautada y activa que le asigna al espectador el lugar de protagonista, se concentra en su experiencia, en el intercambio, y en construir una dialéctica intersubjetiva.

f) El espectador-coproductor asume una posición más activa y participativa al trabajar conjuntamente con el artista en la producción de la obra. Los artistas trabajan con los espectadores no sólo para desarrollar un objeto artístico sino también para dar a conocer y tomar conciencia, en este caso, de las implicancias de la biotecnología. De manera que artistas y espectadores colaboran y producen a la par persiguiendo un 
mismo objetivo en un entorno relacional, es decir, que el artista se preocupa más por el diálogo y la participación del espectador para conformar la obra que por otras cuestiones vinculadas a la autoría individual.

Así, al habilitar el bioarte nuevos espacios de intercambio se constituyen diversos modelos de relaciones que tienen no sólo consecuencias estéticas, también se amplían los límites de conocimiento, concientización y valor social. De esta manera nuestra concepción del rol del espectador en el bioarte se desplazó de una estética del espectador como intérprete activo a una estética del espectador como partícipe necesario en la concreción material de una obra. Por otra parte, ligado al carácter efímero de las manifestaciones de bioarte y la imposibilidad de que se conviertan en mercancía, desaparecerían en principio la figura del coleccionista y la del comprador o consumidor de arte.

Estos desplazamientos no pueden desligarse de los cambios promovidos por el arte contemporáneo que propiciaron la creación de obras con objetos que no tenían estatus de arte, dando lugar así a la indefinición de las propiedades constitutivas de una obra de arte, a la vez que rompían con la capacidad de previsibilidad del espectador. Este hecho abrió una distancia con el rol predecible, estático y de mera contemplación del espectador propuesto por la obra moderna, para pasar en la contemporaneidad a un espectador que ejerce un rol más activo, participativo y decisivo. A partir de las manifestaciones artísticas de los años '60, la intervención del espectador no se vincula solamente con la interpretación (dotación de sentido o valoración de la obra), sino también con su aspecto sensible y material. Puesto que el arte contemporáneo, sobre todo a partir del uso de las nuevas tecnologías, amplía enormemente las posibilidades del espectador resulta necesario desplazarse, como 
sostenía Sánchez Vázquez, desde una estética de la recepción hacia una estética de la participación.

En consecuencia, como mostramos, el bioarte no es ajeno a las transformaciones contemporáneas vinculadas a la noción de obra, autor, y también de espectador, al cual se le otorga la posibilidad de formar parte del proceso de creación o producción artística.

IV. En cuanto a la noción de experiencia, hemos visto como la modernidad separó la esfera del arte de la esfera de la ciencia, y estableció un tipo de experiencia diferente para cada una. En el caso de la ciencia, la experiencia es entendida como experimento científico, verificable y objetivo; y en el caso del arte, la experiencia está vinculada con un plano subjetivo, en cuanto capacidad del sujeto para experimentar ciertos sentimientos específicos como el placer estético.

El bioarte en tanto género artístico contemporáneo que se nutre de las investigaciones y desarrollos en biotecnología, concilia las dos concepciones de experiencia separadas por la modernidad: por una parte hace uso de los experimentos científicos, y por la otra, manifiesta la experiencia estética mediante la producción de obras de arte. En este sentido, la producción de bioarte debería entenderse como síntesis en tanto presenta la capacidad de conjugar tanto la experiencia artística como la experiencia científica.

En suma, en esta tesis se ha querido dar cuenta de la complejidad del bioarte como parte del escenario artístico contemporáneo, del que se desprenden una serie de problemáticas y discusiones específicas. Puesto que se trata de un campo de estudio en permanente transformación, exige que las categorías con las cuales se intenta reflexionar sobre él sean también dinámicas y sujetas a revisión constante. De ahí que 
esta investigación no cierra su tema de estudiosino que pretende más bien que futurasinvestigaciones encuentren en ella un punto de partida.

Finalmente resulta necesario señalar que el bioarte contribuye al pluralismo artístico contemporáneo y coexiste con manifestaciones modernas y tradicionales. Esta diversidad lejos de obstaculizar o socavar los alcances de las nuevas propuestas refuerza su originalidad a la vez que vuelve imprescindible la reflexión estética. 
8. BIBLIOGRAFÍA 


\section{BIBLIOGRAFÍA GENERAL}

SOBRE ESTÉTICA, TEORÍA E HISTORIA DEL ARTE

Argán, G. (1988/1991). El arte moderno. Del lluminismo a los movimientos contemporáneos. Madrid: Akal.

Bal, M. (enero 2006). "Conceptos viajeros en las humanidades”. Estudios Visuales, (3), 28-77.

Barthes, R. (1968/2009). "La muerte del autor" en El susurro del lenguaje. Barcelona: Paidós.

Benjamin, W. (1933/1982). Experiencia y pobreza. Madrid: Taurus.

Benjamin, W. (1936/1990). "La obra de arte en la época de su reproductibilidad técnica". Discursos interrumpidos I. Madrid: Taurus.

Bettetini, G. (1996). Las nuevas tecnologías de la comunicación. Buenos Aires: Paidós.

Bourriaud, N. (1998/2006). Estética relacional. Buenos Aires: Adriana Hidalgo.

Bozal, V. (ed.), (1996) Historia de las ideas estéticas y de las teorías contemporáneas, Madrid, Visor, (2 volúmenes).

Bürger, P. (1974/1997). "La obra de arte vanguardista". Teoría de la vanguardia. Barcelona: Península.

Cilleruelo, L. (2001). Arte en Internet: génesis y definición de un nuevo soporte artístico (1995-2000). Bilbao: UPV/EHU.

Correbo, M. N. "Algunas consideraciones sobre la figura del artista-científico". En Suárez Guerrini, F.; Gustavino, B.; Correbo, M. N. y Matewecki, N. Usos de la ciencia en el arte argentino contemporáneo. Buenos Aires: Papers.

Coulter-Smith, G. (2009). Deconstruyendo las instalaciones. Madrid: Brumaria.

Danto, A. (1997/2009). Después del fin del arte. Buenos Aires: Paidós.

Danto, A. (2002). La transfiguración del lugar común. Una filosofía del arte. Barcelona: Paidós.

De Lorenzo, J. (2010). "La noción de estilo en matemática y arte". En S. Castro y A. Marcos (Eds.), Arte y Ciencia: mundos convergentes. Madrid: Plaza y Valdés editores. 
Dery, M. (1998). Velocidad de escape. Madrid: Siruela.

Didi-Huberman, G. (1992/1997). Lo que vemos, lo que nos mira. Buenos Aires: Manantial.

Eco, U. (1962-1992). Obra Abierta. Buenos Aires: Editorial Planeta.

Foucault, M. (1998, abril). “¿Qué es un autor?”. Traducción: Silvio Mattoni. Título Original: Qu'est-ce qu'un auteur?. Conferencia en la Sociedad Francesa de Filosofía, publicada en el Bulletin de la S.F.P. julio-septiembre, 1969.

Foucault, M. (1978-1979/2008). Nacimiento de la biopolítica. Buenos Aires: FCE.

Galard, J. (1971/1973). Muerte de las bellas artes. Madrid: Fundamentos.

García Canclini, N. (2007, 1 de julio). "La Argentina tiene muchas zonas de fricción". Infobae.

Goldberg, R. (2002). Performance art. Barcelona: Destino.

Goodman, N. (1978/1990). Maneras de hacer mundos. Madrid: La balsa de la medusa. Huyssen, A. (1986/2002). Después de la gran división. Buenos Aires: Adriana Hidalgo. Ingarden, R. (1989). “Creación y reconstrucción”. En R. Warning (Ed.), Estética de la recepción. Madrid: Visor.

Jauss, H. R. (1986). Experiencia estética y hermeneútica literaria. Ensayos en el campo de la experiencia estética. Madrid: Taurus.

Jauss, H. R. (1987). "El lector como instancia de una nueva literatura". En J. A. Mayoral (Comp.), Estética de la recepción. Madrid: Arco/libros.

Jenkins, H. (2008). Convergence culture. La cultura de la convergencia de los medios de comunicación. Barcelona: Paidós.

Jiménez, M. (1999). ¿Qué es la estética? Barcelona: Idea Books.

Jiménez, M. (2005/2010). La querella del arte contemporáneo. Buenos Aires: Amorrortu.

Koldobsky, D. (2003). "La figura de artista cuando se anuncia su muerte", inédito.

Laddaga, R. (2010). Estética de laboratorio. Estrategias de las artes del presente. Buenos Aires: Adriana Hidalgo.

Latour, B. (1991/2007). Nunca fuimos modernos. Buenos Aires: Siglo XXI.

Lippard, L. (2011). "La desmaterialización del arte”. En R. Alonso (Curador), Sistemas, acciones y procesos 1965-1975. Buenos Aires: Fundación Proa.

Machado, A. (2006) "Convergencia y divergencia de los medios". Revista Miradas. La Habana: EICTV.

Manovich, L. (2007). "Understanding Hybrid Media". En http://www.manovich.net/DOCS/ae with artists.doc. Traducción: Eva Noriega y Melissa Mutchinick, FBA-UNLP.

Marchán Fiz, S. (1972/1997). Del arte objetual al arte del concepto. Madrid: Akal.

Maturana, H. y Varela, F. (1972/2003). De máquinas y seres vivos: autopoiesis, la organización de lo vivo. Buenos Aires: Lumen. 
Melamed A., (2014, agosto). "La pregunta por la técnica en el arte". IV Coloquio Internacional de Filosofía del Conocimiento, Facultad de Humanidades y Ciencias de la Educación, UNLP. La Plata, Argentina.

Melamed, A. (2010, noviembre). "La angustia entre creación e imitación: perspectivas contemporáneas sobre la teoría del genio". Revista figuraciones. Teoría y crítica de las artes, (7). Buenos Aires: Instituto Universitario Nacional del Arte.

Michaud, Y. (2007). El arte en estado gaseoso. Ensayo sobre el triunfo de la estética. México: Fondo de Cultura Económica.

Oliveras, E. (2006). Estética. La cuestión del arte. Buenos Aires: Ariel.

Oliveras, E. (2011). Cuestiones de arte contemporáneo. Hacia un nuevo espectador en el siglo XXI. Buenos Aires: Planeta.

Osborne, P. (2010). El arte más allá de la estética. Ensayos filosóficos sobre arte contemporáneo. Murcia: Cendeac.

Presas, M. (2001). "La recepción estética”. En D. Sobrevilla y J. Xirau (Ed.), Estética en Enciclopedia Iberoamericana de Filosofía. Madrid: Instituto de Investigaciones Filosóficas. Consejo Nacional de Investigaciones Científicas.

Rancière, J. (2008/2010). El espectador emancipado. Buenos Aires: Manantial.

Sánchez Vázquez A. (2006). "De la estética de la recepción a la estética de la participación". En S. Marchan Fiz (Comp.), Real/virtual en la estética y la teoría de las artes. Barcelona: Paidós.

Schaeffer, J. M. (2012). "La teoría especulativa del arte". Arte, objetos, ficción cuerpo. Cuatro ensayos sobre estética. Buenos Aires: Biblos.

Smith, T. (2009/2012). ¿Qué es el arte contemporáneo?. Buenos Aires: Siglo XXI.

Stallabras, J. (2004/2006). Contemporary Art. A very short introduction. New York: Oxford.

Vattimo, G. (1990). "Muerte o crepúsculo del arte". El fin de la modernidad. Nihilismo y hermeneútica en la cultura posmoderna. Barcelona: Gedisa.

Verón, E. (2013). "La autopoiésis productiva de la recepción". La semiosis social, 2. Buenos Aires: Paidós.

Wajcman, G. (1998/2001). El objeto del siglo. Buenos Aires: Amorrortu.

\section{FILOSOFÍA}

Agamben, G. (2002/2007). Lo abierto. El hombre y el animal. Buenos Aires: Adriana Hidalgo.

Ayer, A. (Ed.) (1965). El positivismo lógico. Madrid: FCE.

Bodei, R. (2006). Destinos personales. La era de la colonización de las conciencias. Buenos Aires: El cuenco de plata.

Bunge, M. (eds. vs.). La investigación científica. Barcelona: Ariel. 
Deleuze, G. y Guattari, F. (1991/1997). ¿Qué es la Filosofía? Barcelona: Anagrama.

Descartes, R. (1980). "Meditaciones Metafísicas". Descartes. Obras escogidas. Buenos Aires: Charcas.

Estiú, E. (1942/2010). "La fundamentación del mecanicismo en la física de Descartes". En J. C. Morán, Los filósofos y los días. Escritos sobre conocimiento, arte y sociedad. La Plata, De la Campana.

Gadamer, H.G. (1975/2003). Verdad y método. Salamanca: Ediciones Sígueme.

Habermas, J. (2008). El discurso filosófico de la modernidad. Buenos Aires: Katz.

Heidegger, M. (1935/2001). Introducción a la metafísica. Barcelona: Gedisa.

Heidegger, M. (1938/2000). Caminos del bosque. Madrid: Alianza.

Heidegger, M. (1954/1994). "La pregunta por la técnica". Conferencias y artículos. Barcelona: Ediciones del Serbal.

Hume, D. (1739/1974). Tratado de la naturaleza humana. Buenos Aires: Paidós.

Jay, M. (2009). Cantos de experiencia. Variaciones modernas sobre un tema universal. Buenos Aires: Paidós.

Kant, I. (1787/1972). Crítica de la Razón Pura. México, Porrúa.

Kant, I. (1790/1973). Crítica del Juicio. México: Porrúa.

Khun, T. (1962/2004). La estructura de las revoluciones científicas. Buenos Aires: FCE.

Morán, J. (Comp.) (2006/2008). Por el camino de la filosofía. Pensar de nuevo la modernidad. La Plata: De la campana.

Popper, K. (1979). "Tres concepciones sobre el conocimiento científico". El desarrollo del conocimiento científico. Conjeturas y refutaciones. Buenos Aires: Paidós.

Ricoeur, P. (1965/1970). Freud: una interpretación de la cultura. México: Siglo XXI.

Taylor, C. (1989/2006). Fuentes del yo. Barcelona: Paidós.

\section{OTROS}

Alzogaray, R. (2004). Una tumba para los Romanov. $Y$ otras historias con ADN. Buenos Aires: Siglo XXI.

Argibay, P. (2007). Cortar y pegar. Trasplantes de órganos y reconstrucción del cuerpo humano. Buenos Aires: Siglo XXI.

Díaz, A. (2005). Bio... ¿Qué? Biotecnología, el futuro llegó hace rato. Buenos Aires: Siglo XXI.

Díaz, A. y Golombek, D. (Comps.) (2007). ADN cincuenta años no es nada. Buenos Aires: Siglo XXI. 
Rossi, S. y Levin, L. (2006). Qué es (y qué no es) la Evolución. Buenos Aires: Siglo $\mathrm{XXI}$.

Vestfried, M. (1988). Filosofía Biológica. Buenos Aires: Celcius.

\section{BIBLIOGRAFÍA ESPECÍFICA SOBRE BIOARTE}

\section{LIBROS}

Bulatov, D. (Ed.) (2004). BioMediale. Contemporary Society and Genome Culture. Russia: The National Center for Contemporary Arts/The National Publishing House.

Critical Art Ensemble (2002). The Molecular Invasion el Critical Art Ensemble. New York: Autonomedia.

Critical Art Ensemble. (2006). Marching Plague: Germ Warfare \& Global Public Health. New York: Autonomedia.

Fonts da Costa, P. (Coord.) (2007). Ciência e bioarte. Encruzilhadas e daseafios éticos. Portugal: Caledoscópio.

Kac, E. (2005). Telepresence and Bio Art. Michigan: University of Michigan Press.

Kac, E. (Ed.) (2007). Signs of life. Bioart and beyond. London: MIT Press.

Leopoldseder, H.; Schöpf, C. y Stocker, G. (2007). CyberArts 2007. International compedium - Prix Ars Electronica 2007. Áustria: Catje Cantz.

Mitchell, R. (2010). Bioart and the vitality of the media. Seattle: University of Washington Press.

Schöpf, C. y Stocker, G. (2005). Hybrid, living in paradox. Austria: Hatje Cantz.

Wilson, S. (2002). Information Arts. Intersections of Art, Science, and Technology. Londres: MIT Press.

\section{CAPÍTULOS DE LIBROS}

Hauser, J. (2005). "Bio Art - Taxonomy of an etymological monster". En C. Schöpf y G. Stocker (Eds.), Hybrid, living in paradox. Austria: Hatje Cantz.

Kac, E. (2007). “Introduction”.En E. Kac (Ed.), Signs of life. Bioart and beyond. London: MIT Press. 
Matewecki, N. (2012). "Cuerpos híbridos: cuerpos biónicos, cuerpos semi-vivos, cuerpos manipulados". En A. Ceriani (Comp.), Arte del cuerpo digital. Nuevas tecnologías y estéticas contemporáneas. La Plata: Edulp.

Davis, J. (2004). "Monsters, maps, signals and codes". En D. Bulatov, D. (Ed.), BioMediale. Contemporary Society and Genome Culture. Russia: The National Center for Contemporary Arts/The National Publishing House.

Gessert, G. (2004). "A History of Art involving DNA". En D. Bulatov, D. (Ed.), BioMediale. Contemporary Society and Genome Culture. Russia: The National Center for Contemporary Arts/The National Publishing House.

Kac, E. (2004). “El Octavo Día”. En Mungi, A., Elorza, C. y Billabeitia, I. (Eds.),Arte y pensamientos en la era tecnológica. Bilbao: Universidad del País Vasco.

Marchal, H. (2005) "El anfitrión de la casa del hombre". En E. Rossi (Ed.), Eduardo Kac: Move 36. Paris: Filigranes Éditions.

ARTí́CULOS

Alemian, E. (2012, 20 de noviembre). "Cuando el arte y la tecnología se encuentran". Revista $\quad \tilde{N}$. http://www.revistaenie.clarin.com/ideas/Claudia-Kozak-artetecnologia 0 812318779.html

Ali-brouchoud, F. (2006, 9 de abril). "Acerca de la biología del arte".Página 12. http://www.pagina12.com.ar/diario/suplementos/espectaculos/6-2006-0409.html.

Anker, S. (1994, Mayo). "Creativity and the Retro-Virus". M/E/A/N/I/N/G. http://www.geneculture.org/essays.html.

Beiguelman, G. (2001, 27 de noviembre). "A coelhinha e a bioarte". Trópico.http://p.php.uol.com.br/tropico/html/textos/427,1.shl.

Benítez, L. (2009, primavera). "Bioarte. La vida como material". Disturbis (5). http://www.disturbis.esteticauab.org/Disturbis567/LBenitez.html

Bevis, S. (2007, 8 de septiembre). "High-tech artistry put to BEAP test". West Weekend Magazine.

Bloch, A. (2006, 4 de abril). "Arte é tudo. É?".O Globo, Segundo Caderno.http://www.canalcontemporaneo.art.br/tecnopoliticas/archives/000069. html.

Careaga, M. (2013, 30 de octubre). "Bioarte, el impulso cultural de la ciencia". Cultura colectiva. http://culturacolectiva.com/bioarte-el-impulso-cultural-de-la-ciencia

Catts, O. y Zurr, I. (2003). "The ethical claims of Bio Art: killing the other or selfcannibalism?". The Australian and New Zealand Journal of Art,(4), 167188.http://www.tca.uwa.edu.au/publication/TheEthicalClaimsofBioart.pdf.

Catts, O.; Kac, E. y Zurr, I. (2005, enero). "Artists againts PETA". En B. Lafargue (Comp.), Figures de l'art 8: Animaux d'artistes, Pau: PUP. 
Catts, O. y Zurr, I. (2006, noviembre). "Hacia una nueva clase de ser. El cuerpo extendido". Artnodes, (6), 3-12.

Coakley, J. (2004). "Welcome to the World of BioArt". The Space ABC Arts on line.http://www.abc.net.au/arts/digital/stories/s877305.htm.

Costa, F. (2008, 1 de noviembre). "Bioarte made in Argentina". Revista N.

Daubner, E. (2005, 8 de abril). "Stranger than Fiction: Biotech XX Artists Manipulate Life. DPI: la revue électronique du Studio $X X$, (3). http://dpi.studioxx.org/index.php?id=56.

Debatty, R. (2007, diciembre). "Genetically modified art”. Art Review, (17), 108.

De menezes, M. (2003). "The Artificial Natural: Manipulating Butterfly Wing Patterns for Artistic Purposes".Leonardo, vol. 36, (1), 29-32. http://www.martademenezes.com/leonardo.pdf.

Día López, I. (2014, 15 de mayo). "Luis Guzmán: 'El bioarte es una categoría que permite ser deconstruida'”. Facultad de Artes de Chile.http://www.artes.uchile.cl/noticias/101315/luis-guzman-el-bioarte-es-unacategoria-que-permite-ser-deconstruida.

Espinosa Vera, C. H. (2006, julio). "Eduardo Kac: en realidad, todos somos transgénicos". Escáner cultural, año 8, (85).

Ferdinand, P. (2001, diciembre). "Art and Science: at MIT, Science Gives New Life to Art". Washington Post.

Fernández, D. (2011, 27 de marzo). "Por las sendas de Da Vinci". La Nación. http://www.lanacion.com.ar/1360532-por-la-senda-de-da-vinci.

Fitzgerald, M. (2004, 23 de agosto). "Giving (real) life to art. Genetics and tissue culture find new forms -and a new audience". Time, 66-67.

Fraser, J. L. (2007, 11 de septiembre). "Borders and boundaries". CMAJ, 177, (6), 609610.

Galindo, D. (2005, 21 de julio). "Arte \& controle de materiais biológicos no Brasil: vale a pena dialogar?".Canal contemporâneo. http://www.canalcontemporaneo.art.br/tecnopoliticas/archives/000474.html.

García, F. (2006, 26 de marzo). "Eduardo Kac: El arte imposible de hoy es la banalidad de mañana".Clarín.http://www.clarin.com/diario/2006/03/26/sociedad/s04901.htm.

Gemin, T. (2005, diciembre-2006, enero). "Bioart, tra etica ed estetica".DigiMag (10).http://www. digicult.it/digimag/article.asp?id=283.

Gessert, G. (2004, marzo-abril). "An Introduction to Genetic Art".Gene Watch,vol. 17, (2).http://www.ekac.org/gessert council.html.

Gibbs, W. (2001, 17 de abril). Entrevista a Joe Davis: "Art as a form of life". Scientific American Magazine. http://www.scientificamerican.com/article.cfm?id=art-as-aform-of-life.

Goldsteind, M. (2007, 25 de octubre). "Bio curious. It's alive! A new art exhibiton redefines weird science". 7x7 Magazine. 
Gomart, E. (2007). "Parallels of Science and art: on the Show Genesis". Simulacrum, vol 15, (3/4), 8-11.

Guarino, J. (2006, 15 de diciembre). "Vivir con un chip, la nueva manía del arte contemporáneo". Clarín. http://old.clarin.com/diario/2006/12/15/sociedad/s05701.htm

Kac, E. (1998, diciembre). "Transgenic Art". Leonardo Electronic Almanac,vol. 6,(11).

Kac, E. (2004, 14 de diciembre). "A polêmica da bio-arte em entrevista com Eduardo Kac". Portal Sesc SP.http://www.ekac.org/sesc.2004.html.

Hax, A. (2006, 1 de julio). "Lo último: tener en el living un retrato abstracto del ADN". Clarín. http://www.clarin.com/diario/2006/07/01/sociedad/s-05801.htm.

Longley, G. (2007, 8 de septiembre). "face2face Orlan”. West Weekend Magazine, 810.

López del Rincón, D. (2013). "Rematerialized Tendencies in Media Art? From Silicon to Carbonbased Art".Sociología y tecnociencia/Sociology and Technoscience, vol 1, (3), 32-56.

López del Rincón, D. y Cirlot, L. (2013, noviembre). "Historiando el bioarte o los retos metodológicos de la Historia del Arte (de los medios)". Artnodes, (13), 62-71.

Macmasters, M. (2006, 29 de mayo). "Llega a México Eduardo Kac, creador de organismos transgénicos como obras".La Jornada. http://www.jornada.unam.mx/2006/05/29/index.php?section=cultura\&article=a0 $\underline{6 n 1 \mathrm{cul}}$.

Manzini, P. (2006, 30 de marzo). "Eduardo Kac en Buenos Aires".Educ.ar.http://portal.educ.ar/debates/protagonistas/arte-cultura/eduardokac-en-buenos-aires.php.

Marinaro, A. (2013, 27 de junio). "El encanto del bioarte". Revista N.

Matewecki, N. (2007). “Arte genético / Arte transgénico. ¿Arte o Ciencia?”. B, año 1, (1), 117-121.

Matewecki, N. (2009). Aproximaciones al Bioarte: concepto - cuerpo - género (tesis de magíster). Facultad de Bellas Artes, Universidad Nacional de La Plata, La Plata, Argentina.

Medina, E. (2007, 10 de enero). "Bioarte: una nueva fórmula de expresión artística".Revista Digital Universitaria, vol. (1).http://www.revista.unam.mx/vol.8/num1/art01/ene art01.pdf.

Moura, L. (2005, Junio). "Bioarte: uma nova forma de arte". http://www.Ixxl.pt/artsbot/text02.html.

Nestelbacher, R y Stocker, G. (2007). "GFPixel- the digital life”. A minima, (20).

Páez, N. (2008, 20 de diciembre). "'Fitotrón', el invento argentino que anticipó la moda del Bio-arte". Revista N.

Pagliarini, L.; Locardi, C. y Vucic, V. (2000, primavera). "Toward Alive Art". Virtual Worlds. Paris: Proceedings.Traducido por Prof. Bernardo Uribe Mendoza, http://www.adaptronics.dk/Publications/html/ArteViviente.html. 
Palmiéri, C. (2005, junio-agosto). "Entrevue avec Eduardo Kac. L’Ėre biotech. La vie augmentée". ETC, Revue de l'art actuel. Débat et critique, (70), 33-39.

Pasko, J. (2007, 4 de marzo). "Bio-artists bridge gap between arts, sciences". MSNBC. http://www.msnbc.msn.com/id/17387568.

Pentecost, C. (2007). "Cuando el arte deviene vida. Artistas investigadoras y biotecnología". Instituto Europeo para Políticas Culturales Progresivas.http://eipcp.net/transversal/0507/pentecost/es

Pérez Bergliaffa, M. (2012, 14 de diciembre). "Artistas de laboratorio". Revista N. http://www.revistaenie.clarin.com/arte/Artistas-laboratorio-arte-cienciauniversidad-maimonides 0 824917550.html

Rees, J. (2008, 21 de febrero). "Cultures in the capital". Nature, vol 451, 891.

Refi, P. (2007, 9 de diciembre). "Bioarte: del laboratorio a la galería”. DiarioHoy.

Reyes, A. (2000). "La artista que rediseña mariposas". URL, 3.12.

Sáez, C. (2007, enero). "Llega el bioarte. Lienzos en la probeta". Muy interesante, (308), 52-56.

S/D (2004, 28 de febrero). "Art, but not as we know it". New Scientist, (2436), 44-47. http://www.newscientist.com/article/mg18124365.400-art-but-not-as-we-knowit.html

S/D (2004, mayo). "Arte biotecnológico. Los arcanos de un arte mutante". RTD Info. http://ec.europa.eu/research/rtdinfo/special as/article 814 es.html.

S/D (2005, 28 de septiembre). "Bioarte: revela obras inspiradas na ciência e biologia". Ciberiahttp://ciberia.aeiou.pt/gen.pl?p=stories\&op=view\&fokey=id.stories/3507\& sid=id.sections $/ 32$.

S/D (2011, 21 de agosto). "La metamorfosis". Suplemento Radar, Página 12.

S/D (2014, 5 de junio). "Reconstruyendo la oreja 'real' de van Gogh". Clarín.http://www.clarin.com/sociedad/oreja-Van Goghbioarte 0 1151285246.html

Sarno, A. y Grosso, D. (2006, verano). "Questa è...Bioarte". Overview, año 1, (5).http://www.undo.net/cgi-bin/openframe.pl?x=/cgibin/undo/magazines/magazines.pl\%3Fid\%3D1152090466\%26riv\%3Doverview \%26home\%3D.

Schlipalius, M. (2005). "Pensei que isto era uma Galeria de Arte. Experiências do Público em Bioarte". Nada, (5).

Schwartz, J. (2008, 13 de mayo). "Museum Kills Live Exhibit". TheNew York Times. http://www.nytimes.com/2008/05/13/science/13coat.html? $\quad \mathrm{r}=0$

Slavin, M. (2007, 6 de abril). "The art of science". Haaretz magazine, 22-24.

Solon, O. (2011, 28 de Julio). "Bioart: The Ethics and Aesthetics of Using Living Tissue as a Medium". Wired. http://www.wired.com/2011/07/bioart.

Steinmetz, M. (2003, abril). "Ces artistas cultivent le vivant". Regards, (89).

Thacker, E. (2004, 4 de Agosto). "Three lessons on Pop Biotech". Gene Watch, vol 17, (4), 3-5.http://www.gene-watch.org/genewatch/articles/17-4Thacker.pdf. 
Ter Gaast, E. (2007). "Genpets ${ }^{\mathrm{TM}}$ and the Transgenic Rabbit". Simulacrum, vol 15, (3/4), 25-27.

Van Rijk, D. (2007). "Where art and life meet". Simulacrum, vol 15, (3/4), 31-35.

Van Rijsingen, M. (2007). "Science and art". Simulacrum, vol 15, (3/4), 3-7.

Versa, V.(2007, 30 de octubre). Entrevista a Natalia Matewecki: "En la UNLP investigan el avance del arte transgénico". Diario Hoy.

Versa, V. (2009, 15 de febrero). Entrevista a Natalia Matewecki: "Una visita al bioarte, donde las obras utilizan la manipulación genética". DiarioHoy.

Verspaget, C (2006). "Arte y Biología". A mínima, (18).

Vicente, J. L. (2001, 10 de septiembre). "Eduardo Kac, artista electrónico, el creador de seres imposibles". Diario El Mundo. http://www.temakel.com/embioarte.htm.

Waelder, P. (2013, 19 de marzo). "Entrevista a Paul Vanouse". Fundación Telefónica. Disponible en http://vida.fundaciontelefonica.com/blog/entrevista-a-paulvanouse

Walden, S. (2013, 29 de octubre). "BioArt: Is It Art? Is It Science? Is It the Future?". Mashable. http://mashable.com/2013/10/29/cutpastegrow-bioart.

Willet, J. y Bailey, S. (2007). "Bioteknica: Teratologías". A minima,(20), 6-13.

Zaretsky, A. (2007). "Becoming wild can mean”. Simulacrum, vol 15, (3/4), 37.

\section{CATÁlOgOS}

De menezes, M. (2000). "Nature". EnCatálogo de Ars Electronica 2000, Next Sex. Linz, Austria.http://www.martademenezes.com/Nature.pdf.

Hauser, J. (Ed.) (2003).Catálogo L'ArtBiotech.Le Lieu Unique. Nantes, Francia.

Hauser, J. (Comp.) (2008). CatálogoSk-interfaces: Exploring Borders-Creating Membranes in Art, Technology and Society. Cambridge, Inglaterra.

Proyecto Untitled. (2013). Catálogo Proyecto Untitled. Arte, ciencia y tecnología. Buenos Aires, Argentina.

Thomas, P. (2002). Catálogo Biennale of Electronic Arts Perth (BEAP), Locus. Perth, Australia.

Thomas, P. (2004). Catálogo Biennale of Electronic Arts Perth (BEAP), Same Difference. Perth, Australia.

Thomas, P. (2007). Catálogo Biennale of Electronic Arts Perth (BEAP), Stillness. Perth, Australia. 
9. ANEXO 
REFERENCIAS DE LAS IMÁGENES

[figura 1] Imagen impresa en este anexo.

[ver 回象] Video incluido en el CD.

[ver Orlan antecedentes] Imágenes extras incluidas en el CD. 
Figura 1
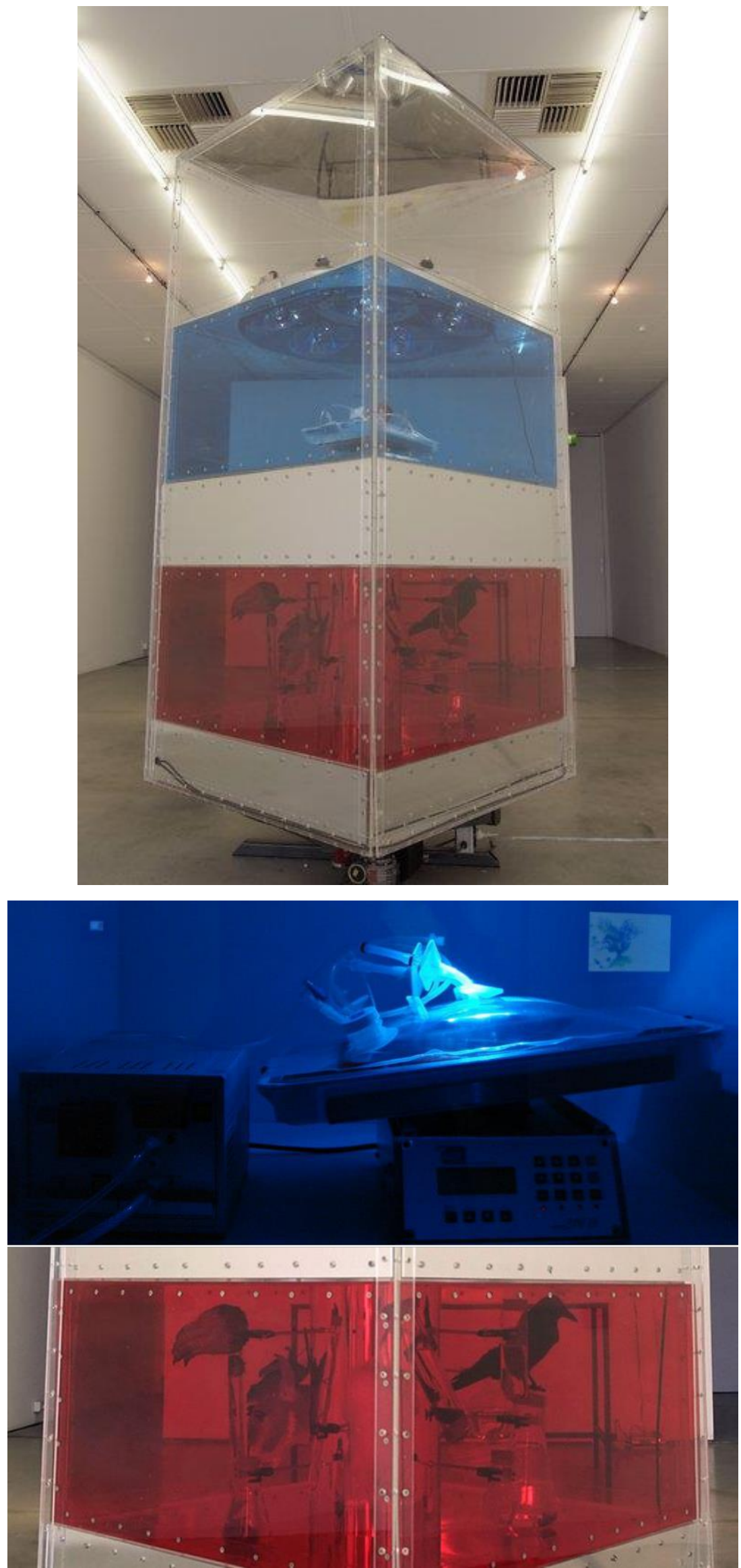

Tissue Culture \& Art Project, "NoArk". Muestra Stillness, BEAP 2007, Perth, Australia, 2007. () TC\&A

Tissue Culture \& Art Project, "NoArk". Detalle del

biorreactor (arriba) y de los animales disecados (abajo) (c) TC\&A 
Figura 3
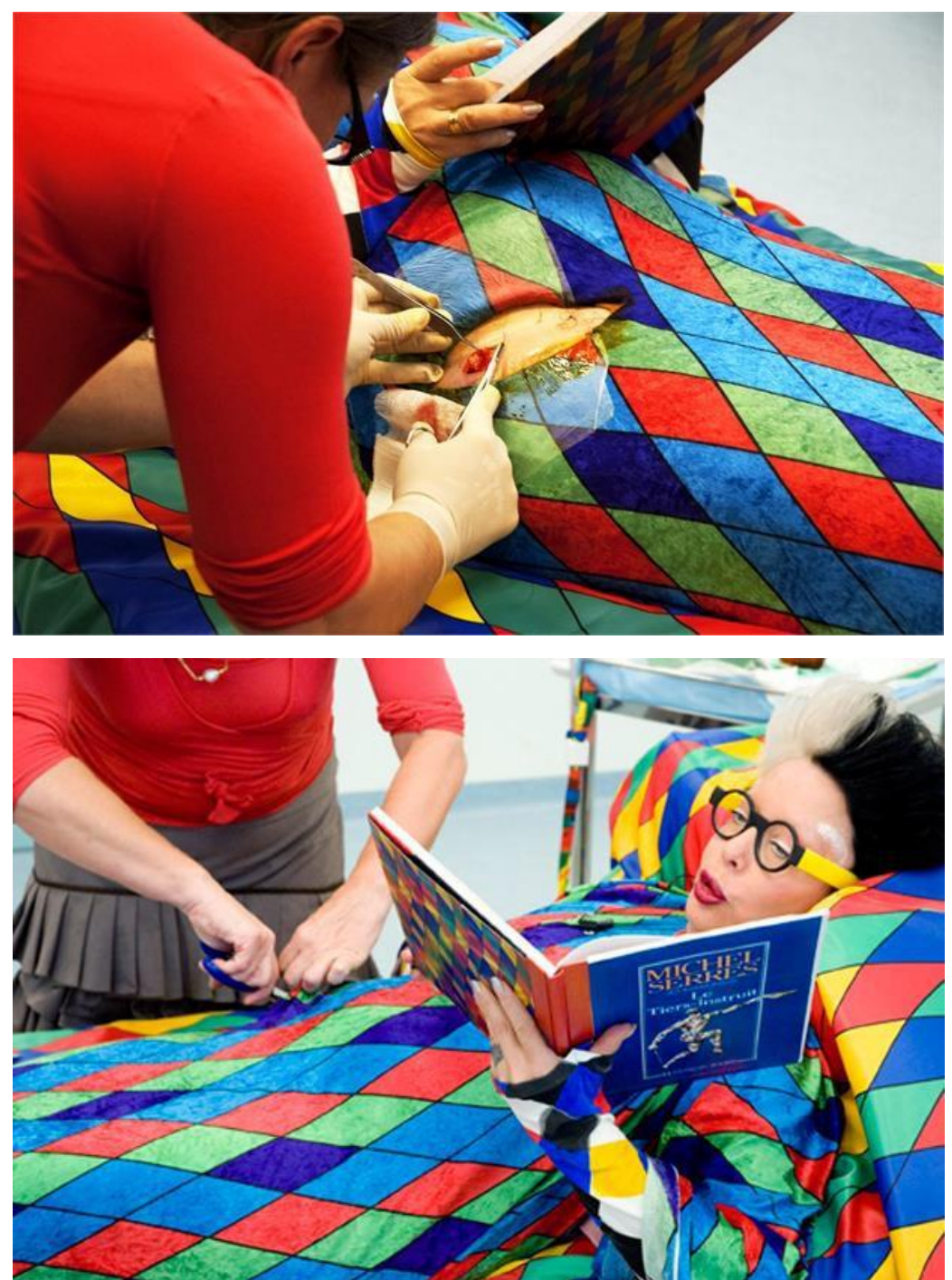

Figura 4

Figura 5

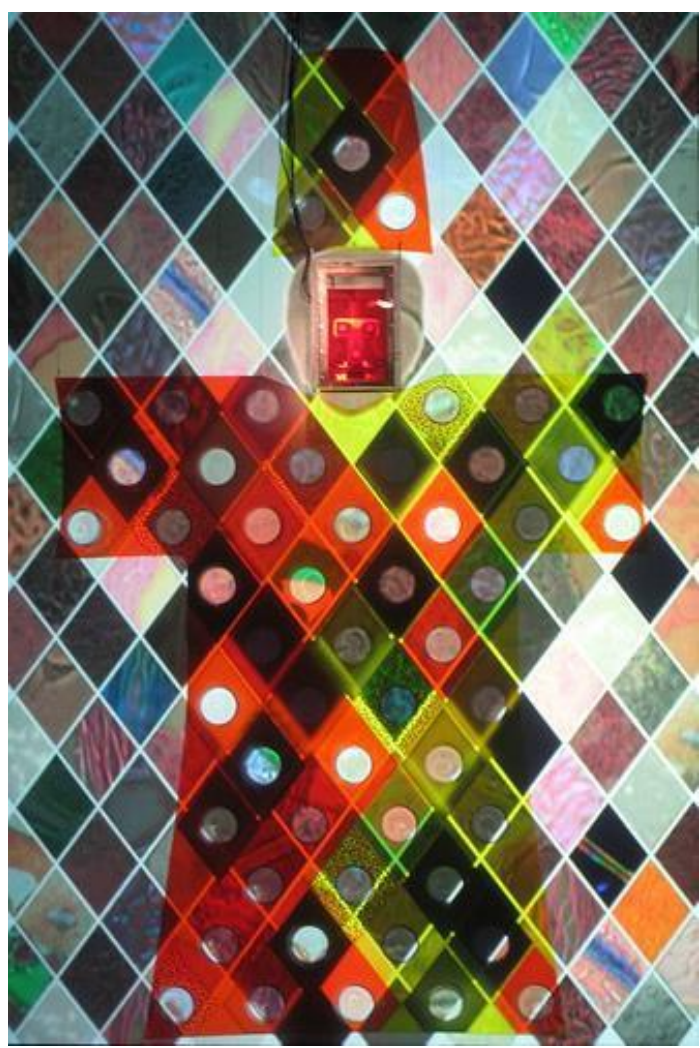

Orlan, "Harlequin Coat". Extracción de células epiteliales de la artista. ANHB - UWA, Perth, Australia, 2007. ( ) Orlan, fotografía de Tony Nathan

Orlan, "Harlequin Coat". Imagen de la artista leyendo el texto Laïcité de Michel Serres mientras se somete a una biopsia. ANHB - UWA

Perth, Australia, 2007. (c) Orlan, fotografía de Tony Nathan
Orlan, "Harlequin Coat". Parte de la instalación en la muestra sk-interfaces. FACT, Liverpool, Inglaterra, 2008. (C) Orlan, fotografía original de Tony Nathan 
Figura 6

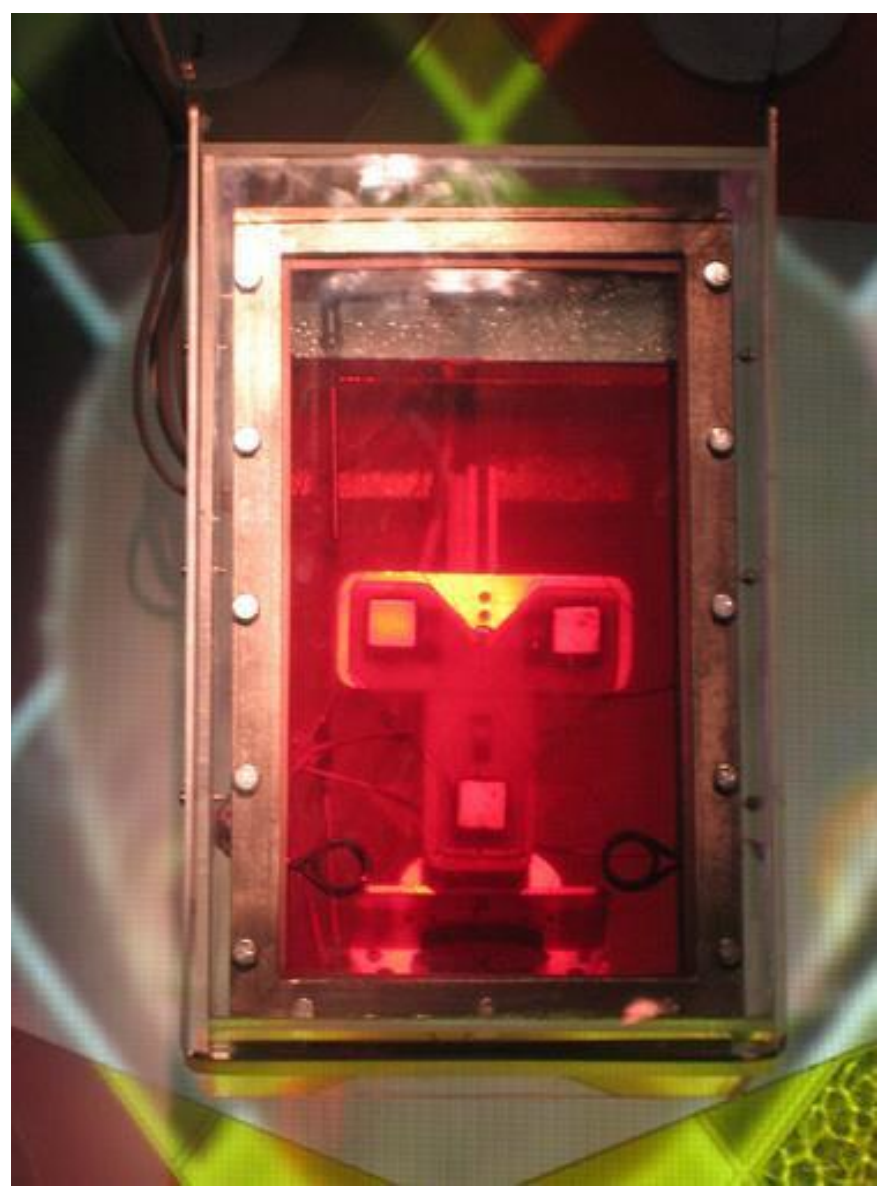

Figura 7

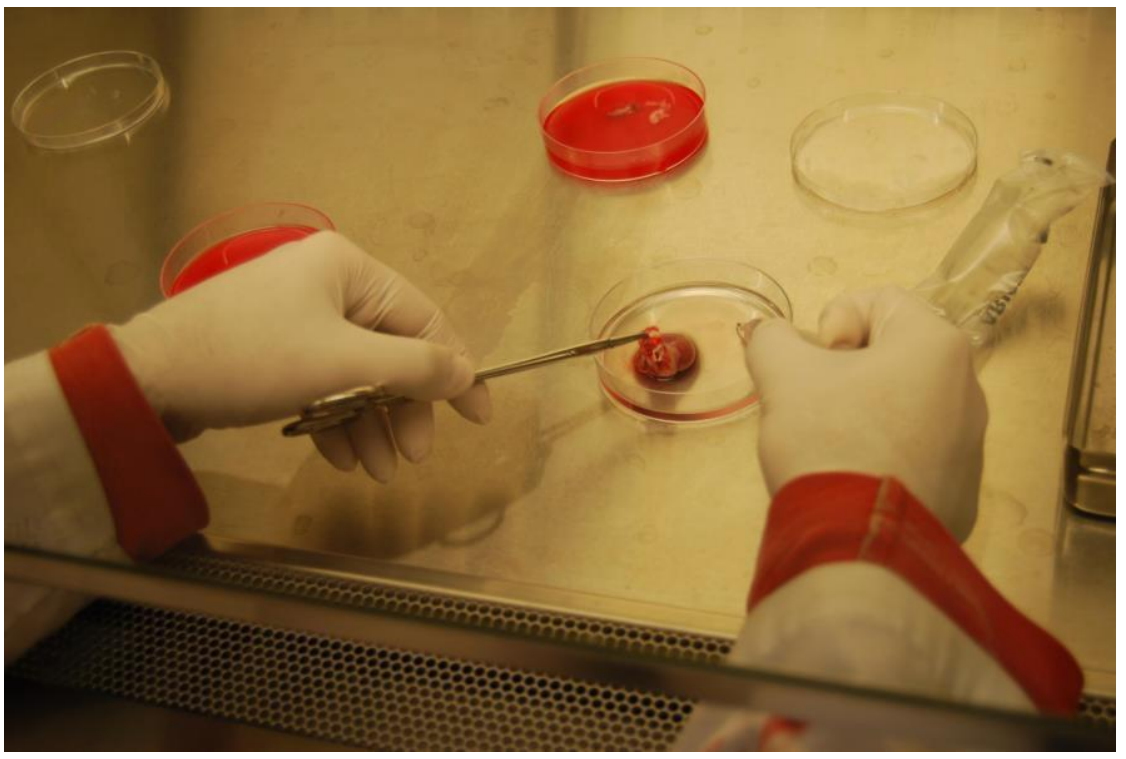

Figura 8

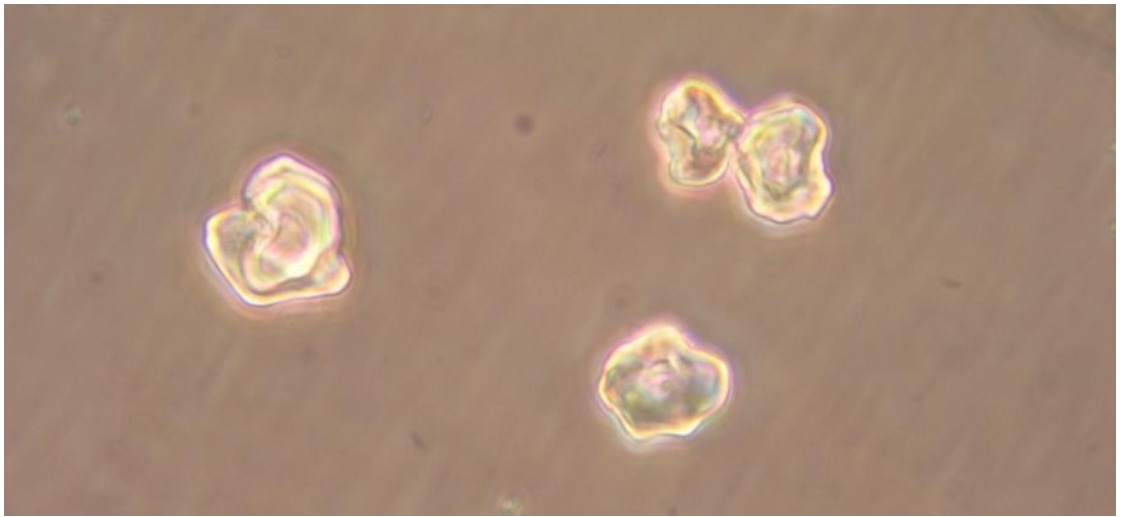

Orlan, "Harlequin Coat". Detalle del biorreactor con la mezcla de células donadas. sk-interfaces, FACT,

Liverpool, Inglaterra, 2008. () Orlan, fotografía original de Tony Nathan

\section{Joaquín Fargas,}

"Inmortalidad". Científicos de la Universidad Maimónides

extrayendo células cardíacas para la obra. Fotografía gentileza del artista.

\section{Joaquín Fargas,}

"Inmortalidad". Imagen microscópica del cultivo de mioblastos. Fotografía de Noelia Leopardo, gentileza del artista. 
Figura 9

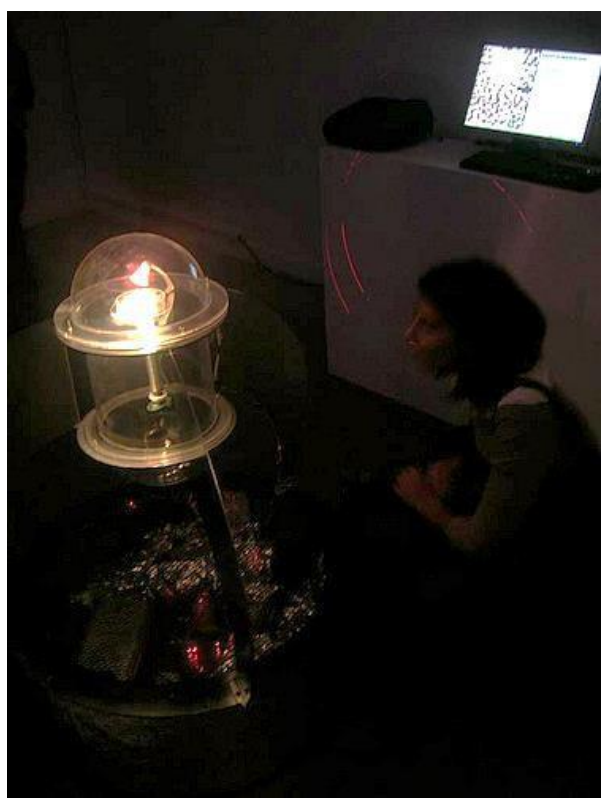

Joaquín Fargas,

"Inmortalidad". Parte de la instalación en la muestra

Naturaleza Intervenida.

Centro Cultural Recoleta,

Buenos Aires, Argentina, 2008. ๑ $90+10$

Figura 10

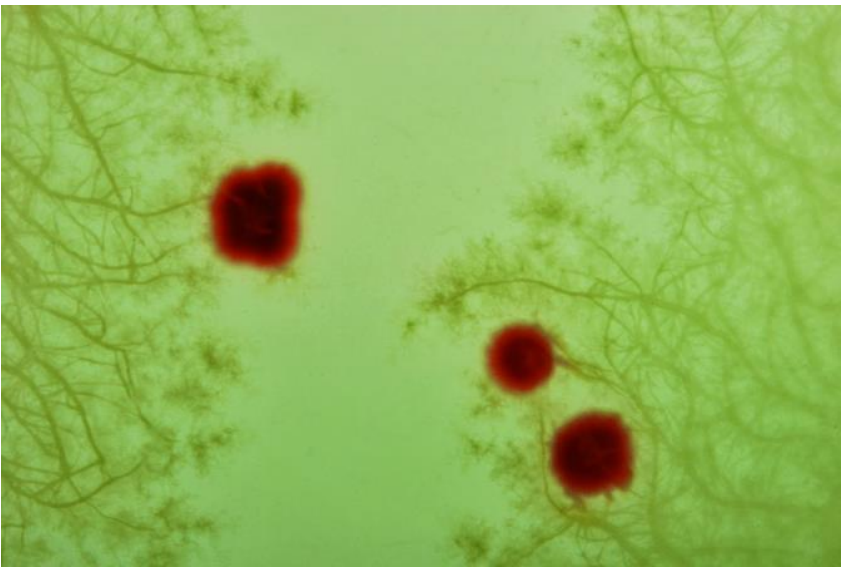

Luciana Paoletti, "Pinturas". Dibujos realizados sobre

soportes sólidos con nutrientes. Cada trazo dibujado es invisible hasta que los microorganismos comienzan a crecer y vuelven visible al dibujo de manera transitoria. Rosario, Argentina, 2012. Imagen http://visible-invisible.blogspot.com.ar

Figura 11

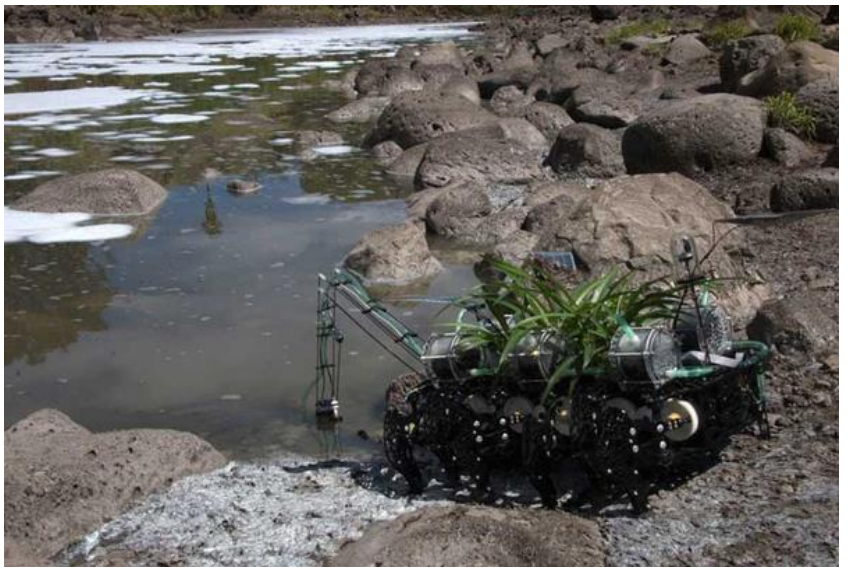

Gilberto Esparza, "Plantas Nómadas", 2008-2012. Río Santiago en el Estado de Jalisco, México, 2011. (C Gilberto Esparza

Figura 12

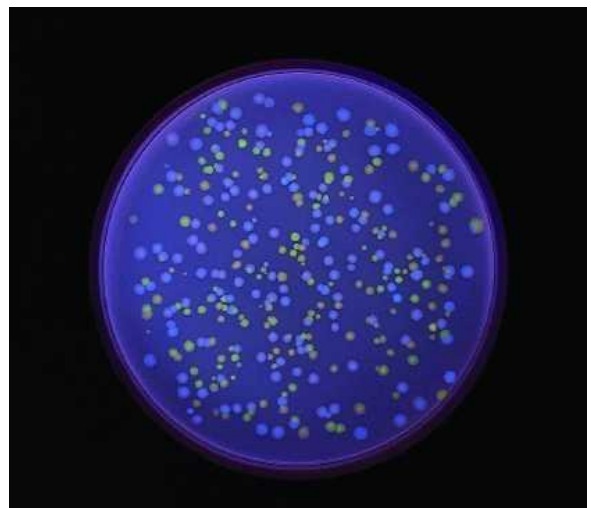

Eduardo Kac, "Genesis". Cultivo de bacterias a las que se les incorporó un plásmido que continene proteína amarilla fluorescente y otro que contiene proteína cian fluorescente. Fotografia Clontech 
Figura 13

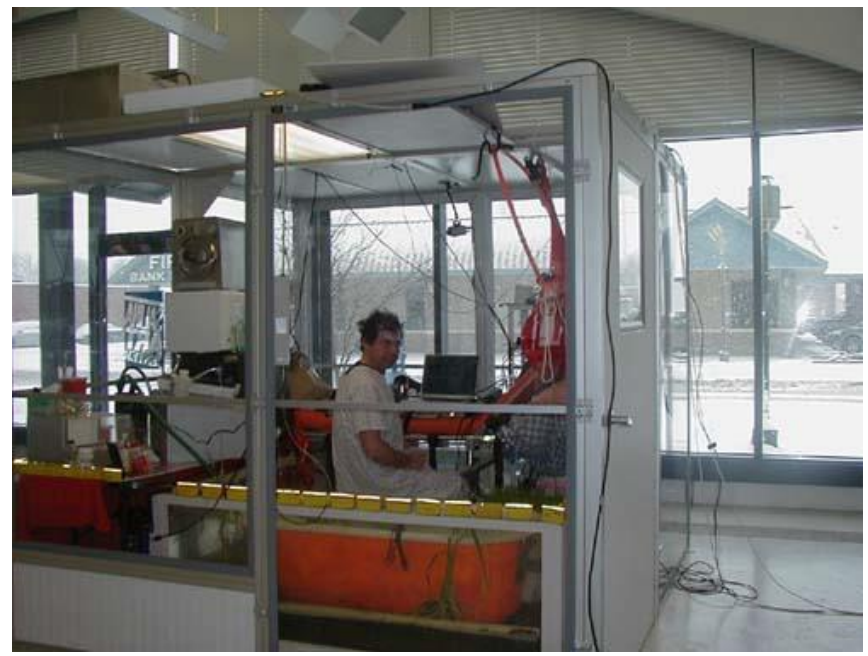

Adam Zaretsky en

colaboración con Julia

Reodica, "Workhorse Zoo".

Imagen del artista viviendo

en el cuarto aséptico

instalado en el Salina Art

Center, Kansas, Estados

Unidos, 2002. Imagen

www.emutagem.com

Figura 14

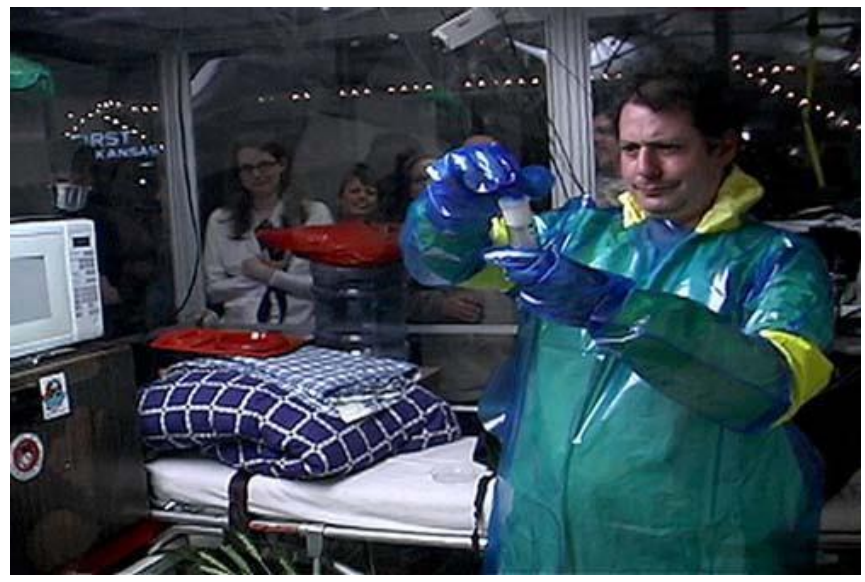

Figura 15

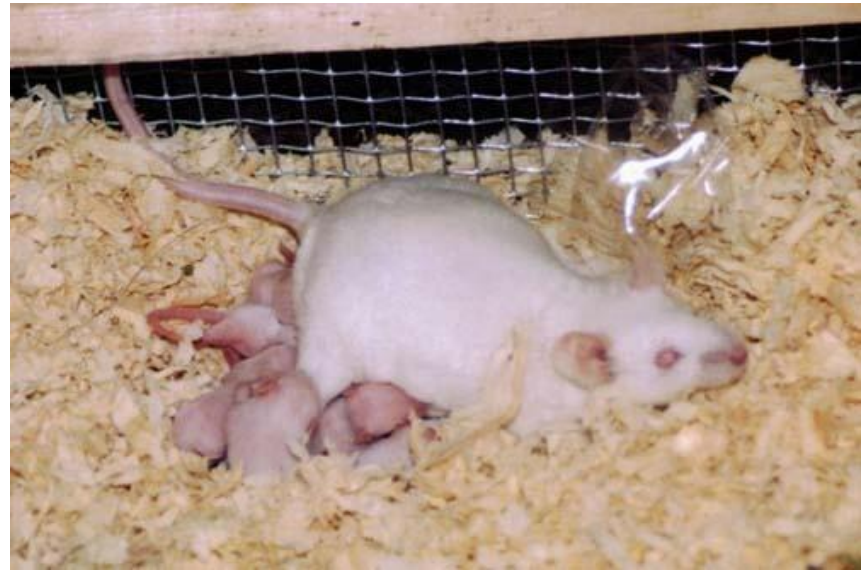

Adam Zaretsky en

colaboración con Julia

Reodica, "Workhorse Zoo".

Liberación de moscas

Drosophila. Salina Art

Center, Kansas, Estados

Unidos, 2002. Imagen

www.emutagem.com

Adam Zaretsky en

colaboración con Julia

Reodica, "Workhorse Zoo".

Ratón preñado que tuvo cría

durante la performance.

Salina Art Center, Kansas,

Estados Unidos, 2002.

Imagen www.emutagem.com

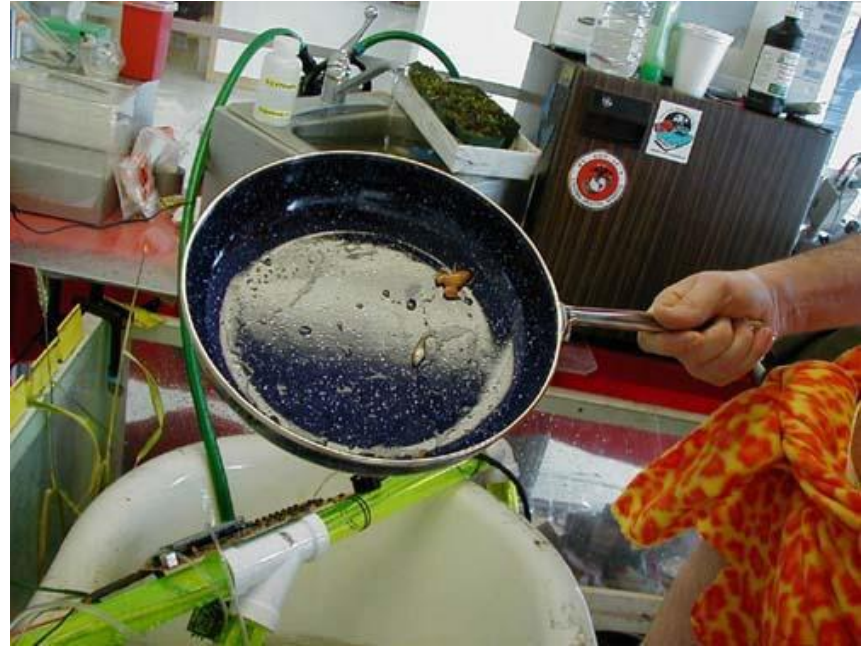

Adam Zaretsky en

colaboración con Julia

Reodica, "Workhorse Zoo".

El artista cocinando al

Xenopus. Salina Art Center,

Kansas, Estados Unidos,

2002. Imagen

www.emutagem.com 
Figura 17

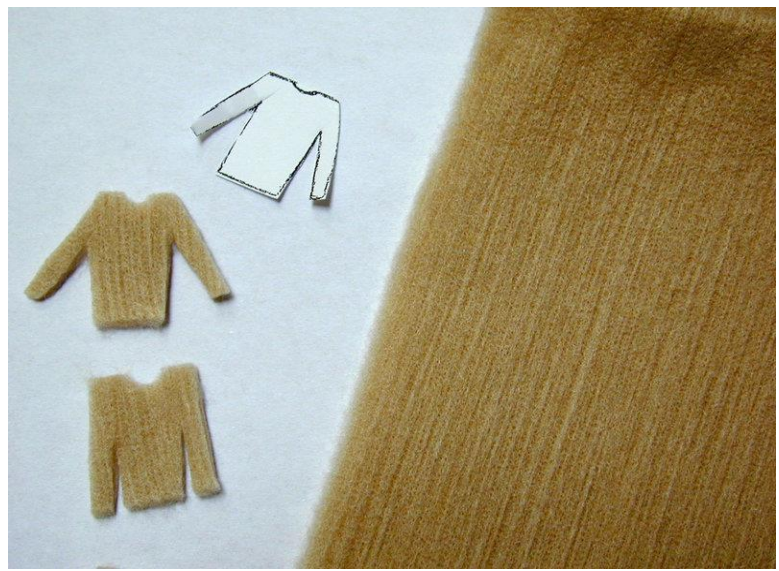

Tissue Culture \& Art

Project, "Victimless

Leather". Prototipo de

chaqueta sin costuras para

que crezca en un cuerpo

tecnocientífico. Desde 2004.

(c) TC\&A

Figura 18

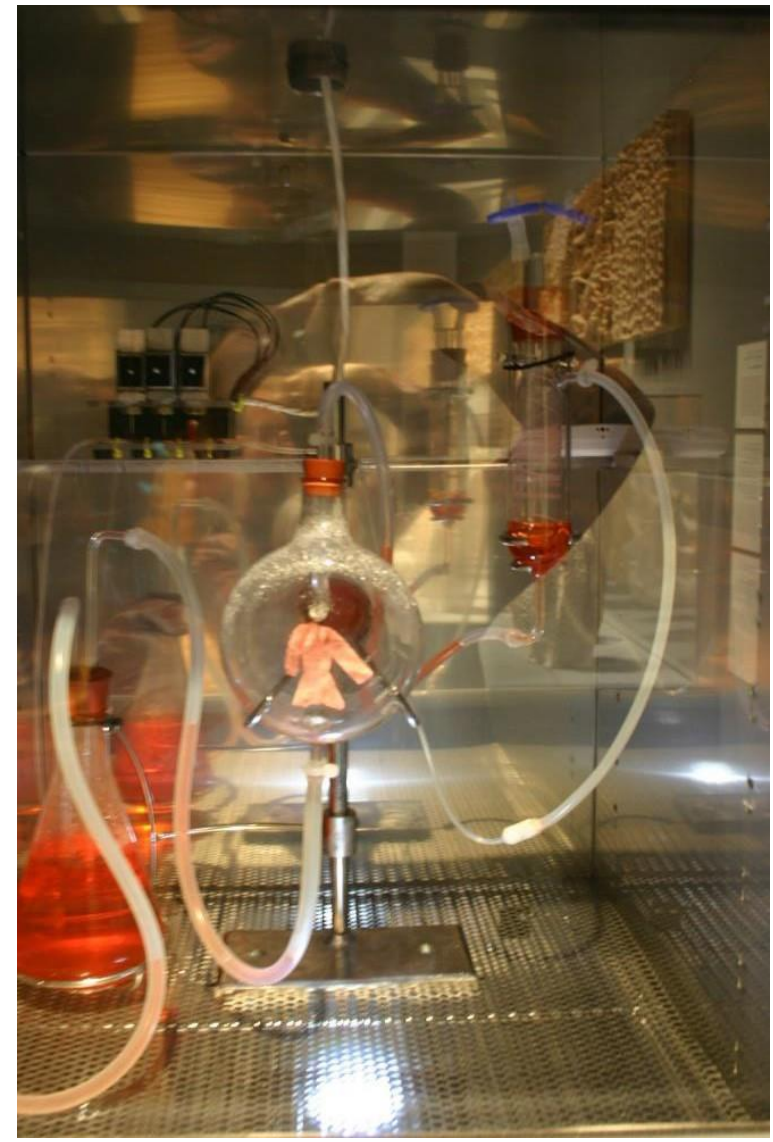

Tissue Culture \& Art

Project, "Victimless

Leather". Muestra Design

and the Elastic Mind, MOMA,

New York, Estados Unidos,

2008. Imagen Ryan Somma

(ㄷ)(1)

Figura 19

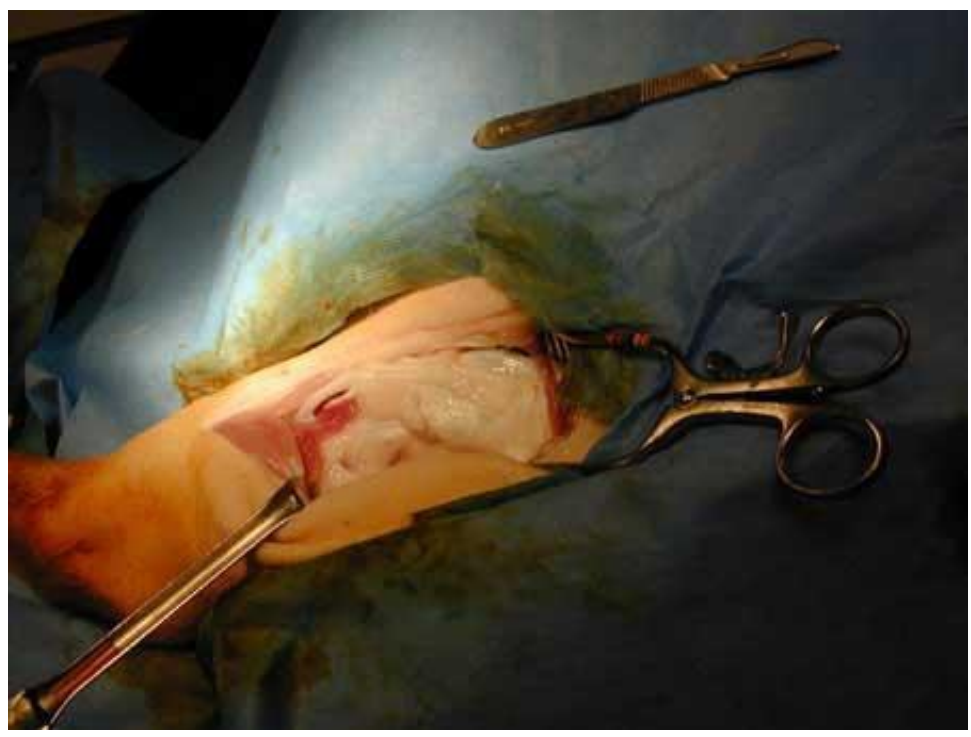

Tissue Culture \& Art

Project, "The Pig Wings

Project". Proceso de

recolección de células de

cerdo. 2000-2001. @ TC\&A 
Figura 20

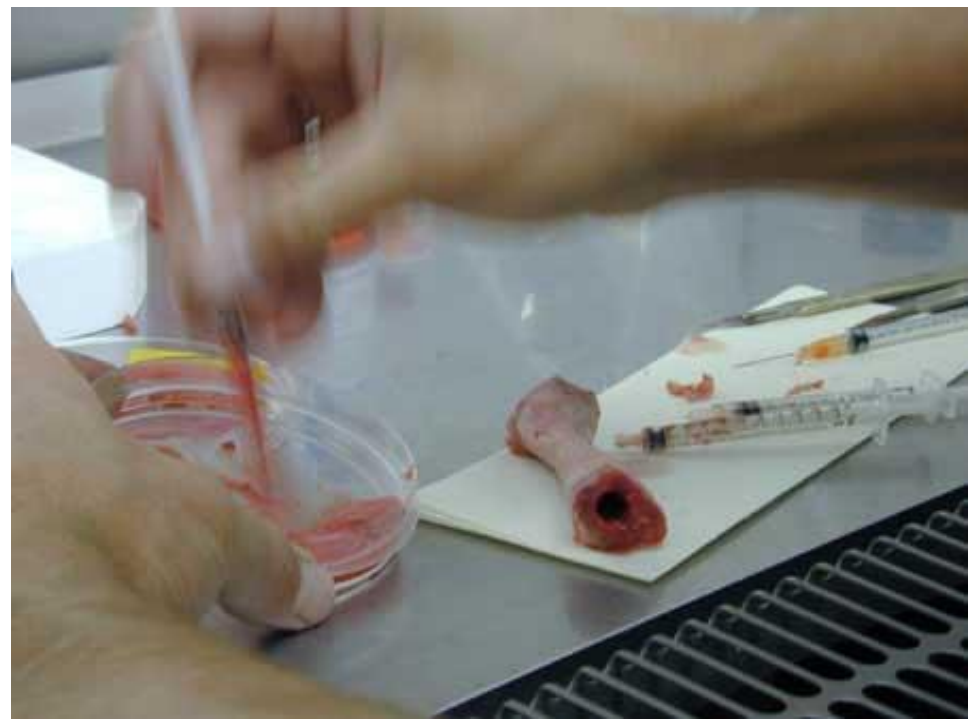

Figura 21
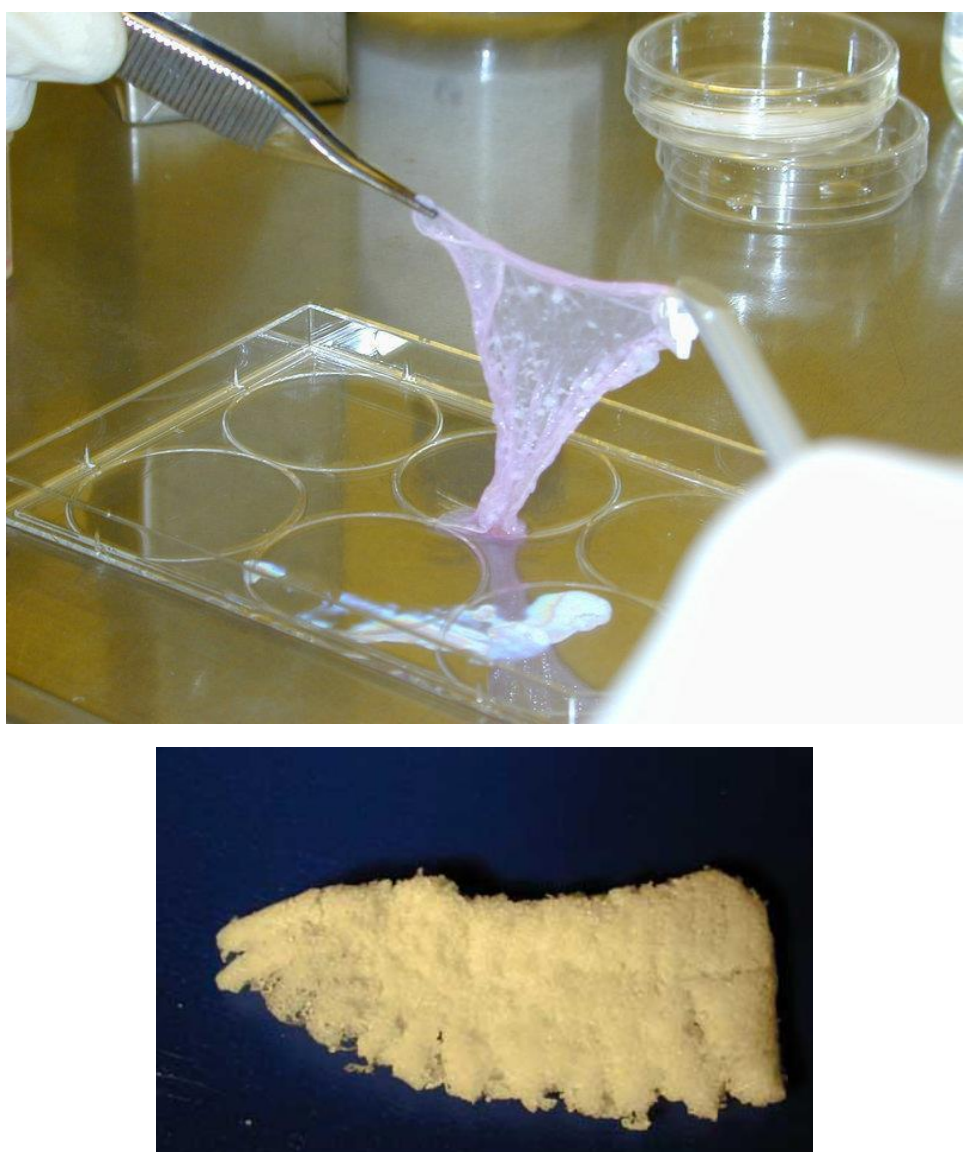

Figura 22
Tissue Culture \& Art Project, "The Pig Wings Project". Extracción de células mesenquimales. 2000-2001. ๑ TC\&A

Tissue Culture \& Art Project, "The Pig Wings

Project". Cultivo tisular bidimensional. 2000-2001. () TC\&A
Tissue Culture \& Art Project, "The Pig Wings Project". Estructuras poliméricas con forma de alas. 2000-2001. (C TC\&A 
Figura 23

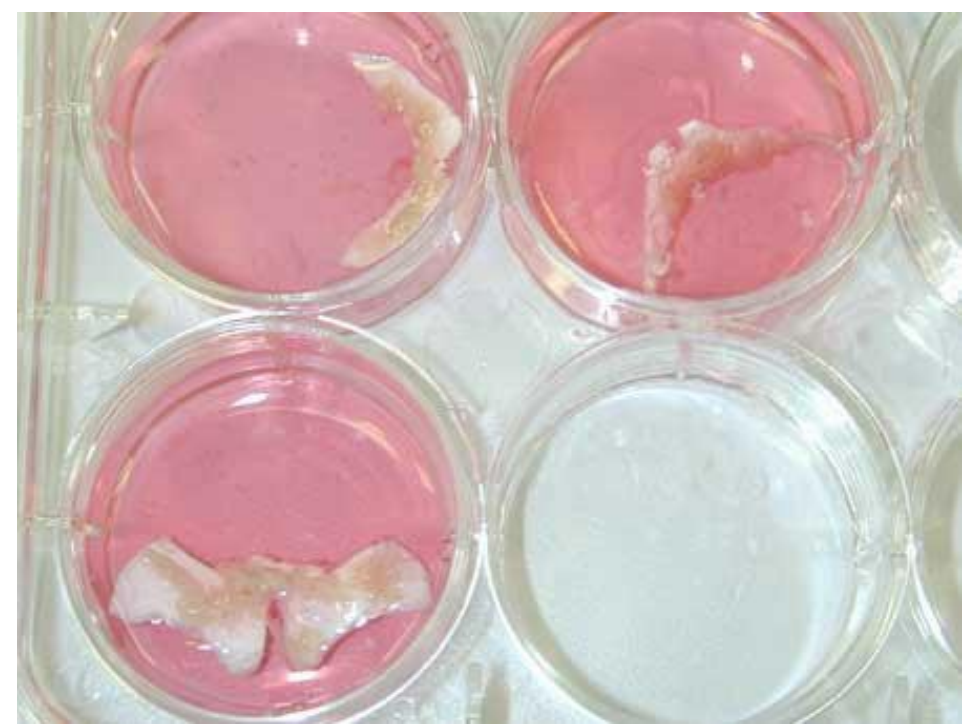

Tissue Culture \& Art

Project, "The Pig Wings Project". Estructuras aladas semi-vivas. 2000-2001. (๑) TC\&A

Figura 24

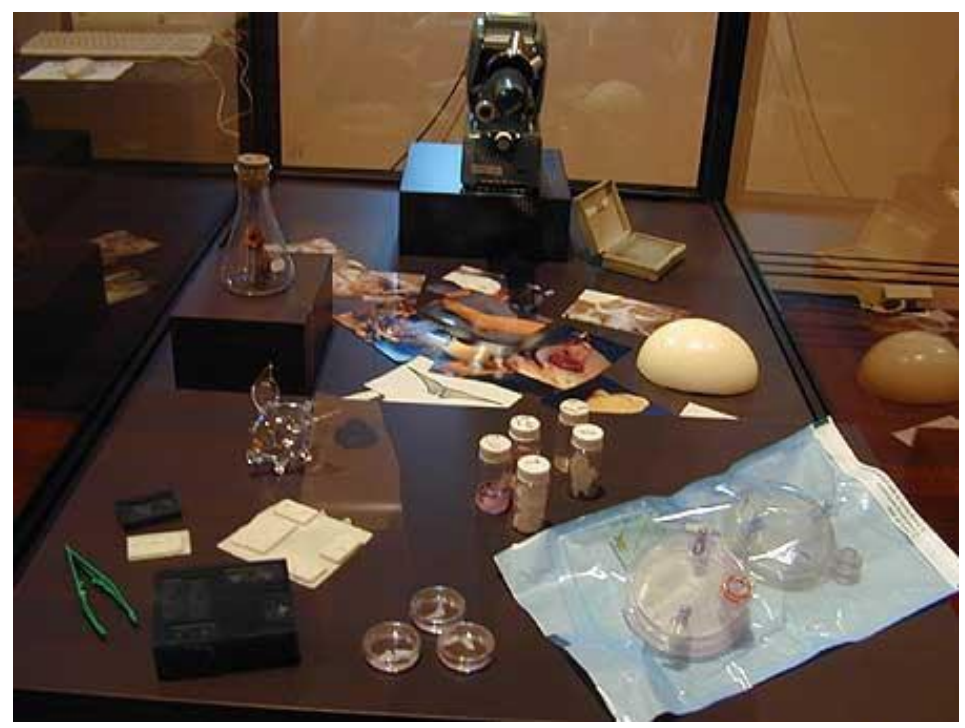

Tissue Culture \& Art Project, "The Pig Wings

Project". Detalle de la

muestra: vitrinas de

exhibición. (0)TC\&A

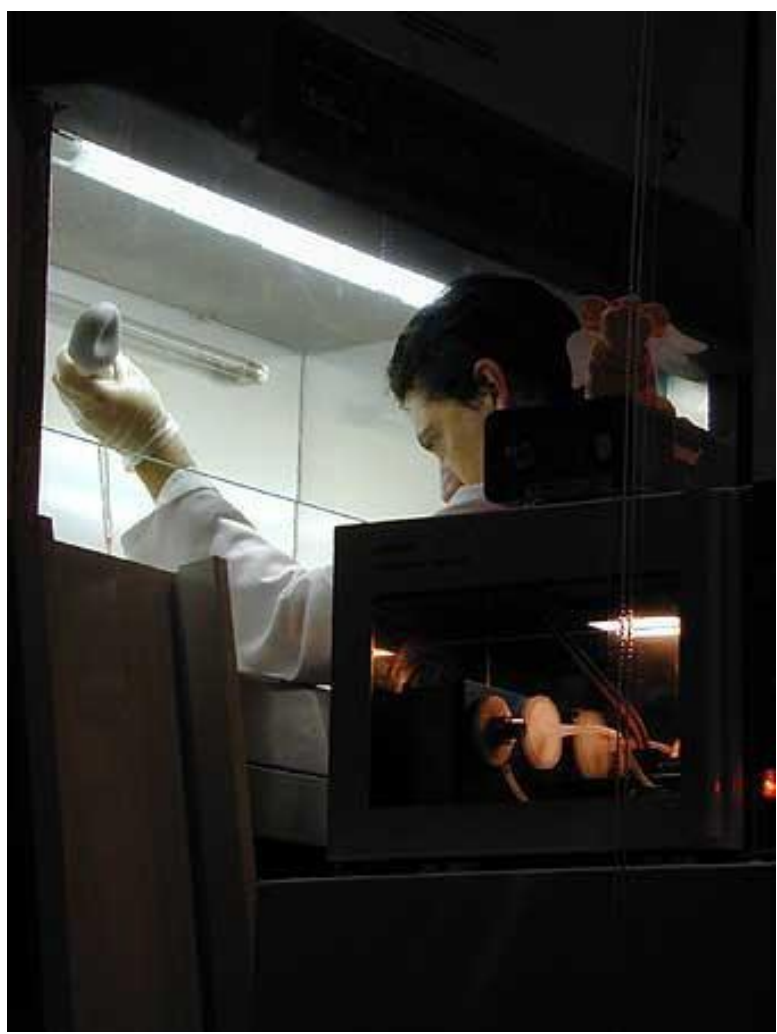

Tissue Culture \& Art

Project, "The Pig Wings

Project". Detrás: Oron Catts

trabajando en la cabina de

bioseguridad. Delante:

biorreactor giratorio. (C) TC\&A 

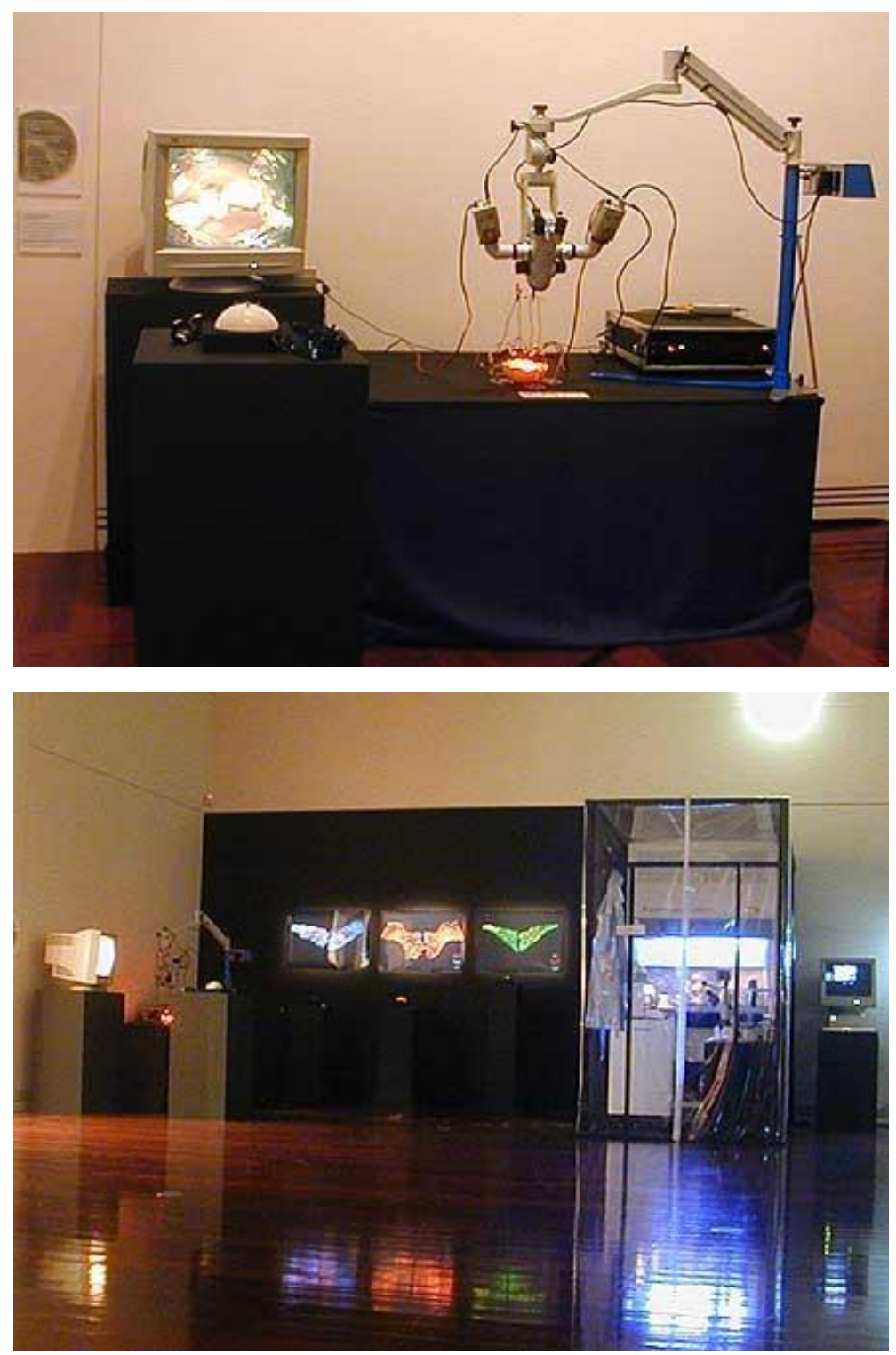

Figura 28

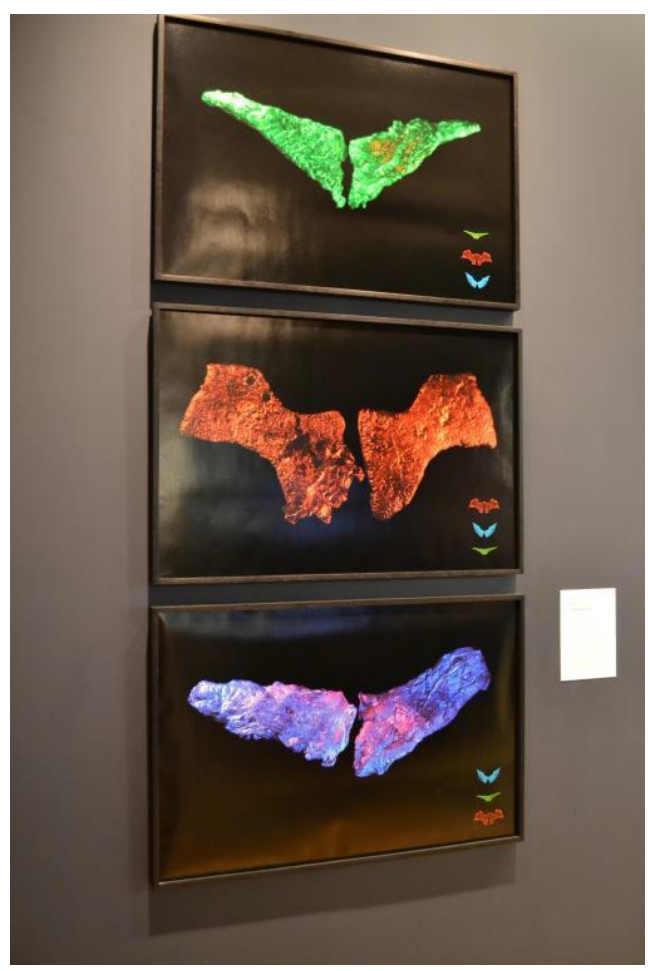

Tissue Culture \& Art Project, "The Pig Wings Project". Visualización de imágenes microscópicas de cultivo. @ TC\&A

Tissue Culture \& Art Project, "The Pig Wings Project". Vista general de la muestra. (C) TC\&A

Tissue Culture \& Art Project, "The Pig Wings Project". C-print (61,6 x 91,8 $\times 3,5 \mathrm{~cm}$, cada una).

Museum of Modern Art,

Nueva York, 2013.

Fotografía Sergio Moyinedo 
Figura 29

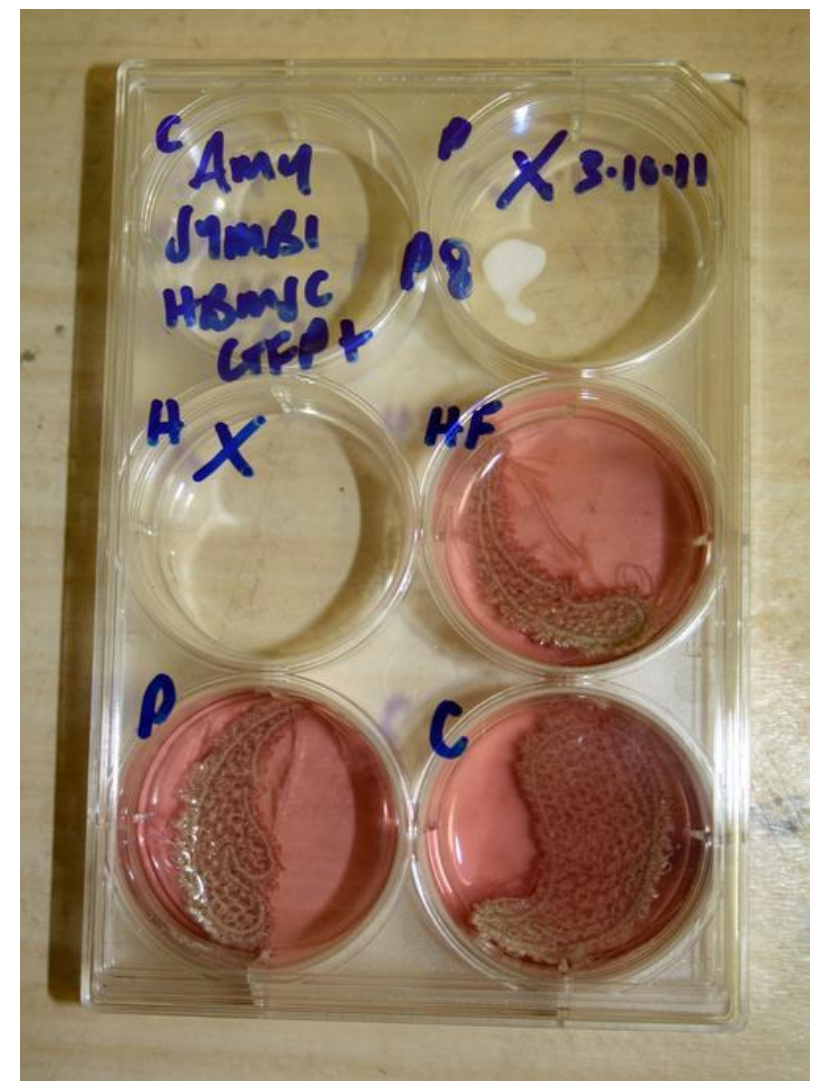

Amy Congdon, "Biological Bespoke". Células HBMSC

creciendo en la matriz

bordada. SymbioticA, UWA,

Perth, Australia, 2011. ()

Amy Congdon

Figura 30

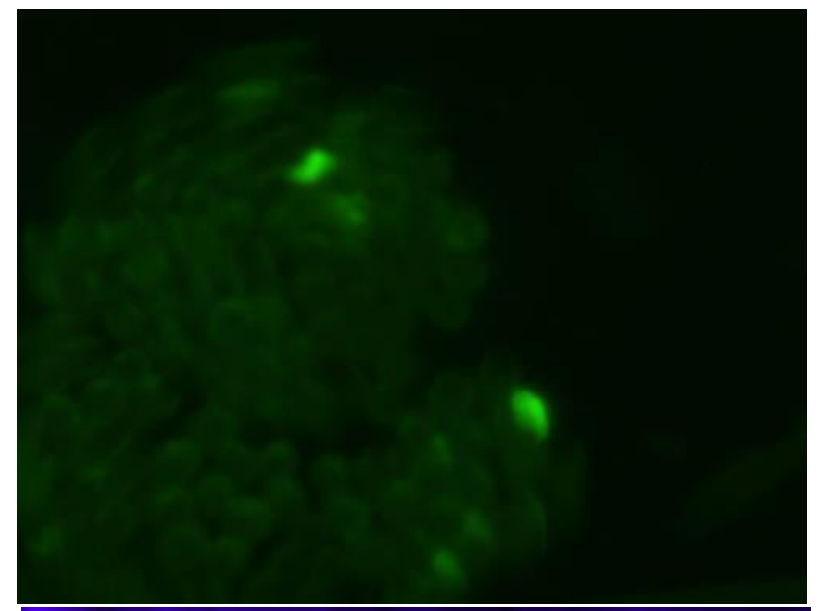

Amy Congdon, "Biological Bespoke". Imágenes

microscópicas de las células fijadas al bordado.

SymbioticA, UWA, Perth,

Australia, 2011. @ Amy

Congdon 
Figura 31

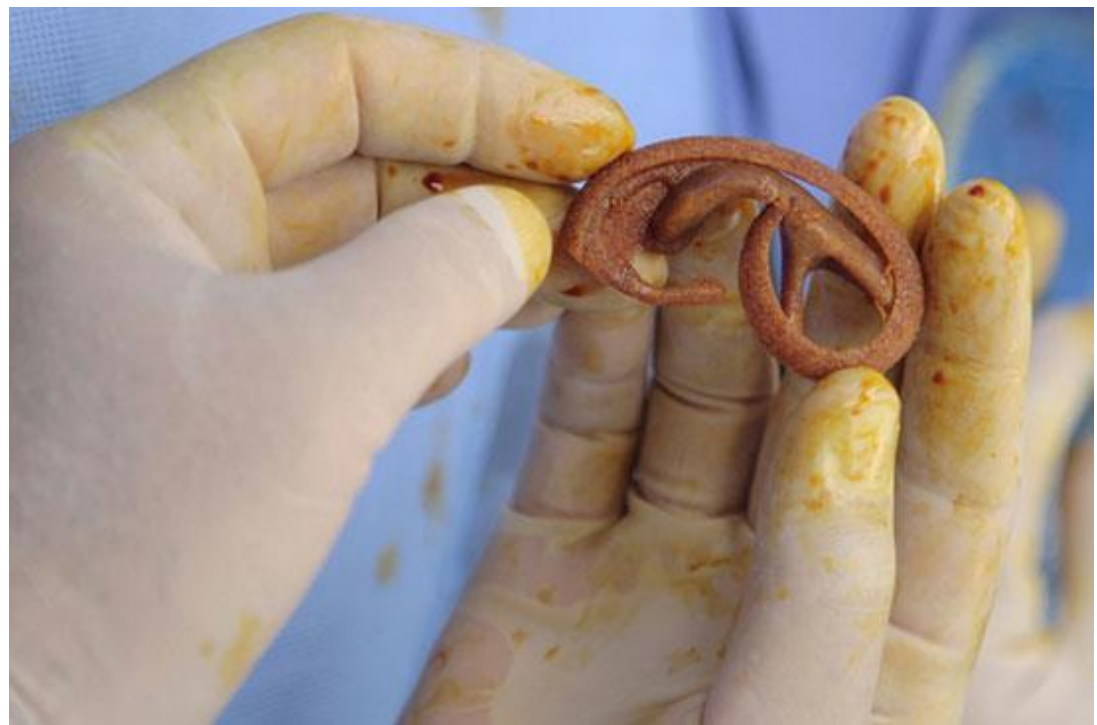

Stelarc, "Ear on Arm".

Imagen de la prótesis

biocompatible con forma de

oreja. Los Ángeles, Estados

Unidos, 2006. Fotografía

Nina Sellars

Figura 32

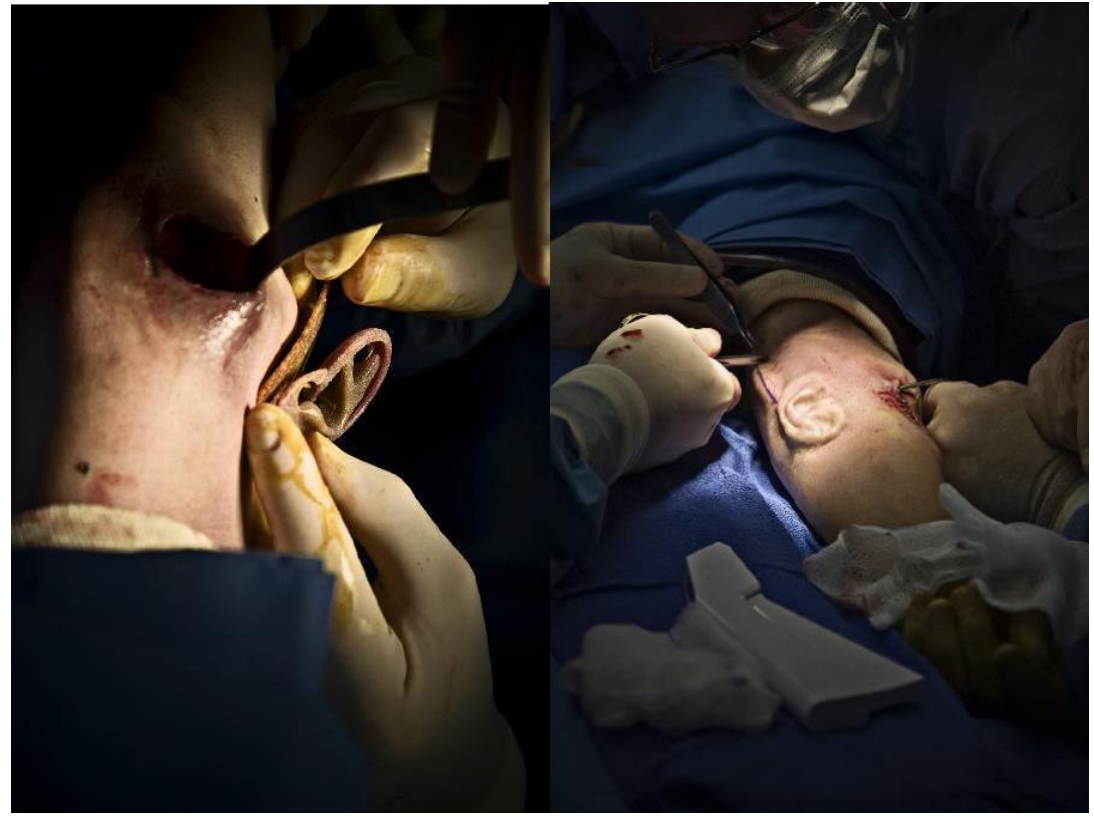

Stelarc, "Ear on Arm". Dos momentos de la cirugía donde se le implanta la

prótesis al artista. Los Ángeles, Estados Unidos, 2006. Fotografía Nina

Sellars

Figura 33

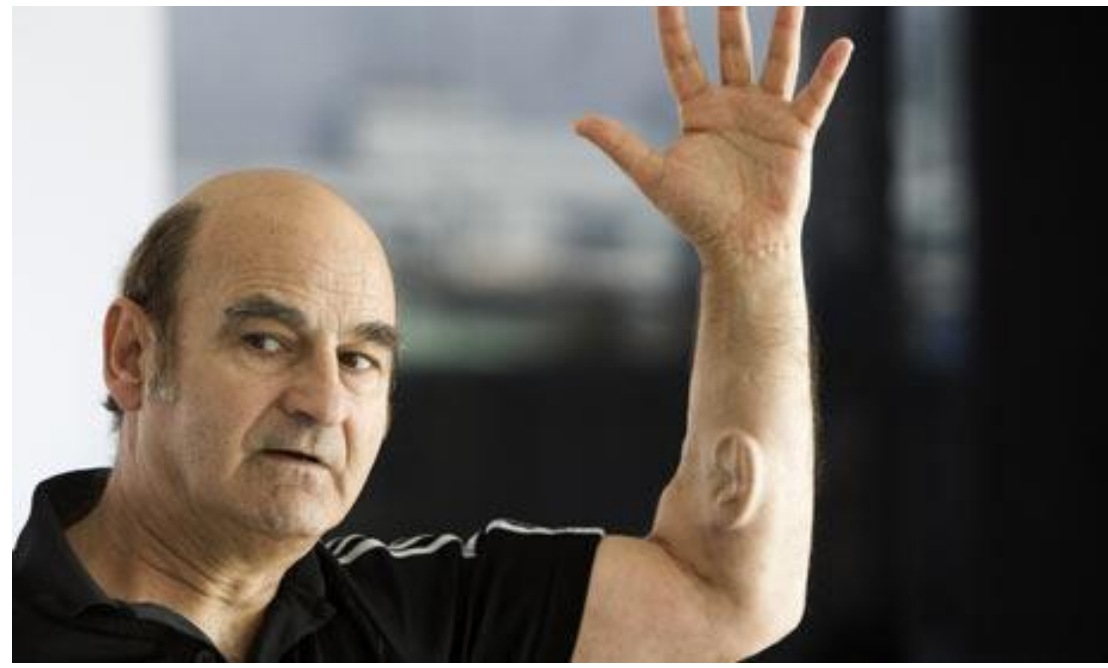

Stelarc, "Ear on Arm".

Performance realizada en el

Festival de Ciencia de

Edimburgo. Edimburgo,

Escocia, 2009. Fotografía

Murdo Macleod 
Figura 34
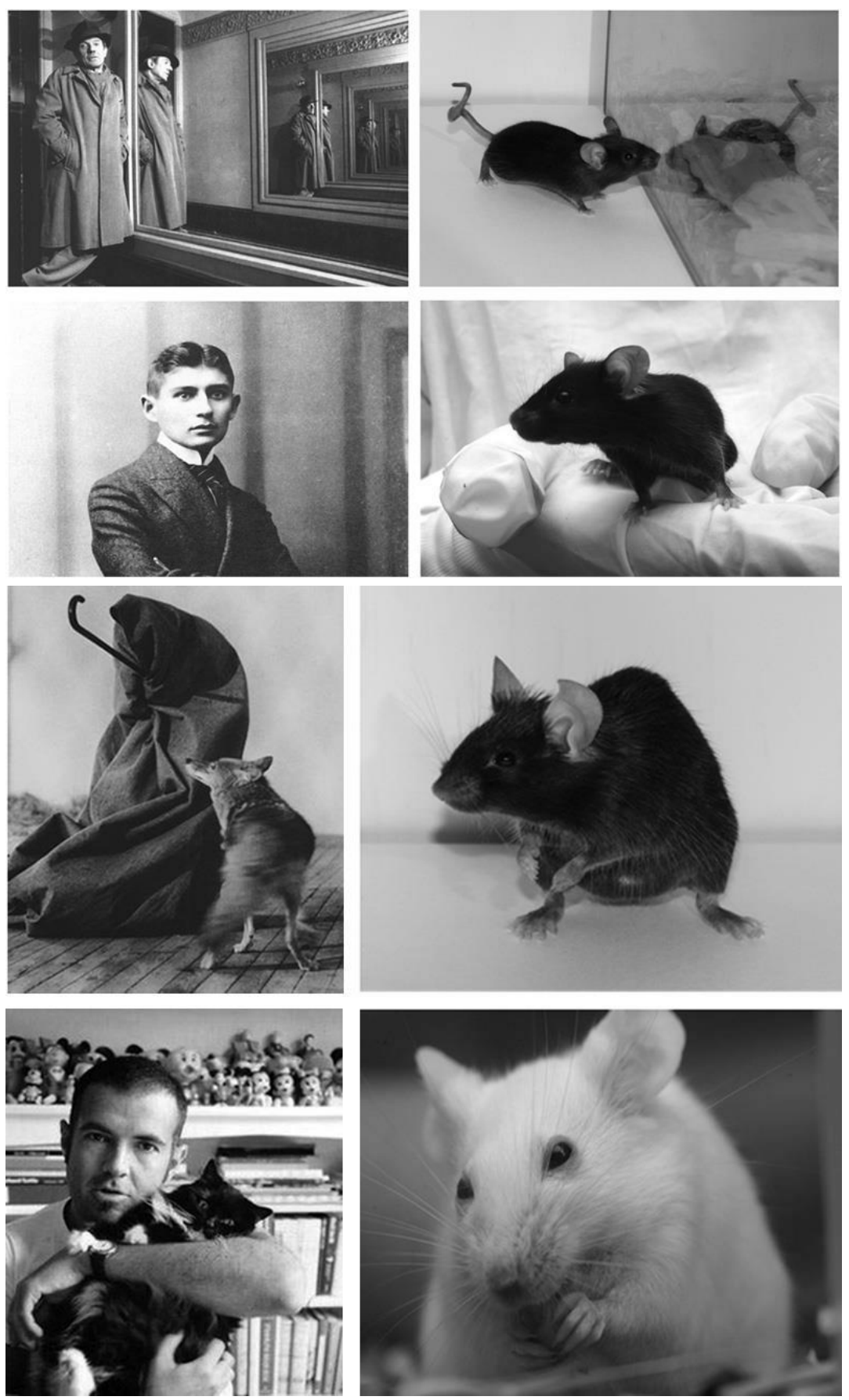

Figura 35

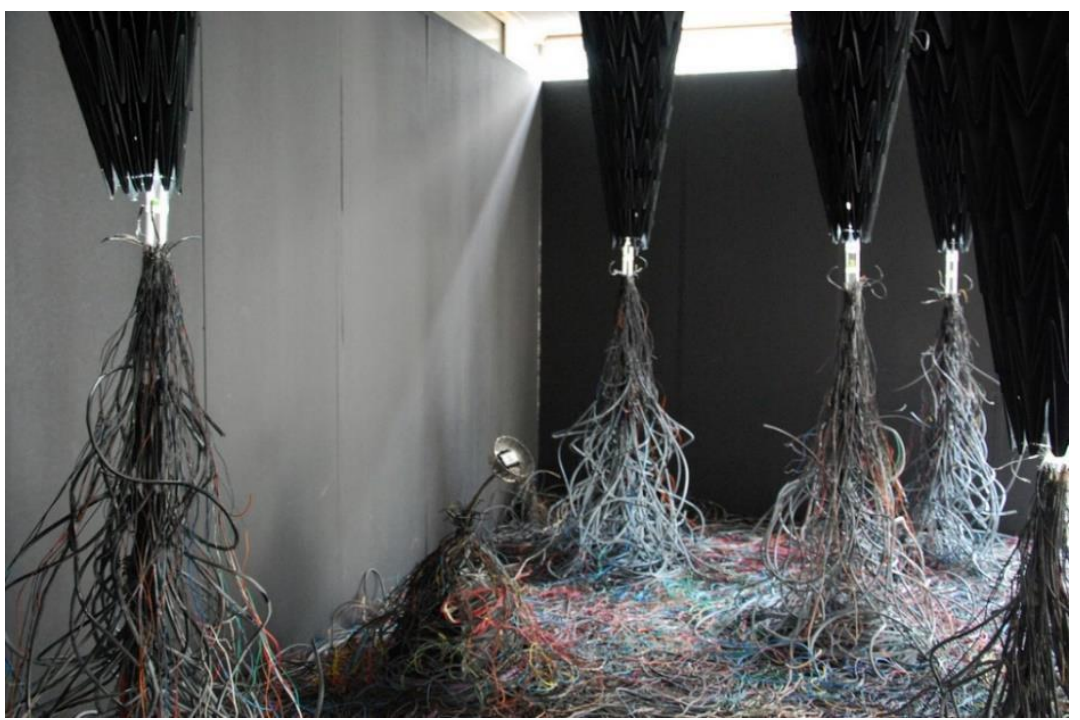

Verena Kaminiarz, "May the mice bite me if it is not true". A la izquierda, y de arriba hacia abajo, los retratos de Gilles Deleuze, Franz Kafka, Joseph Beuys y Félix González Torres. Ala derecha, y de arriba hacia abajo, los ratones

transgénicos Gilles, Franz, Joseph y Félix. SymbioticA, UWA, Perth, Australia, 2008.

Imagen

www.verenakaminiarz.com

Proyecto Untitled, "Edenia". Vista general de la

instalación que incluye a las orquídeas in vitro y la planta robótica Floris Lupus.

Muestra Cultura y Media,

Centro Cultural General San Martín, Buenos Aires,

Argentina, 2010. ๔

Multimedia Maimónides. 
Figura 36

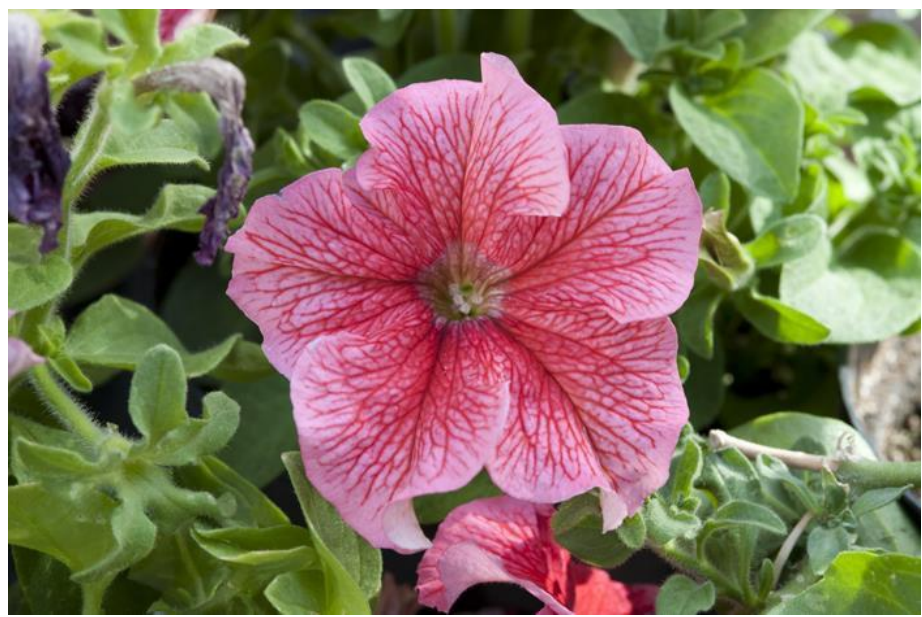

Eduardo Kac, "Natural History of the Enigma", 2003-2008. Detalle de

Edunia, la flor transgénica que expresa el ADN de Kac en las nervaduras rojas.

Weisman Art Museum.

Minneapolis, Estados

Unidos, 2009. Fotografía Rik Sferra

Figura 37

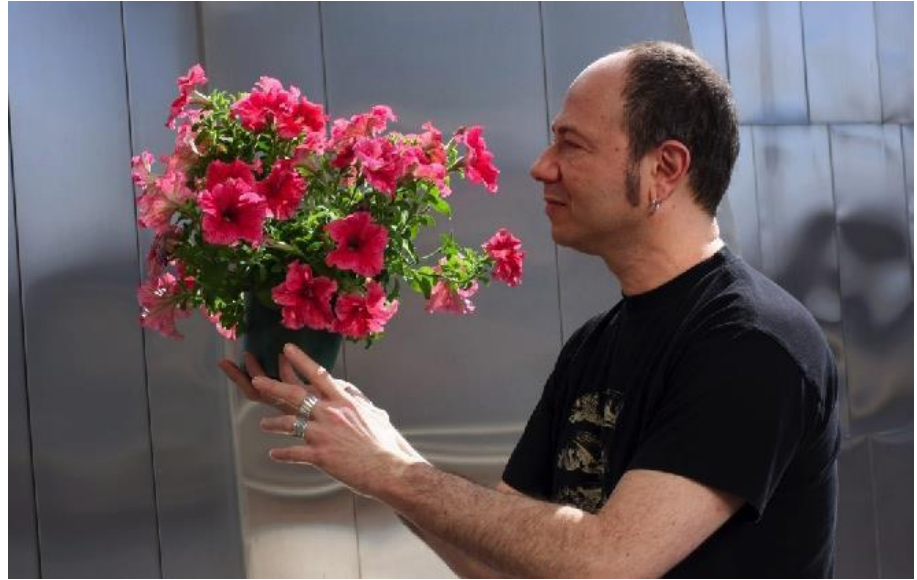

Figura 38

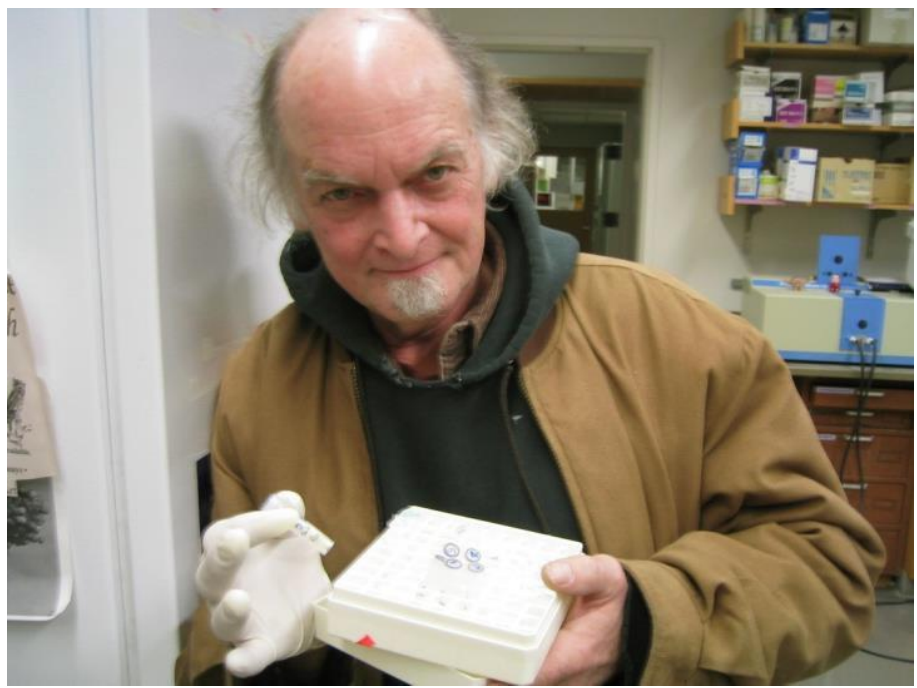

Figura 39

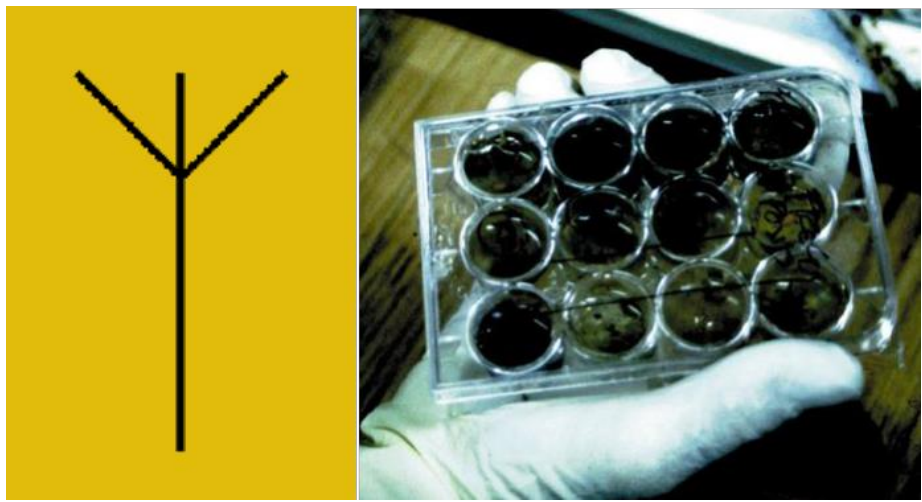

Joe Davis. Imagen de artista tomada en el

Laboratorio de Bioquímica, Biofísica y Estructura Molecular en el Instituto

Tecnológico de

Massachusetts (MIT), de la

Universidad de Cambridge,

Estados Unidos. Fotografía

(c) Emily Voigt

Joe Davis, "Microvenus", 1986. A la izquierda, signo germánico antiguo que representa a la Tierra femenina. A la derecha, imagen de las moléculas sintéticas de ADN. @ Joe Davis 
Figura 40

Figura 41

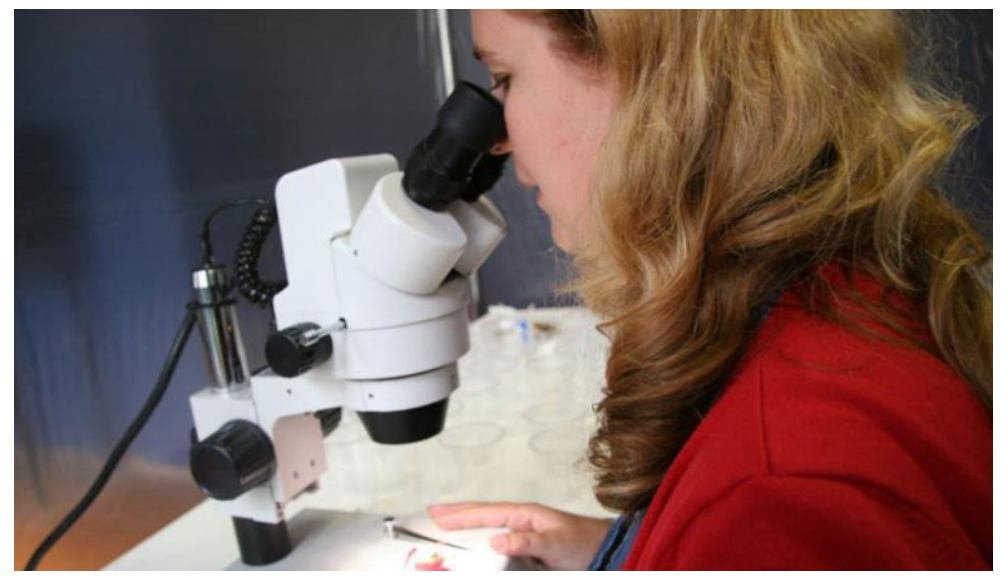

Marta de Menezes,

Universidad de Leiden,

Holanda, 1999. @ Marta de

Menezes

Marta de Menezes. Imagen de la microcauterización del capullo. Universidad de Leiden, Holanda, 1999. @ Marta de Menezes

Figura 42

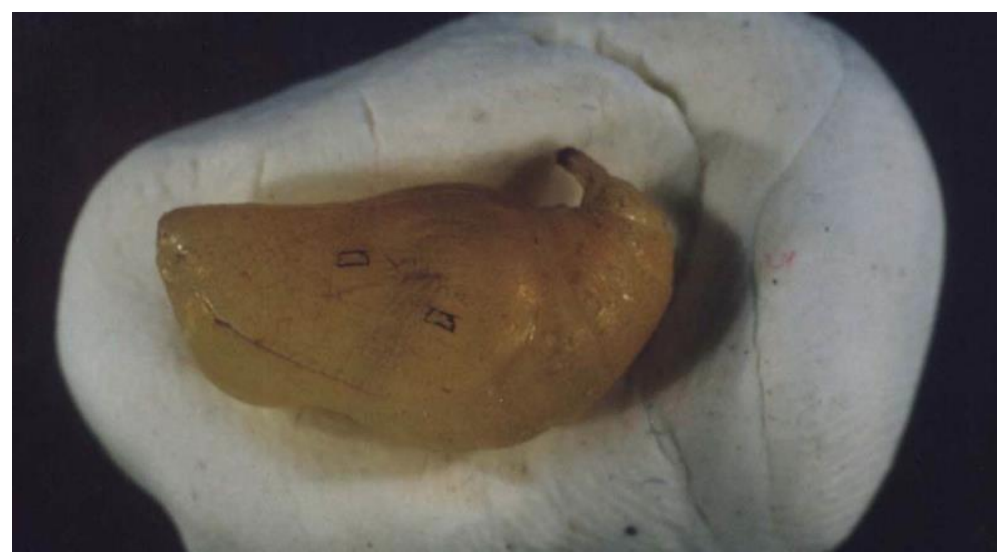

Figura 43

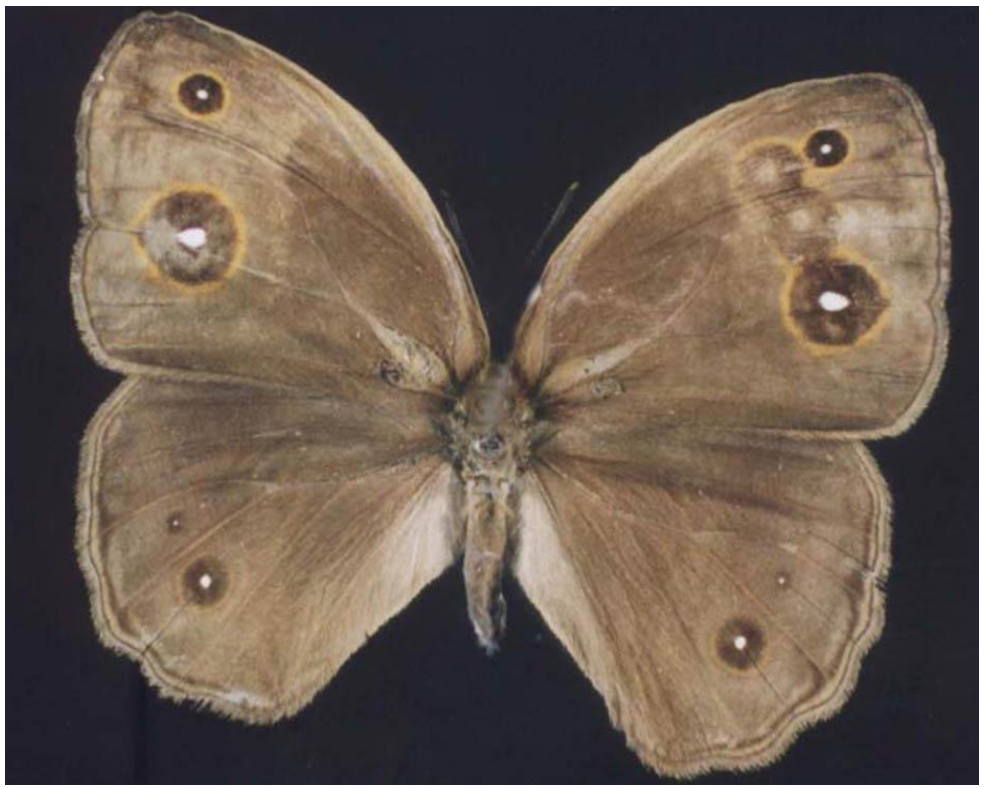

Marta de Menezes, Detalle del capullo de la mariposa. Universidad de Leiden,

Holanda, 1999. @ Marta de Menezes

\section{Marta de Menezes,}

"Nature?". La modificación

se observa únicamente en el ala derecha de la mariposa.

Ars Electronica, Linz,

Austria, 2000. @ Marta de Menezes 
Figura 44

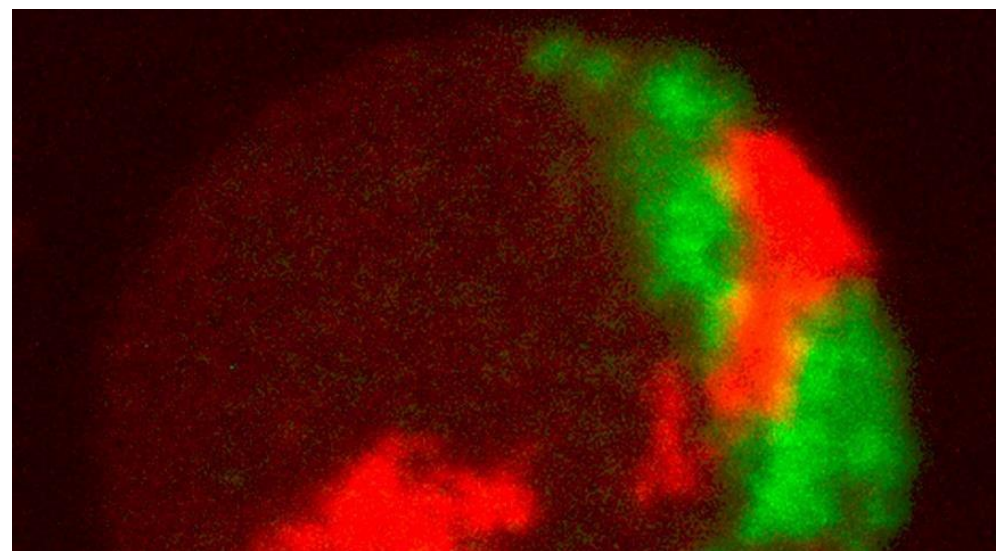

Marta de Menezes,

"Nucleart". Imagen

microscópica de la célula

coloreada con tintes

biológicos. Imperial College,

Londres, Reino Unido. ()

Marta de Menezes

Figura 45

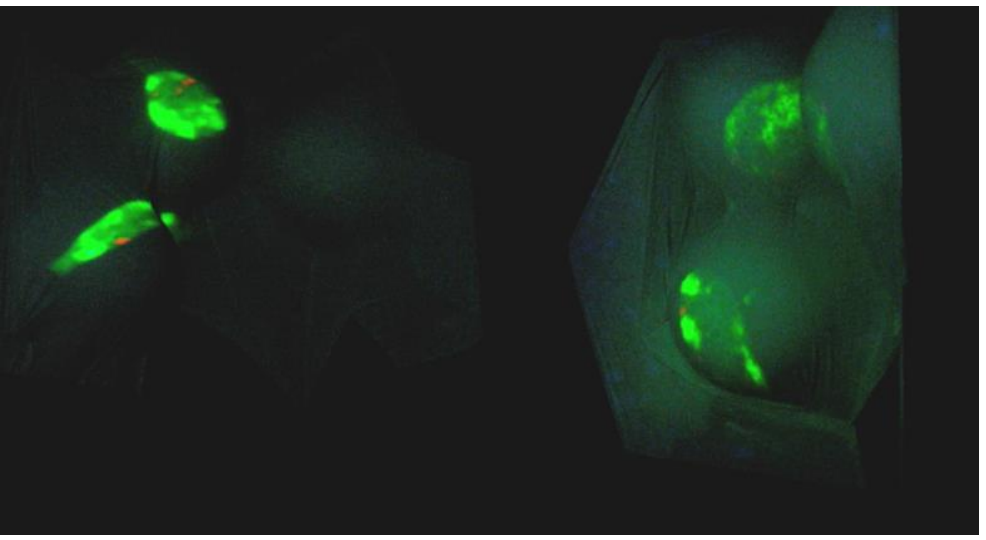

Marta de Menezes,

"Nucleart". Videoproyección sobre pantallas curvas

translúcidas. 2002. @ Marta de Menezes

Figura 46

Figura 47

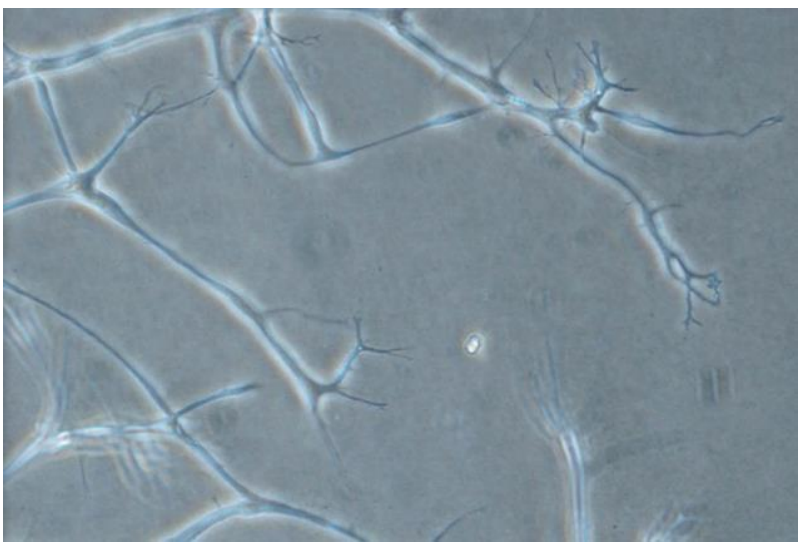

Marta de Menezes, "Tree of knowledge". Imagen microscópica del cultivo

neuronal. SymbioticA, UWA Perth, Australia, 2004-2005.

(c) Marta de Menezes

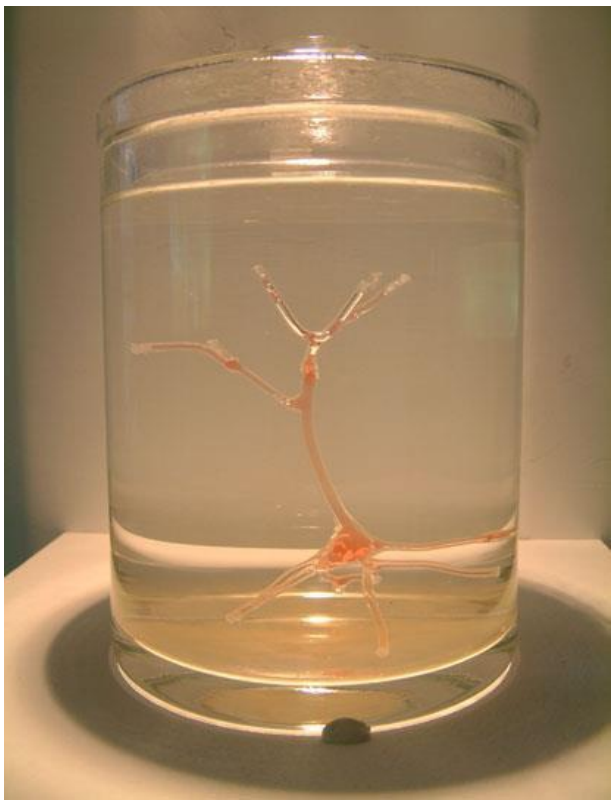

Marta de Menezes, "Tree of knowledge". Escultura con neuronas vivas. SymbioticA UWA, Perth, Australia, 2005. (c) Marta de Menezes 
Figura 48

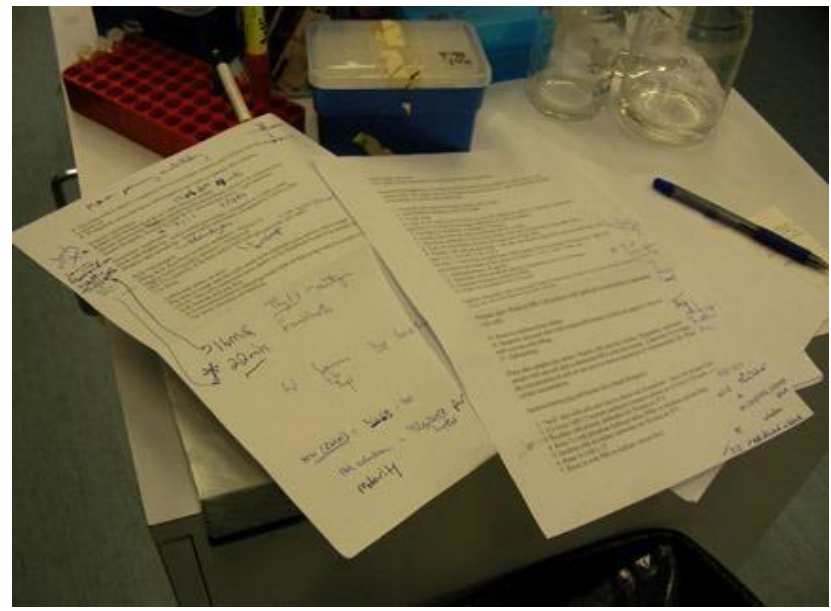

Tagny Duff, "Cryobooks". El nuevo protocolo científico en proceso de revisión.

SymbioticA, UWA, Perth, Australia, 2009. Imagen cryobookarchives. word press.com

Figura 49

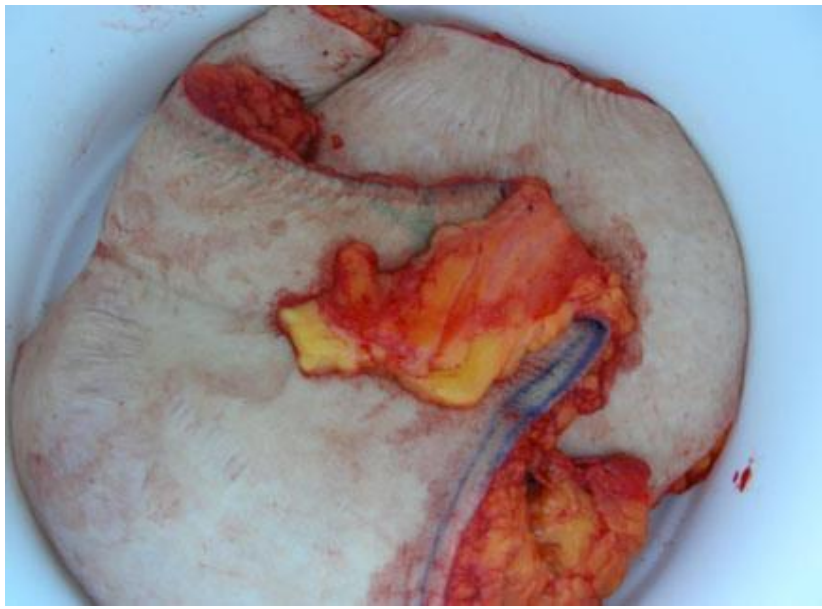

Figura 50

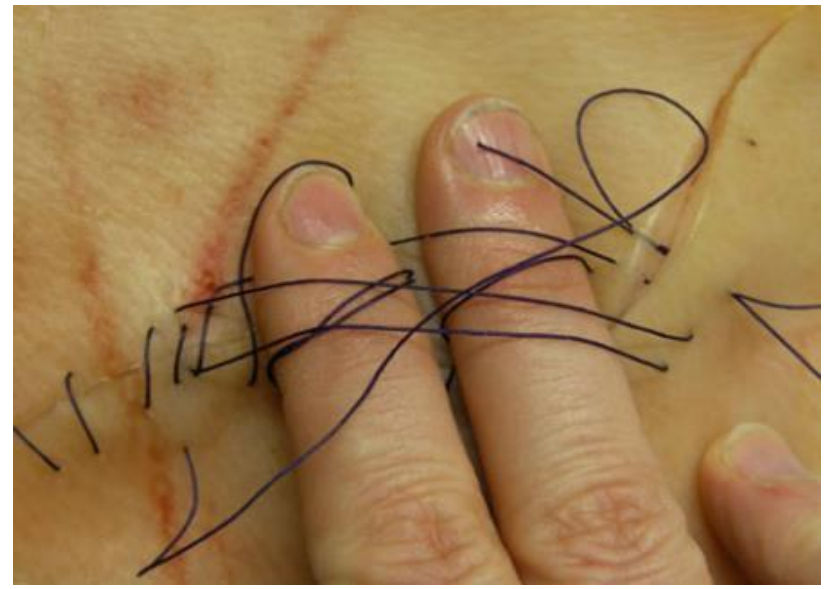

Figura 51

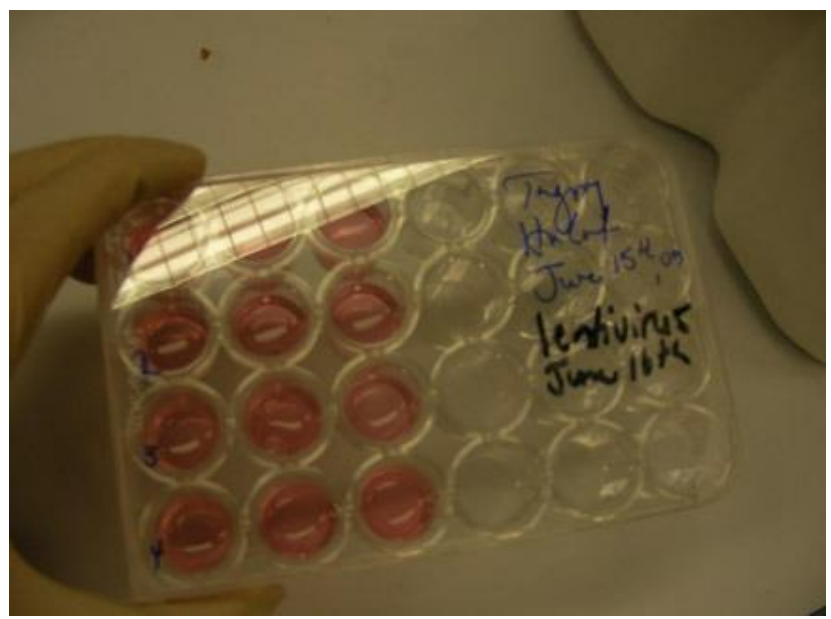

Tagny Duff, "Cryobooks". Imagen de la piel sobrante de la abdominoplastia. SymbioticA, UWA, Perth, Australia, 2009. Imagen cryobookarchives. word press.com

Tagny Duff, "Cryobooks". La artista practicando suturas. SymbioticA, UWA, Perth, Australia, 2009. Imagen cryobookarchives.word press.com

Tagny Duff, "Cryobooks".

Transducción del lentivirus a las células HaCat.

SymbioticA, UWA, Perth, Australia, 2009. Imagen cryobookarchives. wordpress.com 
Figura 52

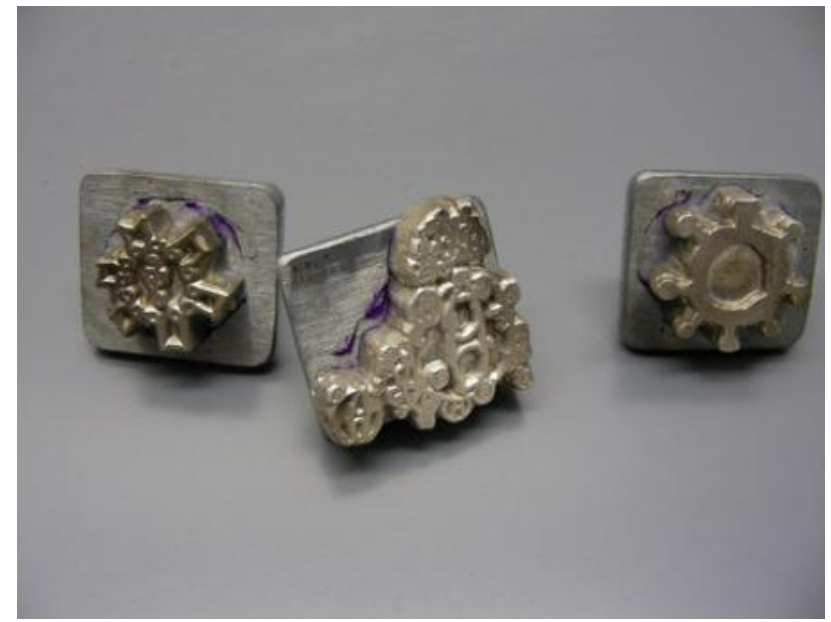

Tagny Duff, "Cryobooks".

Sellos con diseños de John

Greyson, Vincent Chevalier y

Tagny Duff. SymbioticA,

UWA, Perth, Australia, 2009.

Imagen

cryobookarchives.word press.com

Figura 53

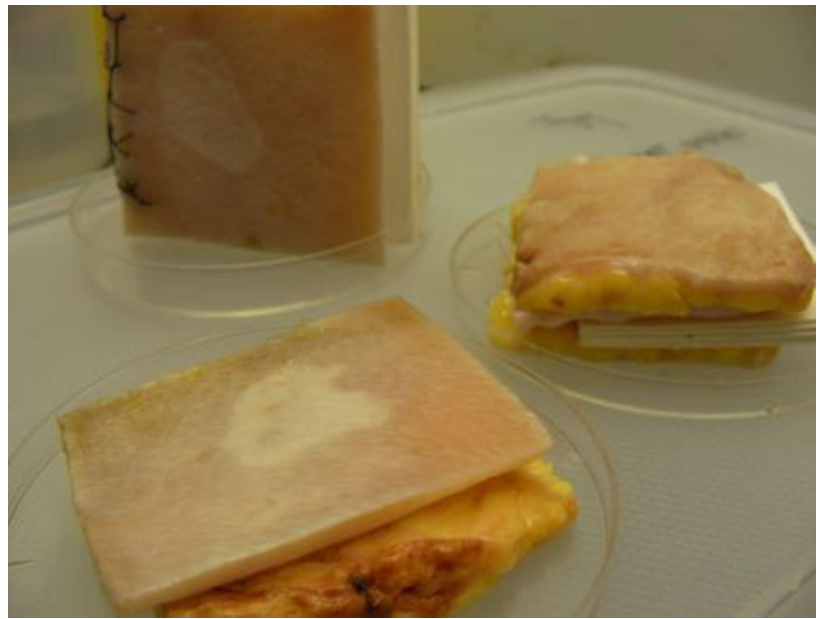

Tagny Duff, "Cryobooks".

Detalle de las impresiones de los sellos estampados

sobre las tapas de piel.

SymbioticA, UWA, Perth,

Australia, 2009. Imagen

cryobookarchives. word press.com

Figura 54

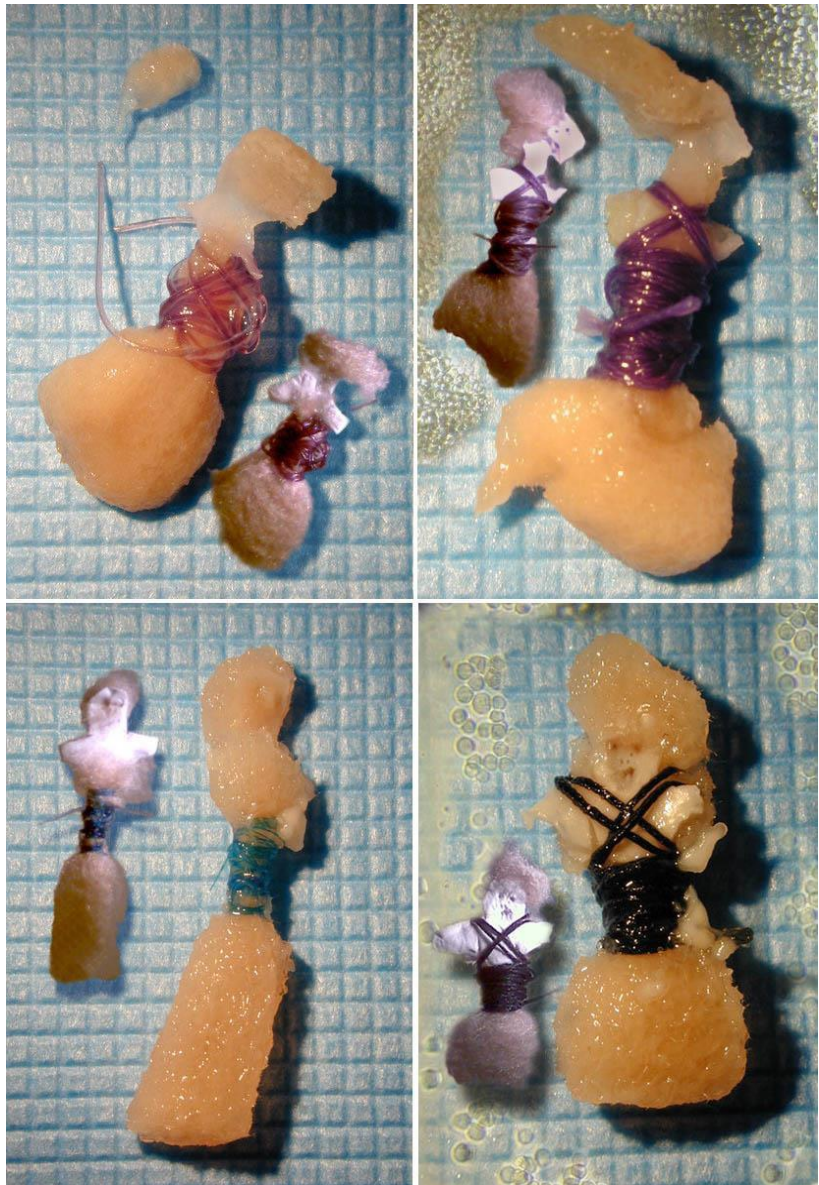

Tissue Culture \& Art

Project, "The Semi-Living

Worry Dolls". De izquierda a

derecha y de arriba abajo

muñecas: b, c, f y h. $2000 @$

TC\&A 
Figura 55
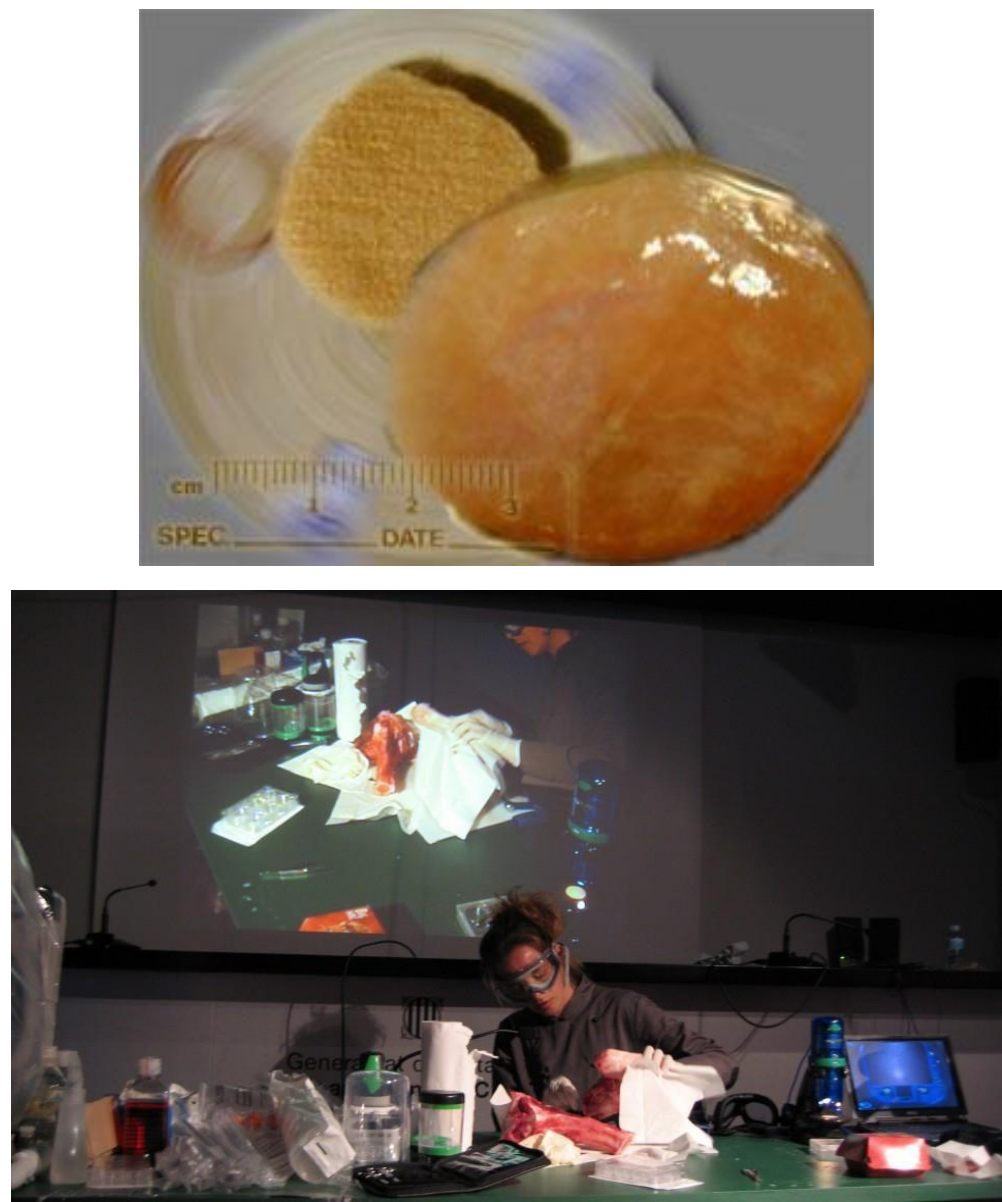

Figura 57

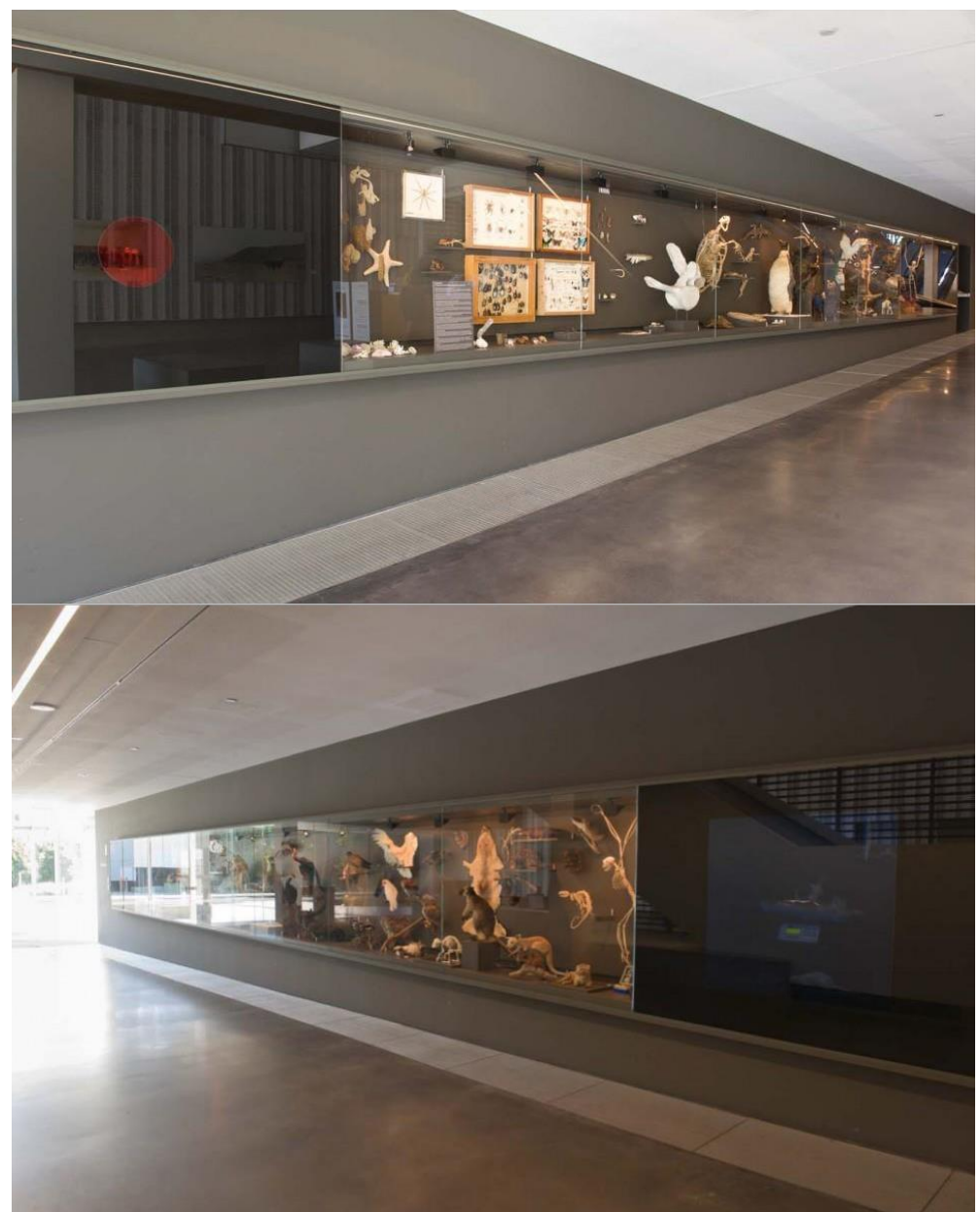

Tissue Culture \& Art

Project, "Disembodied

Cuisine". Estructura

polimérica y cultivo en forma

de filete semi-vivo. 2003 ( $)$

TC\&A

Tissue Culture \& Art Project, "The DIY De-

victimizer Kit Mark One (DVK m1)". Performance en Días de Bioarte, Centre d'Art

Santa Mònica, Barcelona España, 2006 @ TC\&A

Tissue Culture \& Art

Project, "Odd Neolifism". Instalación. Art in the First Decade, Gallery of Modern Art, Brisbane, Australia 2010 (c) TC\&A 


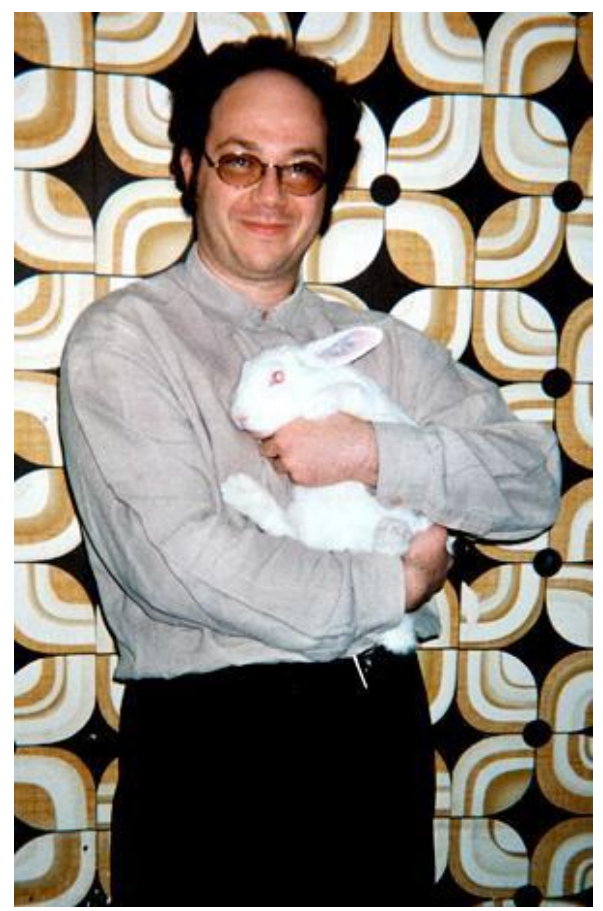

Figura 59

Figura 60
Eduardo Kac, "GFP Bunny". El artista sosteniendo en brazos a la coneja

transgénica Alba. Avignon, Francia, 2000. Fotografía de Chrystelle Fontaine

Eduardo Kac, "Genesis". En el centro la cápsula de Petri con la bacteria transgénica, a la derecha la cámara de microvideo, a la izquierda un microscopio iluminador debajo una caja de luz UV. Este conjunto está

conectado a un proyector $y$ dos computadoras en red que procesan imagen y sonido. O.K. Center for Contemporary Art, Linz, Austria, 1999. Fotografía Otto Saxinger
Eduardo Kac, "Move 36". Detalle de la planta

transgénica ubicada en e tablero de ajedrez. 2004. 
Figura 61
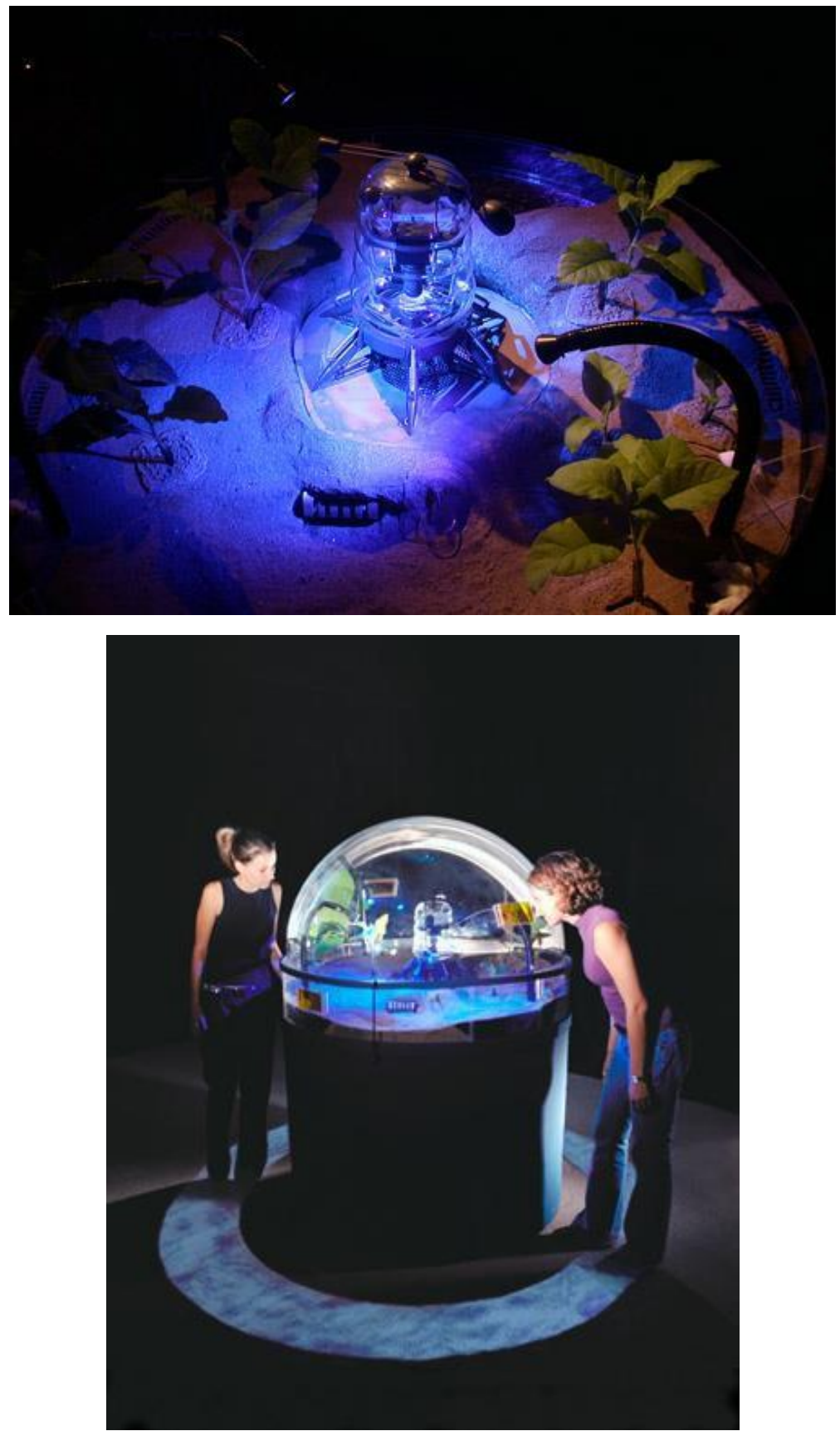

Figura 62

a Fle Edit View Go Favorites Tools Window Help $1150 \mathrm{AM} / \mathrm{B} / \mathrm{P}$

Figura 63

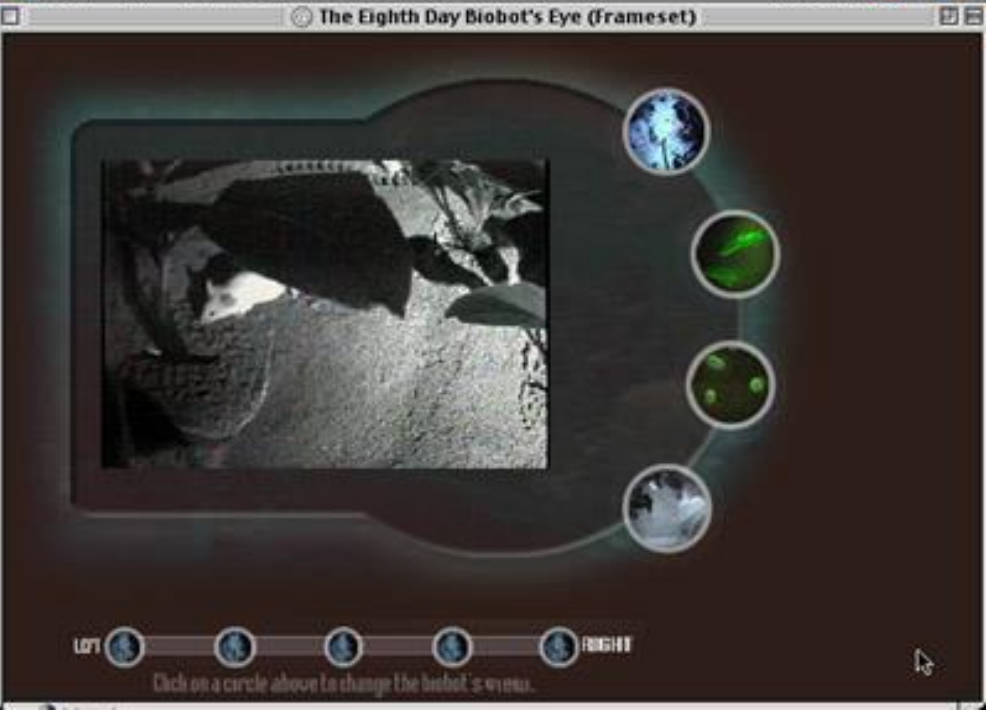

Eduardo Kac, "The Eighth Day". Vista del ecosistema de criaturas transgénicas: plantas, ratones, peces, $y$ amebas en el interior del biobot. Institute for Studies in the Arts, Arizona State University, Tempe, Estados Unidos, 2001. Fotografía

Eduardo Kac
Eduardo Kac, "The Eighth Day". Espectadores

observando desde fuera del terrario. Institute for Studies in the Arts, Arizona State University, Tempe, Estados Unidos, 2001. Fotografía Camera Werks
Eduardo Kac, "The Eighth Day". Captura de pantalla donde se puede observar el punto de vista del biobot transmitiendo a través de internet, 2001. 
Figura 64

Figura 65

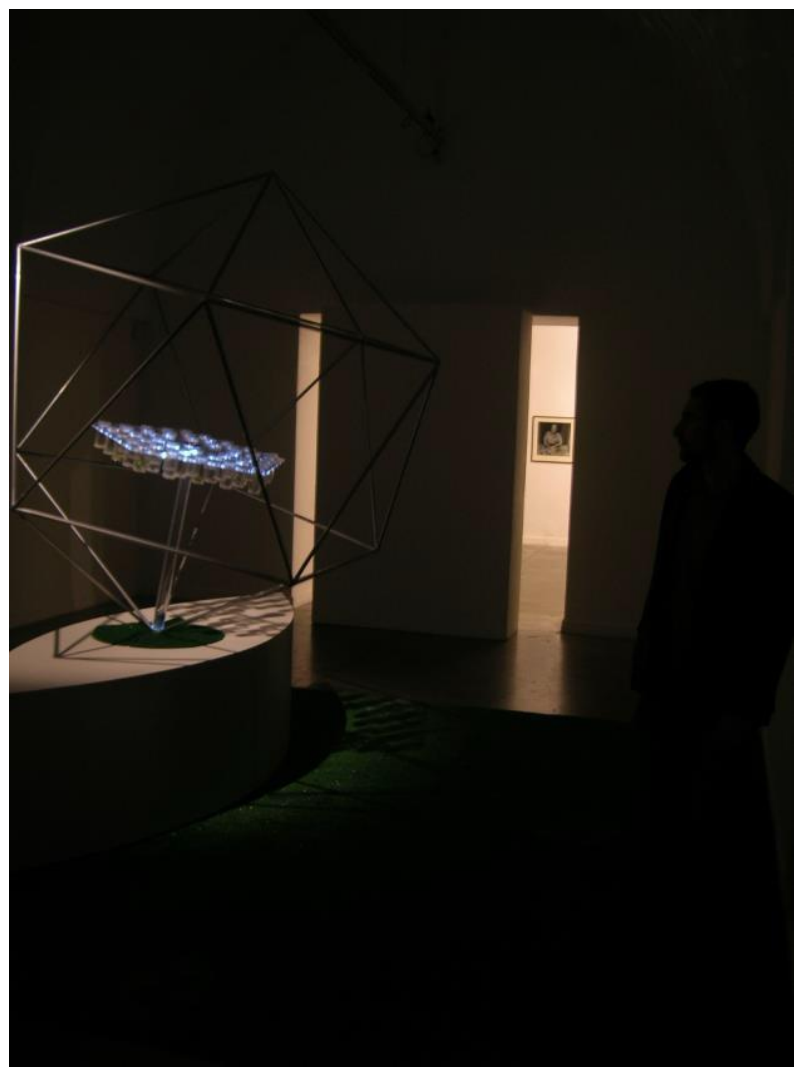

Proyecto Untitled

"Incubaedro". Vista de la

instalación robótica.

Naturaleza Intervenida,

Centro Cultural Recoleta,

Buenos Aires, Argentina,

2008. Fotografía Martín

Alterisio.

Proyecto Untitled

"Incubaedro". Detalle de las orquídeas en el sustrato.

Inauguración del Laboratorio de Bioarte, Universidad

Maimónides, Buenos Aires,

Argentina, 2008. Fotografía Natalia Matewecki.

Figura 66

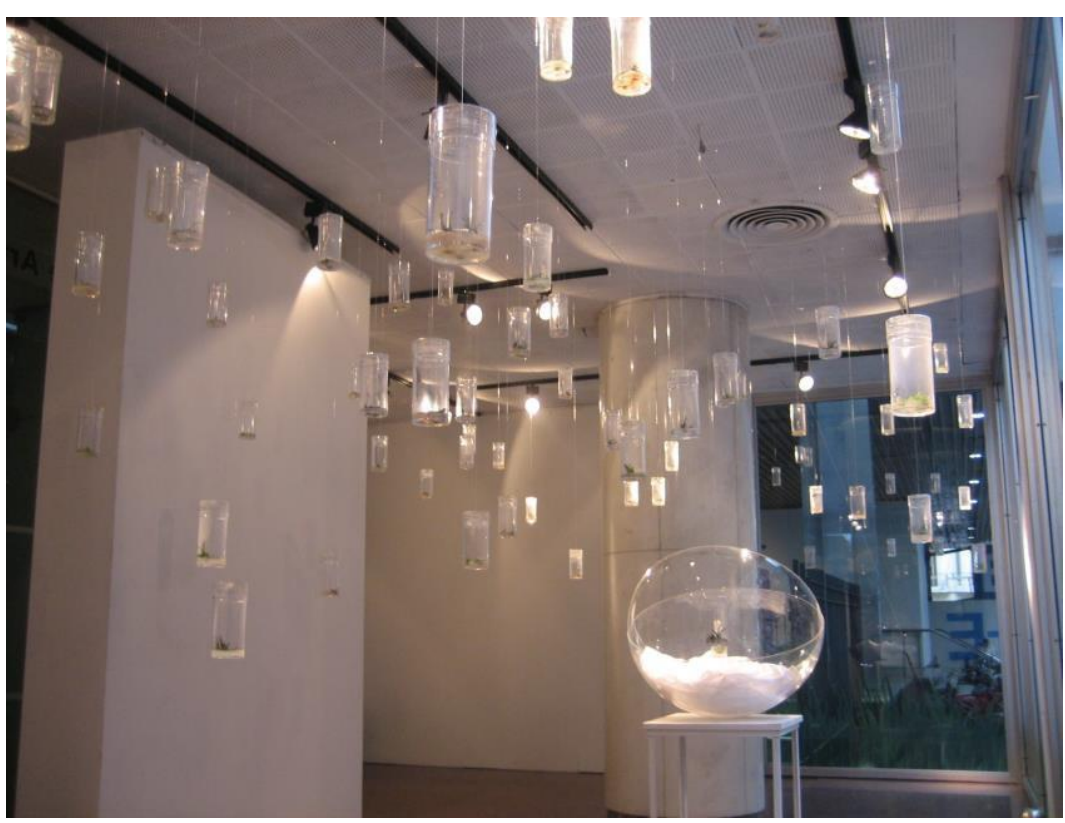

Proyecto Untitled

"Invernadero Lúdico". Vista general de la instalación interactiva. Cultura y Media, Centro Cultural General San Martín, Buenos Aires,

Argentina, 2008. Fotografía gentileza de Romina Flores. 
Figura 67

Figura 68

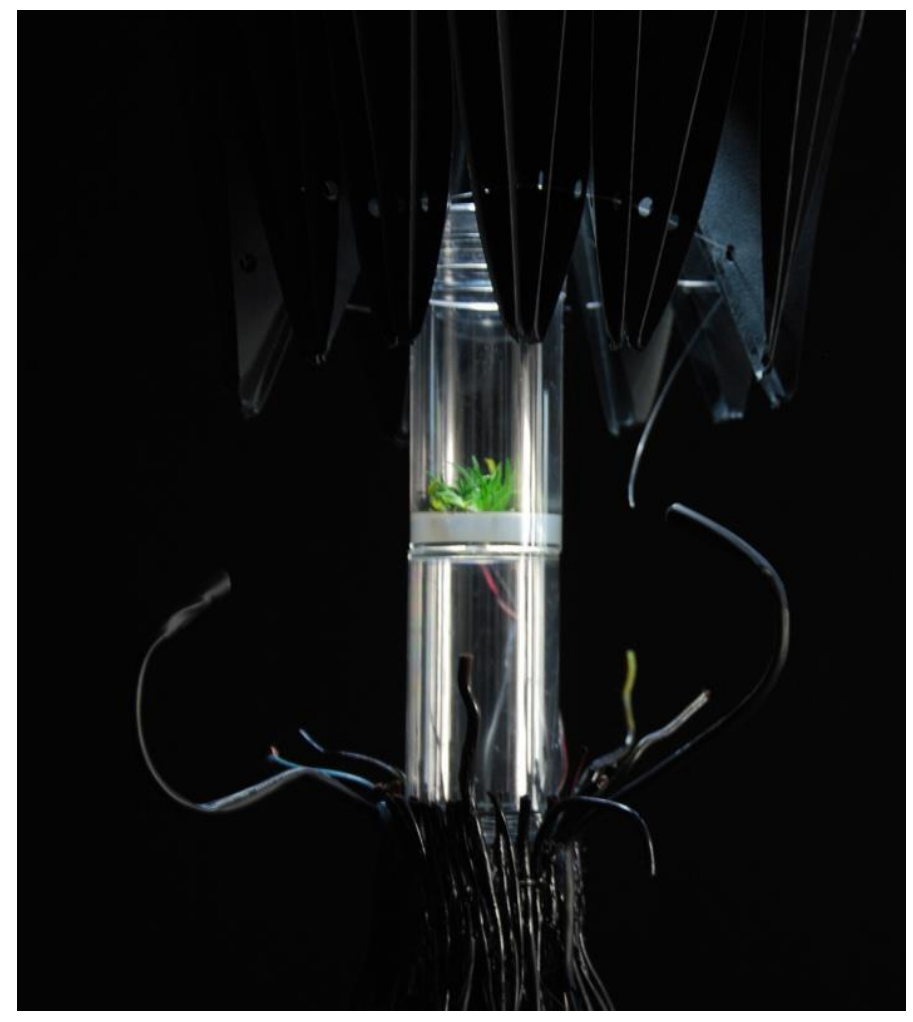

Proyecto Untitled, "Edenia". Detalle de la orquídea fecundada in vitro. Cultura y

Media, Centro Cultural

General San Martín, Buenos Aires, Argentina, 2010. @

Multimedia Maimónides.

Proyecto Untitled, "Late". Videoinstalación interactiva, capturas de video.

Extinciones, Centro Cultural

Recoleta, Buenos Aires,

Argentina, 2010. 
Figura 69

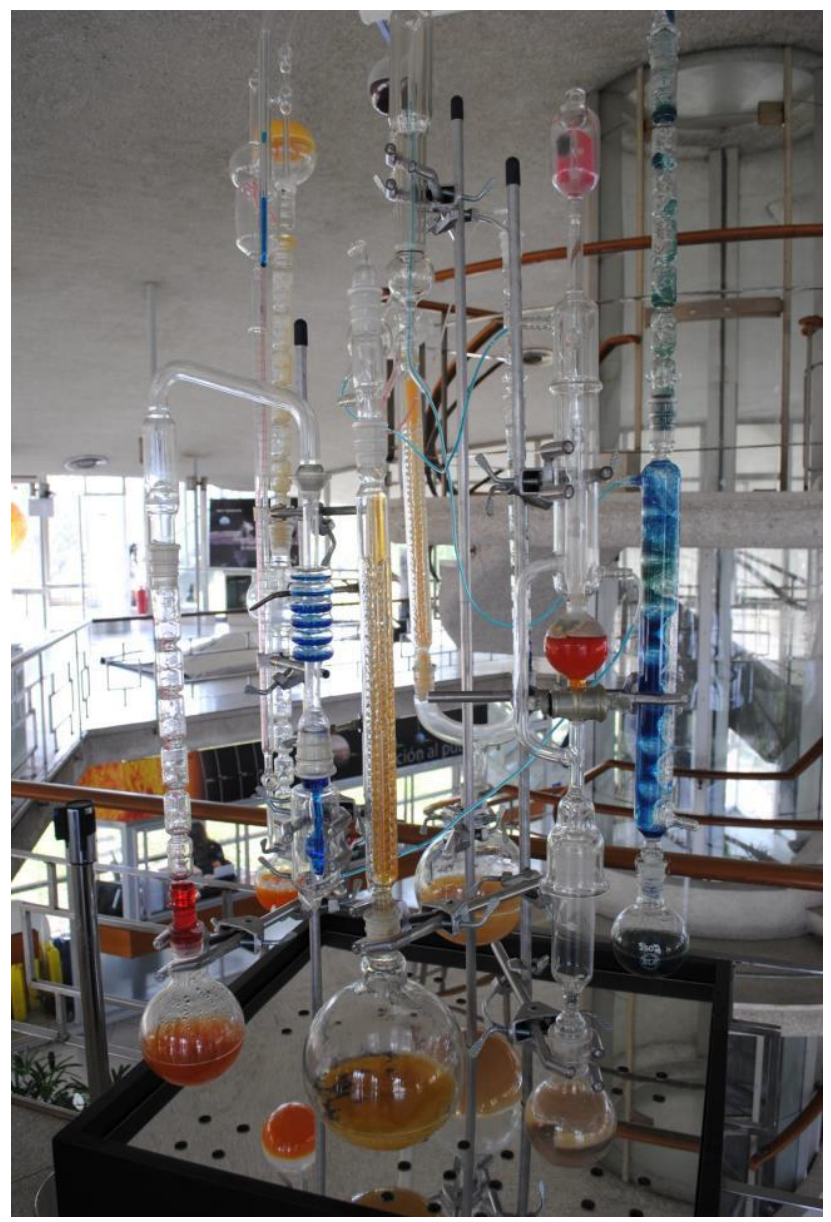

Proyecto Untitled, ".a

priori". Vista de la instalación con los balones, tubos

refrigerantes y embudos que contienen a la población de bacterias creciendo en sustratos de diferentes colores. 2da Bienal Kosice, Planetario de la Ciudad, Buenos Aires, Argentina, 2012. Fotografía gentileza de Romina Flores.

Figura 70

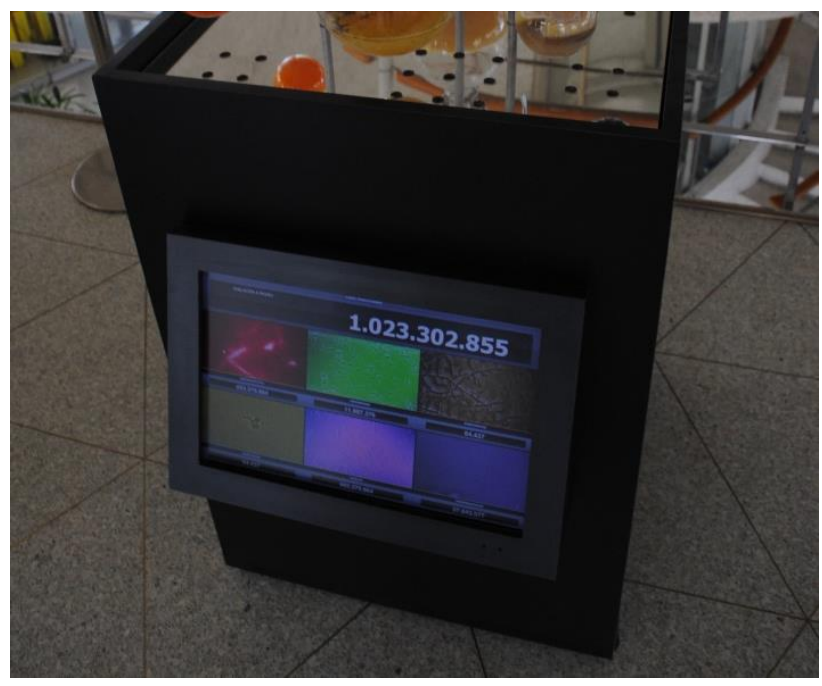

Figura 71

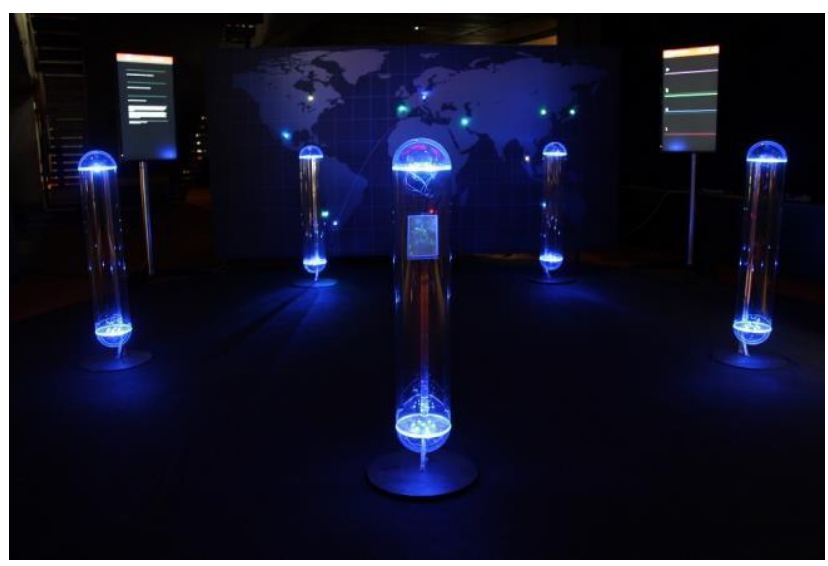

Proyecto Untitled, ".a

priori". Vista del contador de población bacteriana. $2 d a$ Bienal Kosice, Planetario de la Ciudad, Buenos Aires, Argentina, 2012. Fotografía gentileza de Romina Flores.

Joaquín Fargas, "Big Brain Project". Instalación interactiva en la que se conjugan procesos biológicos con medios tecnológicos de transmisión de información. Ars Electronica, Linz, Austria,

2013. Imagen

joaquinfargas.com.ar 
Figura 72
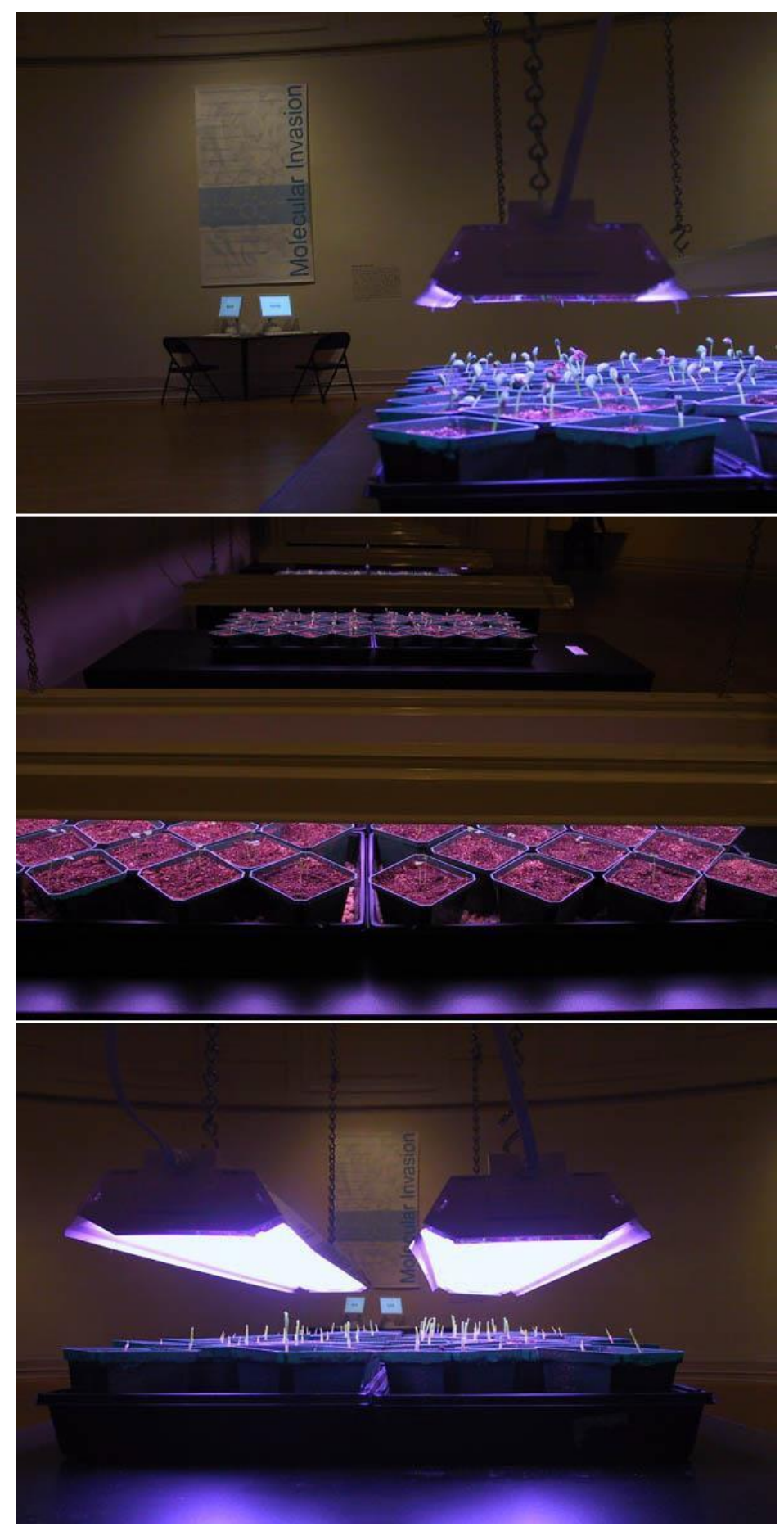

Critical Art Ensemble

"Contestational Biology".

Roundup Ready canola

(arriba), Roundup Ready soja (centro), Roundup

Ready maiz (abajo).

Corcoran Art Gallery,

Washington DC, Estados

Unidos, 2002. Imagen

www.critical-art.net

Figura 73

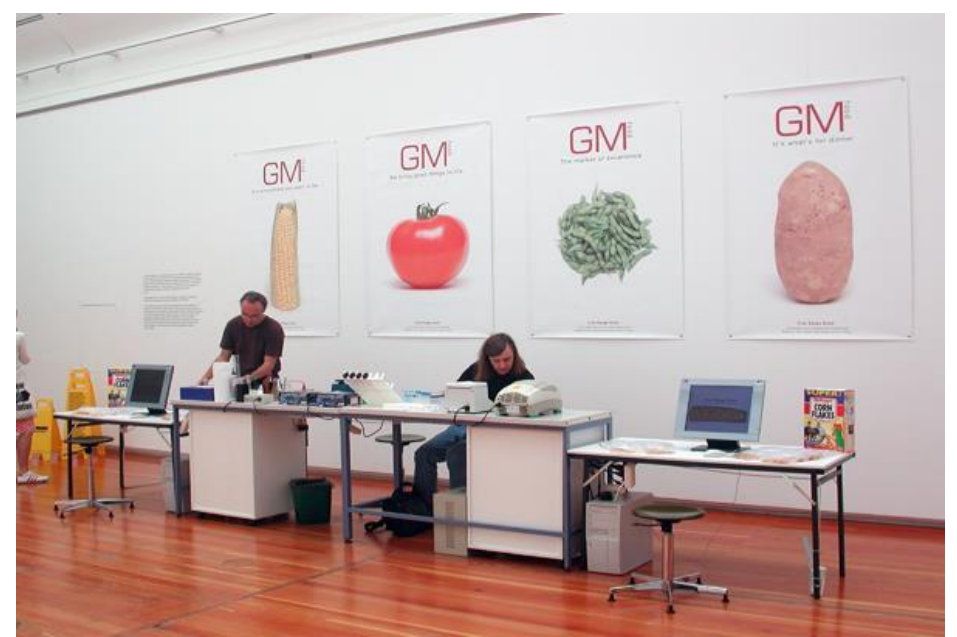

Critical Art Ensemble,

"Free Range Grain". Vista

del laboratorio montado en Schirn Kunsthalle, Frankfurt

Alemania, 2003. Imagen www.critical-art.net 
Figura 74

Figura 75

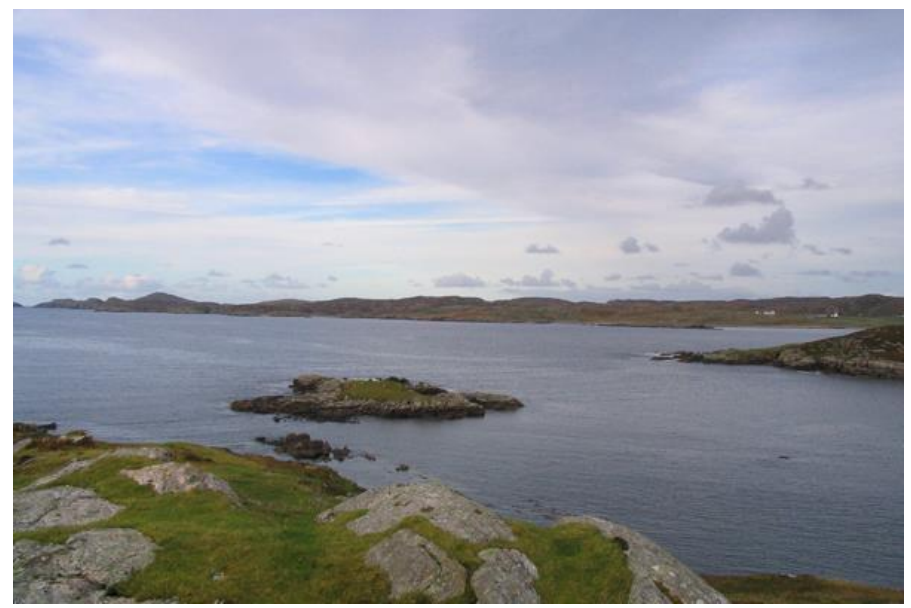

Critical Art Ensemble

"Marching Plague". Isla de Lewis, Escocia, 2005

Imagen www.critical-art.net

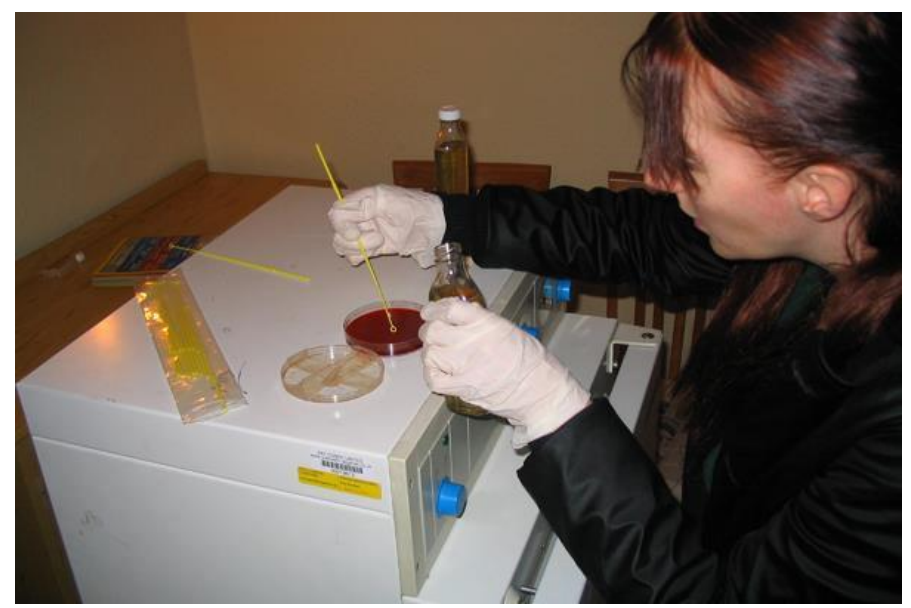

Critical Art Ensemble,

"Marching Plague". Miembro del CAE preparando el caldo bacteriano, 2005. Imagen www.critical-art.net

Figura 76

Figura 77

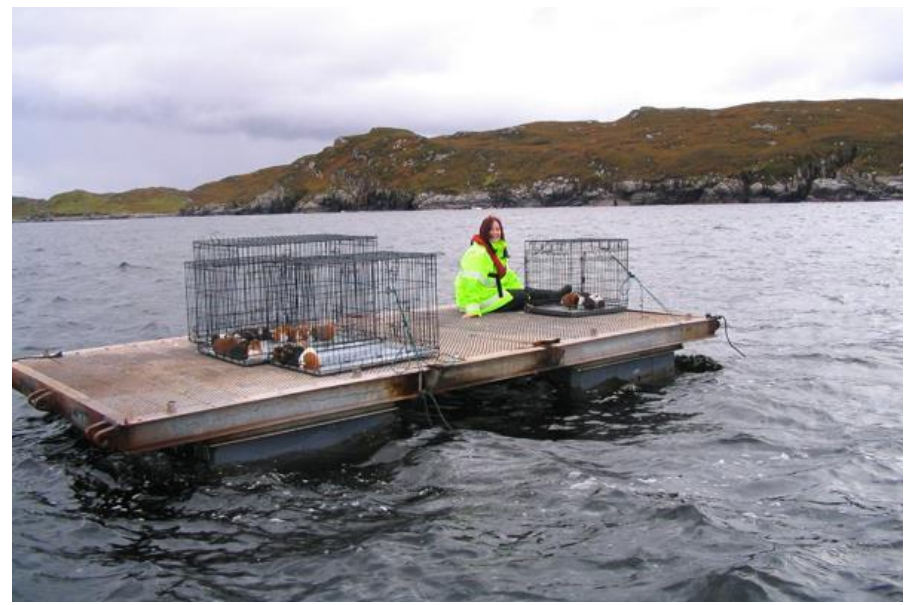

Critical Art Ensemble

"Marching Plague". Los cobayos y un supervisor de

la Sociedad para la

Prevención de la Crueldad a los Animales subidos a una plataforma de flotación en medio de la bahía, 2005.

Imagen www.critical-art.net

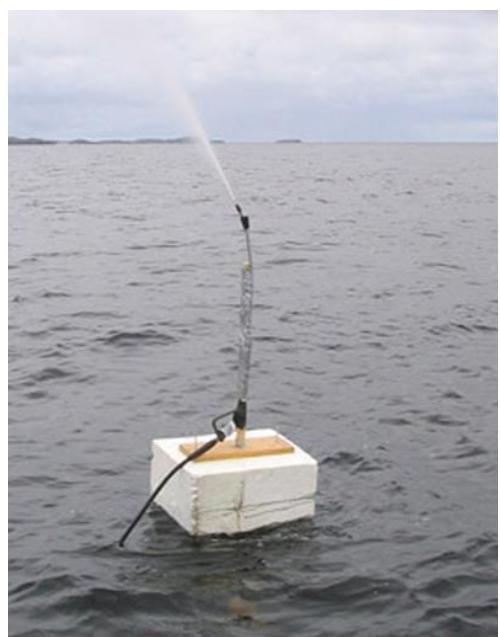

Critical Art Ensemble

"Marching Plague". El caldo bacteriano se lanza con un dispositivo de pulverización a presión desde la parte posterior de la embarcación 2005. Imagen www.criticalart.net 
Figura 78

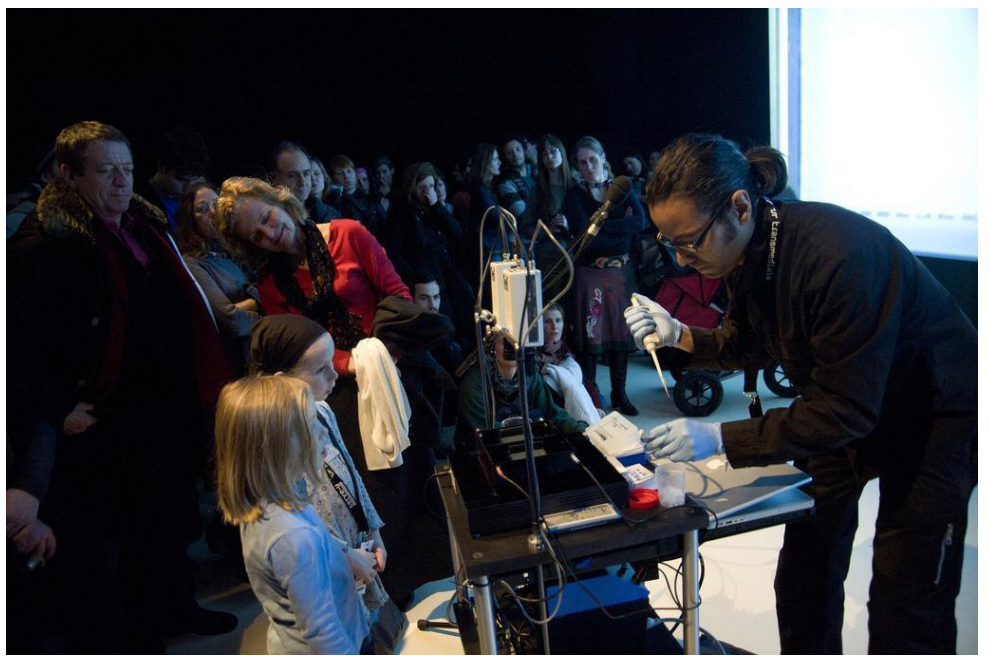

Paul Vanouse, "Latent

Figure Protocol".

Performance en la muestra

Transmediale, Haus der

Kulturen der Welt, Berlin, Alemania, 2011. Imagen www.paulvanouse.com

Figura 79

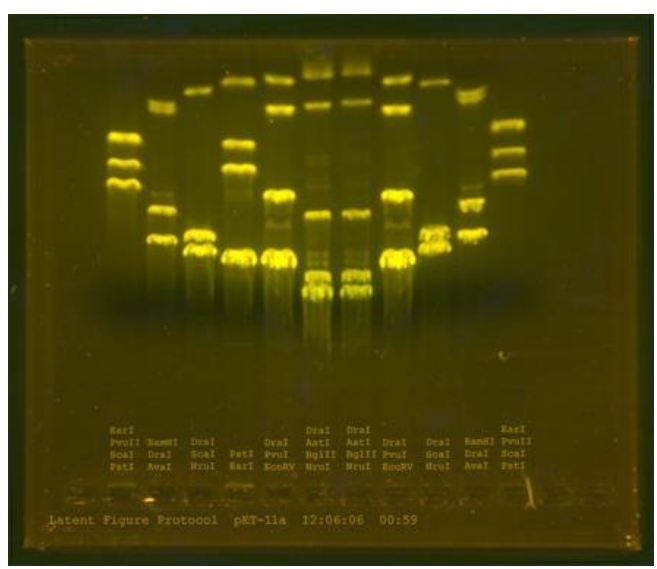

Paul Vanouse, "Laten

Figure Protocol". La figura fue producida con el ADN de plásmido bacteriano $\mathrm{pET}$ 11a. Las enzimas usadas para procesar el ADN se enumeran en cada columna, 2006. Imagen

www. paulvanouse.com

Figura 80

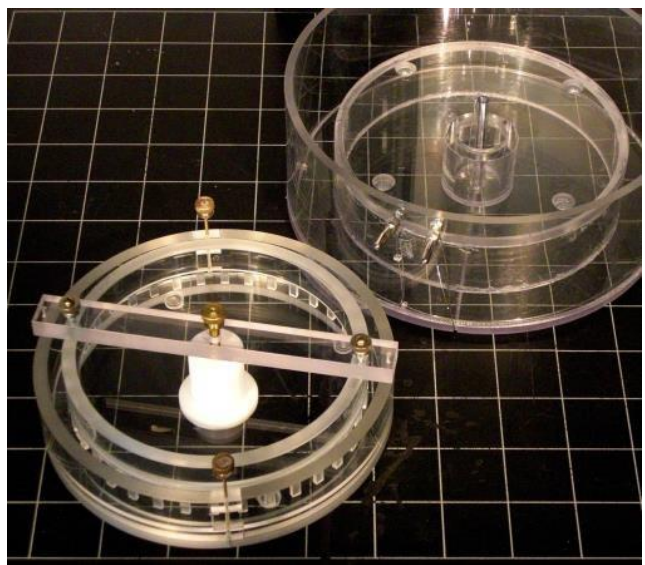

Paul Vanouse, "Ocular Revision"Anillos para electroforesis especialmente diseñados para la obra. Imagen

www.paulvanouse.com

Figura 81

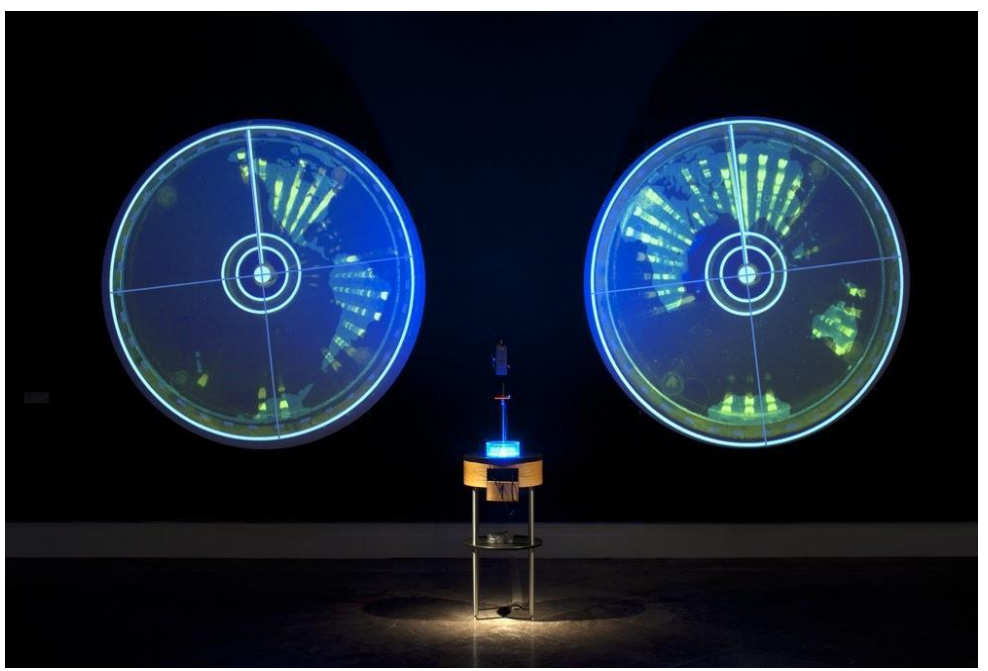

Paul Vanouse, "Ocular Revision". Vista de la instalación con el gabinete circular que contiene el anillo de electroforesis, la cámara, la fuente de alimentación y el transiluminador de luz azul. Albright-Knox Art Gallery, Buffalo, Estados Unidos, 2011. Fotografía Tom Loonan. 
Figura 82

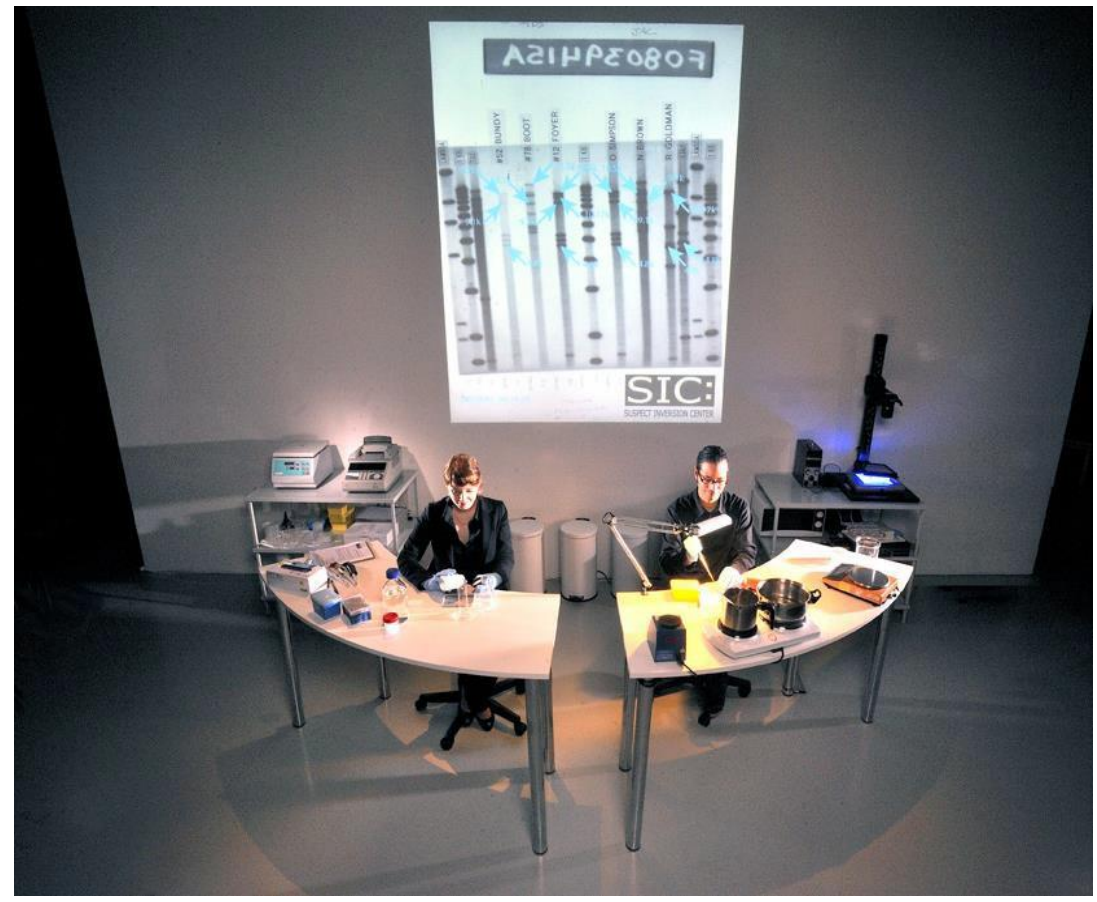

Paul Vanouse, "Suspect

Inversion Center".

Performance de Paul

Vanouse y Kerry Sheehan.

Ernst Schering Foundation,

Berlin, Alemania, 2011.

Fotografía Axel Heise

Figura 83

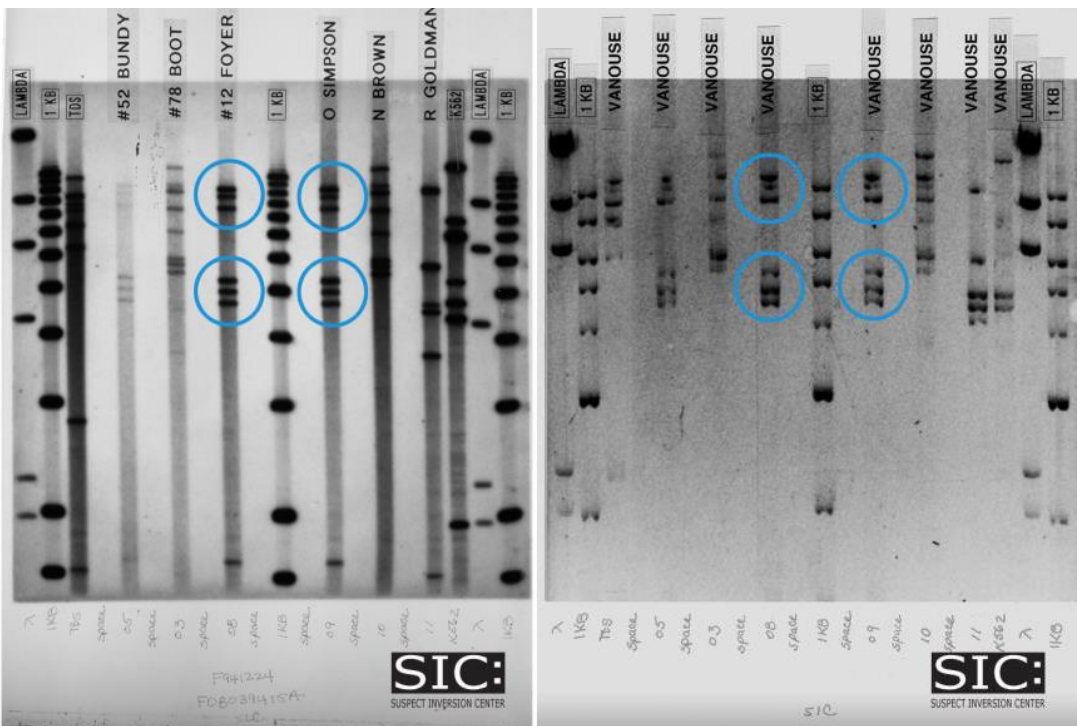

Paul Vanouse, "Suspect

Inversion Center". A la

izquierda imagen del análisis de ADN de O.J. Simpson, a la derecha imagen producida a partir del análisis de ADN

del artista. Imagen

www.paulvanouse.com

Figura 84

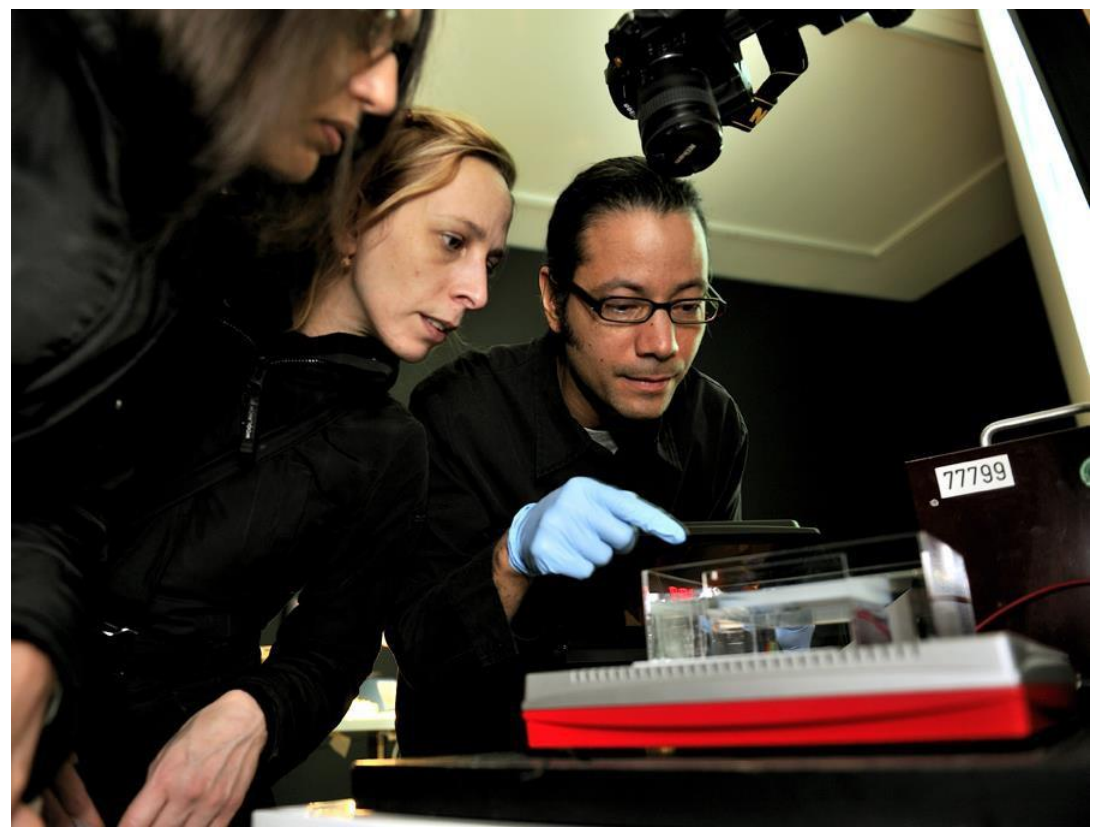

Paul Vanouse, "Suspect Inversion Center". El artista explicando a los espectadores el

procedimiento de

electroforesis en gel. Ernst Schering Foundation, Berlin, Alemania, 2011. Fotografía Axel Heise 
Figura 85

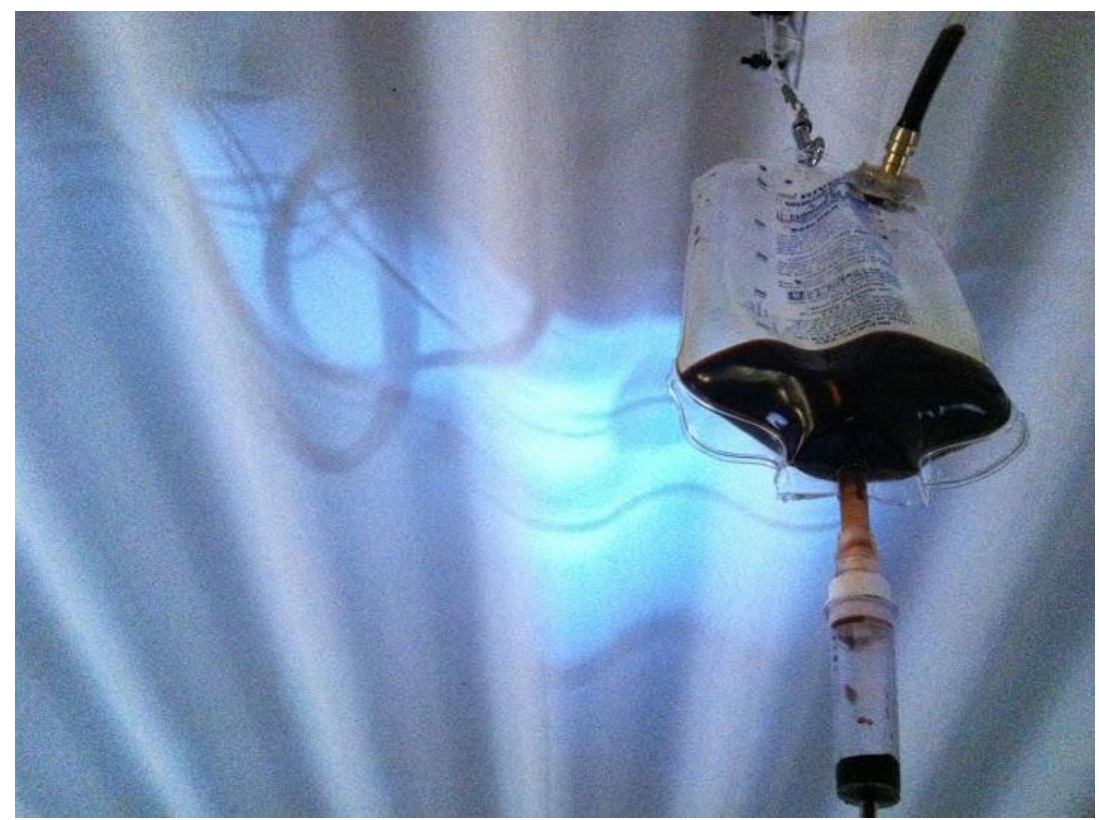

Grupo@Agua_Y_Aceite,

"Generación de conciencia

I". Envase de suero

fisiológico relleno de líquido

coloreado que alimenta a los microorganismos. MediaLAB

Proyectos 2011, CCEBA

Buenos Aires, Argentina,

2011. (c) Agua_Y_Aceite

Proyecto

Figura 86

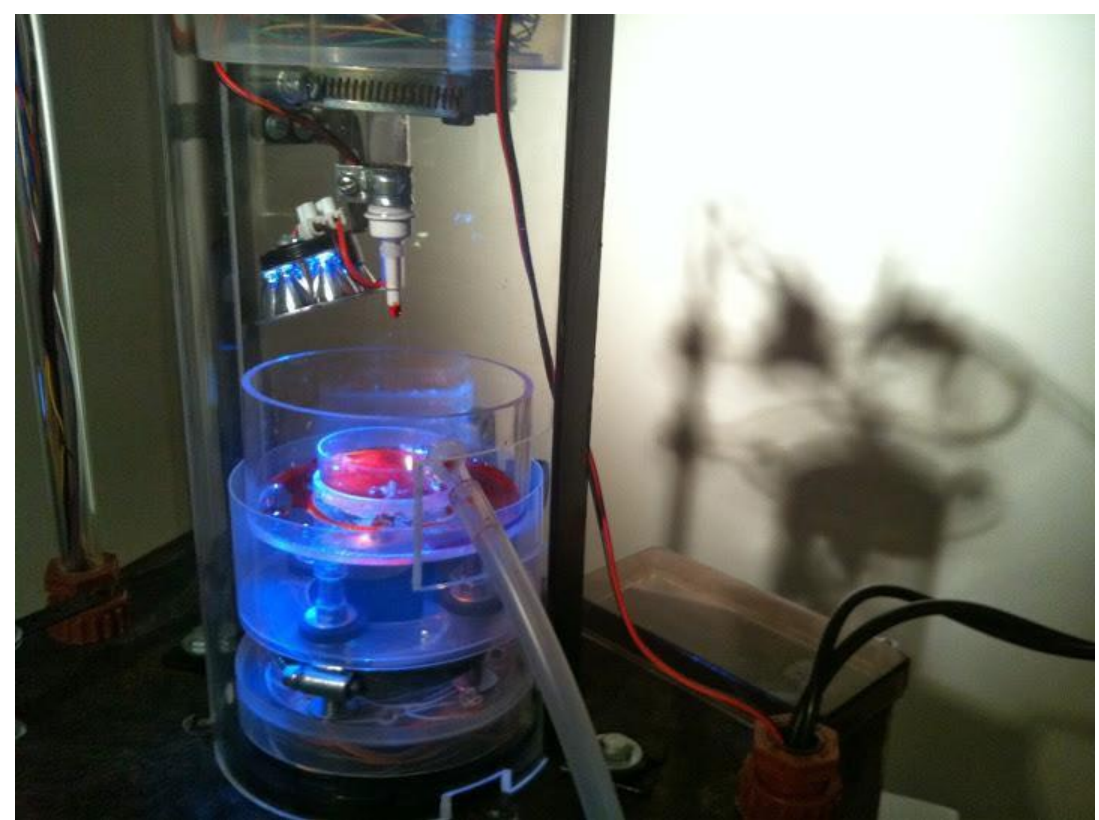

Grupo@Agua_Y_Aceite,

"Generación de conciencia

I". Detalle del sistema de goteo. MediaLAB Proyectos

2011, CCEBA, Buenos

Aires, Argentina, 2011. @

Agua_Y_Aceite Proyecto

Figura 87

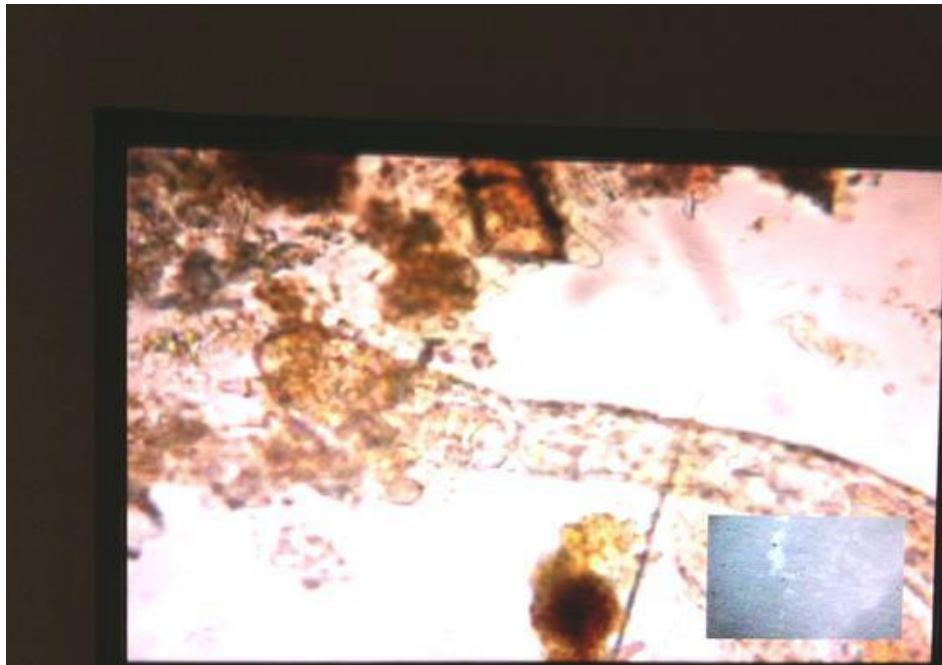

Grupo@Agua_Y_Aceite,

"Generación de conciencia

I". Visualización de los

microorganismos. MediaLAB

Proyectos 2011, CCEBA,

Buenos Aires, Argentina,

2011. @ Agua_Y_Aceite

Proyecto 


\begin{tabular}{|c|c|c|c|c|c|c|c|c|}
\hline \multirow{26}{*}{ Figura 88} & \multicolumn{8}{|c|}{ Tasa de mortalidad por mil habitantes, según grupo de edad y sexo. Total de pais. Anos 1980/2007 } \\
\hline & \multirow[b]{2}{*}{ Grupo de edad y sexo } & \multicolumn{7}{|c|}{ Alas } \\
\hline & & 1980 & 1990 & 2000 & $\begin{array}{r}2004 \\
0000\end{array}$ & 2005 & 2006 & 2007 \\
\hline & $\begin{array}{l}\text { Total del pais } \\
\text { Varones }\end{array}$ & $\begin{array}{r}8,6 \\
10,0 \\
73\end{array}$ & $\begin{array}{l}8,0 \\
8,9\end{array}$ & $\begin{array}{l}7,5 \\
8,3\end{array}$ & $\begin{array}{l}7,7 \\
8,3 \\
7,3\end{array}$ & $\begin{array}{l}7,6 \\
8.2 \\
70\end{array}$ & $\begin{array}{l}7,5 \\
8,1\end{array}$ & $\begin{array}{l}8,0 \\
8,6 \\
7,5\end{array}$ \\
\hline & Mujeress & & & & & & & \\
\hline & Menores do 1 afto & 33,2 & 25,6 & 16,6 & 14,4 & 13,3 & 12,9 & 13,3 \\
\hline & \begin{tabular}{|l|} 
Varones \\
Mujeres
\end{tabular} & $\begin{array}{l}36,7 \\
29,6\end{array}$ & $\begin{array}{l}28,2 \\
22,8\end{array}$ & $\begin{array}{l}18,3 \\
14,7\end{array}$ & $\begin{array}{l}15,7 \\
12,9\end{array}$ & $\begin{array}{l}14,8 \\
11,8\end{array}$ & $\begin{array}{l}14,1 \\
11,7\end{array}$ & $\begin{array}{l}14,4 \\
12,1\end{array}$ \\
\hline & $\begin{array}{l}1.4 \text { anos } \\
\text { Varones }\end{array}$ & $\begin{array}{l}1,5 \\
1,6\end{array}$ & $\begin{array}{l}1,1 \\
1,2\end{array}$ & $\begin{array}{l}0,7 \\
0,7\end{array}$ & $\begin{array}{l}0,6 \\
0,7 \\
0,5\end{array}$ & $\begin{array}{l}0.6 \\
0.6\end{array}$ & $\begin{array}{l}0,6 \\
0,6\end{array}$ & $\begin{array}{l}0,6 \\
0.6\end{array}$ \\
\hline & Mujeres & 1,5 & 1,0 & 0,6 & 0,6 & 0.6 & 0,5 & 0.6 \\
\hline & $\begin{array}{c}\text { 5a } 14 \text { años } \\
\text { Yarones } \\
\text { Majures }\end{array}$ & $\begin{array}{l}0,5 \\
0,5 \\
0.4\end{array}$ & $\begin{array}{l}0,3 \\
0,4 \\
0,3\end{array}$ & $\begin{array}{l}0,3 \\
0,3 \\
0,2\end{array}$ & $\begin{array}{l}0,3 \\
0,3 \\
0,2\end{array}$ & $\begin{array}{l}0,3 \\
0,3 \\
0.2\end{array}$ & $\begin{array}{l}0,3 \\
0,3 \\
0.2\end{array}$ & $\begin{array}{l}0,3 \\
0,3 \\
0.2\end{array}$ \\
\hline & 15 a 24 anos & 1,0 & 0,9 & 0.9 & 0,8 & 0,8 & 0,8 & 0,8 \\
\hline & \begin{tabular}{|l} 
Varones \\
Mujeres
\end{tabular} & 0,7 & 0,6 & 0,4 & 0,4 & 0.5 & 0.5 & 0.5 \\
\hline & 25 a 34 años & 1,5 & 1,2 & 1,2 & 1,0 & 1,0 & 1,0 & 1,1 \\
\hline & Mujeres & 1.2 & 0,9 & 0,8 & 0,7 & 0.6 & 0,7 & 0,7 \\
\hline & 35 a 44 años & 3,1 & 2,5 & 2,2 & 1,9 & $\begin{array}{l}1,9 \\
2,4\end{array}$ & $\begin{array}{l}1,9 \\
24\end{array}$ & $\begin{array}{r}1,9 \\
25\end{array}$ \\
\hline & \begin{tabular}{|l} 
Varonoses \\
Mujeres
\end{tabular} & 2,3 & 1,8 & 1.6 & 1,5 & 1.4 & 1,4 & 1,4 \\
\hline & 45 a 54 anos & 7,1 & 6,0 & 5,2 & 4,9 & 4,8 & 4,7 & 4.8 \\
\hline & \begin{tabular}{|l} 
Varones \\
Mujeres
\end{tabular} & $\begin{array}{l}9,7 \\
4,6\end{array}$ & $\begin{array}{l}8,0 \\
3,9\end{array}$ & $\begin{array}{l}7.0 \\
3.8\end{array}$ & $\begin{array}{l}6,4 \\
3,5 \\
\end{array}$ & ${ }_{34}^{6.4}$ & $\begin{array}{l}6,2 \\
3,3 \\
\end{array}$ & $\begin{array}{l}6,3 \\
3.4\end{array}$ \\
\hline & 55 a 64 aกิos & 15.2 & 13.8 & 119 & 11,7 & 115 & 114 & 11.8 \\
\hline & Varones & $\begin{array}{l}73,2 \\
21,1\end{array}$ & 19,3 & 16,5 & 15,9 & 15,8 & 15,5 & 16,1 \\
\hline & Tujores & 9,8 & 8,7 & 8,6 & 7,8 & 7,5 & 7,7 & 7,8 \\
\hline & 65 ล 74 aก̃กร & 34,6 & 29,5 & 26,5 & 26,2 & 25,7 & 24,8 & 26,2 \\
\hline & \begin{tabular}{|l|l} 
Varones \\
Muieres
\end{tabular} & $\begin{array}{l}46,8 \\
24,6 \\
\end{array}$ & $\begin{array}{l}40,6 \\
20,4\end{array}$ & $\begin{array}{l}37,3 \\
23,4\end{array}$ & $\begin{array}{l}36,8 \\
18.0\end{array}$ & $\begin{array}{l}36,3 \\
17.4\end{array}$ & $\begin{array}{l}34,8 \\
170\end{array}$ & $\begin{array}{l}36,6 \\
180\end{array}$ \\
\hline & 75 ancos y mas & 102.8 & 100,8 & 91,5 & 91,6 & 90.0 & 88.0 & 95.4 \\
\hline & Varones & 120,8 & 117,5 & 109,6 & 108,7 & 106.5 & 104.5 & 113.0 \\
\hline & Mujeres & 91,0 & 88,9 & 81.1 & 81,9 & 80.6 & 78,7 & 85.4 \\
\hline
\end{tabular}

Figura 89

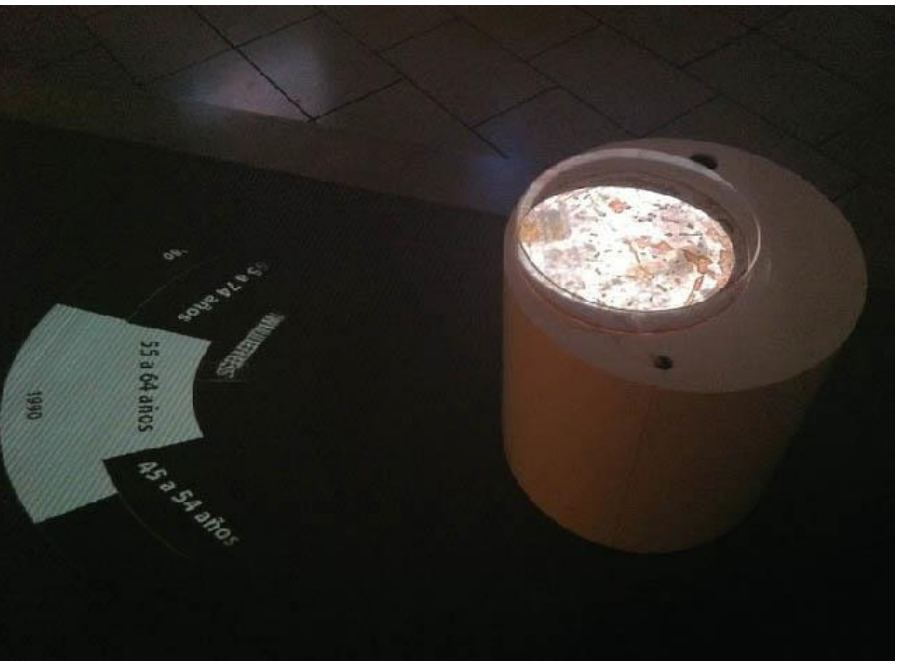

Grupo@Agua_Y_Aceite, "Generación de conciencia y II". Base de datos oficial utilizada en ambas obras, 2011

Grupo@Agua_Y_Aceite, "Generación de conciencia II". Detalle de la instalación MediaLAB Proyectos 2011, CCEBA, Buenos Aires, Argentina, 2011. () Agua_Y_Aceite Proyecto

Figura 90

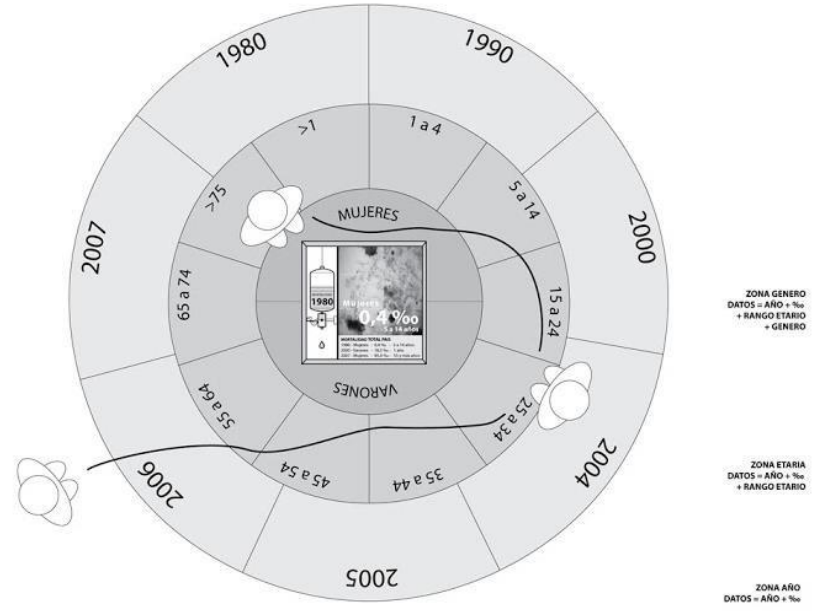

Grupo@Agua Y Aceite, "Generación de conciencia II". Diagrama del funcionamiento de la instalación. MediaLAB Proyectos 2011, CCEBA, Buenos Aires, Argentina, 2011. ( ) Agua_Y_Aceite Proyecto 
Figura 91

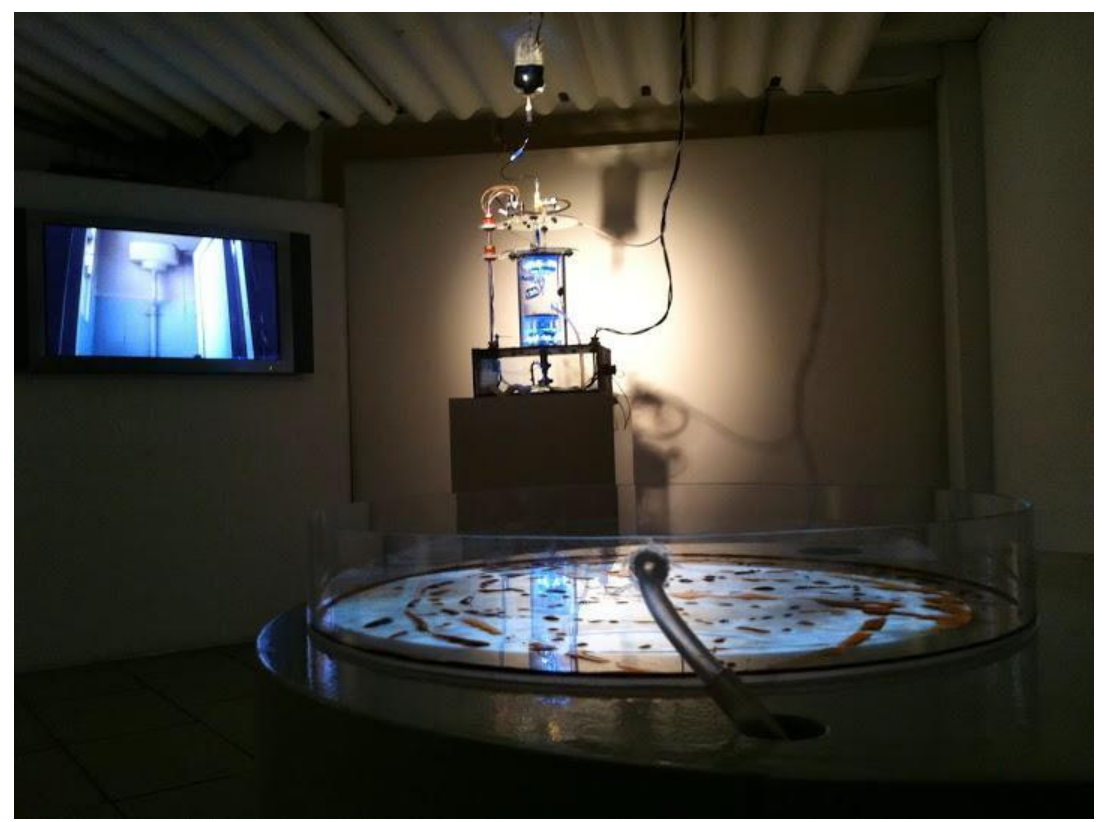

Grupo@Agua_Y_Aceite.

Vista general de las

instalaciones, detrás

"Generación de conciencia l"

y delante "Generación de

conciencia II". MediaLAB

Proyectos 2011, CCEBA,

Buenos Aires, Argentina,

2011. ( ) Agua_Y_Aceite

Proyecto

Verena Kaminiarz, "May the

mice bite me if it is not true".

El ratón Félix comiendo en el

sillón. SymbioticA, UWA,

Perth, Australia, 2008.

Imagen

www.verenakaminiarz.com

Figura 93

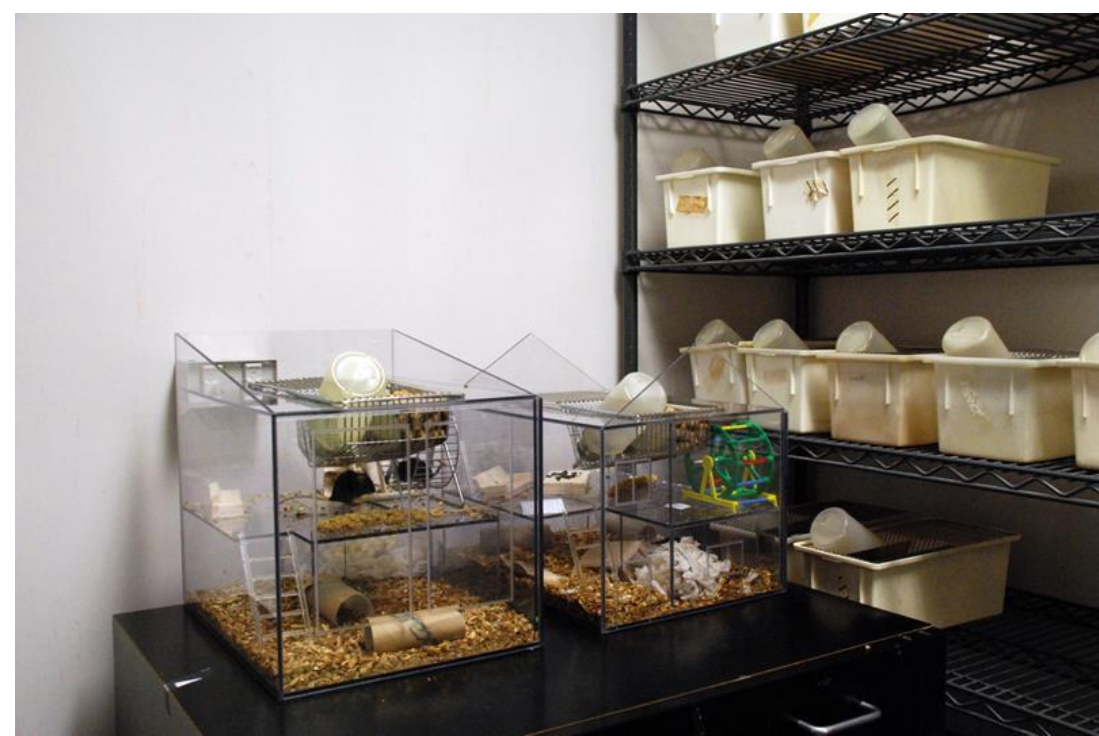

Verena Kaminiarz, "May the mice bite me if it is not true".

Detalle de las casas

construidas por la artista.

SymbioticA, UWA, Perth,

Australia, 2008. Imagen

www.verenakaminiarz.com 
Figura 94

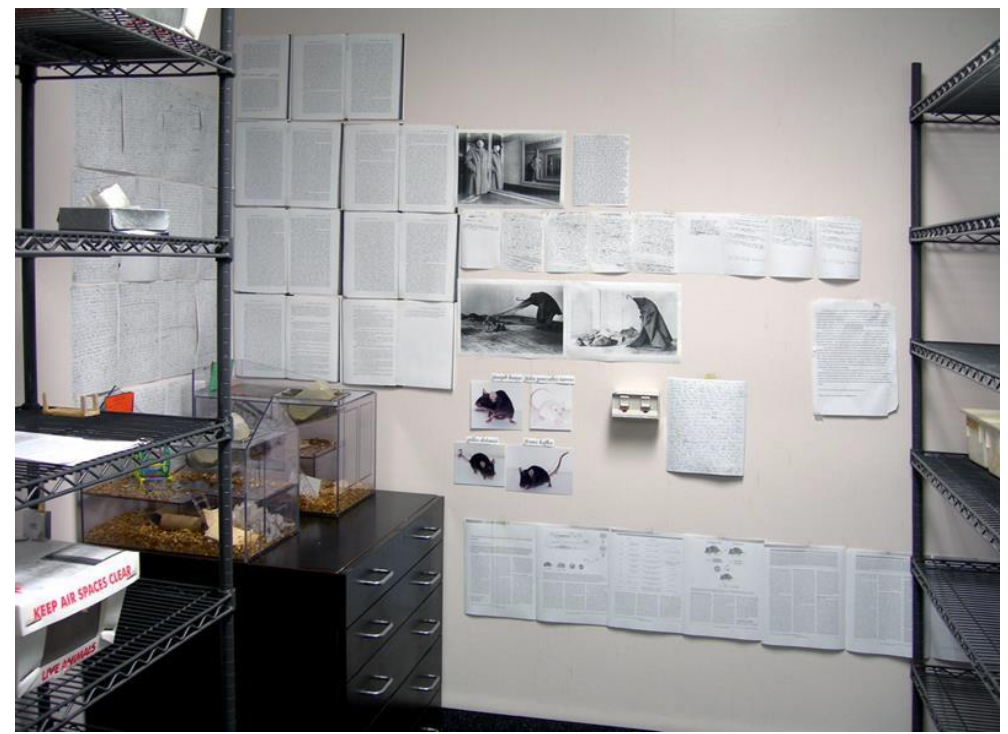

Figura 95

Figura 96

Figura 97
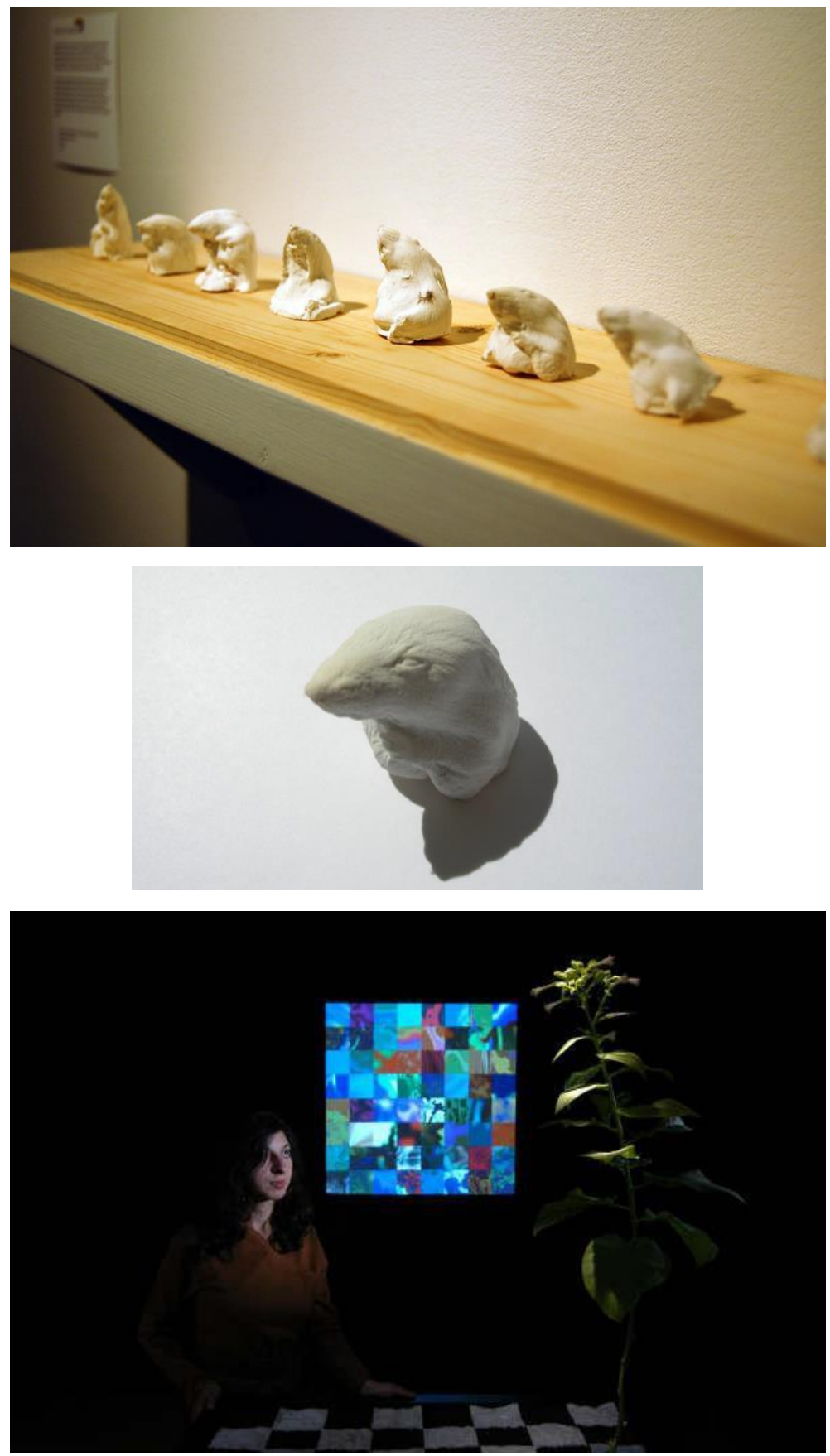

Verena Kaminiarz, "May the mice bite me if it is not true".

Imagen del laboratorio

donde vivían los ratones con

la documentación pegada en la pared. SymbioticA, UWA, Perth, Australia, 2008.

Imagen

www.verenakaminiarz.com

Verena Kaminiarz, "Death Masks (mus musculus)".

Imagen de la instalación. UWA, Perth, Australia, 2008. Imagen

www.verenakaminiarz.com

Verena Kaminiarz, "Death Masks (mus musculus)". Detalle de máscara mortuoria. UWA, Perth, Australia, 2008. Imagen www.verenakaminiarz.com

Eduardo Kac, "Move 36". Detalle de la instalación exhibida en la Galerie Biche de Bere, París, Francia, 2005. Imagen www.ekac.org 
Figura 98

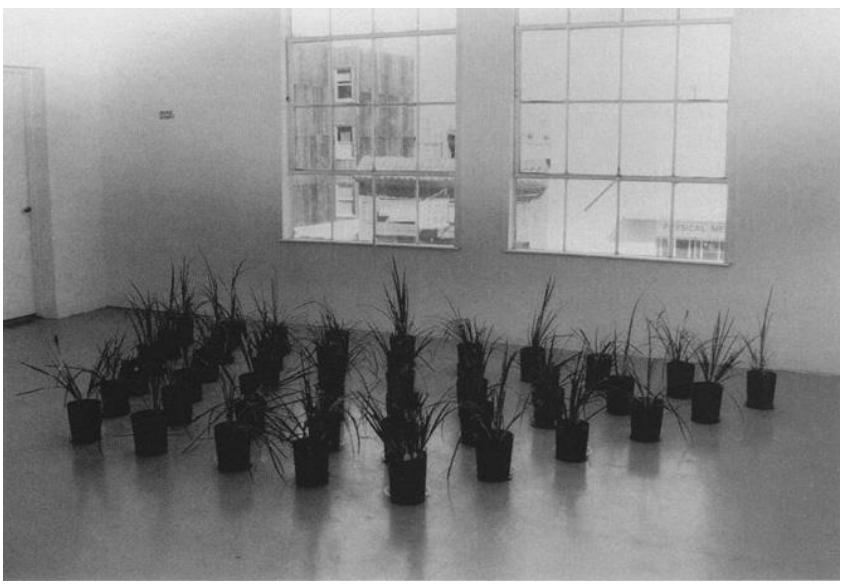

George Gessert, "Iris

Project". Instalación de plantas hibridadas para la muestra Post Nature. New Langton Arts, San Francisco, Estados Unidos, 1988.

Figura 99

Figura 100

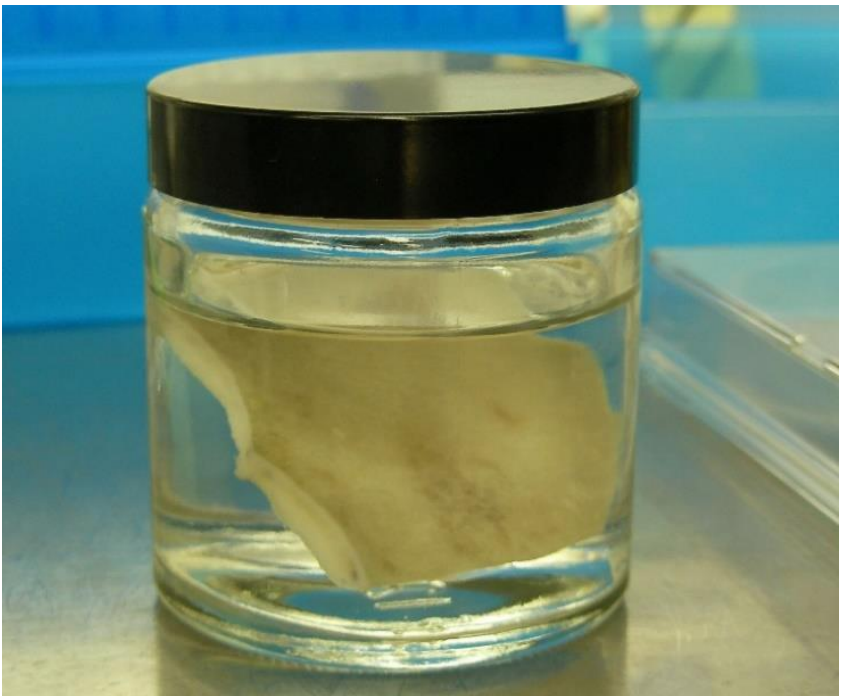

Tagny Duff, "Living Viral Tattoos". Frasco

conteniendo la piel de cerdo transfectada. SymbioticA,

UWA, Perth, Australia, 2008. Fotografia Tagny Duff (2)(1) $\$$

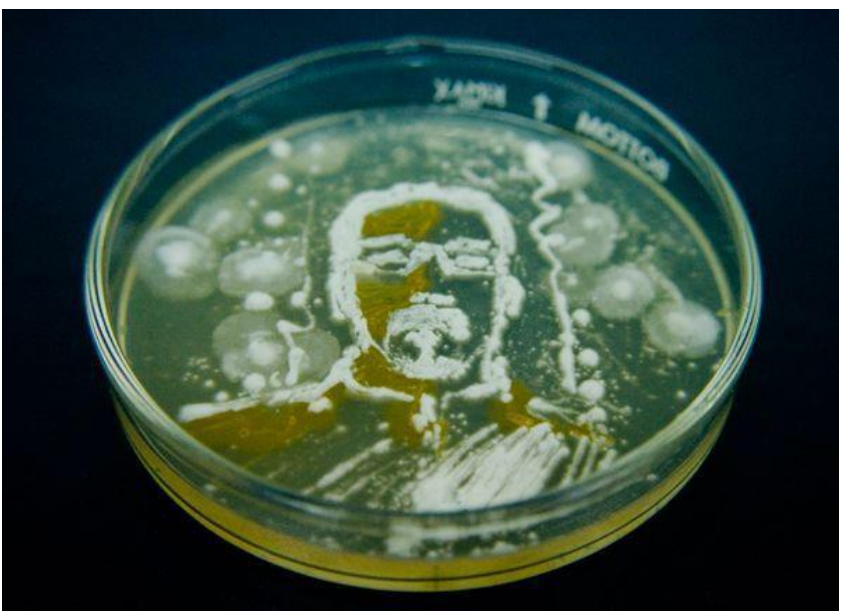

Allan Jeffs, "Ex-Sistencia". Autorretrato del artista realizado a partir del cultivo de levaduras, bacterias y hongos antárticos sobre placa de Petri. 2012.

Fotografía Allan Jeffs

Figura 101

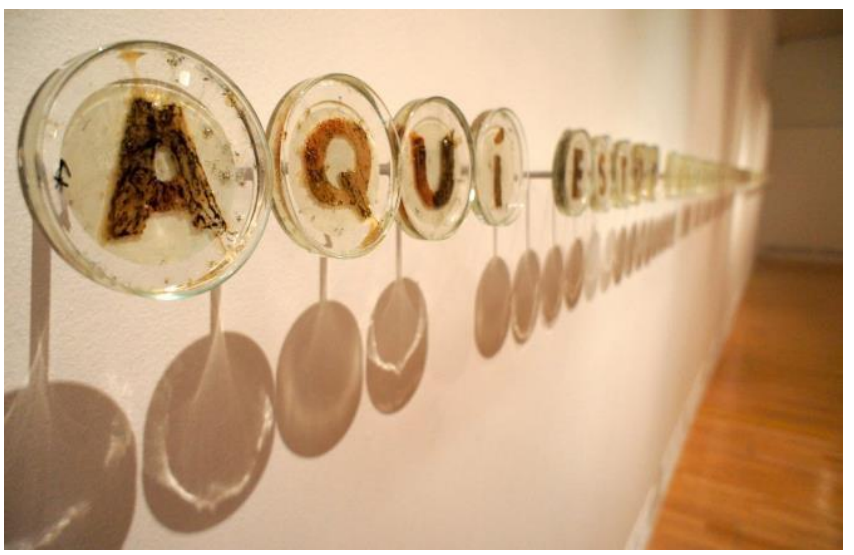

Allan Jeffs, "Ex-Sistencia". Detalle de la palabra "aquí" formada a partir de la flora bacteriana extraída de las manos de una tejedora Museo Antropológico de Arte Contemporáneo de

Guayaquil, Ecuador, 2012. Fotografía Rodolfo Kronfle 
Figura 103
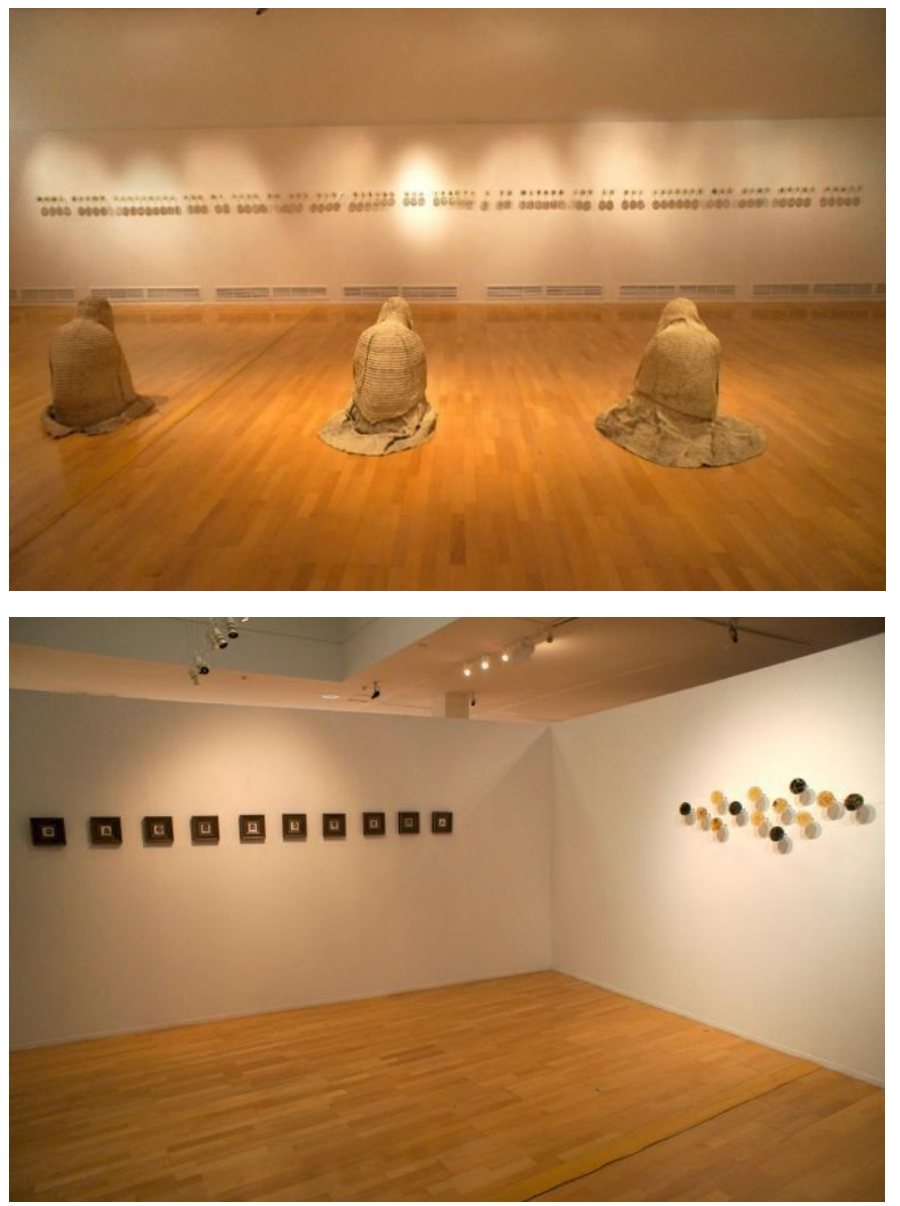

Figura 104

Figura 105
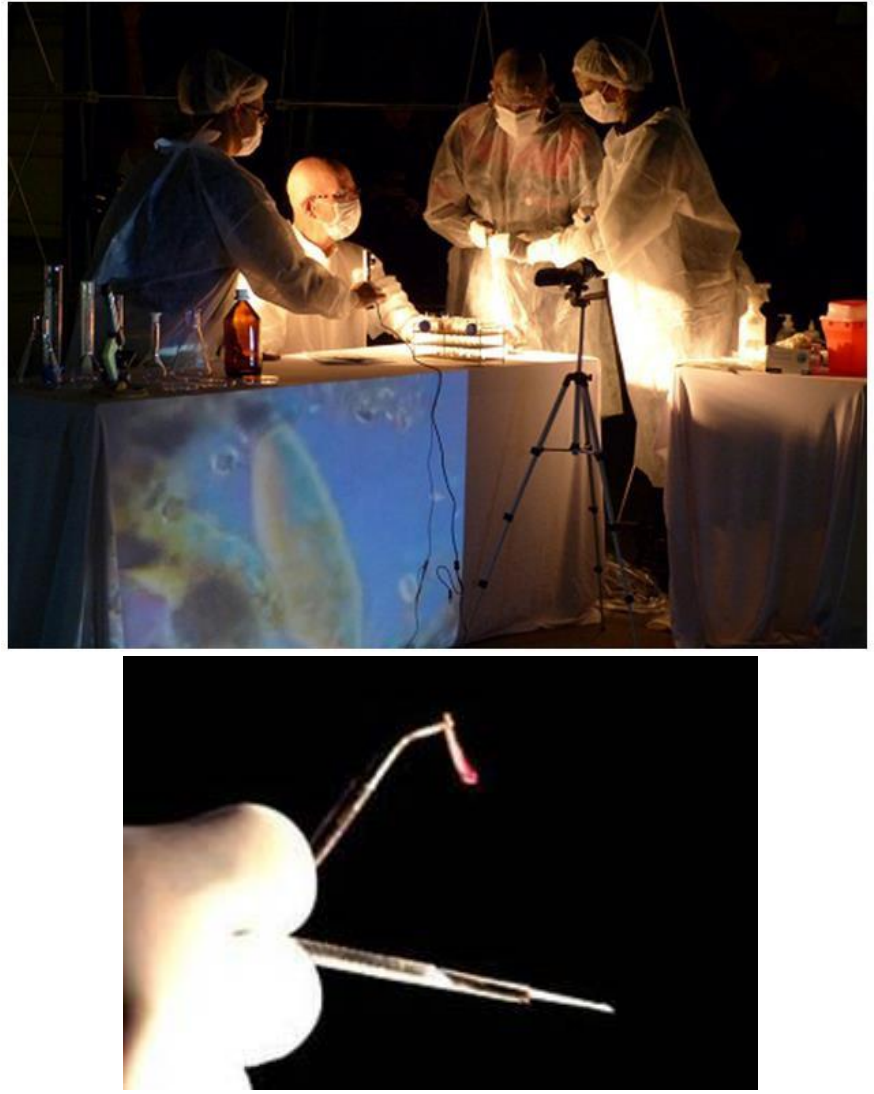

Allan Jeffs, "Ex-Sistencia".

Vista general de la

instalación con las

esculturas llevadas a la

Antártida. Museo

Antropológico de Arte

Contemporáneo de

Guayaquil, Ecuador, 2012.

Fotografía Rodolfo Kronfle

Allan Jeffs, "Ex-Sistencia". En la pared izquierda se exhiben las fotografías de las tejedoras y en la pared derecha los cultivos

bacterianos de cada una de ellas. Museo Antropológico de Arte Contemporáneo de Guayaquil, Ecuador, 2012. Fotografía Rodolfo Kronfle

Joaquín Fargas, "Bio-

Wear". Performance

realizada en el marco de la muestra Inferencias Vitales hall central Carlos Morel del Teatro San Martín, Buenos Aires, Argentina, 2012. Imagen

www.joaquinfargas.com.ar

Joaquín Fargas, "BioWear". Tejido extraído del brazo del artista durante la performance. Teatro San Martín, Buenos Aires,

Argentina, 2012. Imagen www.joaquinfargas.com.ar 
Figura 106

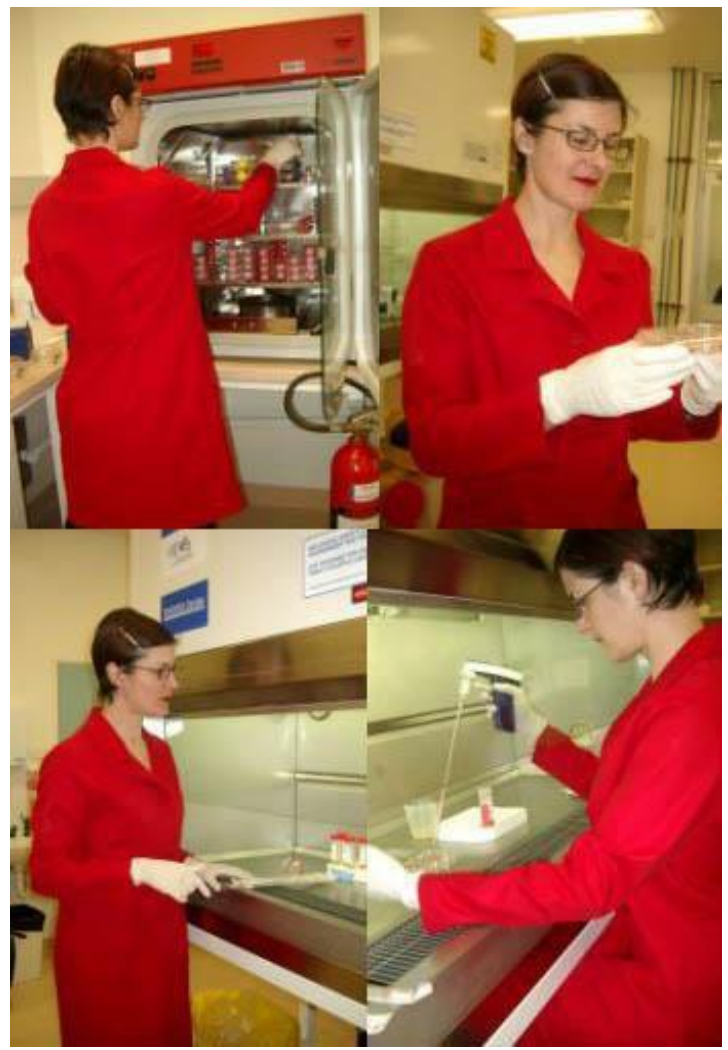

Kira O'Reilly, "Red Lab

Coat series". Imágenes de la artista en el laboratorio durante su residencia en SymbioticA, UWA, Perth, Australia, 2004. Fotografía Jennifer Willet y Shawn Bailey

Figura 107
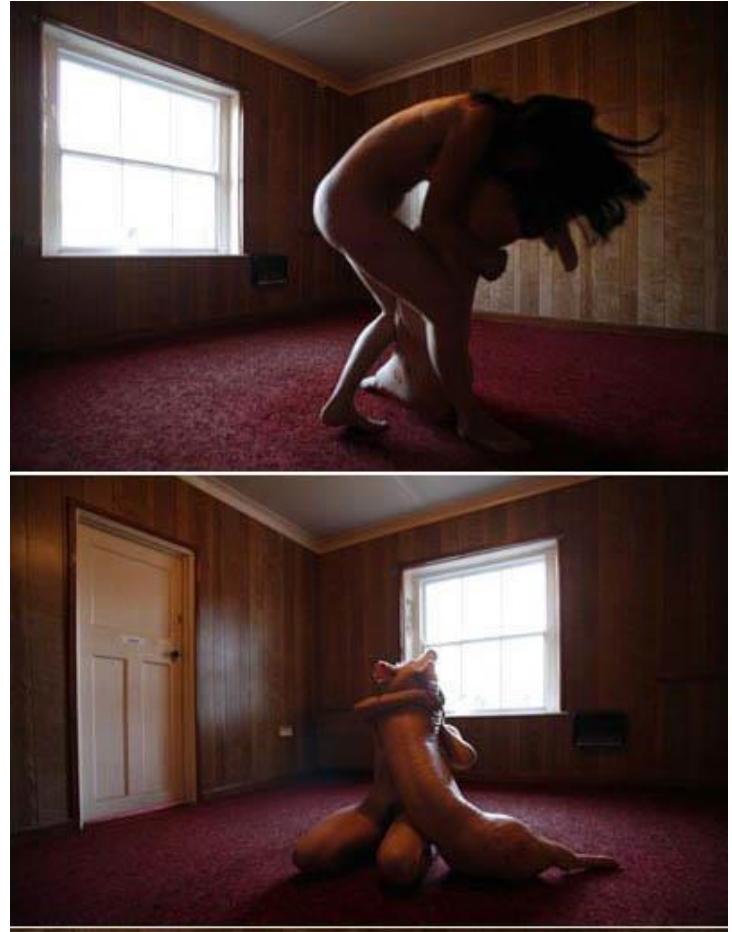

Kira O'Reilly,

"Inthewrongplaceness"

Performance realizada en el

marco de Tract Live Art,

Penzance Town Centre,

Cornwall, Inglaterra, 2006.

Fotografía Steve Tanner 
Figura 108

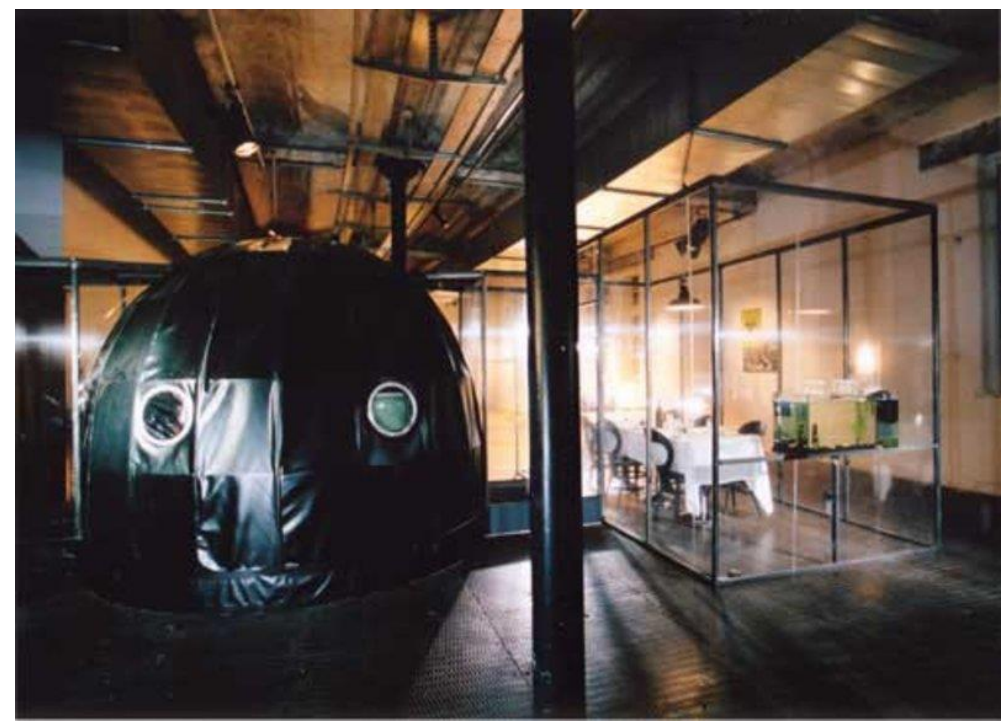

Tissue Culture \& Art

Project, "Disembodied

Cuisine". Vista general de la

instalación con el laboratorio

iglú portátil y el cuarto

ambientado para comer.

L'art Biotech, La lieu unique,

Nantes, Francia, 2003. @

TC\&A. Fotografía Axel Heise

Figura 109

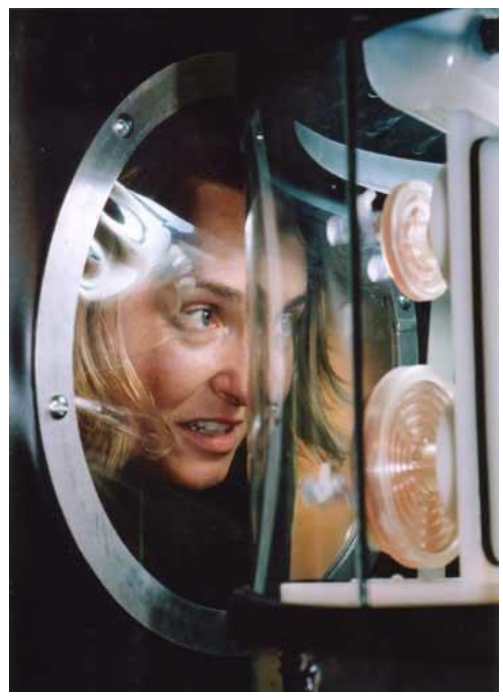

Tissue Culture \& Art

Project, "Disembodied

Cuisine". Un espectador observa el crecimiento de los

filetes cultivados. L'art

Biotech, La lieu unique,

Nantes, Francia, 2003 (c)

TC\&A. Fotografía Axel Heise

Figura 110

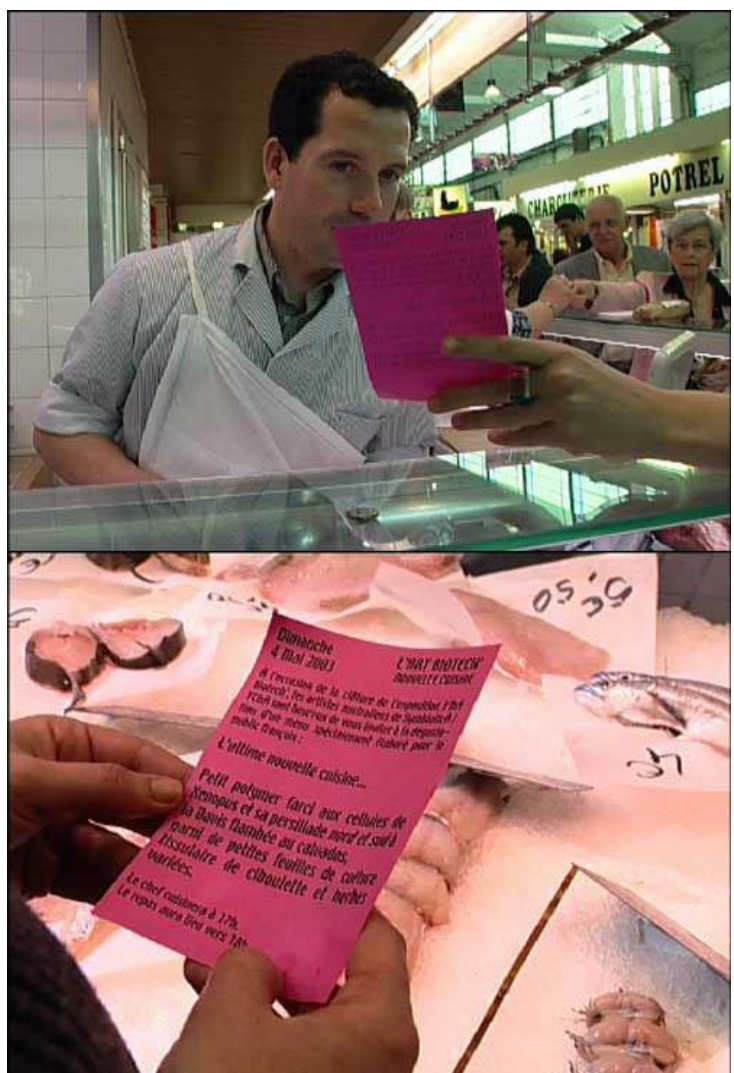

Tissue Culture \& Art

Project, "Disembodied

Cuisine". Visita al mercado

de la ciudad de Nantes,

Francia. 2003 ○ TC\&A.

Fotografía Jens Hauser 
Figura 111

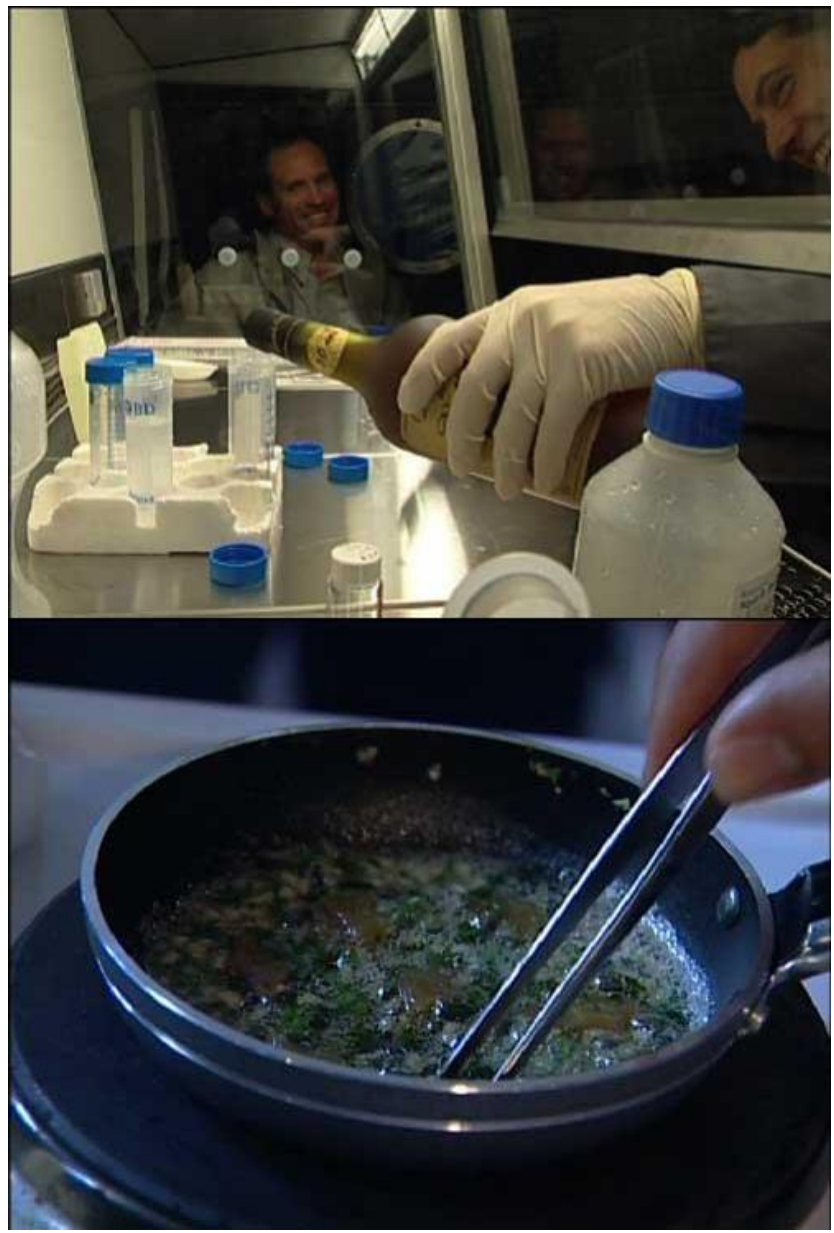

Figura 112

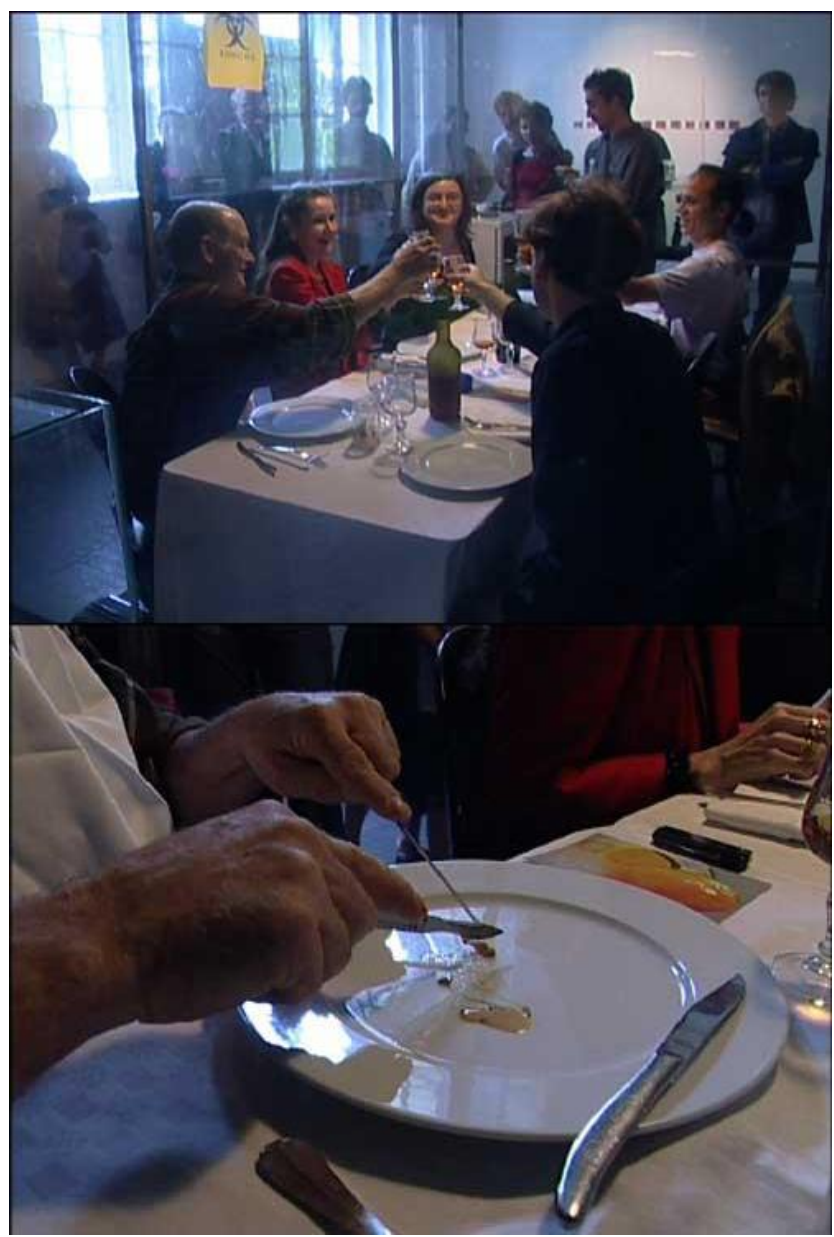

Tissue Culture \& Art Project, "Disembodied

Cuisine". Oron Catts

cocinando los filetes semi-

vivos dentro de la cabina de

bioseguridad instalada en la muestra L'art Biotech, La lieu

unique, Nantes, Francia,

2003 ๑ TC\&A. Fotografía

Jens Hauser

Tissue Culture \& Art

Project, "Disembodied

Cuisine". Espectadores

observando la performance donde los comensales cenan

los filetes cultivados. L'art

Biotech, La lieu unique,

Nantes, Francia, 2003 ๔

TC\&A. Fotografía Jens

Hauser 


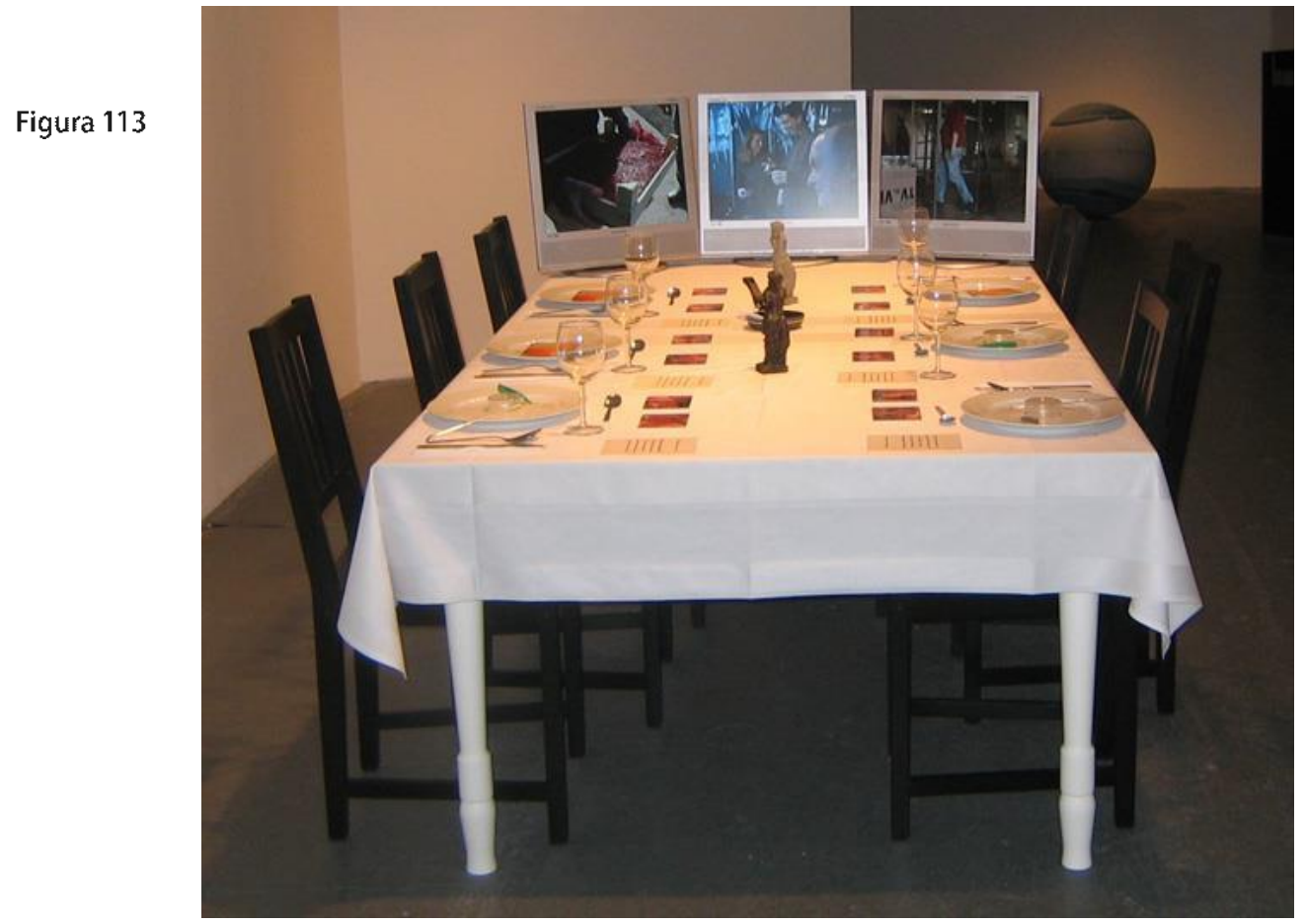

Tissue Culture \& Art

Project, "The Remains of

Disembodied Cuisine". Vista

de la instalación en la

muestra Put on your Blue

Genes, NGBK Gallery,

Berlín, Alemania, 2005. $\odot$

TC\&A.

Figura 114

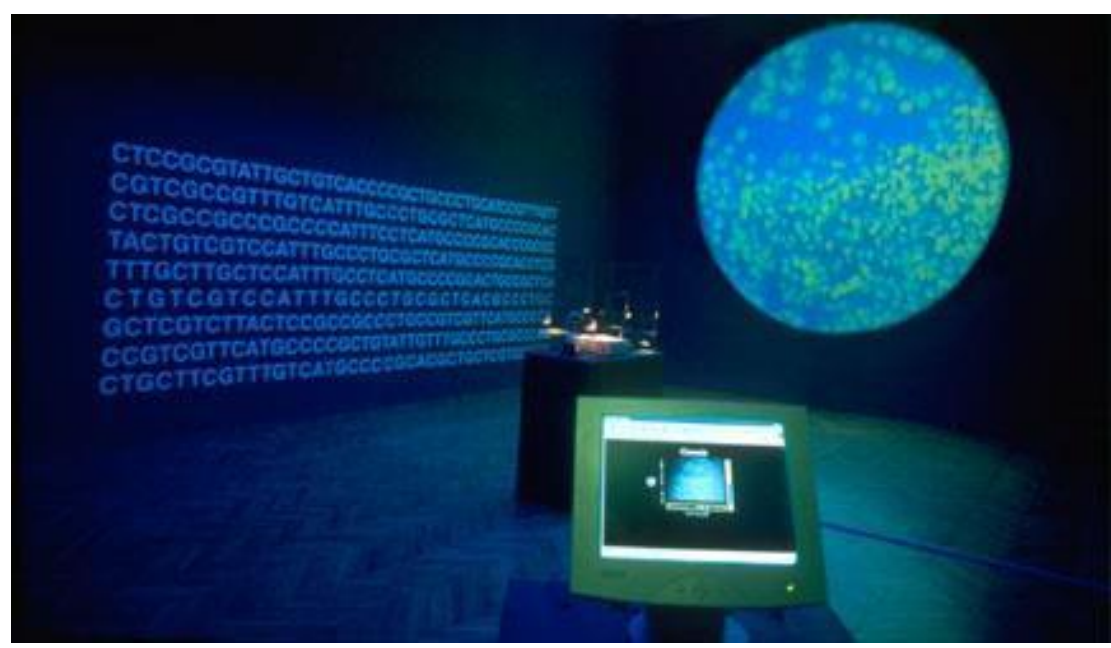

Eduardo Kac, "Genesis",

Imagen de la instalación con la computadora que permite

tanto a los espectadores

locales como remotos

interactuar con la obra. O.K.

Center for Contemporary Art,

Linz, Austria, 1999.

Fotografía Otto Saxinger

Figura 115
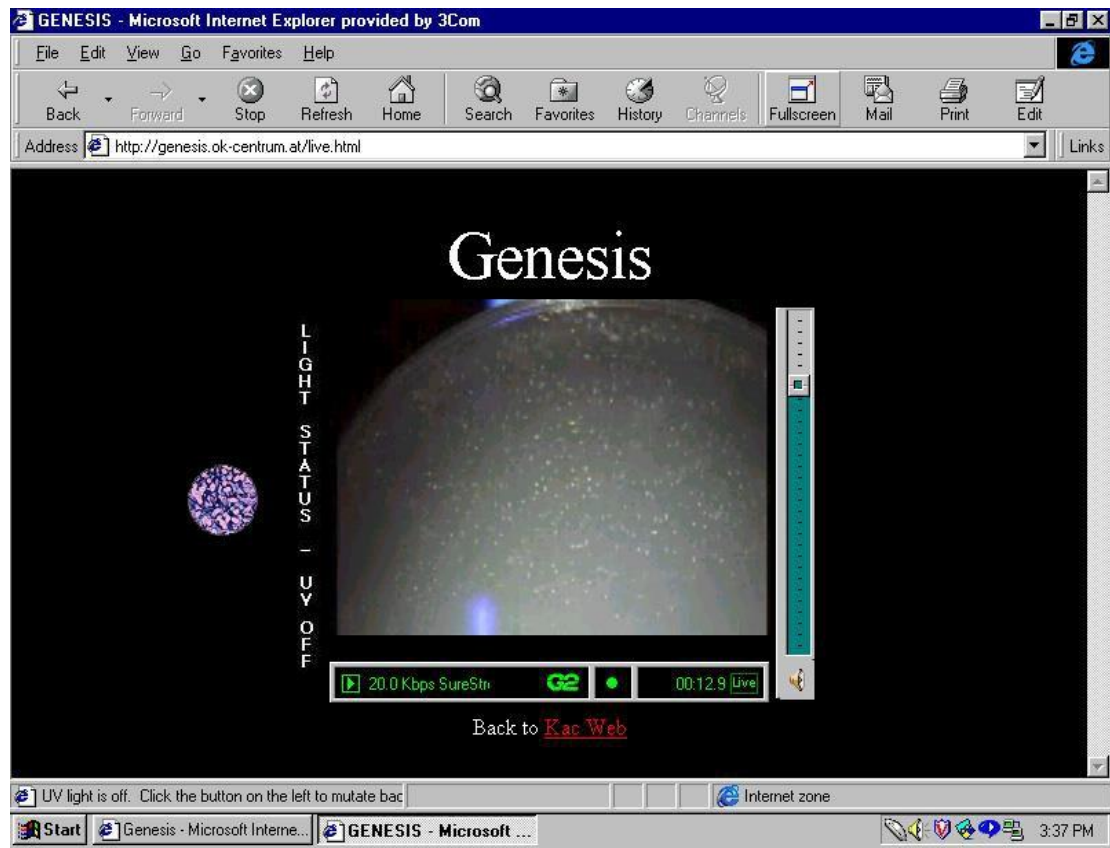

Eduardo Kac, "Genesis".

Interfaz web que permite encender la luz ultravioleta para modificar el cultivo transgénico, 1999 
Let man fiave domintion over the fish of the sea and over the fowl of the air and over every living thing that moves upor the earti

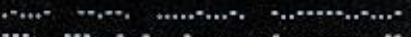

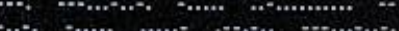

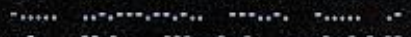
$\ldots, \cdots, \quad \cdots \ldots \cdots$

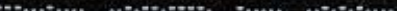
CTCCOCOTATTOCTOTCACCCCOCTOCCCTOCATCC ATGCCCCGCACCTCGCCGCCCACCCCATITCCTCAT

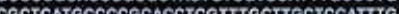
CCTCATECCCCGCACTGCCGCTCACTETCGTCCATI GCCCTECGCTCACGCCCTECGCTCGTCTTACTCCGC CGCCCTGCCGTCGITCATGCECCGCCGTCGITCAT CCECGCTGTATTGTTGCCCTGCGCCCACCTGCTICG
TTTETCATGCCCCGCACOCTOCTCOTOCCCC

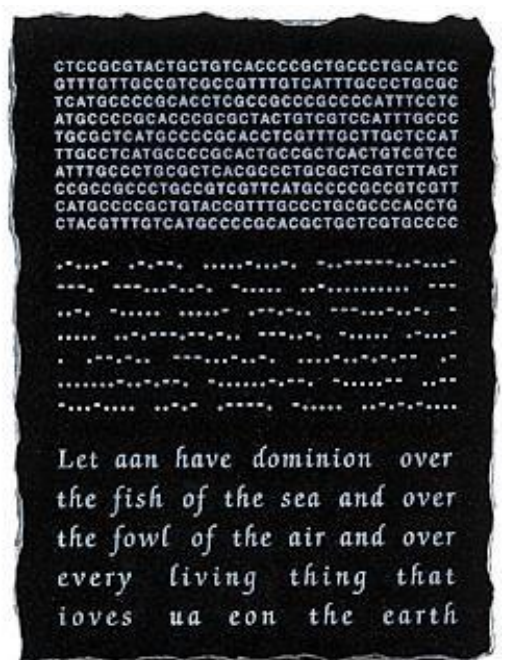

Eduardo Kac, "Genesis". A la izquierda la frase original en inglés de la biblia es pasada a código Morse y luego a código genético. A la derecha la secuencia genética modificada como consecuencia de la intervención del público es pasada a código Morse y luego al inglés. 1999.
Figura 117

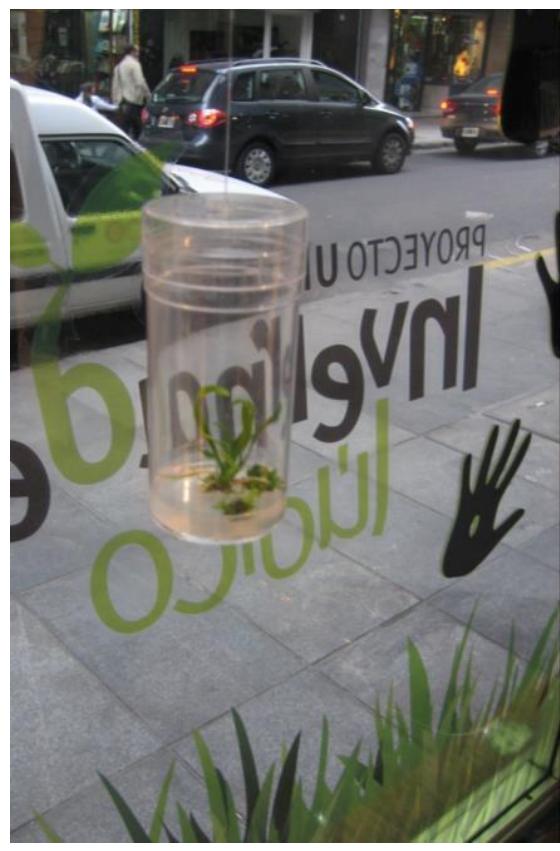

Figura 118

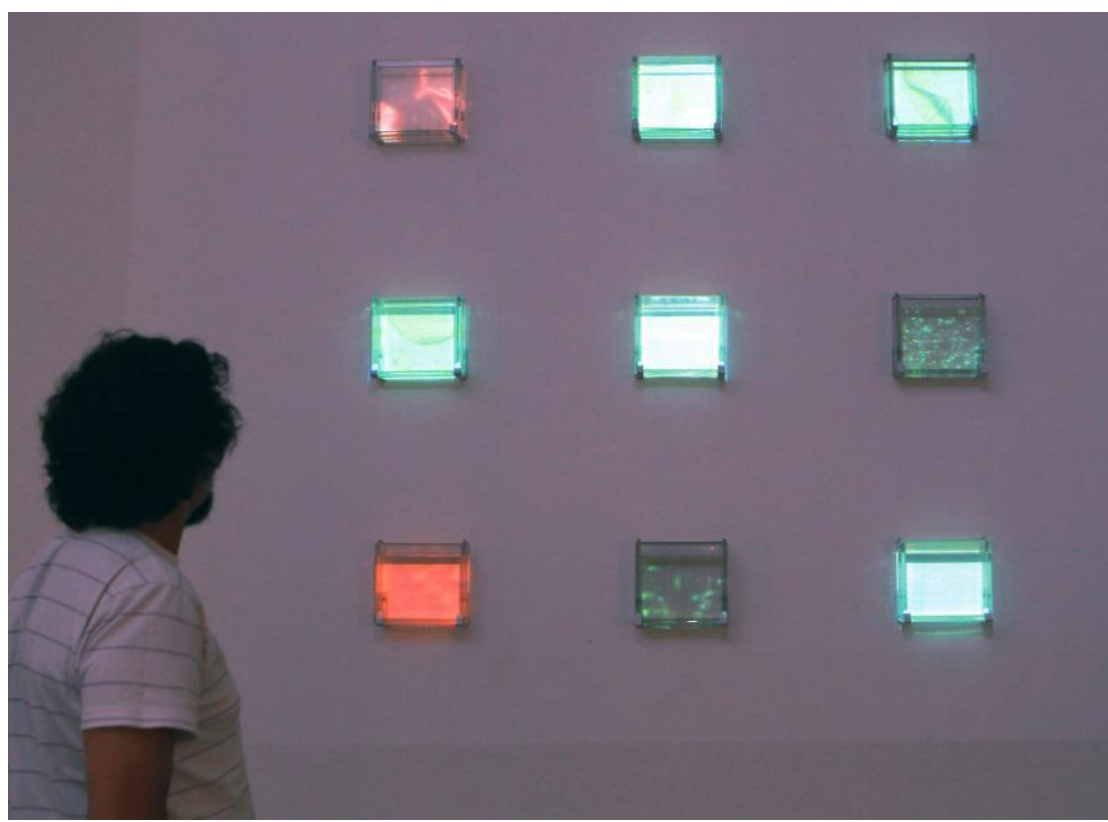

Proyecto Untitled

"Invernadero Lúdico". Detalle del lugar donde el

espectador debe apoyar su

mano para interactuar con la obra. Cultura y Media, Centro Cultural General San

Martín, Buenos Aires,

Argentina, 2008. Fotografía gentileza de Romina Flores.

Proyecto Untitled "Late". Espectador interactuando con la videoinstalación.

Extinciones, Centro Cultura Recoleta, Buenos Aires, Argentina, 2010. Fotografía gentileza de Romina Flores. 


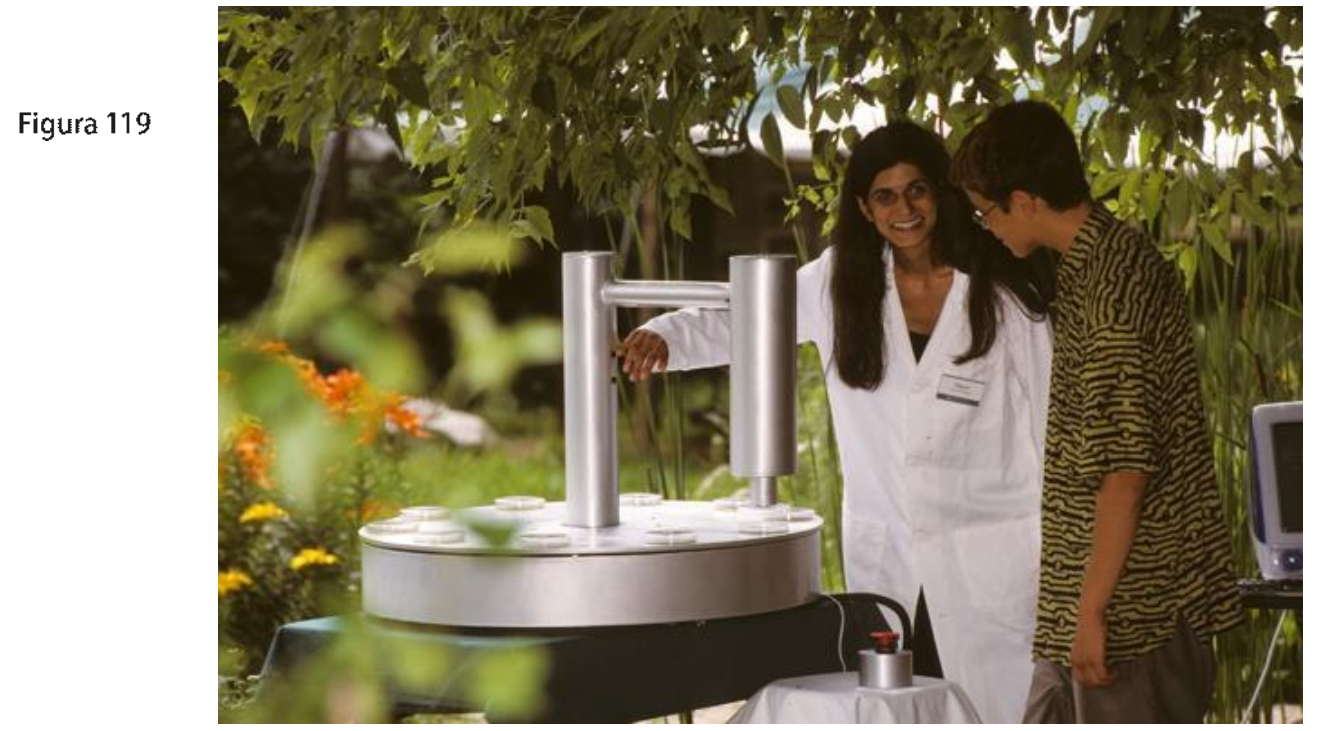

Critical Art Ensemble,

"GenTerra". Un espectador decidiendo si activar o no la máquina de liberación de bacterias transgénicas. St. Norbert Art and Cultural

Center, Winnipeg, Canadá, 2001. Imagen

http://www.critical-art.net

Figura 120

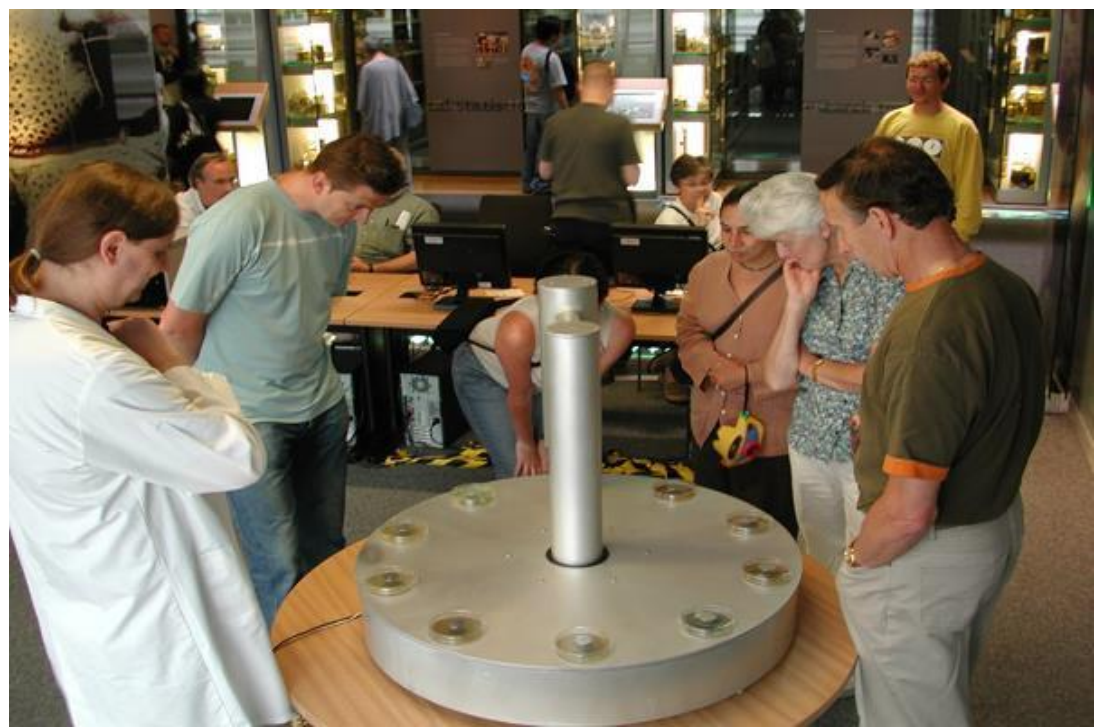

Critical Art Ensemble,

"GenTerra". Este grupo de espectadores decidieron activar la máquina lieradora de bacterias. Darwin Centre, Museum of Natural History, Londres, Inglaterra, 2003. Imagen http://www. criticalart.net

Figura 121

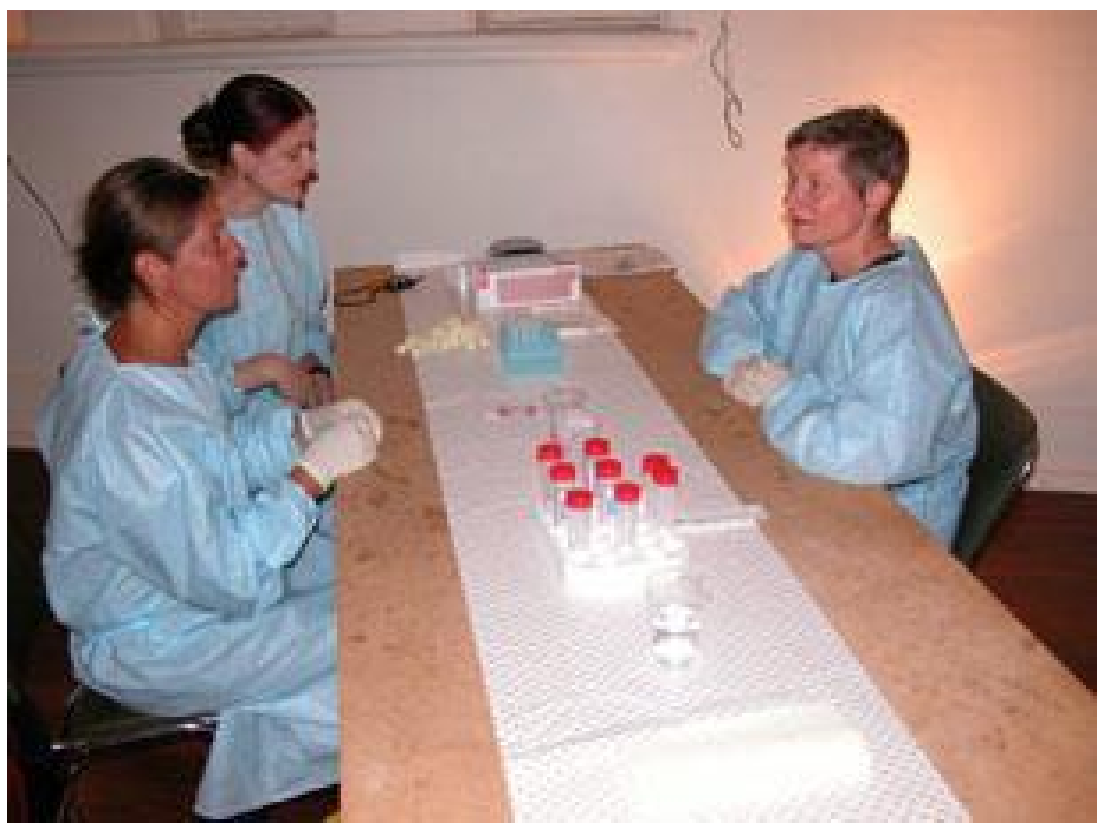

Tagny Duff,

"in-situ (in-vitro?)". La artista explicando a los

espectadores/donantes los pasos del procedimiento cientifico. Perth Institute of Contemporary Arts, Perth, Australia, 2008. 

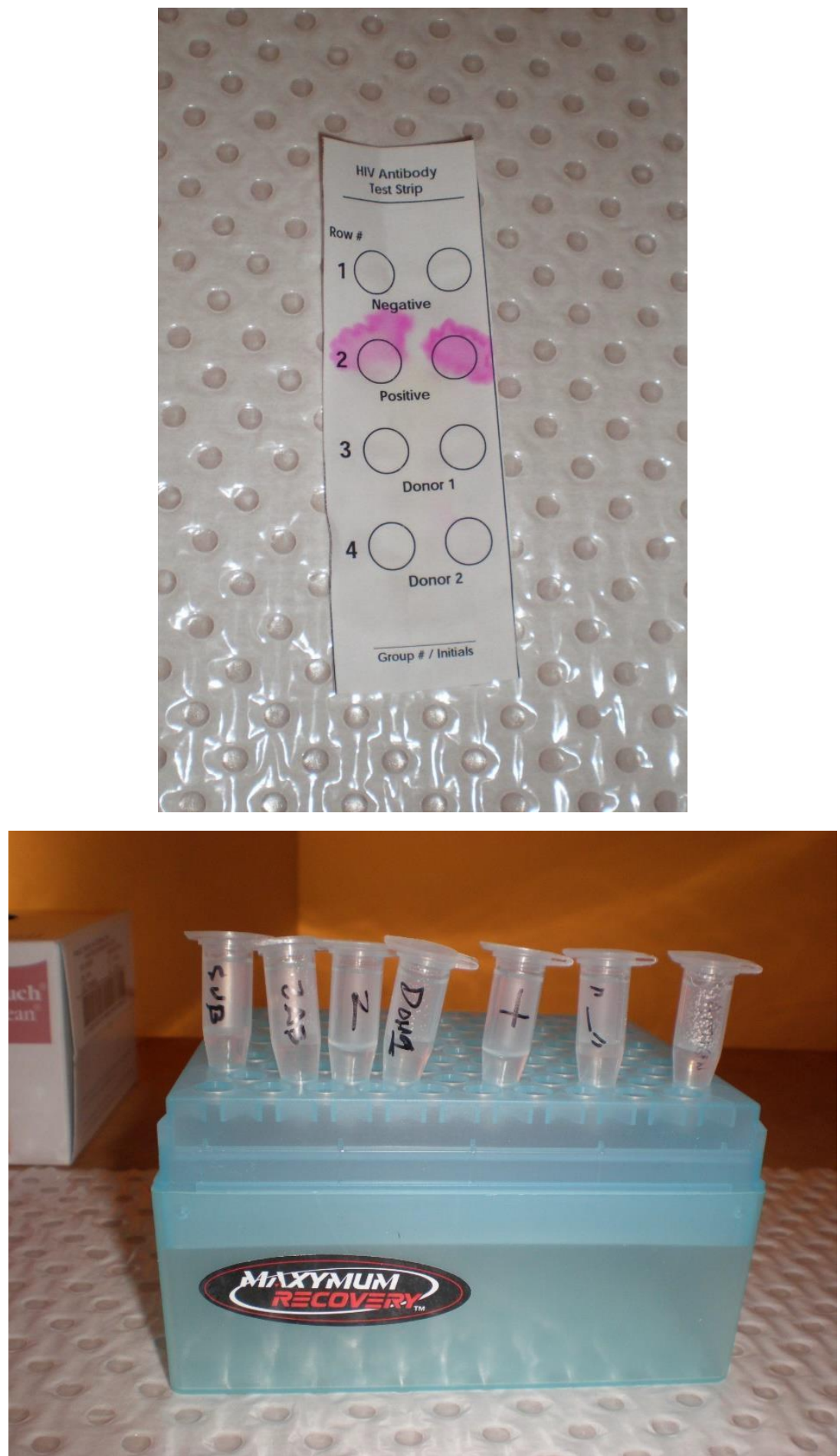

Figura 123

Figura 124

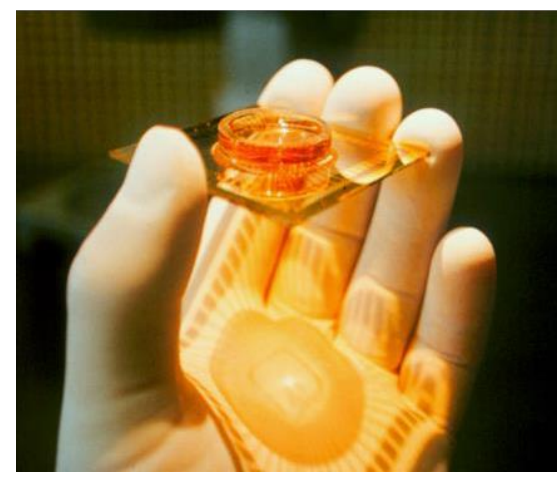

\section{Tagny Duff,}

"in-situ (in-vitro?)". Papel que registra las acciones de cada donante. Perth Institute of Contemporary Arts, Perth, Australia, 2008. Fotografía Natalia Matewecki

\section{Tagny Duff}

"in-situ (in-vitro?)". Tubos

que simulan los pasos de test Elisa. Perth Institute of Contemporary Arts, Perth, Australia, 2008. Fotografía Natalia Matewecki

\section{SymbioticA Research}

Group, "Meart - The SemiLiving Artist". A la izquierda chip MEA, a la derecha imagen microscópica del chip conteniendo el cultivo neuronal. Imagen gentileza de Guy Ben-Ary 
Figura 125

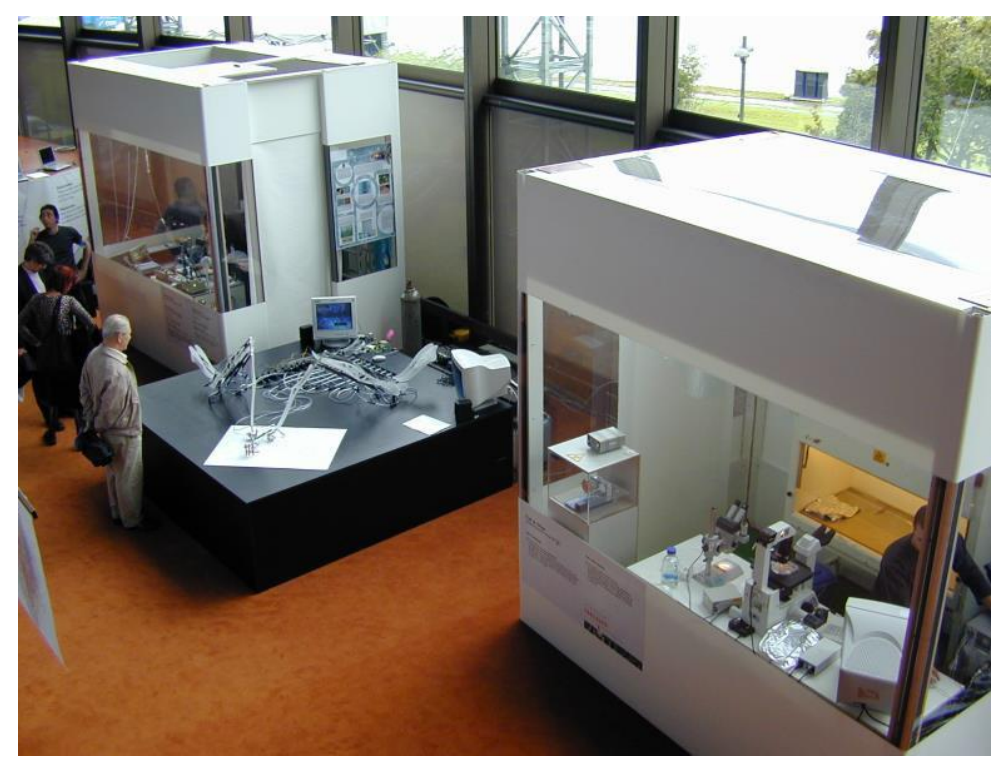

SymbioticA Research

Group, "Meart - The Semi-

Living Artist". Vista general

de la instalación con los dos laboratorios montados en

Ars Electronica, Linz,

Austria, 2001. Imagen gentileza de Guy Ben-Ary
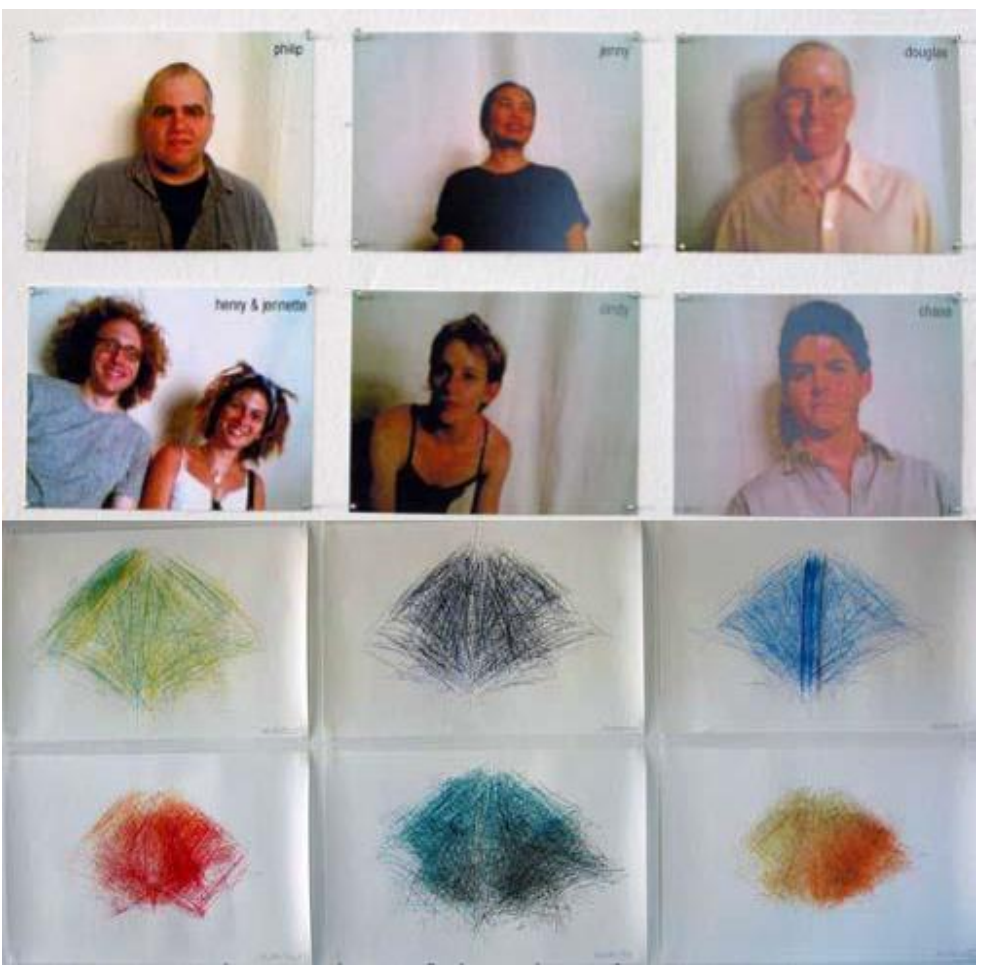

SymbioticA Research

Group, "Meart - The SemiLiving Artist". Arriba las

fotografias tomadas a los espectadores y sus

respectivos retratos debajo. ArtBots, Eyebeam Gallery, New York, Estados Unidos, 2003. Imagen gentileza de Guy Ben-Ary

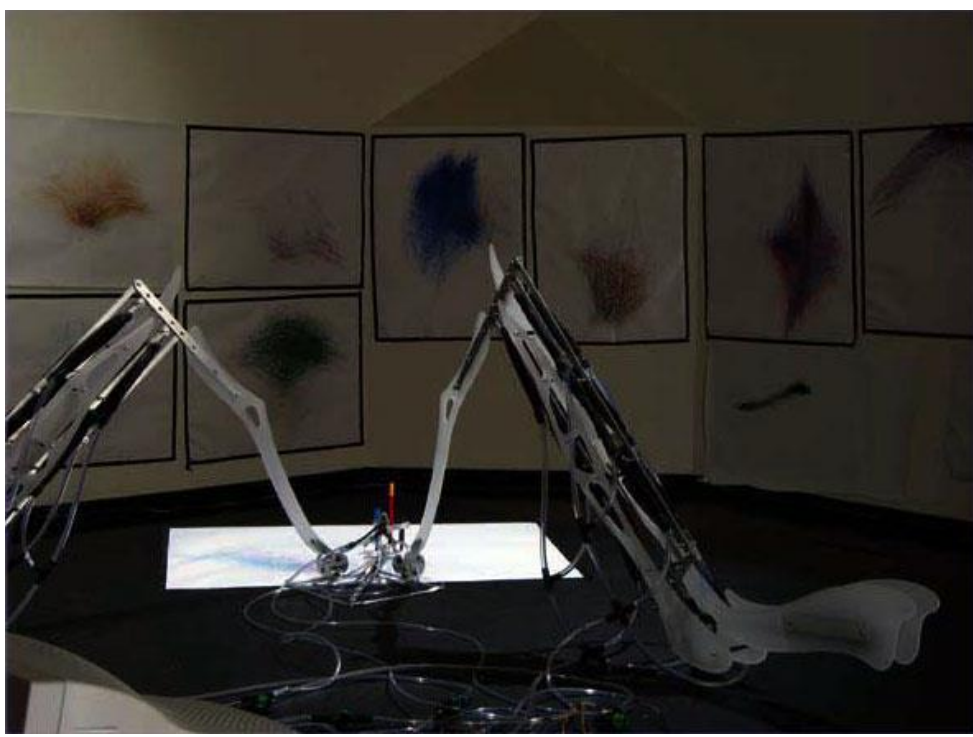

SymbioticA Research

Group, "Meart - The SemiLiving Artist". Detalle del brazo robótico dibujando. Por detrás cuelgan los retratos de cada uno de los espectadores seleccionados. Biofeel, Perth Institute of Contemporary Arts, Perth, Australia, 2002. Imagen gentileza de Guy Ben-Ary 
Figura 128

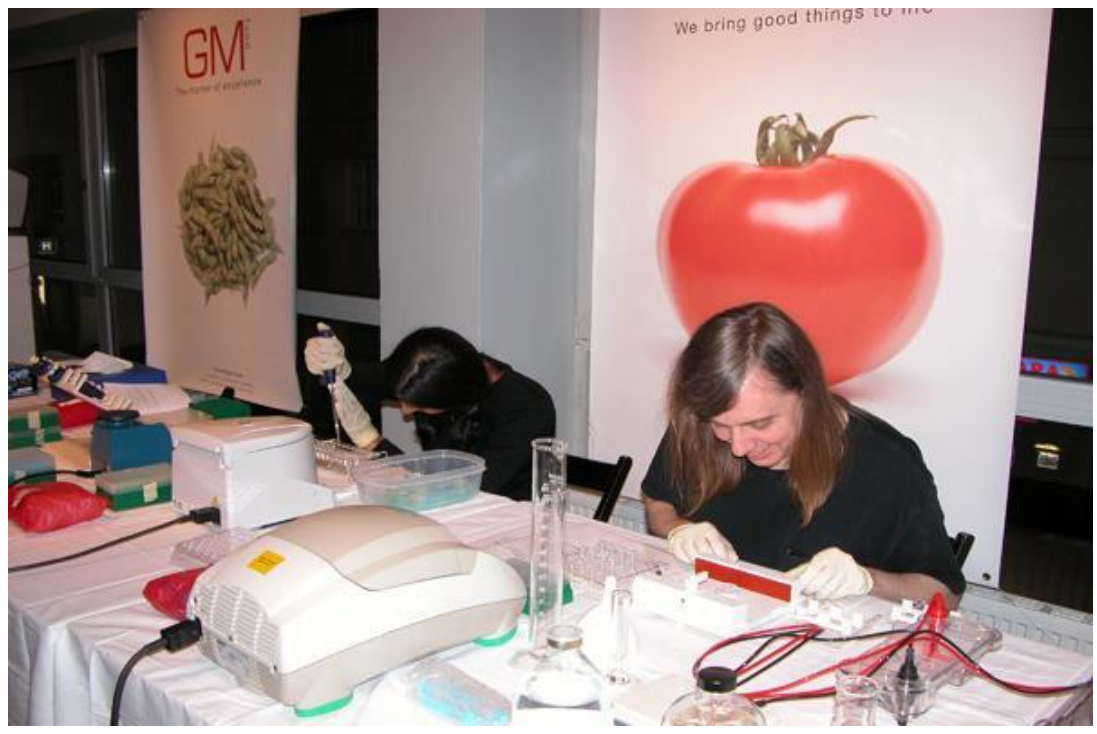

Critical Art Ensemble

"Free Range Grain"

Miembros del CAE

testeando la presencia de

marcadores de modificación

genética en la comida. ESC

Gallery, Graz, Austria, 2003.

Imagen

www.critical-art.net

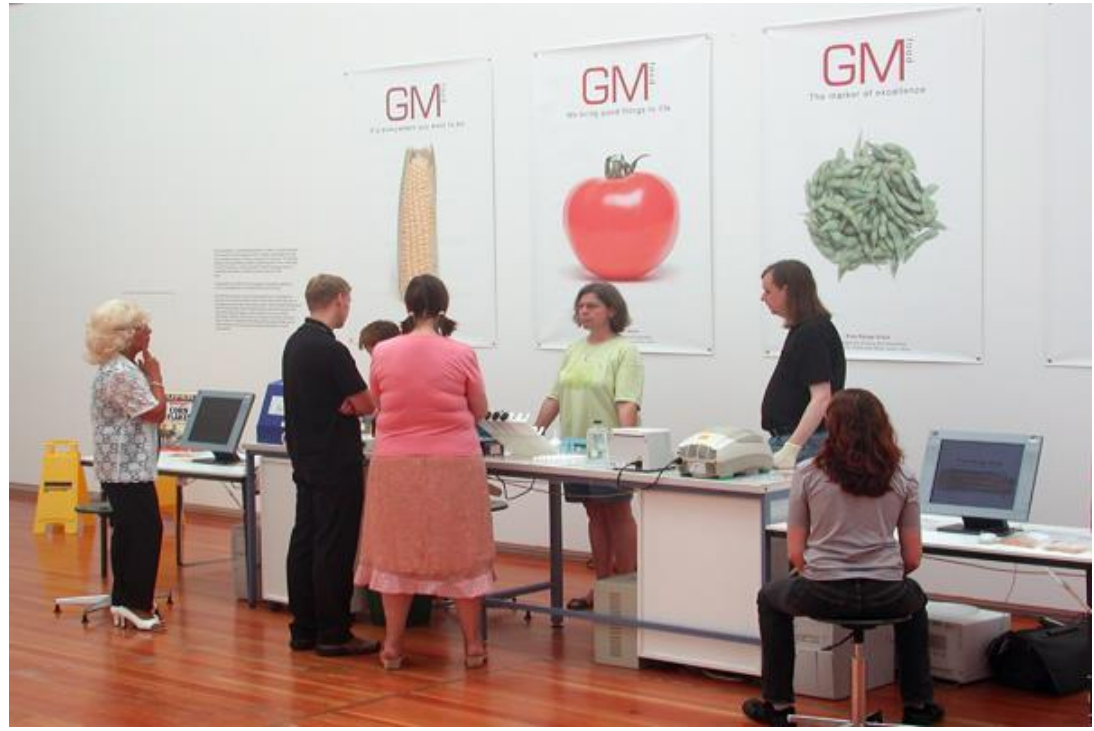

Critical Art Ensemble

"Free Range Grain".

Testeando protocolos con

los espectadores. Schirn

Kunsthalle, Frankfurt,

Alemania, 2003. Imagen

www.critical-art.net
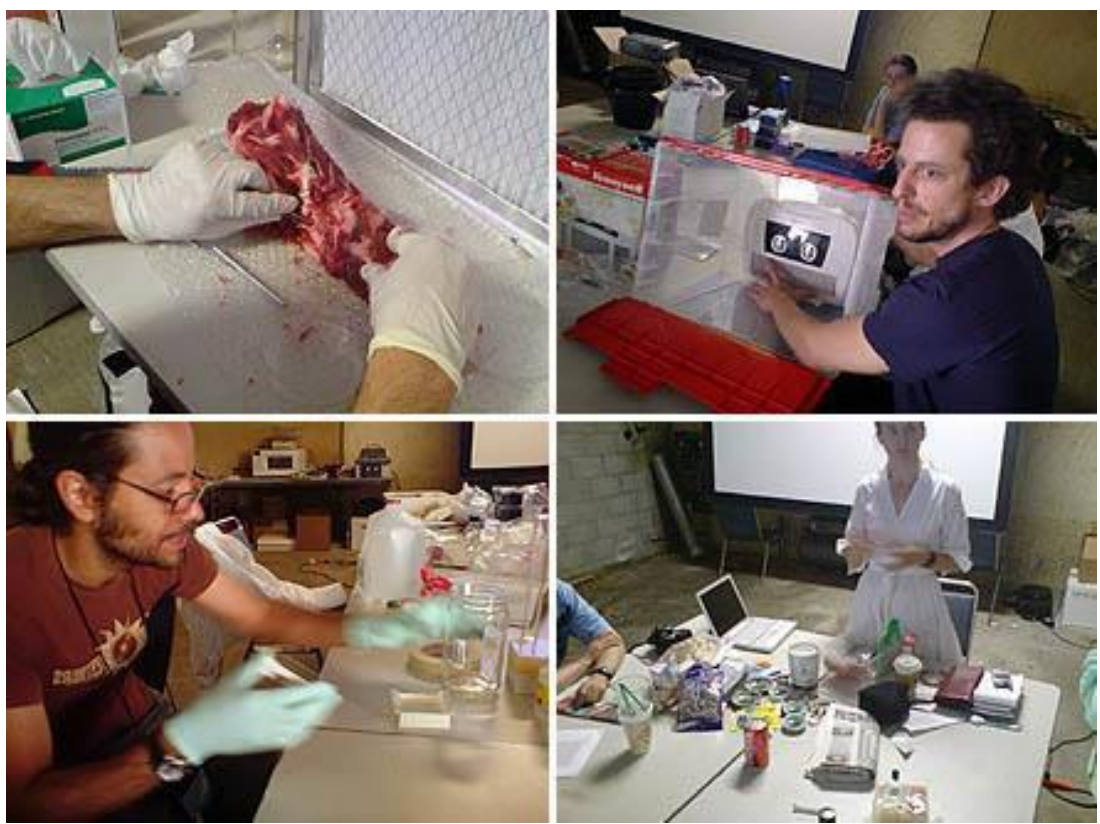

Oron Catts, Phil Ross, Paul

Vanouse y Natalie

Jeremijenko, "Wetware

Hackers". Artistas brindando

talleres al público

participante. ISEA Zero One,

San Jose, California,

Estados Unidos, 2006.

Fotografía Sascha Pohflepp 

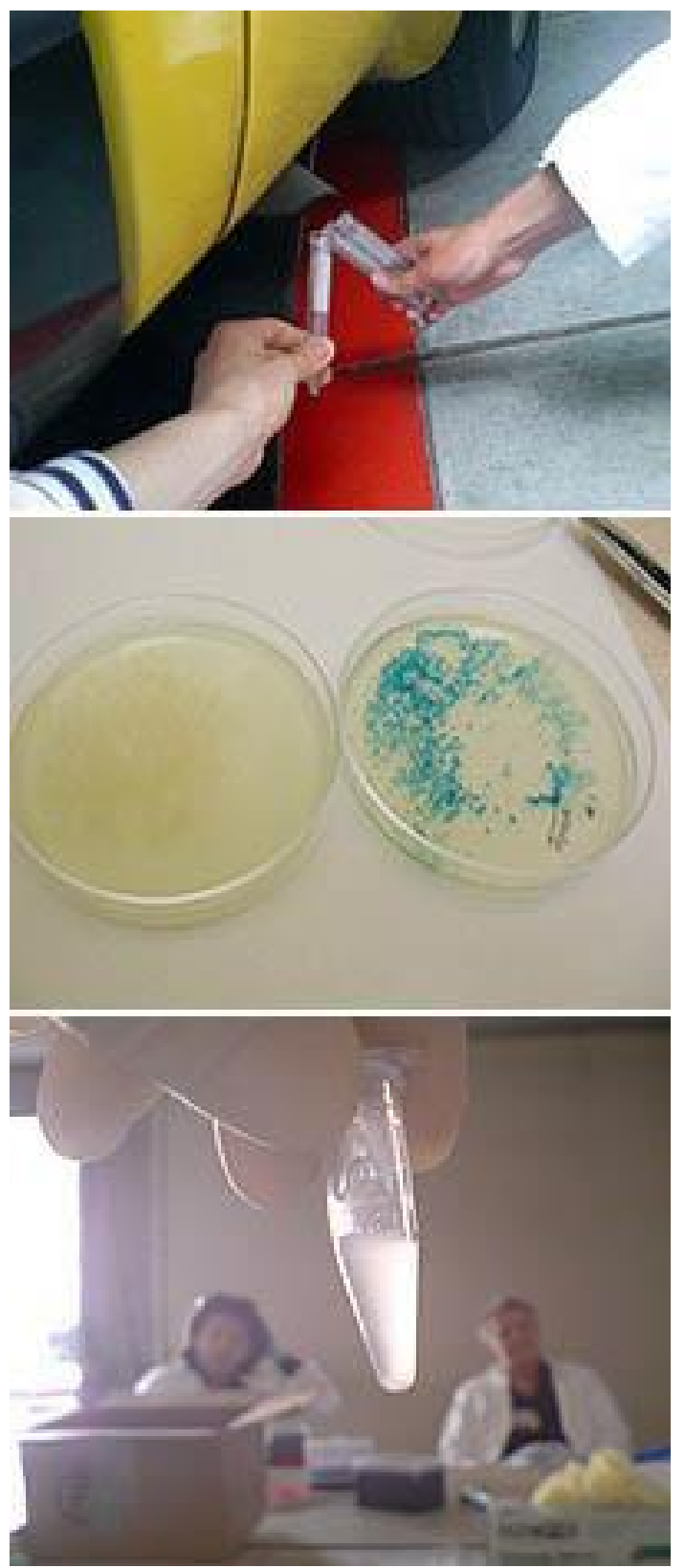

Beatriz da Costa y Tau-Mu

Yi junto a Christopher Kim,

"Experiments in Biosensing".

Examinando la

contaminación a través de

un sensor de polución

biológico basado en un tipo

de levadura. Las imágenes

fueron tomadas por una

espectadora que participaba

en el taller. ISEA Zero One,

San Jose, Estados Unidos,

2006. Fotografía Sascha

Pohflepp

Figura 132

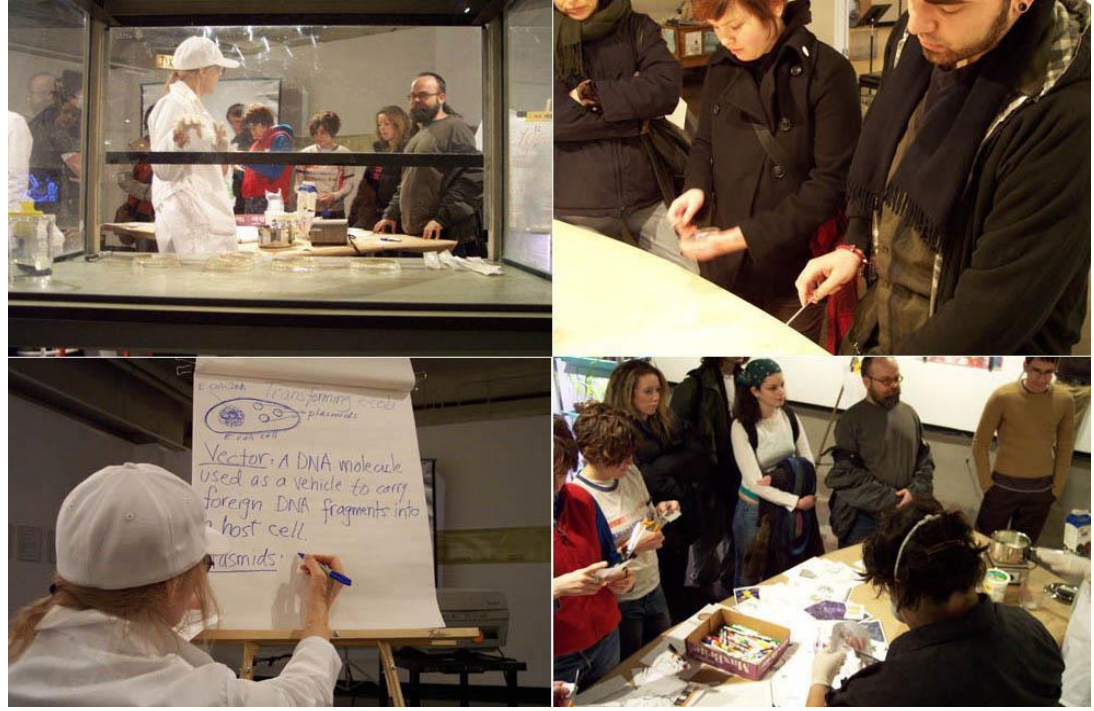

subRosa, "Epidermic! DIY

Cell Lab". Betty Rymer

Gallery, Art Institute of

Chicago, Estados Unidos,

2005. Imagen Soft Power

(ㄷ)(1)(3) 


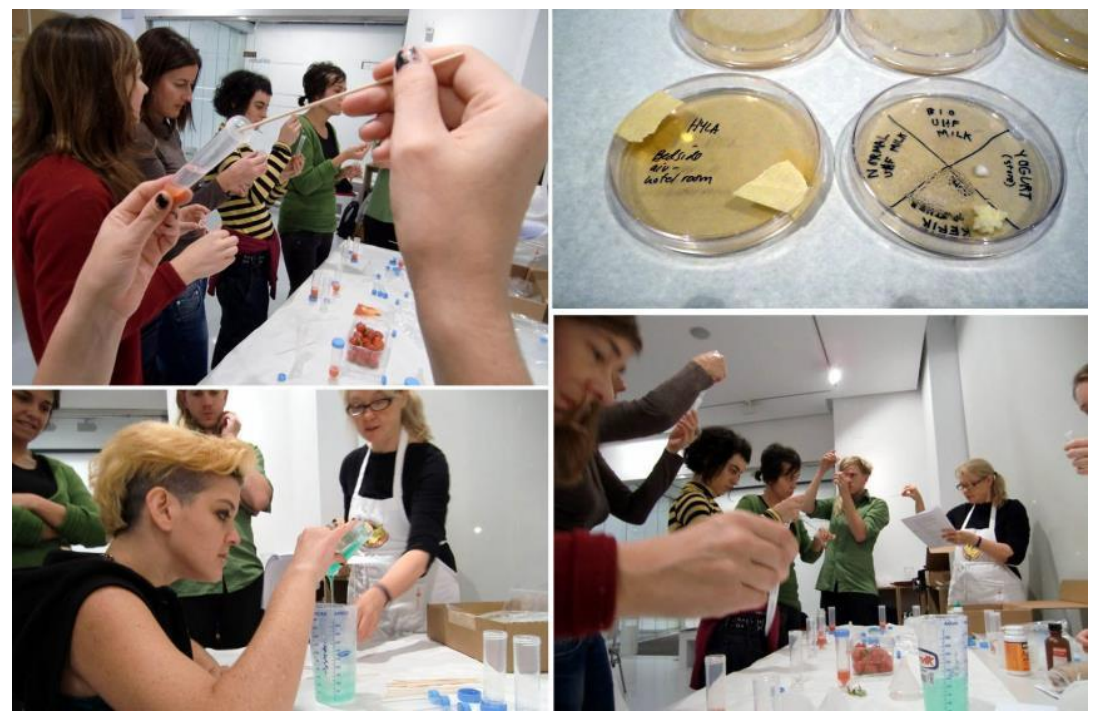

subRosa, "DIY Bodies

Unlimited!". Público

participando del taller-

laboratorio de ciencia. Sala

Rekalde, Bilbao, España

2010. Imagen Soft Power 다)(잉

Figura 134
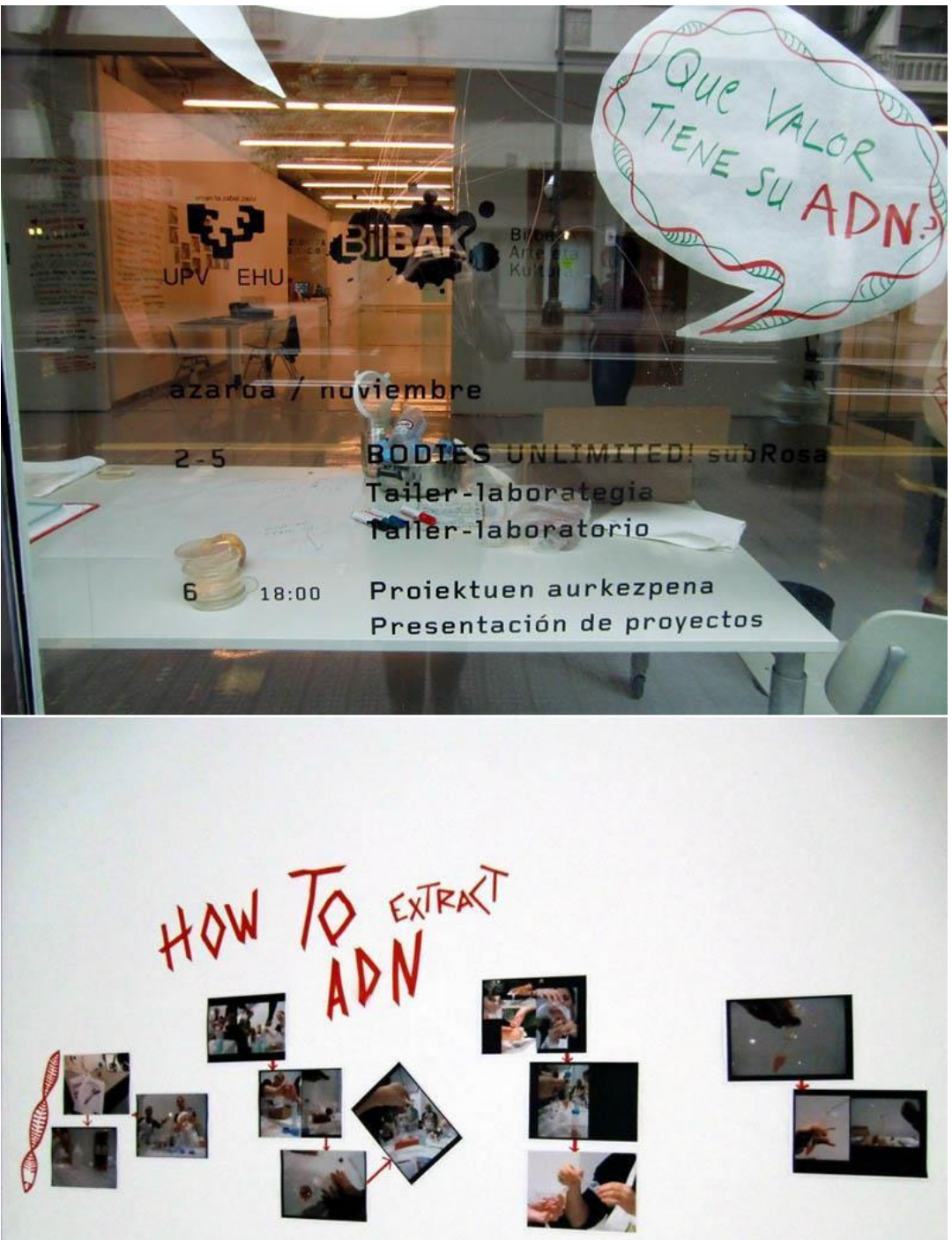

subRosa, "DIY Bodies

Unlimited!". Muestra

realizada a partir de los resultados del taller-

laboratorio, en el marco de Soft Power II. Sala Rekalde Bilbao, España, 2010. Imagen Soft Power (ㄷ)(1) $\$(0)$ 